\title{
Uppermost Ordovician (upper Katian-Hirnantian) graptolites of north-central Nevada, U.S.A.
}

\author{
Petr Štorch, Charles E. Mitchell, Stanley C. Finney \& Michael J. Melchin
}

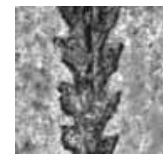

Forty-three graptolite species belonging to fifteen genera are described from the upper Katian ornatus and pacificus biozones and Hirnantian extraordinarius and persculptus biozones of Vinini Creek and Martin Ridge reference sections of north-central Nevada. Approximately half of the species described have not been previously recorded from Nevada, six species are left in open nomenclature. Infraorder Neograptina and Styracograptus gen. nov. are erected. The maximum graptolite diversity is in organic-rich black shale in the lower part of the pacificus Biozone in the Vinini Formation. Species diversity decreased abruptly at the top of the Diceratograptus mirus Subzone, recognized herein in the upper part of the pacificus Biozone. Faunal turnover reached a peak in the lower part of early Hirnantian extraordinarius Biozone where long-dominant Ordovician clades (diplograptines) are rapidly replaced by normalograptids (Neograptina), presumably evolved in, and invading from, a less-temperate higher latitude. Eight late Katian diplograptine species recur in the upper part of the extraordinarius Biozone but, in contrast to their former abundance, are present there only as very rare individuals. Even more unusually, eight diplograptine species (members of Dicellograptus, Anticostia, Rectograptus, Paraorthograptus, Phormograptus, Styracograptus and Appendispinograptus) also reappear in the uppermost part of the Vinini Creek section, well into the persculptus Biozone (which is topped by a prominent stratigraphic unconformity). These occurrences record a complex extinction pattern among graptolites that involved a radical but extended ecological reorganization rather than a synchronous global collapse of the pre-glacial ecosystem. The biozonation applied in the Nevadan sections correlates well with those established in the Yangtze Platform of China, southern Kazakhstan, north-eastern Siberia and Northern Canada. - Key words: graptolite, Ordovician, Katian, Hirnantian, mass extinction, biostratigraphy, Nevada.

ŠToRCh, P., Mitchell, C.E., FinNEY, S.C. \& Melchin, M.J. 2011. Uppermost Ordovician (upper Katian-Hirnantian) graptolites of north-central Nevada, U.S.A. Bulletin of Geosciences 86(2), 301-386 (28 figures, 26 tables). Czech Geological Survey, Prague. ISSN 1214-1119. Manuscript received March 17, 2011; accepted in revised form May 31, 2011; published online June 17, 2011; issued June 20, 2011.

Petr S̆torch, Institute of Geology v.v.i., Academy of Sciences of the Czech Republic, 16500 Praha 6, Czech Republic; storch@gli.cas.cz • Charles E. Mitchell, Department of Geology, State University of New York at Buffalo, Buffalo, NY 14260, USA; cem@geology.buffalo.edu - Stanley C. Finney, Department of Geological Sciences, California State University Long Beach, CA 90840, USA; scfinney@csulb.edu・Michael J. Melchin, Department of Earth Sciences, St. Francis Xavier University, Antigonish, NS B2G 2V5, Canada; mmelchin@stfx.ca

Abundant graptolites from the Vinini Formation in the Roberts Mountains of north-central Nevada (Fig. 1) record the late Ordovician peak of species abundance and taxonomic diversity of Graptoloidea, and the descent from that zenith to the nadir of the Hirnantian Mass Extinction - an episode that may have been second only to the great end-Permian events in its effect on biotic richness (Bambach et al. 2004, but see Alroy et al. 2008, for a different assessment). Because of the wide geographic distribution, rapid evolutionary turnover, and planktic habit of graptolites, specieslevel data are readily available for investigating the Late Ordovician events, and the faunas described here play a central role in that effort. As a result of extensive new collections and comparison with similar faunas that we have examined elsewhere, we record here 26 taxa that are new to the region and substantially revise the ranges of others. We also take this opportunity to update the generic and higher level systematics of the Late Ordovician Graptoloidea to reflect the results of recent phylogenetic analyses.

The outstanding graptolite succession of the uppermost Vinini Formation ranges from the uppermost Katian $D i$ cellograptus ornatus Biozone to the Hirnantian Normalograptus persculptus Biozone. In addition, the Hanson Creek Formation in the nearby Monitor Range has a moreor-less coeval graptolite succession that includes very well preserved graptolites in the Dicellograptus ornatus and Paraorthograptus pacificus biozones. Uppermost Ordovician graptolites in the Roberts Mountains were first reported by Merriam \& Anderson (1942), and those of the Monitor Range by Merriam (1963). In a study of Ordovician 


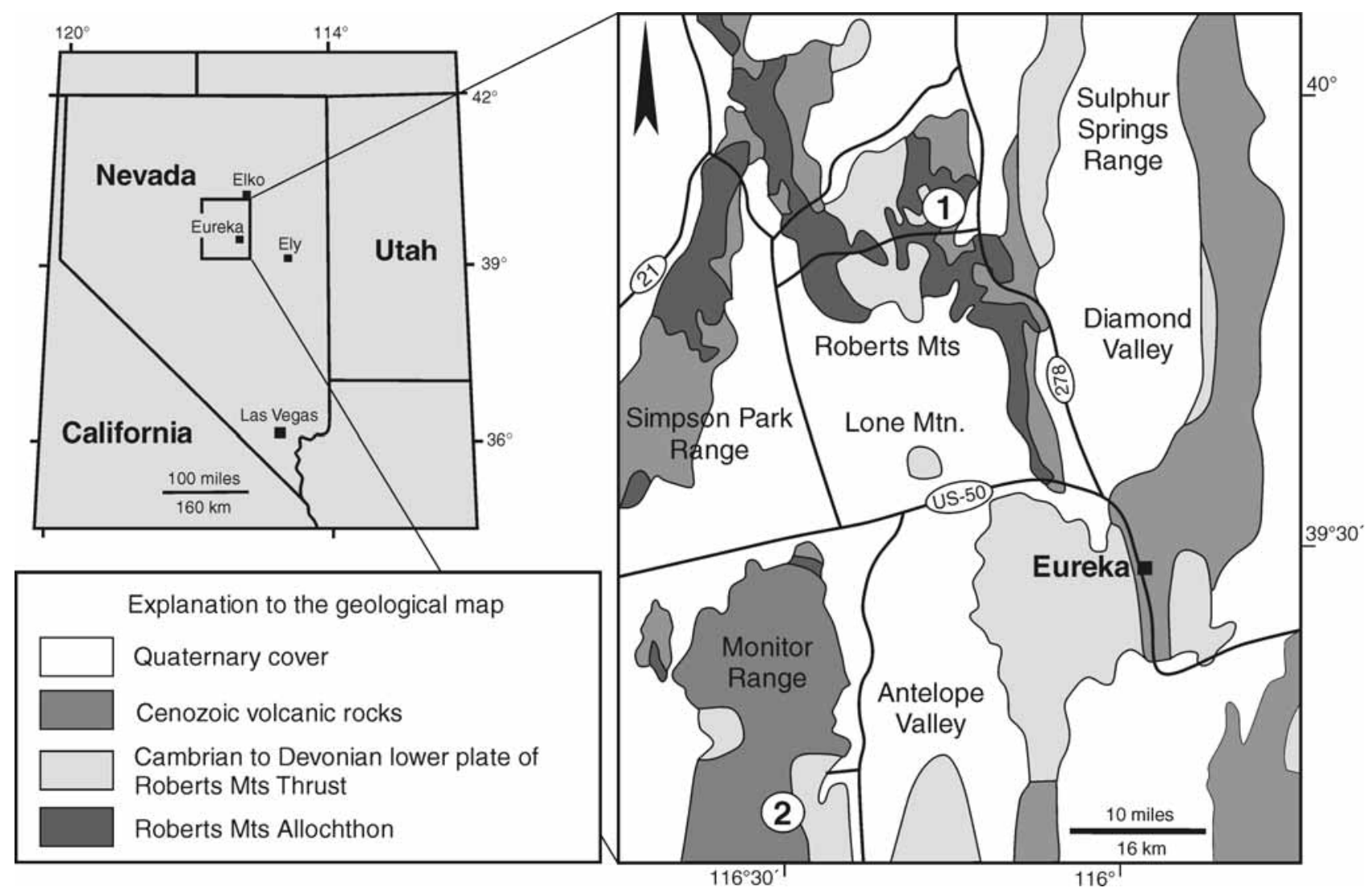

Figure 1. Map showing location of Vinini Creek section in Roberts Mountains (1) and of Martin Ridge section in Monitor Range (2) in north-central Nevada.

graptolites from the Great Basin in the collections of the U.S. Geological Survey, Ross \& Berry (1963) provided extensive faunal lists of uppermost Ordovician graptolites from these areas, and described and illustrated many species. These early studies were based on collections acquired during geologic mapping. They were not from measured sections, and generally were small samples taken from scree. In the late 1980s, Stan Finney began a systematic study of the graptolite biostratigraphy of the Vinini Formation, sampling from measured sections (Finney \& Perry 1991), and also collected the graptolites of the Hanson Creek Formation in a measured section on Martin Ridge (Fig. 1) in the Monitor Range (Dworian 1990). This work revealed the potential of sections at Vinini Creek in the Roberts Mountains and at Martin Ridge for an integrated, multi-disciplinary study of the Late Ordovician mass extinction (Finney et al. 1995).

Following excavation by bulldozer that completely exposed the Vinini Creek section (Fig. 2), the uppermost Vinini Formation was carefully measured, described in detail, and sampled extensively and systematically for graptolite, conodont, and chitinozoan biostratigraphy and for carbon isotope stratigraphy. The Martin Ridge section was measured, described, and sampled similarly. Some results and conclusions of these studies were published in Finney et al. (1997, 1999, 2007), Ripperdan et al. (1998), Berry \& Finney (1999), and Finney \& Berry (1999), however the graptolite faunas were not illustrated or described previously. Nevertheless, the graptolite succession in the Vinini Creek section was demonstrated to be one of the best records worldwide of the Late Ordovician mass extinction. Realizing its potential as a data source for quantitatively analyzing faunal dynamics before and during the mass extinction, Charles Mitchell organized a team of graptolite specialists, geochemists, and a mathematician to sample the Vinini Creek section in a quantitatively more rigorous fashion and to carry out comparative studies on other uppermost Ordovician successions in the Yukon, in the Yangtze Platform of China, and the Bohemian succession (with Štorch). As part of this project, Petr Štorch undertook a monographic study of Finney's graptolite collections from the Vinini Creek and Martin Ridge sections, supplementing it with the examination of the samples from the Mitchell project. Final identifications and systematics followed upon extensive collaboration among the present authors.

The graptolite collections from the Vinini Creek and Martin Ridge sections provide an unparalleled opportunity 
to study the Late Ordovician mass extinction. The Vinini Creek section in particular provides a most complete and expanded succession through the extinction interval. Samples are closely spaced, and many are large with abundant specimens and high diversity. Although generally flattened in mudstones and with some tectonic distortion, specimens are well preserved. The deep-marine and outer-shelf facies successions in the Vinini Creek and Martin Ridge sections, respectively, allow sea-level changes to be well documented. In addition, the graptolite successions can be integrated with conodont and chitinozoan biostratigraphy and with carbon isotope stratigraphy (see Finney et al. 1999). Furthermore, graptolites of correlative sections in the Yangtze Platform of China already have been described and illustrated and recently revised (Mu et al. 1993; Chen et al. 2000, 2005a), and work is well underway on the graptolites from an important section in the Yukon (Loxton pers. comm. 2010). Accordingly, this monographic treatment of the graptolites of the Vinini Creek and Martin Ridge sections is most important and most opportune.

\section{Geologic setting and locality descriptions}

The Vinini and Hanson Creek formations are within stratigraphic successions of the upper and lower plates, respectively, of the Roberts Mountains Thrust, a major regional structure (500+ km along strike) developed during the Late Devonian-Early Mississippian Antler Orogeny. The upper plate, the Roberts Mountains Allochthon, is composed of an intensely deformed, several thousand meters thick, Cambrian-Devonian succession of hemipelagic shale and chert, turbiditic sandstone, deep-water limestone, and greenstone. It was deposited on the lower slope, rise, and ocean plain adjacent to the western margin of Laurentia (Finney \& Perry 1991; Finney et al. 1993, 2000). The uppermost Cambrian to uppermost Ordovician Vinini Formation composes most of the allochthon in the Roberts Mountains, Eureka County, Nevada. There it was defined on outcrops throughout the Roberts Mountains, with a type section on Vinini Creek (Fig. 1). The Vinini Formation is divisible into a lower member of greenstone, deep-water limestone, black shale, and a 2-km thick submarine fan complex and an upper member largely of shale, siliceous mudstone, chert, occasional quartz sandstone beds, and deep-water limestone (lime mudstone) at the top. The lower, autochthonous plate of the Roberts Mountains Thrust is composed of a thick succession of richly fossiliferous, Cambrian to Upper Devonian, shelfal carbonate with occasional sandstone and shale. The Hanson Creek Formation, composed of $140 \mathrm{~m}$ of limestone, cherty limestone, and dolostone at Martin Ridge in the Monitor Range, Eureka County, Nevada (Fig. 1), correlates with the Katian and Hirnantian stages of the Upper Ordovician Series. It was deposited in a basin on the outer margin of the western shelf of Laurentia (Dunham 1977). To the north, south and east, its facies change to those of more shallow-water; it thins - being cut out in part by disconformities - and it becomes dolomitic.

The Vinini Formation in the Roberts Mountains was deposited $\sim 200 \mathrm{~km}$ to the west of the stratigraphic section of the Hanson Creek Formation in the Monitor Range, and along with other basinal strata of the allochthon, was displaced far eastward onto the autochthonous, carbonate platform succession. As a result of this structural juxtaposition, the Vinini Creek section, which exposes the uppermost Vinini Formation, is located NNE of the Martin Ridge section containing strata of the Hanson Creek Formation. The Vinini Formation is regionally intensely deformed although locally, as in the section at Vinini Creek, significant stratigraphic intervals are coherent and allow for detailed and systematic description and sampling.

The Vinini Creek section (Figs 2, 3) is within a bulldozer-excavated trench (N 39 $52^{\prime} 18.9^{\prime \prime}$, W $116^{\circ} 14^{\prime} 05.5^{\prime \prime}$ ) that exposes the upper $\sim 30$ meters of the Vinini Formation (uppermost $28.7 \mathrm{~m}$ measured) and several tens of meters of the overlying Silurian Elder Sandstone. The uppermost Vinini Formation exposed in the trench is developed as a vertical succession of four distinct off-platform, deep marine facies. The basal facies is $8.5 \mathrm{~m}$ thick and consists of thinly interbedded gray lime mudstone and mud shale punctuated by laminae to thin grainy beds consisting of skeletal fragments and peloids, some of which are phosphatized. This facies represents deposition of periplatform carbonate mud and sporadic sand as well as hemipelagic terrigenous mud in a lower slope to basin-margin setting (Finney et al. 1997); graptolites are common and very well preserved. The overlying facies consists of $\sim 9 \mathrm{~m}$ of fetid, dark gray to black, slightly siliceous mudstone and shale, with relatively few lime mudstone interbeds. Interlaminations and very thin grainstone beds consist of abundant phosphatized shell fragments and peloids. Phosphate nodules and stringers occur locally. These strata with total organic carbon values of up to 20 to 25 weight percent likely accumulated under anoxic conditions during a sea-level highstand that drowned the platform and stalled carbonate production (Finney et al. 1997). The abundant calcium phosphate (greater than $10,000 \mathrm{ppm}$ ) indicates extensive phosphatogenesis, likely induced by oceanic upwelling (Finney et al. 2007). The preservation of abundant organic matter suggests that an oxygen-minimum zone existed under the upwelling waters. Laminated intervals in these organic-rich beds are composed of great numbers of graptolites, and much of the organic matter consists of graptolite macerals. The distinctive organic-rich facies is succeeded by a $1.5 \mathrm{~m}$-thick facies of laminated brown mudstone that contains significantly fewer phosphatized grains. This facies signals initiation of 


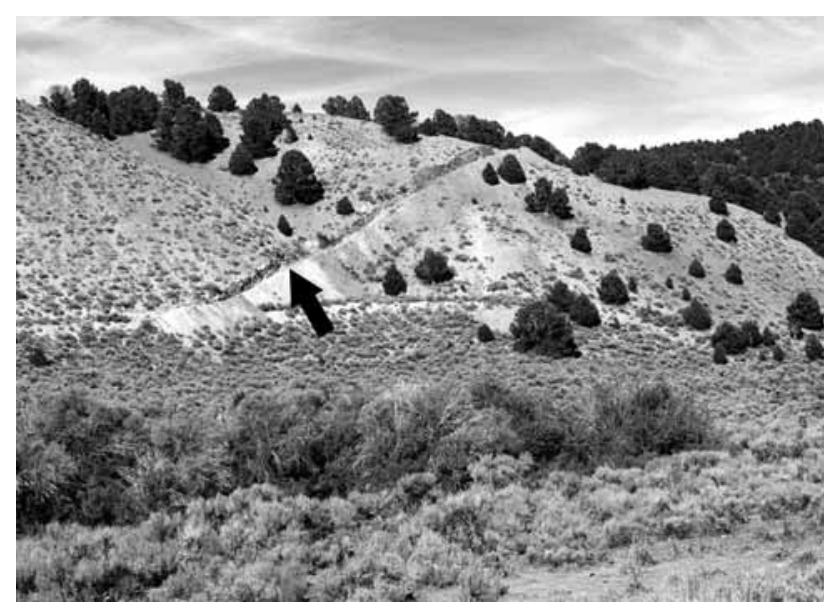

Figure 2. Vinini Creek section exposed by a trench excavated at south facing slope north of Vinini Creek. The trench is shown by a black arrow.

sea-level fall and diminished upwelling accompanied by reduced organic productivity, resulting phosphatogenesis, and size of the oxygen-minimum zone (Finney et al. 1997). Graptolites are abundant but are taxonomically less diverse. The uppermost facies is $9.5 \mathrm{~m}$ of thin- to medium-bedded, tan-gray lime mudstone. These limestones, an accumulation of periplatform ooze, reflect restoration of a relatively robust carbonate factory on a nearby subtidal platform. It developed as sea level dropped to levels more conductive to carbonate production (Finney et al. 1997). Skeletal grains and peloids occur in laminae and very thin beds deposited by sporadic grain flows. Phosphatic material is rare, although some resedimented glauconite is present. Upward through this facies, interlaminated terrigenous mud and scattered rounded quartz silt and very fine to fine quartz sand increase significantly, consistent with a trend of continuing sea-level fall. In spite of the facies change, graptolites are common in many beds, both within the limestone and on bedding surfaces. The disconformable contact with the overlying green shales and interbedded cherts of the middle Llandovery (lower Silurian) Elder Formation, a surface of omission, records not only the maximum sea-level lowstand and subsequent, rapid rise, but also an additional $\sim 5$ million years with no sediment accumulation. An unconformity and absence of graptolites for a similar stratigraphic extent in coeval outer shelf to basinal successions throughout north-central Nevada could reflect long-term contour currents (Finney \& Berry 2003). A similar hiatus appears to be present at this level in Idaho as well, although the putative Hirnantian interval there has not to this point produced diagnostic fossils (Goldman et al. 2007a).

The Monitor Range composite section consists of two, nearby, slightly overlapping sections that expose the full, $215 \mathrm{~m}$ thickness of the Hanson Creek Formation. The Martin Ridge section (N 39¹3' 11.5', W 116 $23^{\prime} 36.2^{\prime \prime}$ ) includes the lower $143 \mathrm{~m}$ of the Hanson Creek Formation (Fig. 4); and the Copenhagen Canyon section (N 39 $12^{\prime} 41.3^{\prime \prime}, \mathrm{W} 116^{\circ} 24^{\prime} 17.2^{\prime \prime}$ ) exposes the upper 105 m (Finney et al. 1997, 1999). The Hanson Creek Formation stratigraphically overlies the shallow-water Eureka Quartzite. The lower $120 \mathrm{~m}$ consists of variations of two main lithologies: bench-forming dark gray lime mudstone and slope-forming gray-brown shaly to platy and thin-bedded clayey lime mudstone and calcareous mudstone (Fig. 4). Graptolites are not common in the lower part of the Martin Ridge Section, but are abundant, diverse, and well preserved in the interval between 95 and $110 \mathrm{~m}$. Above $120 \mathrm{~m}$, where the section is largely lime mudstone, graptolites are absent. Higher in the Hanson Creek Formation the strata consist of, in ascending order: cherty lime mudstone; massive wackstone, packstone and cross-stratified, oolitic dolostone overlain by a karst surface with a thin, quartz sand veneer; fossiliferous packstone; and a uniformly homogeneous facies association of alternating beds of dark gray chert and dark gray lime mudstone. In the upper $105 \mathrm{~m}$ of the Hanson Creek Formation, graptolites are poorly preserved and scarce, having been found in only four small collections. The karst surface and quartz sand veneer is interpreted as the Hirnantian glacio-eustatic sea-level lowstand with the underlying and overlying strata representing sea-level fall and rise, respectively (Finney et al. 1997, 1999; LaPorte et al. 2009). The lower part of the Hanson Creek Formation in the Martin Ridge section does represent, however, somewhat deeper water conditions in a localized basin on the outer part of the western shelf of Laurentia in the Late Ordovician. At this time, the western (modern coordinates) shelf of Laurentia was west-northwest facing and located in the tropics in the Southern Hemisphere.

Extensive and systematic graptolite collections were made from 67 sampling levels of $28.6 \mathrm{~m}$ thick Vinini Creek section (Fig. 3). Earlier sampling campaigns carried out by Finney and his co-workers during the 1990s were supplemented by Mitchell \& Finney in 2005, and by Finney \& Štorch in 2007. Existing material from Martin Ridge section, studied by Dworian (1990), was supplemented by Finney \& Štorch in 2007 by additional collecting in selected levels of upper Di. ornatus and lower Po. pacificus biozones (Fig. 4). All specimens well enough preserved for species identification have contributed to the range (Figs 3,4) and diversity (Fig. 5) charts.

\section{Graptolite biostratigraphy}

Upper Katian and Hirnantian graptolites of central Nevada are abundant and highly diverse and allow for precise biostratigraphic zonation. Four biozones and one subzone are correlatable with graptolite bearing successions of the 


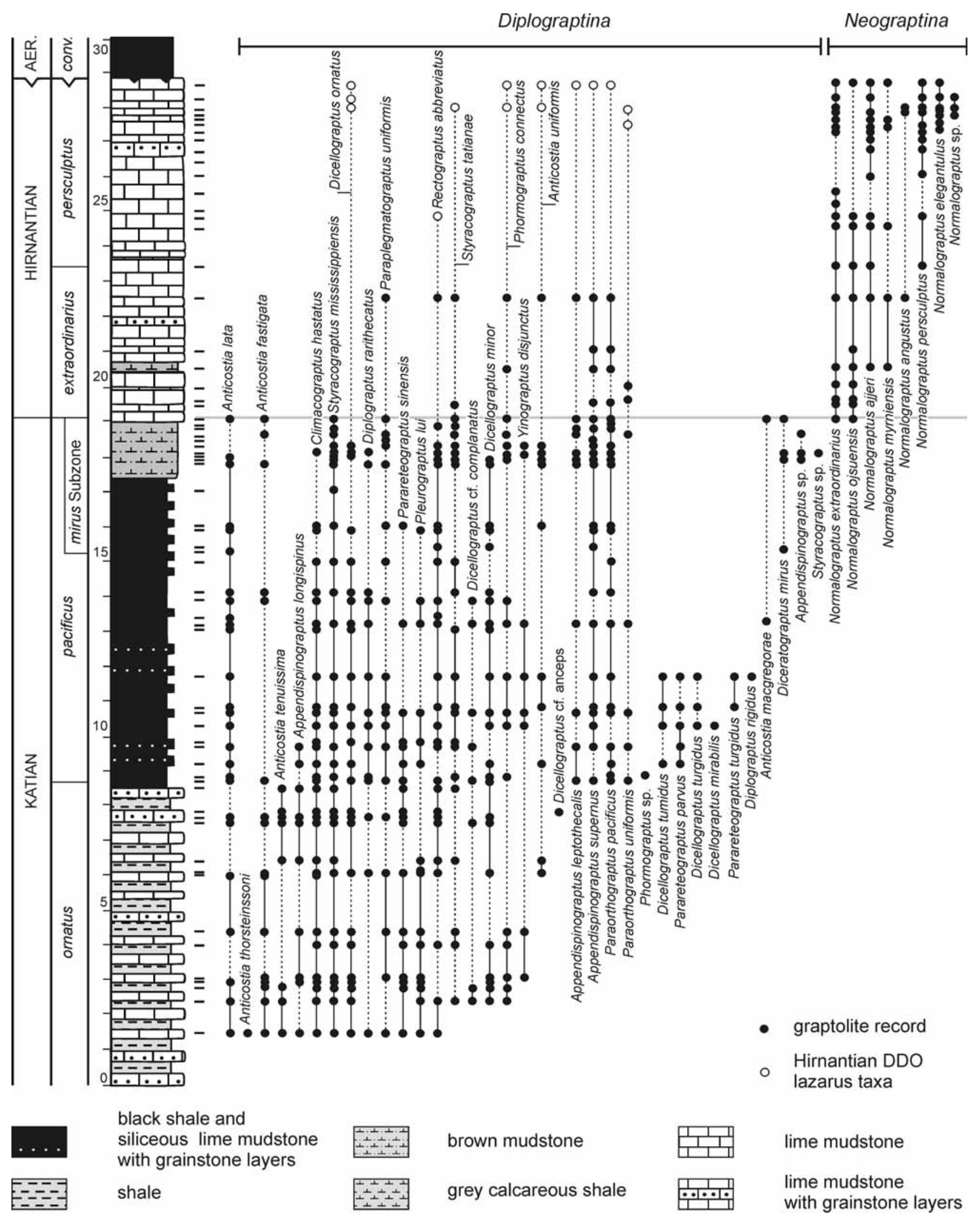

Figure 3. Vinini Creek section: Lithological log (after Finney et al. 1997), graptolite range chart and biostratigraphy. Diplograptine fauna (= Dicellograptid-Diplograptid-Orthograptid, or DDO fauna, of Melchin \& Mitchell 1991) comprises great bulk of the late Katian graptolite species diversity. These data suggest that locally some of its elements survived high into the Hirnantian. 
Chinese Yangtze Platform, Scotland, southern Kazakhstan, north-eastern Siberia and the Yukon Territory and Arctic Islands of Canada.

\section{Dicellograptus ornatus Biozone}

The lower part of the Vinini Creek section has been assigned to the Dicellograptus ornatus Biozone, which is defined here as an interval between the lowest occurrence of Di. ornatus and lowest occurrence of Paraorthograptus pacificus - an index fossil of the overlying biozone. The ornatus Biozone comprises the lowermost $8.7 \mathrm{~m}$ of the Vinini Creek trench section (Fig. 3), although the base and lower part of the biozone are not exposed. The faunal assemblage is rather homogenous throughout this thickness, with Anticostia tenuissima and a few unique occurrences of $A n$ ticostia thorsteinssoni (Melchin) and Dicellograptus cf. anceps confined to this interval. Species diversity is moderate, comprising 8-13 species recovered per sampling level (Fig. 5). The most common taxa are: Anticostia tenuissima, Appendispinograptus longispinus, Climacograptus hastatus, Styracograptus mississippiensis, Dicellograptus ornatus, Parareteograptus sinensis, Pleurograptus lui, and Rectograptus abbreviatus. In the correlative interval of the Martin Ridge section (see Dworian 1990 for further data) the graptolite faunal assemblage is similar (Fig. 4) except for the slightly lower overall diversity and greater relative abundances of Anticostia tenuissima, Appendispinograptus longispinus, Parareteograptus sinensis and Diplograptus rarithecatus. In contrast to previous reports (e.g., Finney et al. 1999, Mitchell et al. 2007) species of Normalograptus are not present in this interval, nor indeed, in any of the Katian strata at Vinini Creek. The Katian graptolite fauna consists entirely of species of the Diplograptina (e.g., species of the dicellograptid-diplograptid-orthograptid, or DDO fauna, sensu Melchin \& Mitchell 1991; see systematic section below for further explanation).

\section{Paraorthograptus pacificus Biozone}

The pacificus Biozone comprises an interval from the lowest occurrence of the zonal index fossil to the lowest occurrence of Normalograptus extraordinarius, which at Vinini Creek also coincides with the first occurrence of Normalograptus ojsuensis. The pacificus Biozone is $10.4 \mathrm{~m}$ thick in the Vinini Creek section and more than $30 \mathrm{~m}$ at Martin Ridge.

The most abundant taxa of the pacificus Biozone are: Anticostia lata, Climacograptus hastatus, Styracograptus mississippiensis, S. tatianae, Dicellograptus minor, Rectograptus abbreviatus, Phormograptus connectus, Appen- dispinograptus supernus, Diplograptus rarithecatus (at Martin Ridge) and Paraorthograptus pacificus. The graptolite assemblage displays a marked increase in species diversity compared to the preceding zone. The recovered assemblage consists of 17-21 species per sampling level in the organic-rich black shale developed in the lower, although not the lowermost, part of the biozone (Fig. 5).

Apart from the zonal index Paraorthograptus pacificus, new appearances include: Appendispinograptus supernus, A. leptothecalis, Paraorthograptus uniformis (in particular at Martin Ridge) and rare Anticostia macgregorae. Several species, particularly Dicellograptus tumidus, Di. turgidus, Di. mirabilis, Parareteograptus parvus, Pr. turgidus and Diplograptus rigidus, are confined to the black-shale interval in the lower part of the biozone.

\section{Diceratograptus mirus Subzone}

In the Vinini Creek trench, species diversity markedly decreases with changes in the lithological succession in the middle part of the pacificus Biozone although some significant taxa nevertheless have their lowest occurrences above this interval of decrease in graptolite diversity. A distinct subzone, tentatively correlative with China (Chen et al. 2000) and northwestern Canada (Chen \& Lenz 1984), can be recognized in the uppermost $3.2 \mathrm{~m}$ of the pacificus Biozone at the Vinini Creek section. The base is taken at the lowest occurrence of Diceratograptus mirus. A unique form of Appendispinograptus (A. sp.) also appears in this unit and is confined to a narrow interval within the subzone.

Common taxa of the mirus Subzone are: Styracograptus mississippiensis, S. tatianae, Appendispinograptus supernus, A. leptothecalis, Anticostia uniformis, Rectograptus abbreviatus, and Paraorthograptus pacificus. Individual bed samples comprised 12-14 species recovered in the middle part of the mirus Subzone whereas the upper part is further impoverished, having just 5-7 species per sampling level.

\section{Normalograptus extraordinarius Biozone}

The extraordinarius Biozone is defined as an interval between the lowest occurrence of Normalograptus extraordinarius (which is here coincident with that of $N$. ojsuensis) and the lowest occurrence of Normalograptus persculptus - the index fossil of the overlying biozone. Species diversity in this interval is moderate. Normalograptus extraordinarius and $N$. ojsuensis are abundant throughout the biozone, whereas $N$. ajjeri, $N$. mirnyensis and rare $N$. angustus made their first occurrences higher in this interval. 


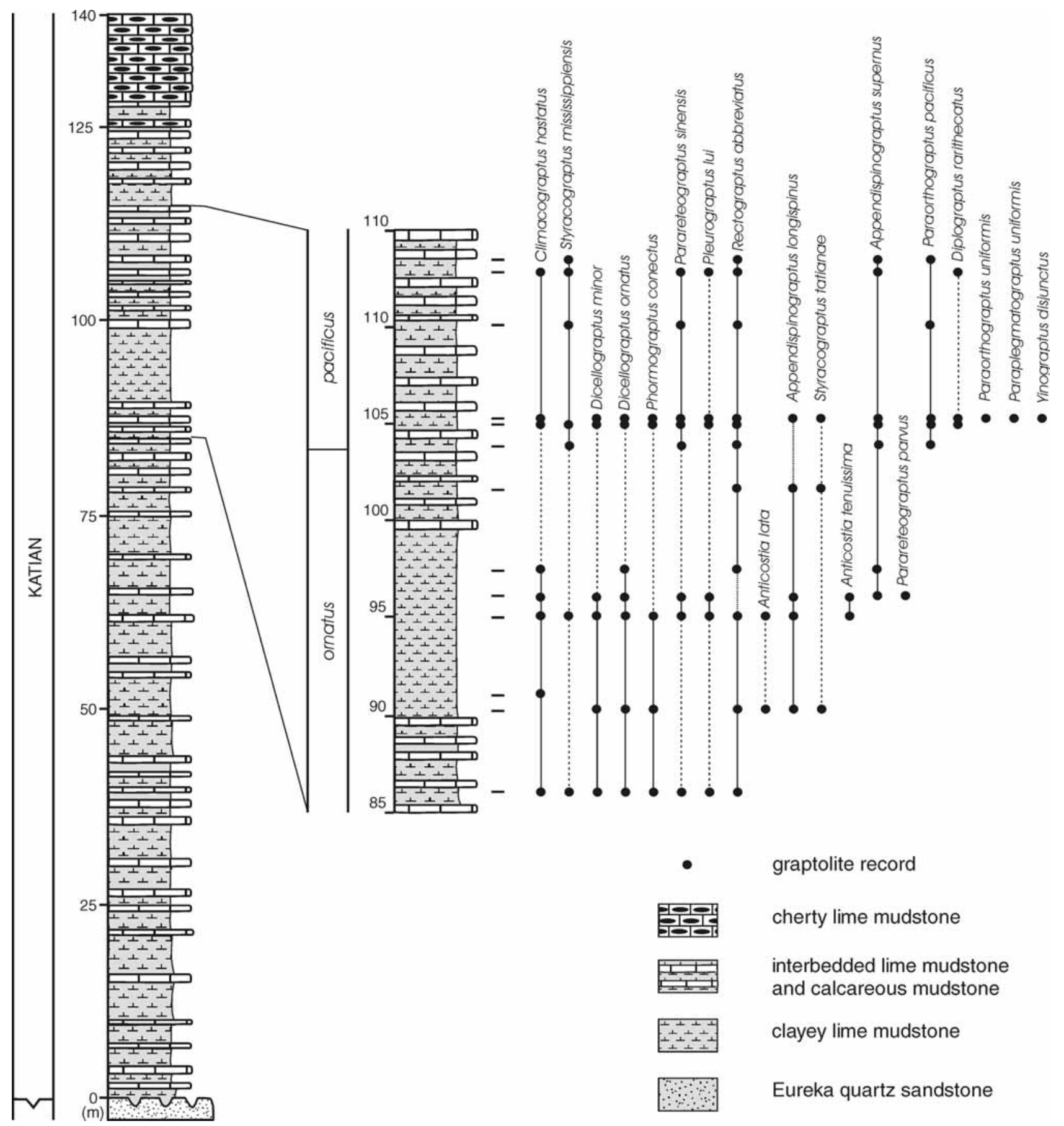

Figure 4. Martin Ridge section: Generalized lithological log (after Dworian 1990 and Finney et al. 1997) and particular inset with graptolite ranges and biostratigraphy across the upper ornatus and lower pacificus biozones.

Fifteen diplograptine species occur in samples from this zone but five have their last appearance in the lowest sample, coincident with the first appearance of the normalograptids at Vinini Creek. The basal bed still contains Anticostia lata, An. fastigata, An. macgregorae, Styracograptus mississippiensis, S. tatianae, S. sp., Paraplegmatograptus uniformis, Phormograptus connectus,
Appendispinograptus leptothecalis, A. supernus, Paraorthograptus pacificus and Po. uniformis. Diplograptines are very rare or absent through most of the biozone, but eight of these species recur in a single sample at the top of the biozone. Despite apparently continuous sedimentation and minor change in lithology, dramatic faunal change took place in this level (Mitchell et al. 2007a). 


\section{Normalograptus persculptus Biozone}

This biozone is recognized by the appearance of the eponymous graptolite and is topped by a prominent disconformity in the Vinini Creek section. It is inferred that the $5.2 \mathrm{~m}$-thick limestone interval represents just the lower part of the actual stratigraphic range of the zonal species, which co-occurs with Normalograptus extraordinarius to the top of the section. This interpretation is consistent with the carbon isotopic record of this section, which appears to truncate the Hirnantian isotopic anomaly (HICE) just below the return to near pre-Hirnantian values recorded in the Monitor Range section (Finney et al. 1999, LaPorte et al. 2009). This steep, post-glacial excursion typically occurs about midway through the persculptus Zone in more complete sections such as Dob's Linn and elsewhere (see Melchin \& Holmden 2006, Fan et al. 2009).

The lower half of the preserved persculptus Biozone is characterized by a low diversity normalograptid assemblage (1-5 species per sampling level) that consists of Normalograptus persculptus, $N$. extraordinarius and $N$. ajjeri. $N$. mirnyensis is rare and $N$. ojsuensis made its highest occurrence shortly above the base. A new significant element among normalograptids - Normalograptus elegantulus - is confined to the uppermost part of the section at Vinini Creek.

The most unexpected discovery made in our study of this interval is the significant rise in graptolite diversity (6-12 species per sampling level) near the top of the Vinini Creek section where several diplograptine species that survived the early phase of mass extinction reappeared as rare Lazarus taxa: Dicellograptus ornatus, ?Phormograptus connectus, Anticostia uniformis, Styracograptus tatianae, Appendispinograptus supernus, ?A. leptothecalis, Paraorthograptus uniformis and ?Po. pacificus. This is the most diverse assemblage of residual diplograptine species ever recorded from the late Hirnantian. Two of these species (An. uniformis, and Po. pacificus) also recur as very rare specimens in the persculptus Zone above the Hirnantia-bearing Kuanyinchiao Beds in the Yangtze Platform region of China along with three other very rare diplograptine species not found among the Lazarus taxa here (Anticostia lata, Paraorthograptus "brevispinus" and Rectograptus abbreviatus; Chen et al. 2000, 2005a), but most have never been recorded from late Hirnantian strata previously. Most of these taxa are represented in this interval at Vinini Creek by one or two specimens, mostly not well preserved, that were overlooked in previous collections of this interval. Whether similar discoveries might be found in other parts of the world, given sufficient collections and the encouragement that previous discoveries in China afforded to us, is uncertain but worth pursuing.

\section{Correlation}

Low-latitude graptolite bearing successions through late Katian and Hirnantian interval are well known and rather complete in Chinese Yangtze Platform (e.g. Mu et al. 1993; Chen et al. 2000, 2005a), Yukon Territory and Arctic islands of Canada (Chen \& Lenz 1984, Melchin 1987, Melchin et al. 1991), north-eastern Siberia (Koren' et al. 1983), southern Kazakhstan (Apollonov et al. 1980, 1988) and British Isles (Toghill 1970; Williams 1982, 1983). These are discussed below, together with mid-latitude successions of peri-Gondwanan Europe which are less suitable for correlation but important to further studies on graptolite faunal dynamics before, through and after the end Ordovician glaciation.

Yangtze Platform of China. - The extraordinarily diverse graptolite assemblage reported by Chen et al. (2000) from the Dicellograptus complexus Biozone of the Wufeng Formation correlates with the less diverse graptolite fauna of the Dicellograptus ornatus Biozone recognized in the lower part of the Vinini Creek trench. Dicellograptus complexus Davies is absent in the measured part of the Vinini Creek section, although was previously reported by Finney \& Berry (1999) and Finney et al. (1999). A single rhabdosome similar to Di. complexus is flattened in a rather atypical oblique position (see Fig. 11V) and actually belongs to Di. ornatus. In China, Dicellograptus ornatus Elles \& Wood makes its lowest occurrence above the base of the complexus Biozone. Our detailed study suggests that there are many differences in the relative levels of lowest occurrences of the graptolite species between China and Nevada. Graphic correlation is pending but requires further systematic revision of Chinese late Katian graptolites, similar to that done by Chen et al. (2005a), which focused on the Hirnantian fauna. The Paraorthograptus pacificus Biozone of the Wufeng Formation (Chen et al. 2000) matches well the same zone recognized in the Vinini Formation, although its tripartite subzonal division is not possible in the Nevada succession. The lowest, so far unnamed subzone of the $p a-$ cificus Biozone of Chen et al. (2000) correlates with lower part of the pacificus Biozone at Vinini Creek, bearing Dicellograptus tumidus Chen, Di. turgidus $\mathrm{Mu}$ and highest occurrences of Pleurograptus lui Mu. Tangyagraptus typicus $\mathrm{Mu}$, which is highly significant index graptolite of the middle subzone in Wufeng Formation, has never been reported from outside China. The index species of the upper subzone, Diceratograptus mirus $\mathrm{Mu}$, however, was found in Yukon Territory of Canada by Chen \& Lenz (1984) and it also occurs in the upper part of the pacificus Biozone at Vinini Creek (see also Mitchell et al. 2007a) as well as in the Trail Creek succession in Idaho (Goldman et al. 2007). In Chinese sections, the Diceratograptus mirus Subzone occupies only a very thin stratigraphic interval that coincides 
with lowest occurrences of normalograptid graptolites whereas at Vinini Creek Dc. mirus Subzone occupies more than the upper third of the pacificus Zone. Therefore, our correlation of the bases of this subzone between Nevada and China must be regarded as tentative.

According to Chen et al. (2005a) Normalograptus extraordinarius-N. ojsuensis Biozone of the Yangtze Platform comprises a rich assemblage of diverse normalograptids accompanied by several diplograptine survivors of early Hirnantian mass extinction. In contrast with the Vinini Creek section, $N$. ojsuensis does not extend into the overlying Normalograptus persculptus Biozone in China. Diplograptine elements essentially disappear in the lower part of the persculptus Biozone in Yangtze Platform sections as does $N$. extraordinarius. The prominent normalograptid proliferation and radiation that gave rise to the origin of Neodiplograptus and Sudburigraptus in the upper part of the persculptus Biozone (see Chen et al. 2005a) falls, for the most part, in the late Hirnantian, which is not preserved at Vinini. None of the other sections in Nevada have been found to have graptolite bearing beds corresponding with the upper Hirnantian.

Northern Canada. - The upper Katian graptolite succession of Yukon Territory has been divided into two biozones by Lenz \& McCracken (1988). A lower Dicellograptus ornatus Biozone is well correlatable with the ornatus Biozone recognized in the Vinini Creek and Monitor Range sections of Nevada. A less diverse graptolite assemblage was reported from overlying Paraorthograptus pacificus Biozone in the upper part of which Diceratograptus mirus has been encountered by Chen \& Lenz (1984). Normalograptus extraordinarius Biozone has been reported by LaPorte et al. (2009) from the Blackstone River section in northern Yukon, and a detailed biostratigraphic analysis is in progress by Loxton (pers. comm. 2010). Similarly, the graptolite fauna of Normalograptus persculptus Biozone, reported by Lenz \& McCracken (1988) and cited also by LaPorte et al. (2009) is also currently under study.

The Cape Phillips Formation of the Canadian Arctic Islands yielded low- to moderate-diversity upper Katian graptolite assemblages assigned to lower Anticostia fastigata Biozone and upper Paraorthograptus pacificus Biozone by Melchin (1987). The fastigata Biozone is tentatively correlatable with Di. ornatus Biozone of Yukon territory and Di. complexus Biozone of Scotland (Melchin 1987), although no dicellograptids have been found in Arctic Islands sections to date. Melchin et al. (1991) recovered normalograptid assemblages, tentatively correlatable with $N$. extraordinarius- $N$. ojsuensis Biozone, a few centimetres above highest occurrence of Po. pacificus and its diplograptine associates in Truro Island. They also recognized the $N$. persculptus Biozone below the earliest Silurian fauna, but correlations based on carbon isotope data suggest that most the Hirnantian graptolite-bearing strata in Nevada (with the exception of the basal extraordinarius Biozone) correlate with unfossiliferous intervals in the sections studied in Arctic Canada (Melchin \& Holmden 2006).

North-eastern Siberia. - In the Mirny Creek region (Omulev Mountains) of NE Siberia Koren' et al. (1983) recognized the Appendispinograptus longispinus and Paraorthograptus pacificus subzones within upper Katian $A$. supernus Biozone. The biostratigraphy of the uppermost Katian to lowest Rhuddanian part of the succession was updated and slightly revised by Koren' \& Sobolevskaya (2008). Only eight sample levels were reported in the supernus Biozone at Mirny Creek (only two in the lower subzone), which does not allow for high resolution correlation. Graptolite assemblages of the lowest two sampling levels match the Dicellograptus ornatus Zone assemblage of central Nevada although Di. ornatus Elles \& Wood is limited to the lowest sample levels assigned to their pacificus Subzone. The diplograptine fauna was abruptly replaced by normalograptids at the base of lower Hirnantian Normalograptus extraordinarius Biozone in the Mirny Creek region. Only a single occurrence of a diplograptine taxon, Paraorthograptus cf. pacificus, was found in the lowest Hirnantian strata (Koren' \& Sobolevskaya 2008). On the other hand, Normalograptus ojsuensis is restricted to strata of the uppermost pacificus Subzone. The graptolite fauna reaches its lowest diversity in the upper (but not uppermost) part of Normalograptus persculptus Biozone. The OrdovicianSilurian boundary interval at Mirny Creek is marked by a shift from dolomitic marlstones and siltstones to mainly black shales. This transition was interpreted by Koren' et al. (1983) to represent a rapid transgression and the lowest age-diagnostic graptolite samples in the black shales are lowest Rhuddanian, similarly as in many sections in the peri-Gondwanan Europe (Bohemia, Thuringia, Spain, in part Italy and Austria). This contrasts, however, with many other regions (e.g. Northern Canada, Scotland, South China) where the transgressive graptolitic shales are upper Hirnantian. This may also indicate that the late Hirnantian (i.e. the upper part of the persculptus Biozone at Mirny Creek and in many peri-Gondwanan sections may be missing (as at Vinini Creek) or highly condensed.

Southern Kazakhstan. - The upper Katian and Hirnantian succession described by Apollonov et al. (1980) from Chu Ili Mountains of southern Kazakhstan has been divided in Appendispinograptus supernus and Normalograptus persculptus biozones. The graptolite assemblage of the $s u$ pernus Biozone includes both Dicellograptus ornatus and Paraorthograptus pacificus (Ruedemann) along with $D i$ cellograptus minor Toghill, Styracograptus tatianae (Keller), Amplexograptus stukalinae Mikhaylova (= Anticostia 
lata of this paper) and Appendispinograptus hvalross (Ross \& Berry) (= Appendispinograptus sp. of this paper). This level of the Kazakhstanian sections is correlatable with the pacificus Biozone of central Nevada. N. ojsuensis occurs mainly in strata assigned to the upper part of the $s u$ pernus Biozone, although it also occurs in a sample assigned to the lowest Hirnantian. Apollonov et al. (1988) provided clear evidence for the occurrence of the extraordinarius Biozone in southern Kazakhstan, enabling correlation with the extraordinarius Biozone of Nevada. The persculptus Biozone is recognized by the index graptolite, but is not accompanied by either $N$. ojsuensis or N. extraordinarius in continuous sections of southern Kazakhstan. No diplograptine survivors have been reported from Hirnantian strata of that area. Sampling across the Ordovician-Silurian boundary in South Kazakhstan was too sparse to draw any definitive conclusions concerning the details of faunal or stratigraphic continuity through that interval.

British Isles. - The Dicellograptus anceps Biozone introduced by Lapworth (1878, p. 316) in the Moffat area of southern Scotland has been subdivided in lower Di. complexus and upper Po. pacificus subzones by Williams (1982). The fauna of the Di. complexus Subzone includes Dicellograptus anceps (Nicholson), Di. minor Toghill, Pleurograptus lui Mu, Anticostia fastigata (Davies), An. lata (Elles \& Wood), Rectograptus abbreviatus (Elles \& Wood), Appendispinograptus supernus (Elles \& Wood), Parareteograptus sinensis $\mathrm{Mu}$, Styracograptus miserabilis (Elles \& Wood) and N. normalis (Lapworth). Although Williams (1982) did not illustrate any specimens of N. normalis, one of us (MJM) has resampled the anceps bands at Dob's Linn and found that the specimens assigned to N. normalis by Williams (1982) may be climacograptids, possibly Styracograptus mississippiensis (Ruedemann). Many of these taxa suggest a correlation, at least in part, with Dicellograptus ornatus Biozone of the Vinini Creek section, although in Scotland Di. ornatus has its lowest occurrence as high as in the middle of the overlying Po. pacificus Subzone. The Po. pacificus Subzone exhibits the maximum graptolite diversity within upper Katian succession of the British Isles. Graptolites of probable anceps Zone have been reported also from Wales (Davies et al. 1997) but without potential for more detailed biostratigraphic subdivision or precise correlation.

The N. extraordinarius Biozone was recognized only in Scotland, in two isolated graptolite bearing bands within mostly barren Upper Hartfell Shale (Williams 1988). $N$. extraordinarius is accompanied by several diplograptine taxa, including Di. anceps and undoubted Dicellograptus turgidus $\mathrm{Mu}$ (= Di. ornatus figured by Williams 1982, pl. 1, fig. 8) in the lower extraordinarius-bearing band (= anceps Band E of Williams 1982, 1988), which presumably corresponds to lower or even lowermost part of the extraordinarius Biozone (Melchin et al. 2003). The upper extraordinarius band was reported by Williams (1983) to be dominated by the eponymous species accompanied by few other normalograptid forms, but Melchin et al. (2003) reported the occurrence of $N$. persculptus at that level along with $N$. extraordinarius and suggested that this level should mark the base of the persculptus Biozone. The upper part of the persculptus Biozone is well represented in Scotland (Williams 1983) in the basal $1.6 \mathrm{~m}$ of the Birkhill Shale, below the GSSP for the base of the Silurian System. The upper part of the persculptus Biozone is known also from Wales and England (Zalasiewicz et al. 2009) below the base of Silurian Akidograptus ascensus-Pararakidograptus acuminatus Biozone.

Peri-Gondwanan Europe. - Katian graptolite faunas of the middle to high-latitude realm are rare, scattered and rather different from the tropical faunas of Nevada or the Chinese Yangtze Platform. Limited resolution can be achieved by their correlation. Rare dicellograptids (Dicellograptus laticeps Štorch and Di. cf. morrisi Hopkinson) accompanied by relatively common specimens of Normalograptus angustus (Perner) and rare Phormograptus? chuchlensis (Přibyl) are known from Králův Dvůr Formation in the Barrandian area of central Bohemia (Štorch 1989) and roughly correlate with Dicellograptus anceps Biozone of the British Isles. Skevington \& Paris (1975) reported several diplograptid species, tentatively assigned to Rectograptus $a b$ breviatus (Elles \& Wood) and Anticostia fastigata (Davies), from Saint-Germain-sur-Ille Formation of the Armorican Massif. Lower Hirnantian graptolites are confined to single layers with Normalograptus ojsuensis and possible N. extraordinarius in the Barrandian area of Bohemia (Štorch 1989) and in south-western Sardinia (Štorch \& Leone 2003). Late Hirnantian Normalograptus persculptus is more common in the Gondwanan part of Europe. Monospecific assemblages have been reported from largely late-glacial to post-glacial transgressive successions of Carnic Alps (Jaeger et al. 1975), Sachsen (Jaeger 1977) and central Bohemia (Štorch \& Loydell 1996).

\section{Graptolite faunal dynamics}

Pelagic graptolites experienced a significant increase in extinction rates during the late Katian and into the early Hirnantian at the same time as many other invertebrates (summarized in Sheehan 2001). Graptolite extinction rates reached a peak during the early Hirnantian Normalograptus extraordinarius Biozone (Berry et al. 1990, Koren' 1991, Melchin \& Mitchell 1991, Finney et al. 1999, Chen et al. 2005b), coincident with the first wave of the Hirnantian mass extinction, which was itself associated with a 
peak advance in the latest Ordovician Gondwanan glaciation and related climate and oceanographic changes (Brenchley et al. 1994, 2003; Sheehan 2001; Chen et al. 2005b; Finney et al. 2007; LaPorte et al. 2009).

The Hirnantian mass extinction exhibited a strong taxonomic selectivity among paleotropical graptolites. The dominant Ordovician clades (named the DDO fauna by Melchin \& Mitchell 1991, for the families Dicranograptidae, Diplograptidae, and Orthograptidae that comprised the great bulk of the late Katian graptolite species diversity and referred to here as diplograptine clades) were decimated during the $N$. extraordinarius Biozone interval, whereas species of genus Normalograptus both survived differentially and underwent rapid diversification (Melchin \& Mitchell 1991, Finney et al. 1999, Chen et al. $2005 \mathrm{~b}$ ). The precise timing and severity of graptolite extinction, however, varied across the paleotropical shelves. The somewhat protected Yangtze Platform region appears to have had both the highest Katian diversity of graptolites and the longest persistence of diplograptine species as common members of the normalograptid-dominated early Hirnantian faunas, whereas currently available evidence from other regions within the paleotropics suggests that they had somewhat lower starting diversities and more rapid decline of diplograptine diversity during the Hirnantian. Similar differences distinguish the history of the Hirnantian Mass Extinction at outer shelf versus more on-shore settings, even within the highly diverse Yangtze Platform region faunas (Chen et al. 2000, 2004, 2005b; Mitchell et al. 2007a). Thus, the outer shelf Martin Ridge section faunas examined here are substantially lower in diversity than those recovered from the slope-basin margin deposits of the Vinini Creek section and the former reveal a much more drastic loss of species during the Hirnantian than do the latter (Finney et al. 1997, 1999, 2007, and herein). These on-shore to off-shore patterns are due in part to facies and taphonomic effects, but also appear to reflect original differences in the standing graptolite populations, which were more restricted in the more shallow-water sections (Chen et al. 2005b, Finney et al. 2007).

Major features of the late Katian-Hirnantian graptolite faunal dynamics have been largely inferred from data obtained from the more thoroughly studied and more fossiliferous Vinini Creek section (Fig. 5). For purposes of discussion of the faunal dynamics, the succession as a whole is subdivided into five intervals characterized by specific events in graptolite dynamics.

Dicellograptus ornatus Biozone interval. - The lower part of the Vinini Creek Section (Figs 3, 5, 0-8.5 m), composed of interbedded lime mudstones and partly bleached brown to black shales, harbours abundant graptolites of late Katian diplograptine fauna (DDO fauna in the sense of Melchin \& Mitchell 1991). (Note that the Finney et al. (1999)

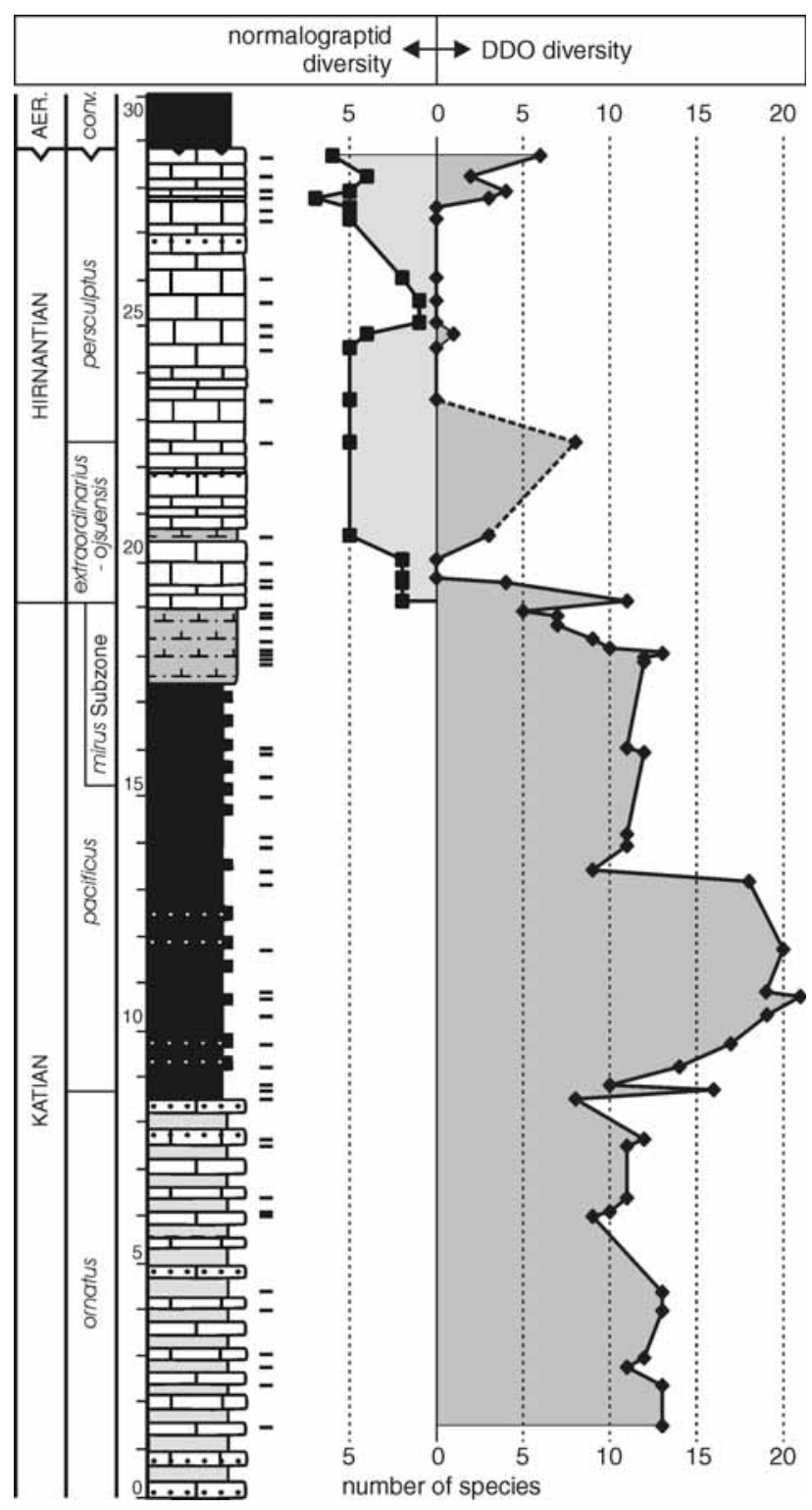

Figure 5. Graptolite faunal dynamics (diversity curves) plotted against simplified Vinini Creek section log. See Fig. 3 for lithology. Graptolite diversity per sampling level is composed of positive records (after Fig. 3) and presumable occurrences determined by interpolation between positive records in neighbouring levels above and below. Ten of 66 sampling levels have been omitted due to small size of the sample which does not approach real species diversity. Graptolite records from sampling levels situated in couples only $5 \mathrm{~cm}$ apart $(2.95$ and $3.00 \mathrm{~m}, 13.15$ and $13.20 \mathrm{~m}$, 27.45 and $27.50 \mathrm{~m}$ ) have been merged and referred to $3.00,13.15$ and $27.50 \mathrm{~m}$, respectively.

and Mitchell et al. (2007a) documented sporadic occurrences of normalograptids within the ornatus and pacificus biozones at Vinini Creek, but these specimens are here considered to belong to species of Styracograptus n. gen.). Graptolite assemblages recorded in sampling levels of this interval are composed of 9-13 species, without high-dominance taxa. Only two species are very rare and 
confined to one sampling level (Anticostia thornsteinssoni and Dicellograptus cf. anceps).

Paraorthograptus pacificus Biozone interval (excluding uppermost $1.5 \mathrm{~m}$ ). - Still higher graptolite diversity and abundance occur in the organic-rich black shale interval from $8.5 \mathrm{~m}$ to $17.5 \mathrm{~m}$. Both diversity and abundance reached their maxima in the lower part of the black-shale interval that corresponds with the lower part of the pacificus Biozone. Paraorthograptus pacificus and several species shared with $\mathrm{Wu}$ feng Formation of Yangtze platform of China ( $\mathrm{Mu}$ et al. 1993, Chen et al. 2005a) joined the assemblage in the lowest part of the black shale interval. Maximum diversity of 21 taxa was attained at the level of $10.7 \mathrm{~m}$ of the section (Figs 3, 5). High graptolite abundance and diversity correlate with low $\delta^{13} \mathrm{C}$ values and high TOC values. High-organic productivity and a well-developed denitrification Zone associated with high sea-level can be inferred from such coincidence in according to the Finney and Berry model of graptolite ecology (Finney \& Berry 1997).

Higher in the black shale interval, graptolite diversity returned to values of the underlying ornatus Biozone as several, apparently short-lived taxa disappeared (such as Dicellograptus tumidus, Di. turgidus, Parareteograptus turgidus and Pa. parvus).

Middle-upper Diceratograptus mirus Subzone interval. In the upper pacificus Zone, in organic rich brown mudstones of the middle part of Diceratograptus mirus Subzone, graptolite diversity became slightly elevated once more (maximum 13 species at $18.0 \mathrm{~m}$ ) before it rapidly decreased in the upper part of the subzone. The dramatic downfall of the diplograptine fauna illustrated by Fig. 5 coincides with rising $\delta^{13} \mathrm{C}$ values reported by LaPorte et al. (2009) in this level. The major diplograptine decline took place in the upper part of Diceratograptus mirus Subzone and further coincides with substantial drop in TOC values and onset of largely carbonate sedimentation. Finney \& Berry (1999) and Finney et al. (2007) explained this turn-over by loss of upwelling conditions and disruption of graptolite habitats associated with oxygen minimum Zone due to glacioeustatic sea-level drawdown and oceanographic changes.

Normalograptus extraordinarius Biozone interval. - Two normalograptid taxa - Normalograptus extraordinarius and $N$. ojsuensis have their first occurrence in the sample level of $19.1 \mathrm{~m}$, which represents the base of the Hirnantian Stage. This collection also includes eleven rare diplograptine taxa, but Mitchell et al. (2007a) and our data show that the samples of this biozone and the overlying persculptus Biozone are strongly numerically dominated by specimens of normalograptids.

Normalograptids are well known to occur in relatively organic-poor earlier Katian strata of mid latitudes (e.g.
Normalograptus angustus in Králův Dvůr Formation of Bohemia). At the beginning of Hirnantian ice age, normalograptids, presumably already well adapted to less nutrient rich and cooler settings, appear to have invaded the changing pelagic habitats of the tropical belt, replacing its declining diplograptine fauna (Mitchell et al. 2008). In the Normalograptus extraordinarius Biozone, at the time of high $\delta^{13} \mathrm{C}$ values, low diversity normalograptid assemblages proliferated, and were only intermittently accompanied by diplograptine taxa. At the level of $22.5 \mathrm{~m}$, just below the first appearance of Normalograptus persculptus (Elles \& Wood), moderately diversified normalograptids (5 species) were associated with rare but diverse diplograptine species, such as Anticostia uniformis, Rectograptus abbreviatus, Paraorthograptus pacificus, Paraplegmatograptus uniformis, Phormograptus connectus, Appendispinograptus supernus and Styracograptus tatianae.

Normalograptus persculptus Biozone interval. - Graptolite diversity and abundance dropped to their minima in the lower part of the persculptus Biozone in the Vinini Creek section. However, $N$. persculptus and a few other normalograptid taxa, including $N$. extraordinarius, proliferated once more in the uppermost part of the section. The graptolite and isotopic record and prominent stratigraphic unconformity at the top of Hirnantian lime mudstone succession suggest that the upper part of the persculptus Biozone (early part of the post-glacial transgressive interval), known from Dob's Linn, Arctic Canada (Melchin \& Holmden 2006), northeastern Siberia (Koren' et al. 1983) or Yangtze Platform of China (Fan et al. 2009), is missing in the Vinini Creek section due to non-deposition. The end of the Hirnantian glaciation, however, was already signalled (LaPorte et al. 2009) by falling $\delta^{13} \mathrm{C}$ values in the uppermost two Hirnantian samples of the Vinini Creek section.

The most striking feature of the persculptus Biozone of this section is the recurrence and rise in diversity of diplograptine Lazarus taxa (Di. ornatus, An. uniformis, Po. pacificus, Po. uniformis, Ph. connectus, A. supernus, A. ?leptothecalis and S. tatianae). The high level of sampling density and relative completeness of the fossil record in the Vinini Creek section clearly illustrates the complexity of the pattern of graptolite faunal turn-over and extinction. It is clear that, apart from collection failure (see also Mitchell et al. 2007a), local disappearance of species does not necessarily indicate their extinction. Diplograptine faunal elements repeatedly reappeared within the Hirnantian succession at Vinini Creek. This suggests the existence of refugia in which habitats preferred by graptolites persisted continuously during Hirnantian glacial period. Chen et al. (2005a, b) suggested that semi-restricted Yangtze Platform of China, which yields the most diverse Hirnantian graptolites, including some moderately abundant 


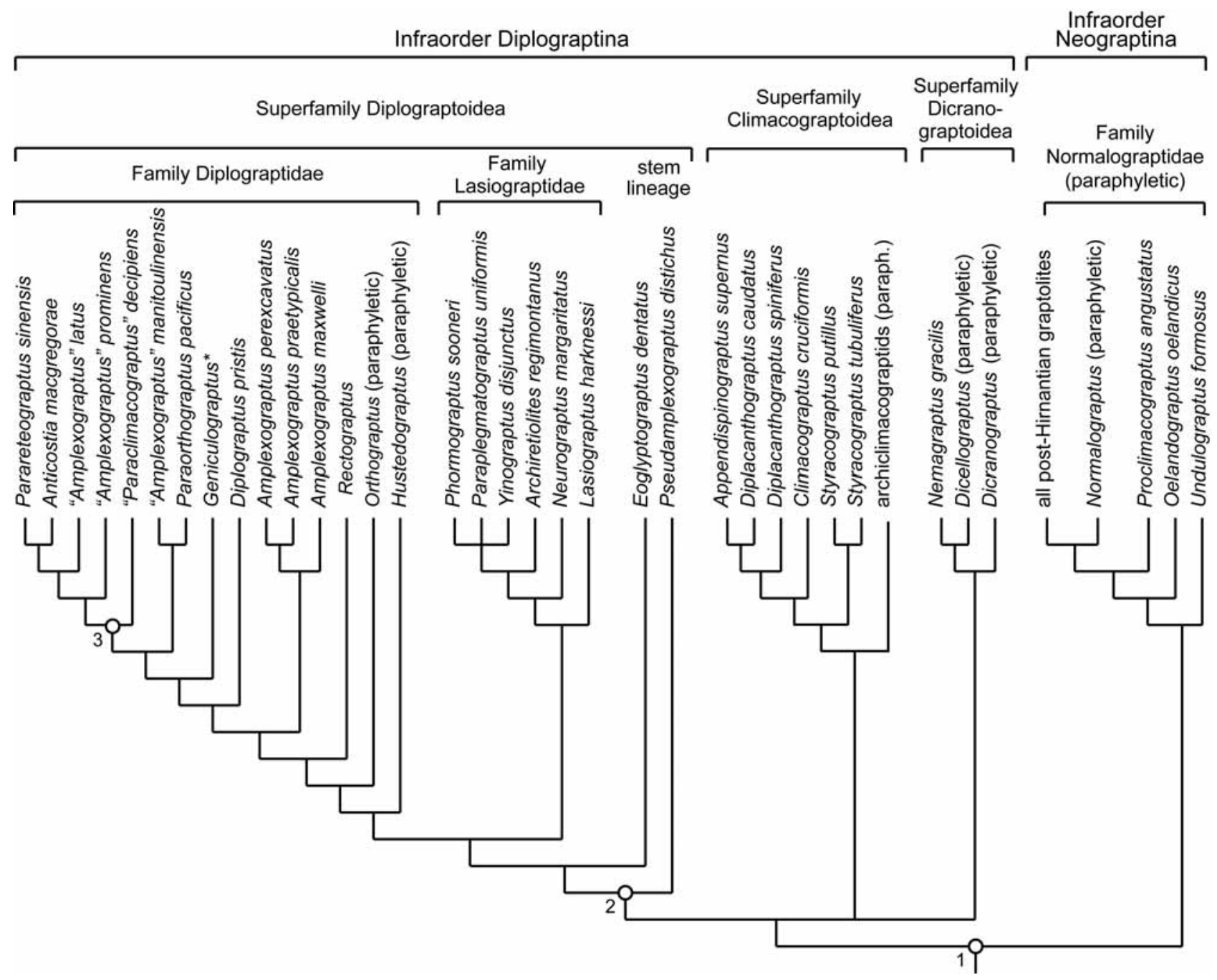

Figure 6. Phylogenetic tree (simplified from Mitchell et al. 2007b by omission of taxa not relevant to the matters at hand) of the Suborder Axonophora (emend. Maletz et al. 2009). Numbered node 1 marks the division between the total clades - infraorders Diplograptina (Lapworth, emend.) and Neograptina (new). Node 2 corresponds to the common ancestor of the Superfamily Diplograptoidea. Node 3 is the common ancestor of paraphyletic taxon Anticostia, in the newly expanded sense (excluding Pararetiograptus), and Parareteograptus. Taxa transferred to Anticostia are shown here with their original generic names in quotes to emphasize the multiply polyphyletic nature of Amplexograptus as it has been used recently. Similarly "Amplexograptus" manitoulinensis is here transferred to Paraorthograptus, restricting Amplexograptus to its type, A. perexcavatus (Lapworth), and its close sister species, all of which are Sandbian to early Katian in age. NB: Paraphyletic stem taxon Normalograptidae includes Normalograptus and the basal taxa of Neograptina but is not intended to include all post-Hirnantian members of this clade (e.g. not monograptids or retiolitids).

diplograptine species, might have provided such a refuge. Even in China, however, records from individual sections show discontinuous distribution of diplograptine taxa through the Hirnantian (Chen et al. 2000).

If the combined carbon and nitrogen isotope, TOC, and sedimentary records provided by Finney et al. (1999), LaPorte et al. (2009) and others are correctly interpreted, the diplograptine Lazarus taxa apparently survived the maximum Hirnantian glaciation and sea-level lowstand. It would also imply that the last phase of diplograptine extinction took place during postglacial transgression, in the course of a major evolutionary burst among normalo- graptids and their descendants, and the reasons for ultimate diplograptine extinction may be biological rather than environmental.

\section{Systematic palaeontology}

Preservation and repository of the graptolite material. Lime mudstones, especially the thinly laminated beds, yield flattened specimens that commonly preserve considerable thecal details, long spines, unbroken virgellae, nemata and complex frameworks of lasiograptids. Organic rich black 
shales are an equally good host but graptolite rhabdosomes exhibit low contrast in fresh rock. Distinct effects of tectonic strain change proportions and measured parameters of some rhabdosomes preserved in black shale by as much as $10 \%$. Slight deformation has been observed also in several lime mudstone beds in the extraordinarius and persculptus biozones. Brownish mudstones deposited in the upper $p a$ cificus Biozone are crowded by flattened, largely climacograptid rhabdosomes, also slightly deformed. Specimens in sparry limestone beds of the ornatus Biozone are well preserved in low relief without any signs of tectonic strain. Detailed morphological measurements were made on almost 600 specimens. Major parameters of mostly figured specimens are provided in the respective tables for each taxon. Illustrated and measured specimens from Vinini Creek and Martin Ridge sections are housed in U.S. National Museum of Natural History and bear USNM designation. Specimens with numbers prefixed GSC are housed with the Geological Survey of Canada.

Taxonomic conventions. - In the following systematic section we attempt to incorporate the results of recent phylogenetic analysis of graptolites and to integrate elements of the suprageneric taxonomy of Mitchell et al. (2007b) and Maletz et al. (2009). The phylogeny of graptolites is strongly asymmetrical with many successive pectinate branches. Creating named holophyletic clades that reflect patterns of sister-group and nesting relationships in such circumstances leads to many nested taxa that differ very little in content. Accordingly we choose to establish named taxa that correspond to only the most well-known and well-supported holophyletic clades (primarily at major branch points in graptolite history) and leave unnamed, paraphyletic stem groups between successive named clades (Fig. 6). We also seek to avoid unnecessary neologisms where possible but at the same time recognize that applying an historical name to a considerably expanded clade, as Mitchell (1987) did in extending the name Monograptina to include the Middle Ordovician biserial graptolites that formed the root of the clade that includes the Monograptidae (sensu stricto), is confusing and contrary to name stability. Unfortunately, the naming of nested monophyletic clades that respect the need to the coordinate the rank of sister clades and all included clades requires greatly expanding the number of ranks in the Linnaean hierarchy, which diminishes the mnemonic value of the ranks. Thus, we do not follow precisely the taxonomy suggested recently by Maletz et al. (2009) but prefer a slightly simpler system with fewer named clades. Several of us (CEM and MJM) are working toward a full revision of the phylogenetic systematics of the graptolites and in order to be consistent with the emerging taxonomy, we propose to establish here the new higher taxon Neograptina at the rank of infraorder (Fig. 6). This somewhat elevated rank is needed to facili- tate naming of the diverse array of Neograptina that evolved within the Silurian. We do not however, undertake a broader consideration of the subclade structure and taxonomy within the Neograptina as this is beyond the scope of the present study.

In addition to forming a new higher taxon, we take this opportunity to split several polyphyletic genera into more meaningful clades. Given the pectinate character of the graptolite phylogenetic trees, we are unable to entirely avoid paraphyletic genera, however. The following is a list of the higher level taxa and genera dealt with in this paper and is not a full list of the generic contents of the higher taxa. The phylogenetic framework of these taxa is summarized in Fig. 6 based on analyses reported by Mitchell et al. (2007b):

Suborder Axonophora
Infraorder Diplograptina
Superfamily Dicranograptoidea
Genus Dicellograptus
Genus Diceratograptus
Genus Pleurograptus
Superfamily Diplograptoidea
Family Diplograptidae
Genus Diplograptus
Genus Rectograptus
Genus Paraorthograptus
Genus Anticostia
Genus Parareteograptus
Family Lasiograptidae
Genus Phormograptus
Genus Paraplegmatograptus
Genus Yinograptus
Superfamily Climacograptoidea
Genus Climacograptus
Genus Styracograptus (new)
Genus Appendispinograptus
Infraorder Neograptina (new)
Family Normalograptidae (paraphyletic stem taxon)
Genus Normalograptus

Suborder Axonophora Frech, 1897; emend. Maletz et al., 2009

The Axonophora appears to comprise two major clades (Fig. 6), one of which, the Diplograptina (sensu Mitchell et al. 2007b; = "diplograptids" in Maletz et al. 2009), includes most of the biserial taxa referred to the Diplograptina sensu Bulman (1970) but differs in that it includes dicranograptids and relatives and excludes normalograptids and their close relatives. This clade consists of three named subclades: the superfamilies Dicranograptoidea (within 
which we include Pleurograptus and several other multi-stiped taxa), Diplograptoidea, and the Climacograptoidea. They are regarded here as three equal rank taxa incertae sedis because their mutual sister-group relations are currently unresolved (see Mitchell et al. 2007b). These three superfamilies are the so-called DDO clades of Melchin \& Mitchell (1991; see also Chen et al. 2005b). In addition, we introduce here a new name, the Neograptina, for the sister taxon to the Diplograptina. Thus, the Neograptina replaces the use of the name Monograptina advocated by Mitchell (1987) to encompass the entire clade sister to the Diplograptina. The Neograptina clade includes a relatively low diversity stem lineage that originated in the earliest Darriwilian along side the Diplograptina, (the earliest known member is Undulograptus formosus). This stem lineage includes species of the genera Proclimacograptus and Normalograptus in the Middle and Late Ordovician and that gave rise to the early Silurian radiation of biserial and uniserial (monograptid) graptolites. We tentatively refer all of these stem-lineage taxa to the paraphyletic family Normalograptidae Štorch \& Serpagli, 1993.

Infraorder Diplograptina (Lapworth, 1880, emend.)

Diagnosis. - The Diplograptina is the total clade comprising all species sharing a more recent common ancestor with Diplograptus pristis than with Monograptus priodon (i.e., species on the branches arising from the left side of node 1 in Fig. 6 and all their descendents).

Description. - The primitive species of this clade exhibit rhabdosomes with a relatively symmetrical proximal end in which both th $1^{1}$ and th $1^{2}$ exhibit subapertural spines, the proximal structure is of the Pattern $\mathrm{C}$ type and thecae have somewhat reduced prothecal overlap compared to the more primitive undulograptid double-sigmoid thecal form. More derived species exhibit a diverse array of colony forms and thecal structures, including species with multiple stipes such as Pleurograptus and complex retiolite-type forms within the Lasiograptidae (discussed in more detail below).

Included taxa. - Superfamilies Dicranograptoidea, Diplograptoidea and Climacograptoidea.

Superfamily Dicranograptoidea Lapworth, 1873, emend. Mitchell et al., 2007b

Discussion. - Several recent phylogenetic studies suggest that Dicranograptus, Dicellograptus, Nemagraptus and their relatives form a clade (Fortey \& Cooper 1986, Mitchell 1987) and that this clade was derived from within the Diplograptina (Mitchell et al. 2007b). Within this group evi-

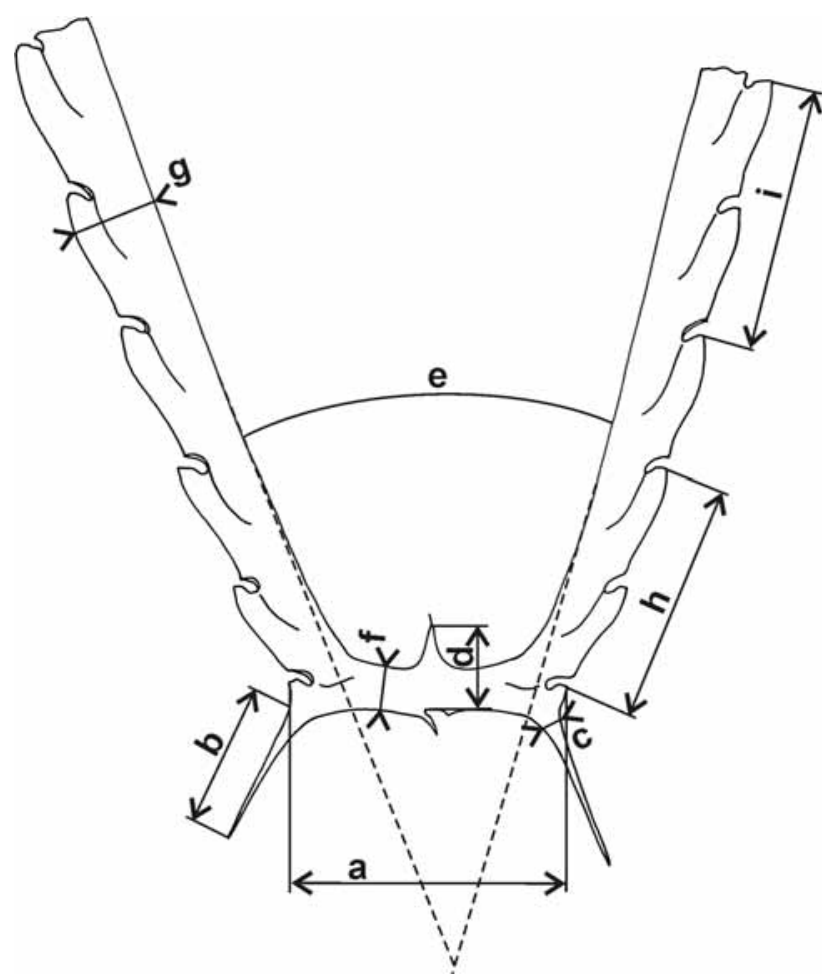

Figure 7. Some of the characters measured on dicranograptoid rhabdosomes (Dicellograptus, Pleurograptus and Diceratograptus) in this study: a - width of the axial region (distance between apertures of th $1^{1}$ and $\left.\mathrm{th} 1^{2}\right), \mathrm{b}$ - length of the basal spine, $\mathrm{c}$ - width of the basal spine, $\mathrm{d}$ - length of the sicula, e - axial angle (angle of divergence of the stipes), $\mathrm{f}$ - stipe width at th $1^{1}, \mathrm{~g}$ - stipe width at th5, h-2TRD, $\mathrm{i}-2 \mathrm{TRD}_{5}$.

dence from Nemagraptus, Amphigraptus, and Tangyagraptus suggests that a multi-stiped condition arose several times independently from a Dicellograptus-like ancestor (Finney 1985, Mu et al. 1993, Goldman, pers. comm. 2010, Bates, pers. comm. 2010). Thus, the Nemagraptidae Lapworth, 1873 does not appear to represent a monophyletic group and we include all the cladia-bearing "nemagraptids", including Pleurograptus lui, within an undivided Dicranograptoidea. Some of the characters used in systematic descriptions of dicranograptoid rhabdosomes (Dicellograptus, Pleurograptus and Diceratograptus) are shown in Fig. 7.

\section{Genus Dicellograptus Hopkinson, 1871}

Type species. - Didymograptus elegans Carruthers, 1867, p. 369 , pl. 2, fig. 16a; subsequently designated by Gurley 1896, p. 70.

Dicellograptus ornatus Elles \& Wood, 1904

Figures 8C, E, G-I, K, N, Q, 9A-C, E-G, 10V, Table 1

1904 Dicellograptus complanatus var. ornatus Elles \& Wood, pp. 140, 141, pl. 20, figs 2a, b, non fig 2c. 
Table 1. Dicellograptus ornatus. Dimensions of illustrated and other exemplary specimens (in mm).

\begin{tabular}{|c|c|c|c|c|c|c|c|c|c|c|}
\hline \multirow{2}{*}{ Specimen USNM } & \multirow{2}{*}{ Text-figure } & \multirow{2}{*}{ Axil W } & \multirow{2}{*}{ Basal spine $\mathrm{L}$} & \multicolumn{4}{|c|}{ Stipe W } & \multicolumn{3}{|c|}{ 2TRD } \\
\hline & & & & th1 & th3 & th10 & dist. & th2 & th5 & th10 \\
\hline 542819 & $8 \mathrm{C}$ & 1.7 & $>1.4$ & 0.38 & 0.55 & - & - & 1.4 & - & - \\
\hline 542758 & $8 \mathrm{E}$ & 1.7 & 0.4 & 0.28 & 0.45 & - & - & 1.5 & 2.0 & - \\
\hline 542667 & $8 \mathrm{G}, 9 \mathrm{~A}$ & 1.6 & 1.9 & 0.3 & 0.45 & 0.55 & 0.6 & 1.5 & 1.9 & - \\
\hline 542718 & $8 \mathrm{I}, 9 \mathrm{C}$ & 1.5 & $?$ & 0.27 & 0.35 & 0.55 & 0.6 & 1.55 & 1.65 & 2.0 \\
\hline 542733 & $8 \mathrm{~K}, 9 \mathrm{G}$ & 1.45 & 0.8 & 0.28 & 0.35 & 0.55 & 0.55 & 1.35 & 1.7 & 2.0 \\
\hline 542843 & $8 \mathrm{~N}, 9 \mathrm{~F}$ & 1.45 & 1.5 & 0.25 & 0.32 & 0.52 & - & 1.2 & $?$ & 1.9 \\
\hline 542759 & $8 Q$ & 1.7 & 1.2 & 0.28 & 0.4 & 0.6 & 0.6 & 1.35 & 1.75 & 2.0 \\
\hline 542764 & $10 \mathrm{~V}$ & 1.6 & $>0.5$ & 0.27 & 0.48 & 0.6 & 0.75 & 1.35 & 1.75 & 2.0 \\
\hline 542762 & $9 \mathrm{~B}$ & 1.55 & 0.5 & 0.27 & 0.4 & - & - & 1.5 & $?$ & - \\
\hline 542664 & - & 1.6 & 1.85 & 0.25 & 0.4 & 0.55 & 0.65 & 1.55 & 1.85 & 2.2 \\
\hline
\end{tabular}

1945 Dicellograptus excavatus Mu, p. 203, pl. 1a, 2.

1947 Dicellograptus complanatus var. ornatus Elles \& Wood. - Ruedemann, pp. 377, 378, pl. 62, figs 16-20.

1963 Dicellograptus complanatus ornatus Elles \& Wood. - Ross \& Berry, pp. 103, 104, pl. 6, figs 8, 12, 13, 17, 19.

1970 Dicellograptus ornatus Elles \& Wood. - Toghill, pp. 14-16, pl. 6, figs 2-4, text-fig 3a, b.

1982 Dicellograptus ornatus Elles \& Wood. - Williams, pp. 35, 36 (partim), pl. 1, fig. 7 (non figs 6, 8), text-fig. 6a-e, h (non f, g).

1984 Dicellograptus uniformis sp. n. - Li, p. 161, pl. 2, figs $15,16$.

1984 Dicellograptus cf. russoni Ruedemann. - Li, p. 160, pl. 2, fig. 12.

1984 Dicellograptus ornatus huloensis subsp. n. - Li, p. 159 , pl. 2, fig. 14 , text-fig 2 b.

1993 Dicellograptus ornatus Elles \& Wood. - Chen (in Mu et al.), p. 109, pl. 7, fig. 10; pl. 8, figs 1, 3-6, 8-11; pl. 9, figs 2-3, 5, 7-10.

2002 Dicellograptus ornatus Elles \& Wood. - Mu et al., pp. 425, 426, pl. 124, figs 1,14 .

Material and stratigraphical range. - Common species ranging from the ornatus Biozone to the pacificus Biozone in the Vinini Creek section and Monitor Range section (more than 50 rhabdosomes available, 28 rhabdosomes measured). More-or-less flattened specimens came from varied limestones, lime mudstones, mudstones and black shales.

Description. - Almost square axial region of rhabdosome is $1.45-1.95 \mathrm{~mm}$ wide between th $1^{1}$ and th $1^{2}$ apertures. Th $1^{1}$ and th $1^{2}$ horizontal to slightly declined with prominent, subapertural basal spines. Spines $<1 \mathrm{~mm}$ long in juvenile specimens, becoming $4 \mathrm{~mm}$ long and $0.26 \mathrm{~mm}$ wide spikes when mature. Sicula rarely and incompletely preserved. Stipes almost straight, with a gentle torsion, occasio- nally slight double curvature that results in slightly convex form distally. Axial angle generally $30-45^{\circ}$ (extremes $\left.20^{\circ}-47^{\circ}\right)$. Stipes $0.22-0.35 \mathrm{~mm}$ wide at th $1,0.32-0.55 \mathrm{~mm}$ wide at th3, maximum $0.55-0.65 \mathrm{~mm}$ (extremes $0.5-0.9 \mathrm{~mm}$ ) by th8-th10 but occasionally not until th15-th20. Thecae geniculate, with slightly convex ventral wall and slightly introverted and introtorted aperture facing narrow excavation that occupies one-third to half the stipe width (see Fig. 8H). 2TRD 2 : $1.2-1.6 \mathrm{~mm}, \mathrm{TTRD}_{5}$ : 1.6-2.0 mm, maximum 2TRD: $1.9-2.4 \mathrm{~mm}$ by about th10.

Remarks. - Rhabdosomes show some variation in the development of basal spines and in stipe curvature and torsion. Immature or fragmentary rhabdosomes exhibit straight stipes with axial angle of about $30-45^{\circ}$. Slight curvature and twisting of stipes is generally seen in large specimens (e.g. Fig. 8K, Q). Curved stipes are mentioned by Elles \& Wood (1904) and figured, still more pronounced, by Ross \& Berry (1963, pl. 6, figs 17, 19). Basal spines tend to elongate and thicken during the astogenetic development. On average, however, specimens from Nevada possess smaller spines than those reported from the British Isles and elsewhere.

A single, flattened, mature rhabdosome from the upper ornatus Biozone of the Martin Ridge Section possesses spiralled stipes with axial torsion. The distance between the stipes (axil $1.6 \mathrm{~mm}$ wide), stipe width $(0.6 \mathrm{~mm}$ at th10), and thecal shape and spacing (2TRD: $2.1 \mathrm{~mm}$ at th10) fall within common ranges observed in other specimens of Di. ornatus from both Vinini Creek and Martin Ridge sections. Spiralling of the stipes appears to be enhanced by unusual orientation of the rhabdosome with respect to the bedding plane, which resulted in a peculiar mode of subsequent flattening with two stipe crossings (Fig. 10V). The superficially similar species Dicellograptus complexus Davies has more tightly spiralled and narrower stipes $(\mathrm{DVW}=0.5 \mathrm{~mm})$. Specimens referred to Di. complanatus arkansasensis Ruedemann by $\mathrm{Mu}$ et al. (1993) exhibit a 
Table 2. Dicellograptus minor. Dimensions of illustrated specimens (in mm).

\begin{tabular}{|c|c|c|c|c|c|c|c|c|c|c|}
\hline \multirow{2}{*}{ Specimen USNM } & \multirow{2}{*}{ Text-figure } & \multirow{2}{*}{ Axil W } & \multirow{2}{*}{ Basal spine L } & \multicolumn{4}{|c|}{ Stipe W } & \multicolumn{3}{|c|}{ 2TRD } \\
\hline & & & & th1 & th3 & th10 & dist. & th2 & th5 & th10 \\
\hline 542797 & $8 \mathrm{~A}, 11 \mathrm{D}$ & 1.7 & 0.5 & 0.2 & 0.3 & - & - & 1.45 & 1.5 & - \\
\hline 542851 & $8 \mathrm{~B}$ & 1.85 & 0.15 & 0.24 & 0.32 & 0.4 & - & 1.5 & 2.0 & - \\
\hline 542701 & $8 \mathrm{D}, 9 \mathrm{D}$ & 1.9 & 0.45 & 0.28 & 0.38 & 0.48 & 0.5 & 1.75 & 1.9 & 2,3 \\
\hline 542768 & $8 \mathrm{~J}$ & 1.45 & 0.55 & 0.23 & 0.25 & 0.55 & 0.55 & 1.55 & 1.75 & - \\
\hline
\end{tabular}

dorsoventral width and thecal spacing identical to that of Di. ornatus along with moderately developed basal spines. The thecae differ slightly in being more nearly climacograptid and the stipes appear to have a more strongly upward growth and cross more rapidly (generally by $10 \mathrm{~mm}$ from the proximal end) after which most seem to remain uncrossed. This form may fall within the range of intraspecific variation of Di. ornatus but the slight differences in thecal form and stipe arrangement require restudy of populations from the Wufeng Formation to determine how these variations are distributed among specimens before it is possible to determine whether they are likely to have been conspecific.

\section{Dicellograptus minor Toghill, 1970}

Figures 8A, B, D, J, 9D, 11D, Table 2

1970 Dicellograptus ornatus minor subsp. nov.; Toghill, pp. 16,17 , pl. 6 , figs $5-7$; text-figs $3 \mathrm{c}-\mathrm{g}$.

1980 Dicellograptus ornatus minor Toghill, 1970. Koren' \& Sobolevskaya, p. 105, pl. 26, figs 4, 5; text-fig. 33.

1982 Dicellograptus minor Toghill. - Williams, p. 37, pl. 2, figs 9-15.

1987 Dicellograptus minor Toghill. - Williams, p. 75, figs $4 \mathrm{C}, \mathrm{D}$, ?A.

Material and stratigraphical range. - Common species that occurs from the ornatus Zone to the upper part of the pacificus Zone in both the Vinini Creek Section and Martin Ridge section. 12 of more than 30 specimens have been measured in detail. Generally flattened specimens came from varied limestones, lime mudstones, mudstones and black shales.

Description. - Minute rhabdosome with relatively wide axial region; straight to slightly outwardly curved stipes diverge at $100-130^{\circ}$ (observed minimum $70^{\circ}$ ). Sicula rarely discernible; apertural width $0.15 \mathrm{~mm}$. Th $1^{1}$ and $1^{2}$ slightly declined, with $0.3-0.6 \mathrm{~mm}$ long subapertural spines. Distance between th $1^{1}$ and th $1^{2}$ apertures $1.45-2.0 \mathrm{~mm}$. Stipes $0.2-0.3 \mathrm{~mm}$ wide at th1, 0.22-0.4 $\mathrm{mm}$ at th $3,0.35-0.4 \mathrm{~mm}$ (up to $0.48 \mathrm{~mm}$ ) at th10 and $\sim 0.5 \mathrm{~mm}$ most distally. Distal thecae widely spaced; 2TRD 1.8-2.1 mm (extreme
$2.6 \mathrm{~mm}$ ). $2 \mathrm{TRD}_{2}: 1.2-1.75 \mathrm{~mm}$ and $1.5-2 \mathrm{~mm}$ at th5. Supragenicular thecal walls generally straight and long compared to stipe width and small apertural excavations that occupy about half of the stipe width. Thecal apertures are normal to stipe axis to very slightly introverted.

Remarks. - Dicellograptus minor is readily distinguishable from other coeval dicellograptids by its slender, highly divergent stipes and slender tubular metathecae with negligible apertural introversion. Small basal spines and slight but abrupt dorsal bend of the stipe after the th1 aperture differentiate Di. minor from immature specimens of Pleurograptus lui that lack metacladia. The latter species commonly exhibits a long, unresorbed sicula. Stipe fragments of $P l$. lui $\mathrm{Mu}, 1950$ are very similar to Di. minor but usually exhibit slightly inclined supragenicular ventral thecal walls and more introverted apertures.

\section{Dicellograptus tumidus Chen, 1978}

Figures 10N, R, S, 11B, J, 12L

1978 Dicellograptus tumidus; Chen (in Stratigraphy Research Group of the Yangtze Gorges, Hubei Bureau of Geology ed.), p. 198, pl. 45, figs 2, 3.

1993 Dicellograptus tumidus Chen. - Chen (in Mu et al.), pp. 113, 114, pl. 10, figs 6, 7; pl. 11, figs $2,7,10,11$; pl. 12 , figs 4,7 .

2002 Dicellograptus tumidus Chen. - Mu et al., p. 430, pl. 126 , figs 8,9 .

Material and stratigraphical range. - Rare species of the pacificus Zone at Vinini Creek Section. One flattened specimen originates from black shale at $10.30 \mathrm{~m}$, one from $10.8 \mathrm{~m}$ and four specimens from $11.70 \mathrm{~m}$ (5 specimens measured).

Description. - Rather narrow axil with sub-horizontal th $1^{1}$ and th $1^{2}$ with tiny, $0.15-0.25 \mathrm{~mm}$ long subapertural basal spines. Apertures of th $1^{1}$ and th1 。 1.3-1.7 mm apart. Sicula not preserved. Stipes with low initial angle of divergence, $15-30^{\circ}$, slight axial torsion and gentle ventral curvature beginning at $\sim$ th 3 , increasing stipe divergence to $60^{\circ}$. Stipes $0.26-0.4 \mathrm{~mm}$ wide at th1, 0.42-0.55 at th 3 and distal max width $0.65-0.7 \mathrm{~mm}$. Thecae strongly geniculate, with 
Table 3. Dicellograptus turgidus. Dimensions of illustrated specimens (in mm).

\begin{tabular}{|c|c|c|c|c|c|c|c|c|c|c|}
\hline \multirow{2}{*}{ Specimen USNM } & \multirow{2}{*}{ Text-figure } & \multirow{2}{*}{ Axil W } & \multirow{2}{*}{ Basal spine L } & \multicolumn{4}{|c|}{ Stipe W } & \multicolumn{3}{|c|}{ 2TRD } \\
\hline & & & & th1 & th 3 & th10 & dist. & th2 & th5 & th10 \\
\hline 542708 & $10 \mathrm{G}$ & 1.5 & 3.4 & 0.4 & $?$ & 0.9 & - & 1.5 & 1.5 & - \\
\hline 542794 & 10I, 11I & 1.7 & 2.75 & 0.55 & 0.8 & 0.7 & 0.85 & 1.2 & $?$ & 2.3 \\
\hline 542859 & $10 \mathrm{~J}, 12 \mathrm{O}$ & 1.55 & 3.45 & 0.4 & 0.55 & 0.8 & - & 1.2 & 1.75 & - \\
\hline
\end{tabular}

straight or slightly convex supragenicular wall and rather shallow apertural excavations; thecal apertures are horizontal to introverted with lateral lappets. 2TRD $1.2-1.6 \mathrm{~mm}$ at th2, $1.4-1.85 \mathrm{~mm}$ at th5 and up to $2 \mathrm{~mm}$ at th10.

Remarks. - Chen (1978) distinguished Di. tumidus from Dicellograptus turgidus Mu by its slightly diverging stipes with early but gentle ventral curvature. The axial membrane and robust asymmetrical basal spines of Di. turgidus are missing in Di. tumidus. However, small rhabdosomes of the two species, composed only of several thecae, can hardly be told apart (cf. Figs 10K, 11B). Mu et al. (1993) considered Di. tumidus as a direct ancestor of Di. turgidus. In Vinini Creek Di. tumidus made its lowest occurrence two sampling levels below lowermost Di. turgidus and their short stratigraphic ranges overlap for the most part.

\section{Dicellograptus turgidus Mu, 1963a}

Figures 10G, I-K, 11I, 12O, Table 3

1963a Dicellograptus turgidus; Mu, p. 371, text-fig. 13a.

1978 Dicellograptus turgidus Mu. - Wang \& Zhao, pp. 628, 629, pl. 203, figs 11, 12.

1978 Dicellograptus turgidus membranaceus; Chen (in Ye), p. 449, pl. 170, fig. 15.

1982 Dicellograptus ornatus Elles \& Wood. - Williams, p. 35 (partim), pl. 1, fig. 8.

1983 Diceratograptus mirus Mu. - Mu et al., pl. 1, fig. 7.

1983 Dicellograptus turgidus membranaceus Chen; Chen, p. 419 , pl. 153 , fig. 7 .

1993 Dicellograptus turgidus $\mathrm{Mu}$ - - Chen (in $\mathrm{Mu}$ et al.), p. 114, pl. 12, figs 2, 3, 5, 6, 8, 10 .

2002 Dicellograptus turgidus Mu. - Mu et al., pp. 430, 431, pl. 126, figs 6, 7.
2002 Dicellograptus turgidus membranaceus Chen. - Mu et al., p. 431, figs 1, 2 .

Material and stratigraphical range. - Rare species of the pacificus Subzone at Vinini Creek section. Three flattened specimens originate from black shale at $10.30 \mathrm{~m}$ and one specimen from $11.70 \mathrm{~m}$.

Description. - Axil angular, 1.4-1.7 mm wide at the level of the first thecal pair apertures. Sicula with tiny virgella, apex rarely preserved. Thl ${ }^{1}$ and th $1^{2}$ horizontal for much of their length and bear subapertural basal spines. One spine very large and robust, with secondary thickening on its ventral side (see Fig. 10G, I, J), the opposite one much less prominent. Reclined stipes robust, ventrally flexed at the level of th5-7. Initial axial angle $10-15^{\circ}$ opens to $100-140^{\circ}$ at this level. Distalwards stipes slightly dorsally reflexed at th14-15 and exhibit gentle axial torsion. Membrane present between stipes proximally, reaching up to the aperture of th5-6. Thecae geniculate, with gently convex supragenicular wall and apertures introverted into small excavations. Small genicular hoods visible on proximal thecae of some specimens. Stipe width $0.4-0.55$ at first pair, $0.55-0.8 \mathrm{~mm}$ at th3, $0.65-0.9 \mathrm{~mm}$ at th10 and about $0.85 \mathrm{~mm}$ distally. Maximum preserved stipe length $22.5 \mathrm{~mm}$. Proximal thecae densely spaced, strongly overlapping. $2 \mathrm{TRD}_{2}: 1.2-1.5 \mathrm{~mm}, 2 \mathrm{TRD}_{5}$ : $1.5-1.75 \mathrm{~mm}$. Distal thecae number $8.5-9.5$ in $10 \mathrm{~mm}$ with 2TRD: 2.1-2.4 mm.

Remarks. - The most distinctive feature of. Di. turgidus $\mathrm{Mu}$ is the combination of robust stipes, interconnected by an axial membrane up to the level of their abrupt ventral curvature, with large, asymmetrically developed basal spines. Williams (1982, pl. 1, fig. 8) identified specimens of Di. turgidus as mature specimens of Di. ornatus but the

Figure 8. A, B, D, J - Dicellograptus minor Toghill, 1970: A - USNM 542797, level $10.30 \mathrm{~m}$; B - USNM 542851, $11.70 \mathrm{~m}$; D - USNM 542701, level 11.70 m; J - USNM 542768, level MR 105.2 m. • C, E, G-I, K, N, Q - Dicellograptus ornatus Elles \& Wood, 1904: C - USNM 542819 , level 27.70 m; E - USNM 542758, level MR $96.13 \mathrm{~m}$; G - USNM 542667, level $6.10 \mathrm{~m}$; H - USNM 542735 (thecae in detail), level $3.00 \mathrm{~m}$; I - USNM 542718, level 2.95 m; K - USNM 542733, level 3.00 m; N - USNM 542843, level 3.00 m; Q - USNM 542759, level MR 96.13 m. • F, L, M, O, P, R - Pleurograptus lui Mu, 1950: F - USNM 542734, level 3.00 m; L - USNM 542760, level MR 96.13 m; M - USNM 542765a, P - USNM 542765b, level MR 96.13 m; O - USNM 542751, level MR 86.00 m; R - USNM 542656, level 4.40 m (preserved in relief). - USNM 542656, 542667, 542718, 542733, 542734, $542735,542751,542758,542759,542760,542765 \mathrm{a}$, b and 542843 from the ornatus Biozone, USNM 542701, 542768, 542797 and USNM 542851 from the pacificus Biozone and sample USNM 542819 from the persculptus Biozone. A-D, F-I, K, N, R from the Vinini Creek section, E, J, L, M, O-Q from the Martin Ridge section. All figures $\times 6$ (common scale bar equals $1 \mathrm{~mm}$ ), except $\mathrm{H}, \mathrm{R} \times 10$ (two respective scale bars equal $1 \mathrm{~mm}$ ). 
Petr Štorch et al. • Uppermost Ordovician graptolites of north-central Nevada
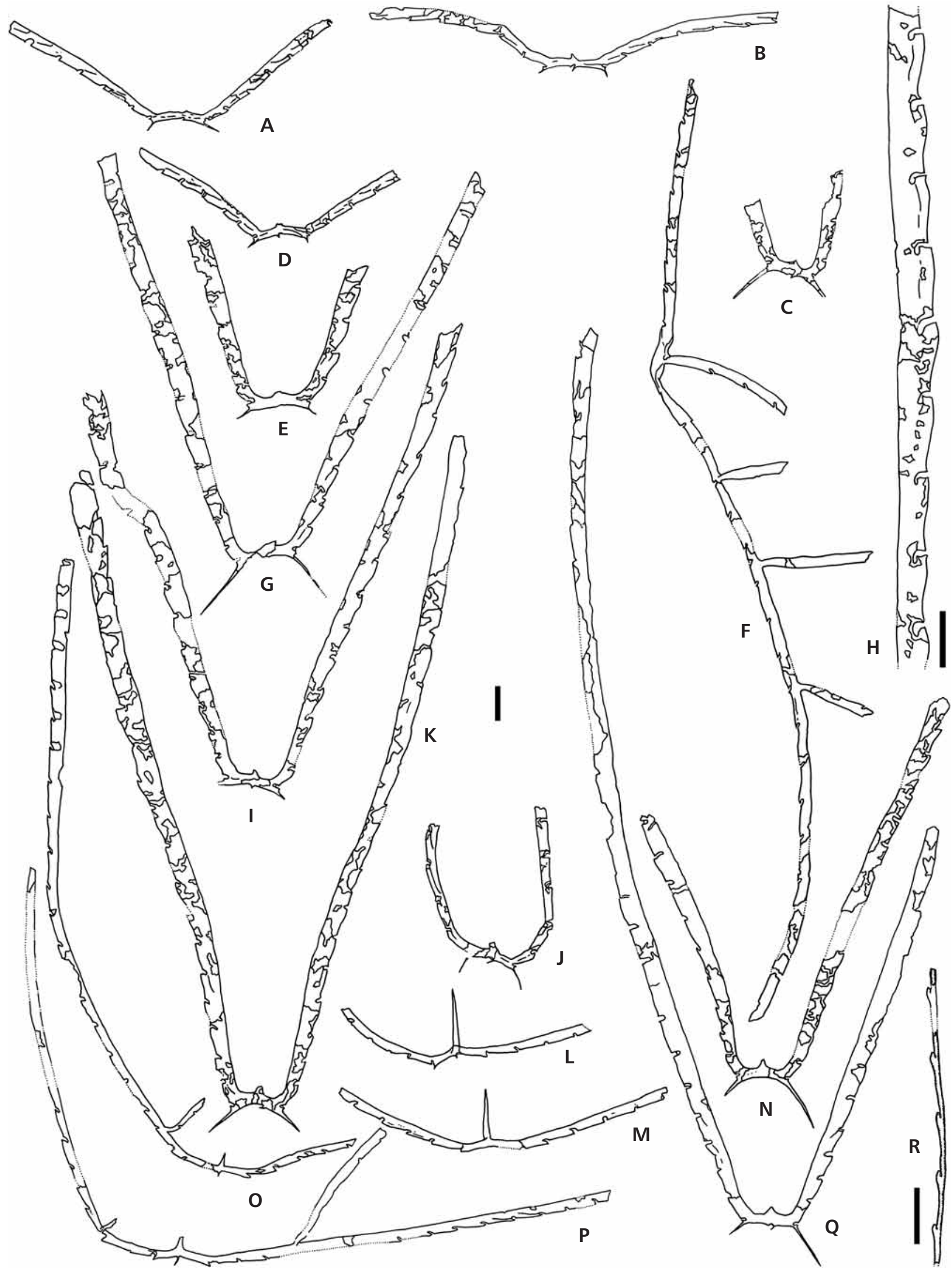
axial membrane and abrupt ventral curvature of the relatively wide stipes are formed early in the astogeny of $D i$. turgidus and are not gerontic features. The basal spine originating from th $1^{1}$ is long and robust, sabre shaped, and exhibits further thickening during astogenetic development. The basal spine on th $1^{2}$ remains considerably smaller in mature rhabdosomes from Vinini Creek section. The axial membrane and early astogeny of Dicellograptus turgidus membranaceus Chen, 1978 are fully consistent with diagnostic characters of the earlier described $D$. turgidus Mu, 1983a.

\section{Dicellograptus mirabilis Mu \& Chen, 1993}

Figures 10T, 11G

1982 Dicellograptus ornatus Elles \& Wood, 1904. - Williams, pp. 35, 36 (partim), ?pl. 1, fig. 6; fig. 6f, g.

1993 Dicellograptus mirabilis sp. nov.; Mu \& Chen (in Mu et al.), pp. 112, 326; pl. 10, figs 1-3, 10.

Material and stratigraphical range. - The two flattened specimens at our disposal came from black shale of the $p a-$ cificus Zone at $10.30 \mathrm{~m}$ of the Vinini Creek section.

Description. - Two robust rhabdosomes, with large, thick basal spines and broad, sub-rounded axil. The axil 2.2-2.55 $\mathrm{mm}$ wide at the level of th $1^{1}$ and th $1^{2}$ apertures, strengthened by axial membrane attaining the level of the second thecal apertures. Basal spines $>6.4 \mathrm{~mm}$ long, $\sim 0.6 \mathrm{~mm}$ wide near their base. Sicula not identified. Stipes straight proximally and slightly convex distally. The longest stipe available measures $24 \mathrm{~mm}$. The axial angle 40 and $45^{\circ}$ in our specimens. Stipes $0.6-0.7 \mathrm{~mm}$ wide at th3, $0.8 \mathrm{~mm}$ at th10 and thereafter attain the maximum width of $0.9 \mathrm{~mm}$. Thecae geniculate, with slightly convex ventral wall and slightly introverted and introtorted aperture facing narrow excavation that occupies one-third stipe width. $2 \mathrm{TRD}_{2}: 1.6 \mathrm{~mm}, 2 \mathrm{TRD}_{5}$ and $2 \mathrm{TRD}_{10}: 2.0 \mathrm{~mm}$, maximum 2TRD: $2.3 \mathrm{~mm}$ distally.

Remarks. - This rare form may be readily distinguished from $D i$. ornatus by its broad axil, very large and thick basal spines and greater DVW of the stipes. Its broad axil, axial membrane and wide stipes, in turn, resemble Chinese specimens of Dicellograptus mirabilis $\mathrm{Mu} \&$ Chen, 1993, although the spines are larger than those reported by $\mathrm{Mu}$ et al. (1993). Di. mirabilis is known so far from Dob's Linn, Scotland (specimens formerly assigned to Di. ornatus by Williams 1982) and from about the same stratigraphic level in the Wufeng Formation, China. Large basal spines and axial membrane are widely considered diagnostic features of Dicellograptus turgidus $\mathrm{Mu}$, 1963a, which is readily distinguishable, however, from Di. mirabilis by abrupt ventral curvature of the stipes, larger axial membrane at comparable astogenetic stages, more densely spaced proximal thecae and, according to our observation, the strongly asymmetric development of the basal spines.

\section{Dicellograptus cf. anceps (Nicholson, 1867)} Figures 10Q, 12M
cf. 1867 Didymograpsus anceps; Nicholson, p. 110, pl. 7, figs $18-20$.
cf. 1904 Dicellograptus anceps (Nicholson). - Elles \& Wood, pp. 141-143, pl. 20, figs 3a-c.

Material and stratigraphical range. - A single proximal fragment from the Vinini Creek section $(7.75 \mathrm{~m})$. Low relief preservation in sparry limestone.

Remarks. - A single, slightly dorsally curved, $8.5 \mathrm{~mm}$ long and $0.9 \mathrm{~mm}$ wide near-proximal stipe fragment exhibits the same thecal spacing ( 5.5 thecae in $5 \mathrm{~mm}$ ) and spinosity as does $\mathrm{Di}$. anceps (Nicholson). The thecae are slightly introverted into narrow apertural excavations that occupy about one-third the stipe width. Considerable convexity of the supragenicular thecal wall is accentuated by $0.2-0.3 \mathrm{~mm}$ long mesial spine in all thecae preserved. The DVW lies near the maximum measured in the corresponding growth stage of Di. anceps. The closely similar Di. laticeps Štorch, 1989 differs from $D i$. anceps mainly in having a broader, rather rounded axil and more diverging stipes. Neither of the diagnostic features can be seen in our specimen, which, therefore, is preferably left in open nomenclature. Also, Dicellograptus gravis Keble \& Harris, 1925 possesses convex supragenicular thecal walls with mesial spines and dorsoventral width of about $1 \mathrm{~mm}$. Lower thecal spacing (8-9 thecae in $10 \mathrm{~mm}$ ) and its occurrence in significantly earlier strata (lower Di. complanatus Biozone), however, suggest that our specimens do not belong to this species.

Figure 9. A-C, E-G - Dicellograptus ornatus Elles \& Wood, 1904: A - USNM 542667, level 6.10 m; B - USNM 542762, level MR 96.13 m; C - USNM 542718, level 2.95 m; E - USNM 542735 (thecae in detail), level 3.00 m; F - USNM 542843, level 3.00 m; G - USNM 542733, level 3.00 m. - D - Dicellograptus minor Toghill, 1970: USNM 542701, level 11.70 m. • USNM 542667, 542718, 542733, 542735, 542762 and 542843 from the ornatus Biozone and USNM 542701 from the pacificus Biozone. All specimens from the Vinini Creek section, except USNM 542762 from the Martin Ridge section. Figures A, C, F, G ×6, figures B, D, E $\times 10$. Scale bars equal $1 \mathrm{~mm}$. 

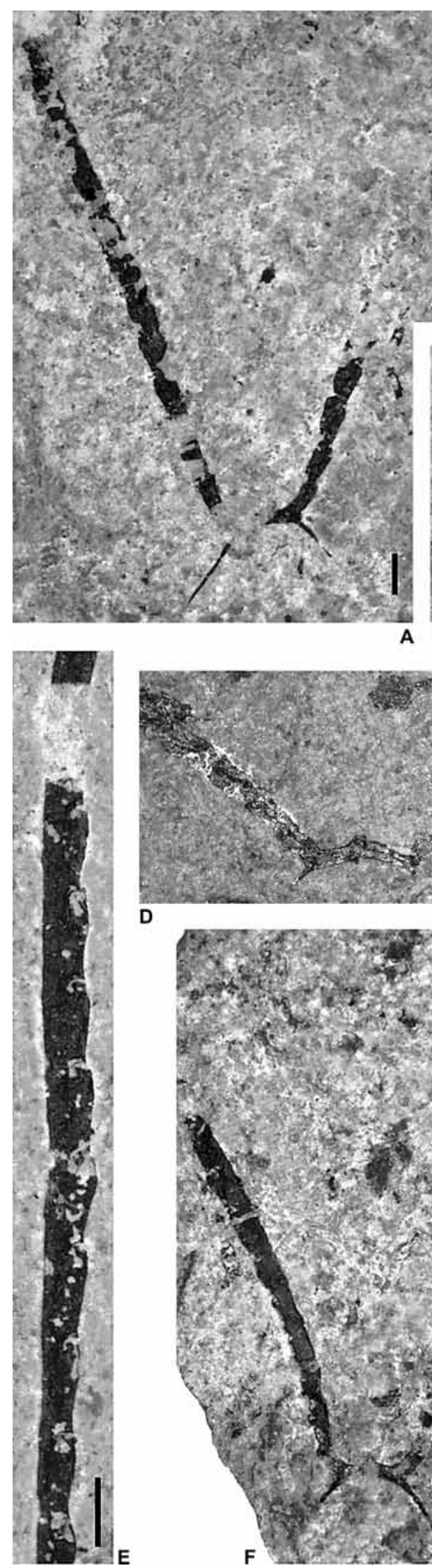

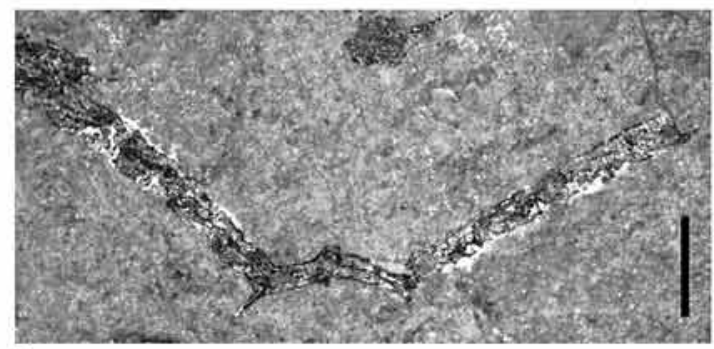

D

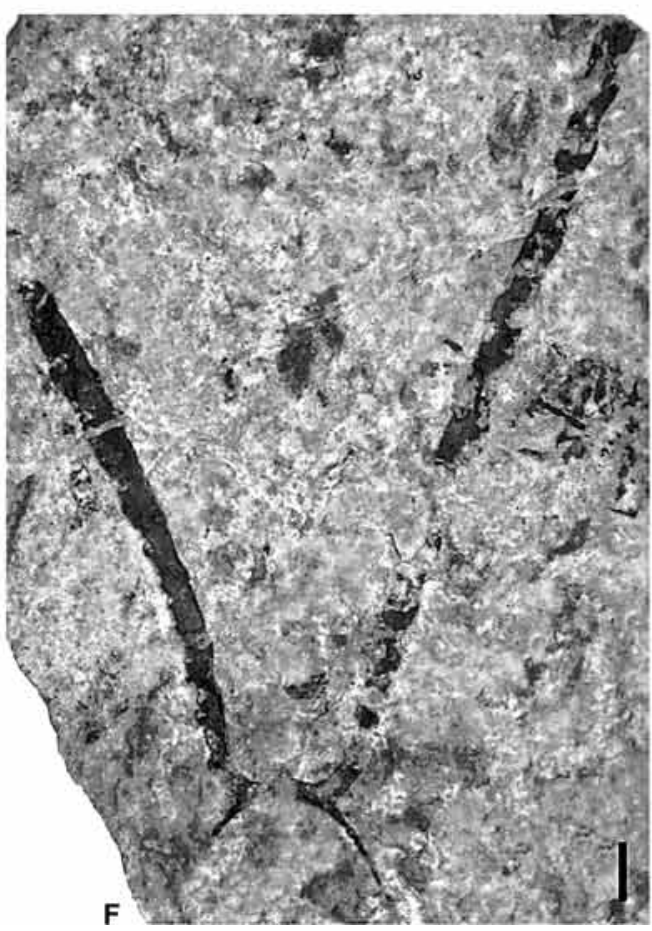

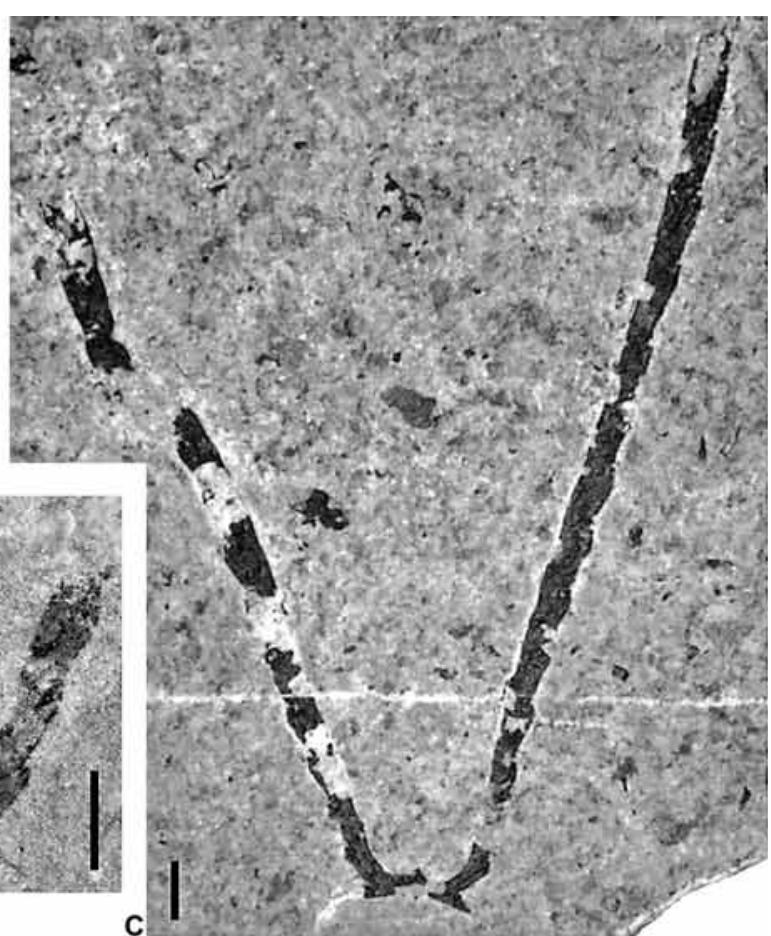

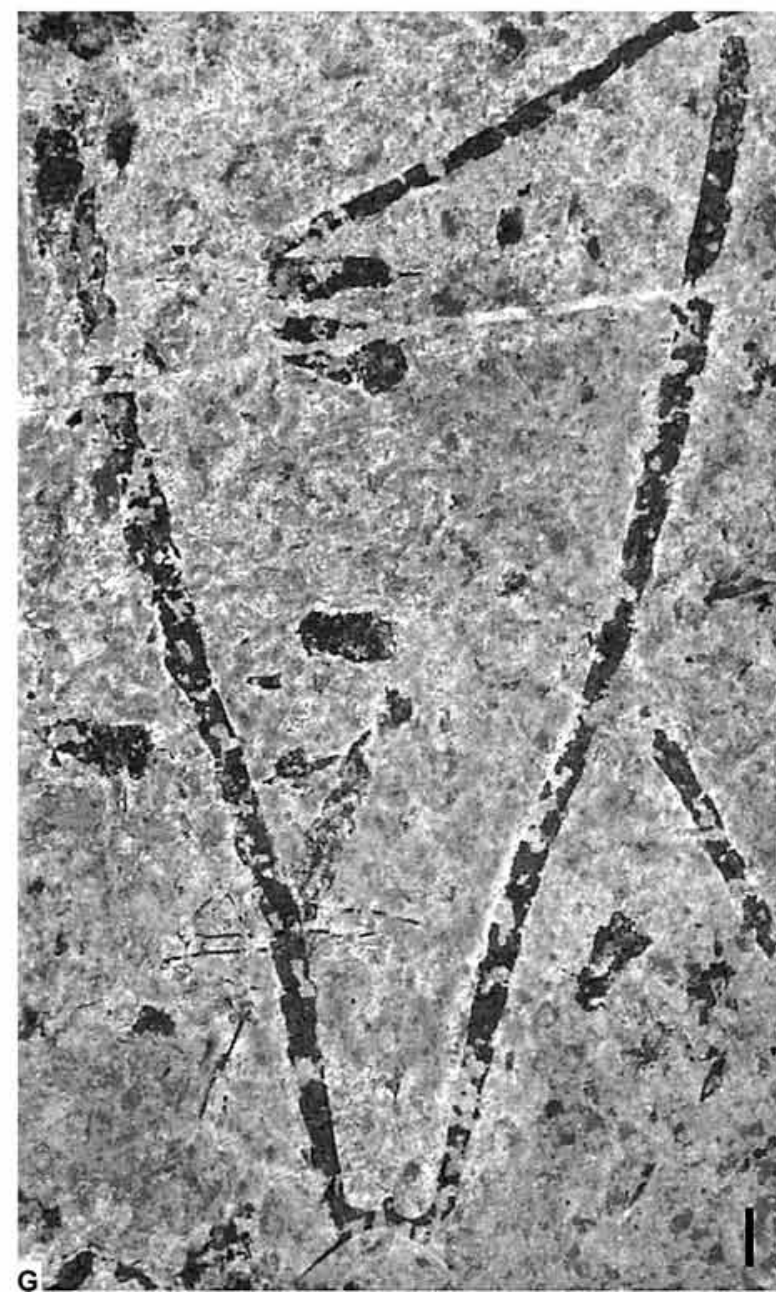




\section{Dicellograptus cf. complanatus Lapworth, 1880}

Figures 10A, B, H, 11A

cf. 1980 Dicellograptus complanatus Lapworth, 1880. Koren' et al., pp. 101-103 (partim), pl. 25, figs 5, 6, 8, 9; text-fig. 31б, в, и, к, p, ж.

1993 Dicellograptus cf. complanatus Lapworth. - Chen (in Mu et al.), pp. 108, 109, pl. 7, figs 4, 11-13; pl. 8, figs $2,7,12,13$; pl. 9 , figs 1,4 .

Material and stratigraphical range. - Four flattened rhabdosomes preserved in limestones and lime-mudstones of the ornatus Zone from Vinini Creek section.

Remarks. - The present specimens differ from Di. complanatus, as described and figured by Elles \& Wood (1904), Toghill (1970) and Williams (1982), in having broader, rather subangular than rounded axil and more pronounced basal spines. Proximal development and width of the stipes likely match those of Di. ornatus. Koren' et al. (1983) recorded this form in NE Siberia, assigned it to Di. complanatus Lapworth, but pointed out its similarity to Di. ornatus Elles \& Wood. Mu et al. (1993) left this morphologically intermediate form under open nomenclature and, due to insufficient material on our disposal, we follow their view. Our specimens have been distinguished from $D i$. ornatus by their smaller basal spines at corresponding stage of astogenetic development, by its less angular axil and more pronounced increase of the dorsoventral width in the proximal and mesial parts of the stipe. Thecal details have been largely obscured and are not useful for species recognition.

\section{Genus Diceratograptus Mu, 1963a}

Type species. - Diceratograptus mirus Mu, 1963a, p. 367, text-fig. 13b; original designation.

\section{Diceratograptus mirus Mu, 1963a}

Figures 10C-F, 12T

1963a Diceratograptus mirus; Mu, p. 367, text-fig. 13.
1974 Diceratograptus mirus Mu. - Nanjing Institute of Geology and Palaeontology ed., p. 159, pl. 70, fig. 12.

1984 Diceratograptus mirus Mu. - Mu \& Lin, p. 51, pl. 2, figs 6,7 .

1984 Diceratograptus cf. mirus Mu. - Chen \& Lenz, pp. 255, 256, text-fig. 1a-d.

1984 Diceratograptus mirus anhuiensis G.S. Xia. - Li, pl. 9, figs 1,2 .

1993 Diceratograptus mirus Mu. - Chen (in Mu et al.), p. 119 , pl. 17, figs 7, 8, pl. 18, fig. 4, pl. 19, figs 1-7.

2002 Diceratograptus mirus Mu. - Mu et al., p. 431, pl. 126, figs $1,2$.

2005a Diceratograptus mirus Mu, 1963. - Chen et al., p. 241 , text-fig. $3 \mathrm{E}$.

2006 Diceratograptus mirus Mu. - Fu et al., text-fig. 4.2, figs $1-3$.

Material and stratigraphical range. - Rare species of the pacificus Biozone at Vinini Creek section. Three of five flattened specimens originate from brown lime mudstone at $15.9 \mathrm{~m}$, one from $17.9 \mathrm{~m}$ and one specimen from $19.1 \mathrm{~m}$.

Description. - Stipes initially upward from quadrate axil with a minimum $0-5^{\circ}$ angle of divergence. Axil $1.5 \mathrm{~mm}$ wide at the level of th $1^{1}-1^{2}$ apertures. Sicula at least $1.6 \mathrm{~mm}$ long, though commonly obscured by a tissue that connected stipes in the parallel-sided proximal portion of the rhabdosome. Th11-1, horizontal and posses small, subapertural spines. Tiny subapertural spine also present on th2 in one specimen. Cordate-subtriangular lumen between the stipes exposes the sicula but it is often filled by a membrane (Fig. 10F). Tip of the lumen attains the level of about th2-th3 aperture. Then the stipes firmly connected along dorsal side of very elongate thecae, forming a short biserial section up to $7^{\text {th }}-8^{\text {th }}$ thecal pair (3.5-5 mm long), where stipes again diverge. Proximal and mesial thecae strongly geniculate, overlapping for more than half their length. Ventral supragenicular walls straight; introverted thecal apertures face into deep excavations that occupy one-third to half rhabdosome width. Proximal 2TRD 1.5-1.6 mm. Distal parts of the stipes not been preserved in our specimens.

Figure 10. A, B, H - Dicellograptus cf. complanatus Lapworth, 1880: A - USNM 542822, level 2.40 m; B - USNM 542678, level 7.50 m; H - USNM 542823, level 8.70 m. • C-F, O - Diceratograptus mirus Mu, 1963: C - USNM 542824a, D - USNM 542824b, E - USNM 542824c, level 15.90 m; F - USNM 542789, level 18.00 m; O - USNM 542808, level 17.90 m. • G, I-K - Dicellograptus turgidus Mu, 1963: G - USNM 542708, level 11.70 m; I - USNM 542794, level 10.30 m; J - USNM 542859, level 10.30 m; K - USNM 542825 (juvenile rhabdosome), level 10.75 m. • L - Parareteograptus parvus Mu, 1982: USNM 542801, level 10.30 m. • N, R, S - Dicellograptus tumidus Chen, 1978: N - USNM 542834, level 11.70 m; R - USNM 542700, level 11.70 m; S - USNM 542673, level 9.20 m. • M, P, U, W - Parareteograptus turgidus Mu, 1993: M - USNM 542724, level 11.70 m; P - USNM 542695, level 10.80 m; U - USNM 542852, level 11.70 m; W - USNM 542703, level 11.70 m. • Q - Dicellograptus cf. anceps (Nicholson, 1867): USNM 542683, level $7.75 \mathrm{~m} . \bullet \mathrm{S}$ - Dicellograptus mirabilis Mu \& Chen, 1993: USNM 542795, level $10.30 \mathrm{~m}$. • V - Dicellograptus ornatus Elles \& Wood, 1904: USNM 542764, level MR 96.13 m. All samples from the pacificus Biozone, except USNM 542678, 542683, 542764 and 542822 from the ornatus Biozone. All specimens from the Vinini Creek section, except USNM 542764 from the Martin Ridge section. All figures $\times 6$ (common scale bar equals $1 \mathrm{~mm}$ ), except $\mathrm{V} \times 3$ (assigned scale bar equals $1 \mathrm{~mm}$ ). 
Petr Štorch et al. • Uppermost Ordovician graptolites of north-central Nevada

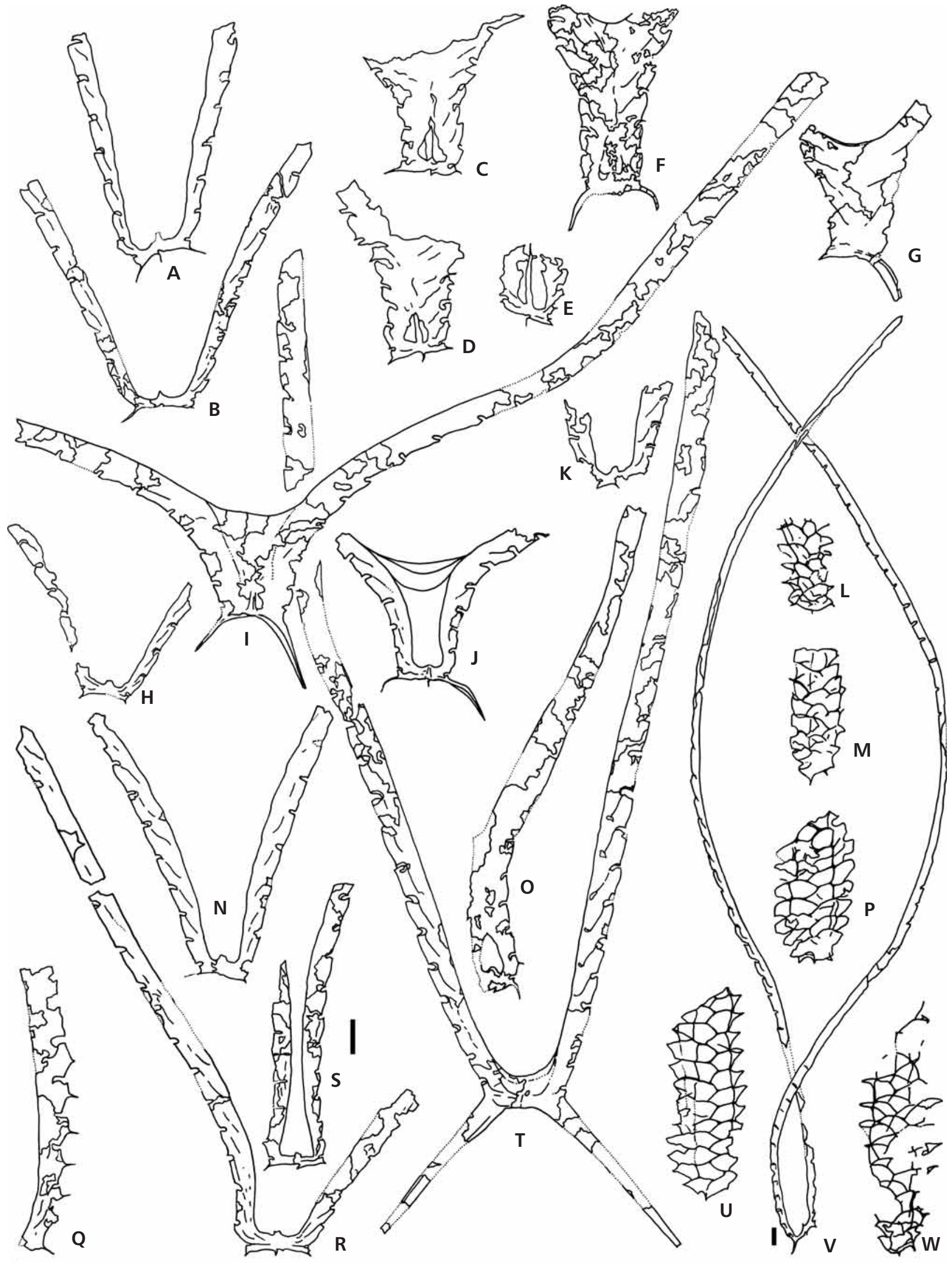


Table 4. Pleurograptus lui. Dimensions of illustrated specimens (in mm).

\begin{tabular}{|c|c|c|c|c|c|c|c|c|c|}
\hline \multirow{2}{*}{ Specimen USNM } & \multirow{2}{*}{ Text-figure } & \multirow{2}{*}{ Sicula L } & \multicolumn{4}{|c|}{ Stipe W } & \multicolumn{3}{|c|}{ 2TRD } \\
\hline & & & th1 & th5 & dist. prim stipe & dist. second stipe & th2 & dist. prim stipe & dist. second stipe \\
\hline 542734 & $8 \mathrm{~F}, 11 \mathrm{C}$ & $?$ & $?$ & $?$ & 0.35 & 0.4 & $?$ & 2.1 & 2.0 \\
\hline 542760 & $8 \mathrm{~L}$ & 1.75 & 0.18 & 0.2 & - & - & 1.6 & - & - \\
\hline $542765 a$ & $8 \mathrm{M}, 11 \mathrm{~F}$ & 1.4 & 0.23 & 0.3 & - & - & 1.6 & - & - \\
\hline $542765 b$ & $8 \mathrm{P}$ & res. & 0.25 & 0.28 & 0.3 & 0.55 & 1.6 & 2.15 & $?$ \\
\hline 542751 & $9 \mathrm{P}$ & res. & 0.22 & 0.25 & 0.42 & - & 1.45 & 1.75 & - \\
\hline
\end{tabular}

Remarks. - Until recently this unusual species had only been reported from outside China by Chen \& Lenz (1984), who discovered rare specimens in the northern Yukon. It had not been found in earlier collections at Vinini Creek but has subsequently been discovered not only here but also in the Phi Kappa Formation of Idaho (Goldman et al. 2007a) and at an additional site in the Yukon (the Blackstone River section, see LaPorte et al. 2009). Thus, although uncommon, the species was widely distributed along the Cordilleran margin of Laurentia in addition to its occurrence in South China, where it is confined to a very short interval in the uppermost pacificus Biozone, where it serves as the index taxon for the Dc. mirus Subzone. Either the species appears slightly earlier in the Vinini and Blackstone River sections (about mid way through the pacificus Biozone) or the upper part of that zone is somewhat expanded here relative to that interval in South China.

\section{Genus Pleurograptus Nicholson, 1867}

Type species. - Cladograptus linearis Carruthers, 1858, p. 467 , text-fig. 1 , pl. 2 , fig. $16 \mathrm{a}$; original designation.

\section{Pleurograptus lui $\mathrm{Mu}, 1950$}

Figures 8F, L, M, O, P, R, 11C, E, F, H, Table 4

1950 Pleurograptus lui; Mu, p. 3, figs 2-4.

1974 Pleurograptus lui Mu. - Nanjing Institute of Geology and Palaeontology ed., p. 158, pl. 70, fig. 8.

1982 Pleurograptus lui Mu, 1950. - Williams, pp. 33, 34, pl. 2, figs $1-5$, text-fig. 4.

1993 Pleurograptus lui Mu. - Mu et al., p. 95, pl. 5, figs 2, $3,7$.
Material and stratigraphical range. - More than thirty flattened, more-or-less fragmentary rhabdosomes, including 6 juvenile specimens without metacladia and one fragment preserved in relief (16 specimens measured). The collection originates from mudstones, lime mudstones and muddy limestones of the ornatus Biozone and lowermost part of the pacificus Biozone of the Vinini Creek and Monitor Range sections.

Description. - Rhabdosome consists of two slightly reclined stipes with one or more $(\max 4)$ lateral branches - metacladia - developed in mature specimens. Th $1^{1}$ and $1^{2}$ slightly declined before subsequently becoming slightly reclined at which point stipes diverge at $140^{\circ}-170^{\circ}$. The most mature rhabdosome (Figs 8F, 11C) exhibits broad ventral curvature of the stipe. Metacladia appear to extend from dorsal side of stipe but arise from the lateral part of the thecal aperture as in Nemagraptus (Finney 1985). Sicula up to $1.7 \mathrm{~mm}$ long with apertural width of $0.12-0.2 \mathrm{~mm}$ in flattened material. One specimen possesses $0.4 \mathrm{~mm}$ long virgella. Slender, elongated thecae with gently inclined supragenicular ventral walls do not exceed much parallel-sided outline of stipe. Introverted thecal apertures partly overlap shallow excavations that occupy one-third to two-fifths of stipe width. Thecal geniculation varies according to preservation and mode of the rhabdosome flattening. Th $1^{1}$ and $1^{2}$ with tiny subapertural spine. Primary stipes (procladia) $0.18-0.25 \mathrm{~mm}$ wide at th1 and $0.2-0.3 \mathrm{~mm}$ wide at th3; maximum distal width $0.22-0.42 \mathrm{~mm}$, depending on preservation (e.g. Fig. 8L, M, O, P). Metacladia attain maximum width of $0.22-0.45 \mathrm{~mm}$. 2TRD: $1.45-1.9 \mathrm{~mm}$ at th2 of the primary stipe whereas distal thecae number $\sim 10$ in $10 \mathrm{~mm}\left(2 \mathrm{TRD}_{\text {dist }}: 1.75-2.3 \mathrm{~mm}\right)$. Metacladia with similar thecal density; 2TRD: 1.75-2.6 mm.

Figure 11. A - Dicellograptus cf. complanatus Lapworth, 1880: USNM 542678, level 7.50 m. • B, J - Dicellograptus tumidus Chen, 1978: B - USNM 542700, level 11.70 m; J - USNM 542834, level 11.70 m. • C, E, F, H - Pleurograptus lui Mu, 1950: C - USNM 542734, level 3.00 m; E - USNM 542659, branching and thecal apertures in flattened specimen, level $4.40 \mathrm{~m}$; F - USNM 542765a, level MR 96.13 m; H - USNM 542656, thecae in subscalariform view, preserved in relief, level $4.40 \mathrm{~m}$. • D - Dicellograptus minor Toghill, 1970; USNM 542797, level 10.30 m. • G - Dicellograptus mirabilis Mu \& Chen, 1993: USNM 542795, level 10.30 m. • I - Dicellograptus turgidus Mu, 1963: USNM 542794, level 10.30 m. • USNM 542656, 542659, 542678, 542734 and 542765a from the ornatus Biozone, USNM 542700, 542794, 542795, 542797 and 542834 from the pacificus Biozone. All specimens from the Vinini Creek section, except USNM 542765a from the Martin Ridge section. Figure C × 3, figures A, D, F, G, I, J $\times 6$, and figures B, E, $\mathrm{H} \times 10$. Scale bars equal $1 \mathrm{~mm}$. 
Petr Štorch et al. • Uppermost Ordovician graptolites of north-central Nevada
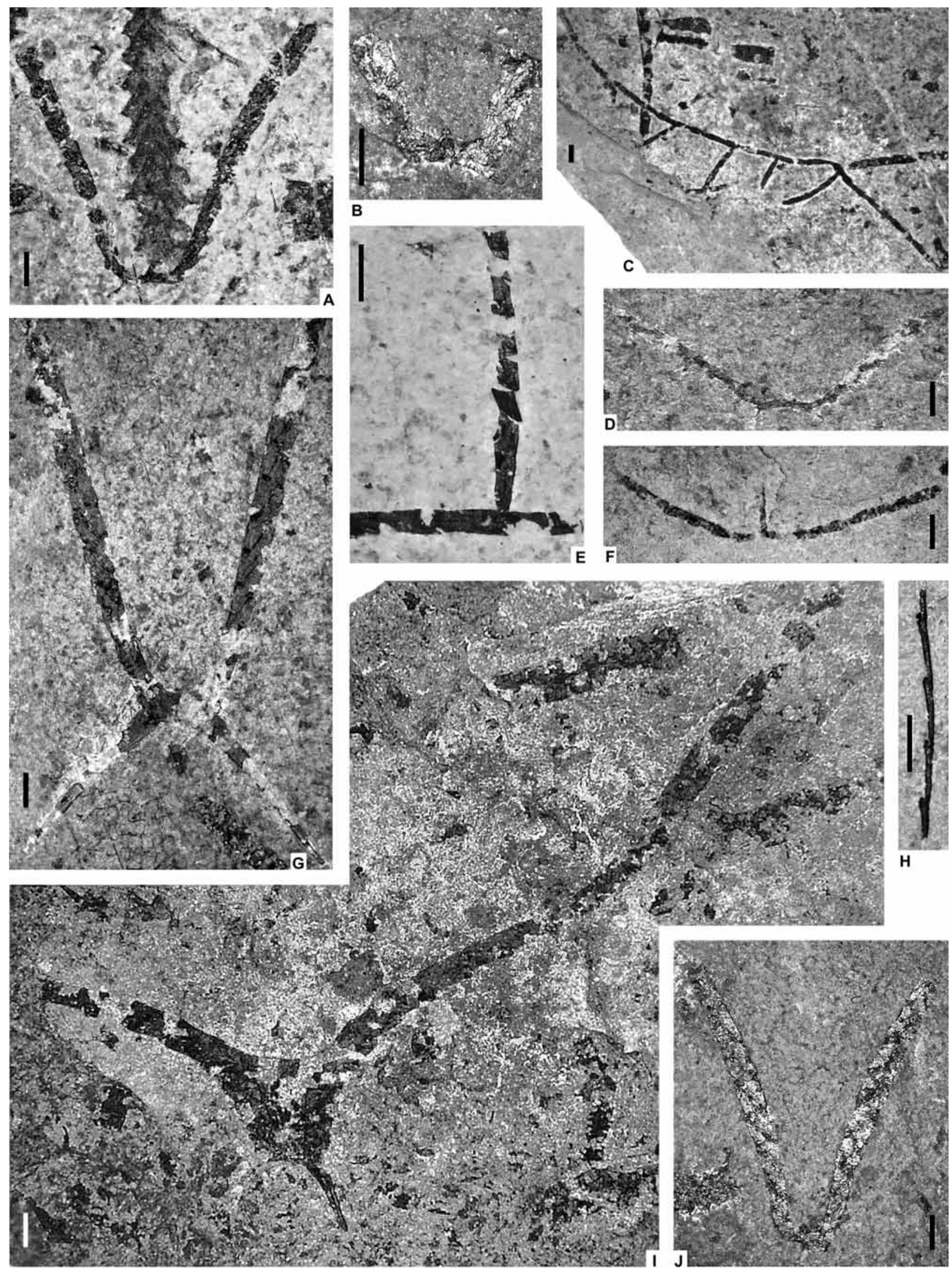
Remarks. - Immature rhabdosomes, when complete, can be easily differentiated from Dicellograptus minor Toghill by their open, dish-like profile without an abrupt bend above the first thecal pair (Fig. 8L, M), which is accentuated by the conspicuous subapertural basal spines in $D$. $m i$ nor. In contrast to the majority of dicellograptids, a prominent longiconic sicula is commonly preserved in young rhabdosomes of Pleurograptus lui, but the sicular apex was resorbed in mature rhabdosomes of $\mathrm{Pl}$. lui. Such specimens are further distinguishable, however, by having one or more secondary stipes on each of the two primary stipes. In comparison to Pleurograptus linearis (Carruthers), rhabdosomes of $P l$. lui are marked by a particularly slender procladium and metacladia and a lesser number of metacladia.

Superfamily Diplograptoidea Lapworth, 1880, emend. Mitchell et al., 2007b

Remarks. - Some of morphological characters measured and used in systematic descriptions of diplograptoid rhabdosomes are depicted in Fig. 13.

Family Diplograptidae Lapworth, 1873, emend. Mitchell et al., 2007b

\section{Genus Diplograptus Mc Coy, 1850 , emend. Mitchell et al., 2009}

Type species. - Prionotis pristis Hisinger, 1837, p. 114, pl. 35, fig. 5; designated by Gurley 1896, p. 78.

\section{Diplograptus rarithecatus (Ross \& Berry, 1963)}

Figures 14H, P-R, 15J, N-P, Table 5

1963 Orthograptus truncatus var. rarithecatus n. var.; Ross \& Berry, pp. 150, 151, pl. 12, figs 11-15.

1963 Orthograptus truncatus var. richmondensis (Ruedemann 1947). - Ross \& Berry, p. 151, pl. 12, figs $23-25$.
1993 Orthograptus rarithecatus Ross \& Berry. - Mu et al., p. 192, pl. 42, figs 4-10.

2009 Diplograptus rarithecatus (Ross \& Berry, 1963). Mitchell et al., fig. 2J, K.

Material and stratigraphical range. - 18 flattened specimens of this uncommon species originate from black shales and lime-mudstones of the ornatus and pacificus biozones of the Vinini Creek and Monitor Range sections. Ten rhabdosomes have been measured in detail.

Description. - Robust septate diplograptid with rhabdosome $>50 \mathrm{~mm}$ in length, and $2.8 \mathrm{~mm}$ maximum distal width. Sicula $>2 \mathrm{~mm}$ long; aperture $0.2-0.3 \mathrm{~mm}$ wide, lacks antivirgellar spines but with prominent virgella. Th1 ${ }^{1}$ extends $0.15-0.25 \mathrm{~mm}$ below the sicular aperture before it turns upwards and outwards. Ventrally directed th $1^{2}$ crosses the sicula $0.2-0.3 \mathrm{~mm}$ above sicular aperture. First thecal pair with prominent ventrally directed subapertural spines and metathecae inclined at more than $45^{\circ}$ to the rhabdosome axis; resulting proximal profile unusually broad and markedly asymmetric. Rhabdosome widens gradually from $1.05-1.3 \mathrm{~mm}$ at the first thecal pair to $1.2-1.45 \mathrm{~mm}$ at th3, $1.45-1.6 \mathrm{~mm}$ at th $5,1.8-2.15 \mathrm{~mm}$ at th 10 and continues to widen over entire recorded length. Thecae long tubes with large apertures, slight pseudogenicula and short (0.3-0.5 mm) supragenicular walls. Thecal apertures concave, slightly introverted or perpendicular to the rhabdosome axis. Rock compaction commonly enhances pseudogenicula producing markedly geniculate appearance. Despite this deformation, however, thecae generally become almost straight distally. Thecae overlap $<1 / 2$ length proximally and $\sim 1 / 2$ distally. 2TRD increases from $1.15-1.35 \mathrm{~mm}$ at th2 to $1.6-1.9 \mathrm{~mm}$ at th5 and $2-2.25 \mathrm{~mm}$ at th10. Distal thecae number 9-7 in $10 \mathrm{~mm}$ (2TRD: $2.15-2.9 \mathrm{~mm}$ ).

Remarks. - Robust diplograptid rhabdosomes from late Katian Vinini Formation have been assigned to Diplograptus rarithecatus by Mitchell et al. (2009). Type specimens of D. rarithecatus, from the Phi Kappa Formation slates of Idaho (USGS collection D1368), however, are considerably

Figure 12. A, B, G-J, P-R - Rectograptus abbreviatus (Elles \& Wood, 1907): A - USNM 542671, level 7.75 m; B - USNM 542680, level 7.50 m; G - USNM 542676, level $17.60 \mathrm{~m}$; H - USNM 542725b, level $7.65 \mathrm{~m}$; I - USNM 542731, level $9.80 \mathrm{~m}$; J - USNM 542696, level 10.80 m; P - USNM 542707, level 11.70 m; Q - USNM 542745a, level MR 90.20 m; R - USNM 542743, level MR 95.00 m. • D-F - Paraorthograptus uniformis Mu \& Li, 1984: D - USNM 542806, level 27.85 m; E - USNM 542774, level MR 105.2 m; F - USNM 542776, level 105.2 m. • C, K, N, S - Paraorthograptus pacificus (Ruedemann, 1947): C - USNM 542791, level 10.30 m; K - USNM 542710, level 11.70 m; N - USNM 542697, level 10.80 m; S - USNM 542860, level $10.30 \mathrm{~m} \cdot \bullet \mathrm{L}$ - Dicellograptus tumidus Chen, 1978: USNM 542673, level $9.20 \mathrm{~m} . \bullet \mathrm{M}$ - Dicellograptus cf. anceps (Nicholson, 1867): USNM 542683, level $7.75 \mathrm{~m}$. O - Dicellograptus turgidus Mu, 1963: USNM 542859, level $10.30 \mathrm{~m}$. $・$ T - Diceratograptus mirus Mu, 1963: USNM 542789, level $18.00 \mathrm{~m}$. $\cdot$ USNM 542671, 542680, 542683, 542725, 542743 and 542745a from the ornatus Biozone, USNM 542673, 542676, 542696, $542697,542707,542710,542731,542774,542776,542789,542791,542859$ and 542860 from the pacificus Biozone and USNM 542806 from the persculptus Biozone. USNM 542671, 542673, 542676, 542680, 542683, 542696, 542697, 542707, 542710, 542725, 542731, 542789, 542791, 542806, 542859 and 542860 from the Vinini Creek section, USNM 542743, 542745a, 542774 and 542776 from the Martin Ridge section. All figures $\times 6$ (common scale bar equals $1 \mathrm{~mm}$ ), except $\mathrm{A}, \mathrm{T} \times 10$ (assigned scale bar equals $1 \mathrm{~mm}$ ). 
Petr Štorch et al. • Uppermost Ordovician graptolites of north-central Nevada
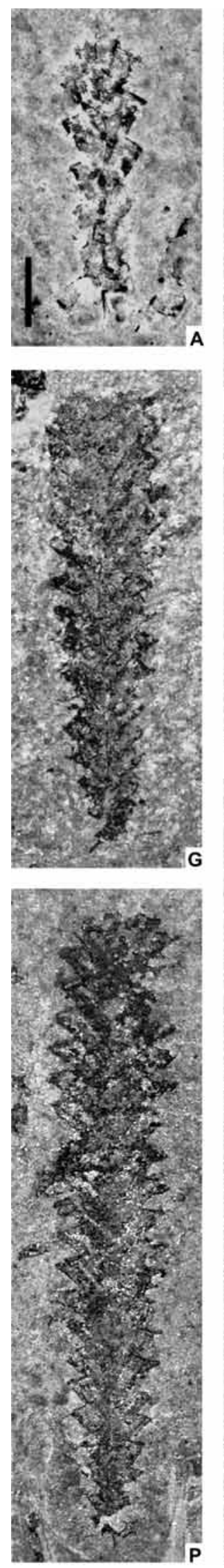
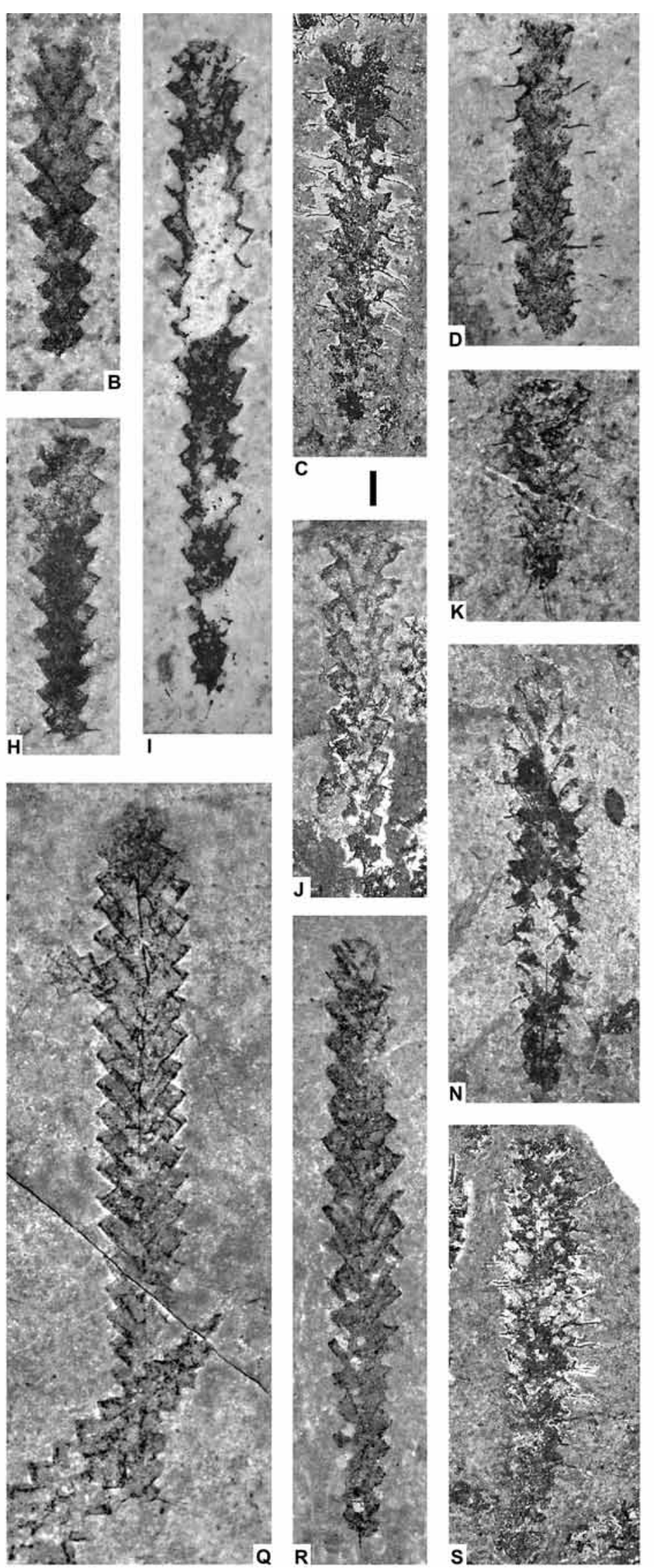
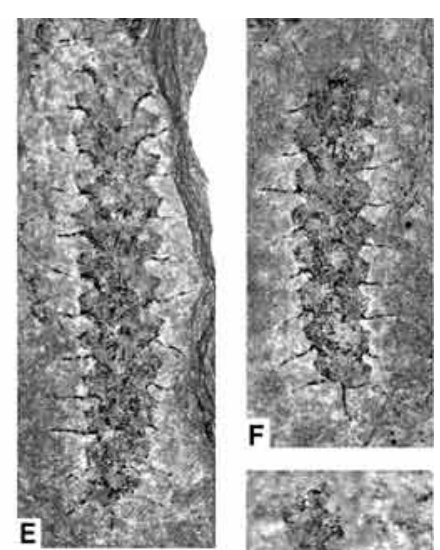

argations
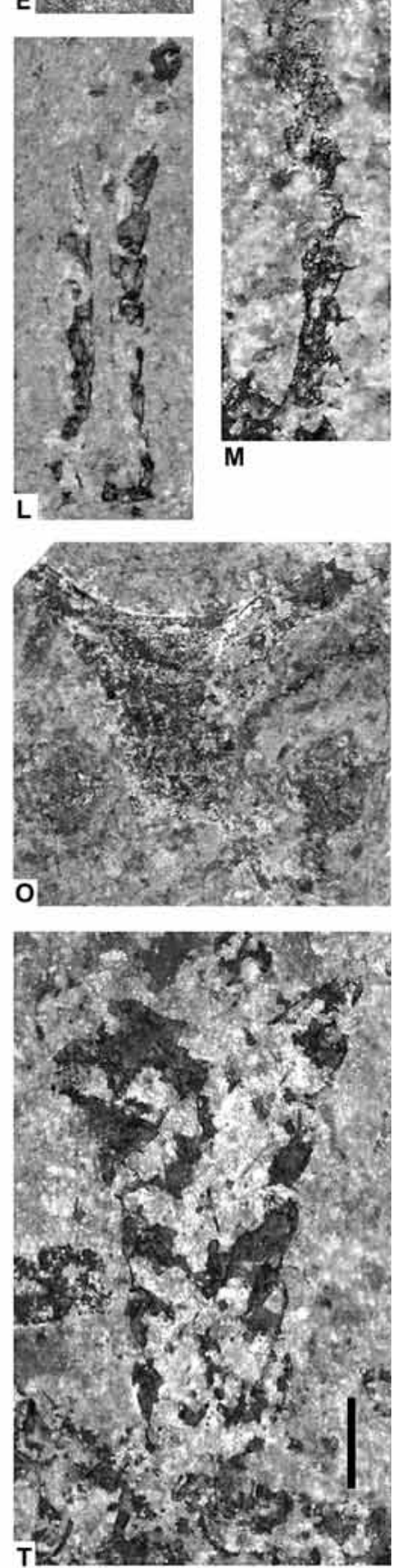
Table 5. Diplograptus rarithecatus. Dimensions of illustrated and other exemplary specimens (in $\mathrm{mm}$ ).

\begin{tabular}{|c|c|c|c|c|c|c|c|c|c|}
\hline \multirow{2}{*}{ Specimen USNM } & \multirow{2}{*}{ Text-figure } & \multicolumn{4}{|c|}{ W } & \multicolumn{4}{|c|}{ 2TRD } \\
\hline & & th1 & th5 & th10 & dist. & th2 & th5 & th10 & dist. \\
\hline 542798 & $14 \mathrm{H}, 15 \mathrm{P}$ & 1.3 & 1.6 & $?$ & 2.4 & 1,35 & 1.85 & $?$ & 2.9 \\
\hline 542773 & $14 \mathrm{P}, 15 \mathrm{~N}$ & 1.2 & 1.45 & 2.15 & 2.4 & 1,35 & 1.75 & 2.15 & - \\
\hline 542748 & $14 Q, 15 O$ & 1.25 & 1.5 & 1.8 & 2.8 & 1.15 & 1.75 & 2.25 & 2.4 \\
\hline 542857 & $14 \mathrm{R}, 15 \mathrm{~J}$ & 1.05 & 1.45 & 1.95 & - & 1.3 & 1.852 & 2.0 & - \\
\hline 542772 & - & $?$ & 1.45 & 2.0 & 2.8 & 1.2 & 1.75 & 2.1 & 2.15 \\
\hline
\end{tabular}

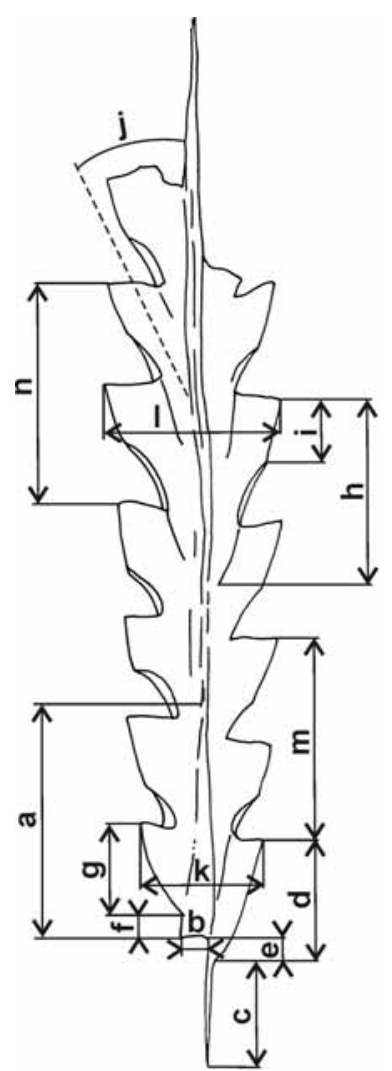

Figure 13. Some of the characters measured on diplograptoid rhabdosomes in this study: a - apparent length of the sicula, $b$ - width of the sicular aperture, $\mathrm{c}-$ length of the virgella, $\mathrm{d}-$ length of the upward growing portion of th $1^{1}$, e - distance between sicular aperture and turning point of th $1^{1}, \mathrm{f}-$ length of exposed part of the sicula, $\mathrm{g}-$ length of th $1^{2}, \mathrm{~h}-$ length of the post-proximal theca, $i$ - length of the supragenicular wall, $\mathrm{j}$ - thecal inclination, $\mathrm{k}$ - rhabdosome width at the first thecal pair, $1-$ rhabdosome width at th5, $\mathrm{m}-2 \mathrm{TRD}_{2}, \mathrm{n}-$ $2 \mathrm{TRD}_{5}$.

broadened by flattening combined with tectonic deformation. This collection also includes material referred by Ross \& Berry (1963) to Orthograptus truncatus richmondensis, which appears to belong to this taxon as well. Mitchell et al. (2009) also noted remarkable similarity of D. rarithecatus to "Glyptograptus" teretiusculus occidentalis Ruedemann (1947). The only figured rhabdosome, the holotype, of the latter species comes from the same Phi Kappa Formation collection as D. rarithecatus (USGS D1368). It is strongly stretched obliquely to its longitudinal axis so that its thecae appear less overlapping and more smoothly geniculate than in the specimens of $D$. rarithecatus, which are oriented more nearly orthogonal to the principle elongation. The identity of the two species is uncertain given the degree of deformation the specimens have undergone and so we prefer to use the name associated with the more well-preserved material. Diplograptus maximus
(Mu, 1945) can be distinguished from $D$. rarithecatus by its widely spaced thecae relative to the rhabdosome width both proximally and in its mesial part.

\section{Diplograptus rigidus (Lee in Wang, 1974) Figure 15I}

1974 Orthograptus rigidus; Lee (in Wang), p. 746, pl. 29, fig. 10.

1988 Orthograptus rigidus Lee. - Li \& Cheng, pp. 168, 169, pl. 1, fig. 7; text-fig. 2a, b.

1993 Orthograptus rigidus Lee. - Mu et al., pp. 191, 192, pl. 42, figs $1-3$.

1993 Orthograptus augescens $\mathrm{Li}$ (sp. nov.). - Li in $\mathrm{Mu}$ et al., pp. 193, 194, 347, pl. 43, figs 5, 6, 9, 14, 15.

1993 Orthograptus yangtziensis $\mathrm{Li}$ (sp. nov.). - Li in $\mathrm{Mu}$ et al., pp. 194, 347, 348, pl. 43, figs 8, 10, 11, 16.

2009 Diplograptus rigidus (Lee). - Mitchell et al., fig. 2I.

Material and stratigraphical range. - Three rhabdosomes from the pacificus Subzone of Vinini Creek section have been assigned to this species. Illustrated specimen originated from black shale at $11.70 \mathrm{~m}$.

Description. - Rhabdosome robust, $1.4-1.5 \mathrm{~mm}$ wide across first thecal pair, widening to $1.55-1.8 \mathrm{~mm}$ at th 3 , and $1.8-2.25 \mathrm{~mm}$ at th5. Longest of three specimens available $2.4 \mathrm{~mm}$ wide at th10. Sicula largely hidden by th $1^{2}$, aperture $0.3 \mathrm{~mm}$ wide, lacks antivirgellar spines but possesses short and robust virgella. Early astogeny of $D$. pristis type. First thecal pair with prominent ventrally directed subapertural spines and metathecae strongly outwardly inclined ( $\sim 60^{\circ}$ from the rhabdosome axis); resulting proximal profile very broad and subsymmetric. Apart from weak pseudogenicula enhanced by rock compaction, tubular thecae almost straight, inclined at $40-45^{\circ}$ to the rhabdosome, with short supragenicular wall. Thecae overlap for at least half their length. Apertural margin straight, perpendicular to thecal axis or slightly introverted. Apertures deep and open but with strongly concave supra-apertural wall. The 2TRD $1.3-1.5 \mathrm{~mm}$ at th2, $1.6-1.85 \mathrm{~mm}$ at th5 and $1.9-2.1 \mathrm{~mm}$ at th10. 
Remarks. - Diplograptus rigidus (Lee, 1974) can be readily distinguished from other late Katian diplograptids by its particularly wide proximal end. Thecae of the first pair are highly inclined outwards, which gives the proximal part a typically blunt outline. The relatively dense thecal spacing and high angle of inclination produces a disproportionately wide rhabdosome. All of these characters, along with other rhabdosome and thecae parameters are present in Orthograptus augescens Li, 1993 and Orthograptus yangtziensis $\mathrm{Li}, 1993$, which we consider junior synonyms of $D$. rigidus (Lee, 1974), as already suggested by Mitchell et al. (2009).

\section{Genus Rectograptus Přibyl, 1949}

Type species. - Diplograptus pristis var. truncatus Lapworth, 1877; p. 133, pl. 6, fig. 17; designated by Přibyl, 1949, p. 25.

Rectograptus abbreviatus (Elles \& Wood, 1907) Figures 12A, B, G-J, P-R, 16J-L, R-U, Table 6

1907 Diplograptus (Orthograptus) truncatus var. abbreviatus; Elles \& Wood, p. 235, pl. 29, fig. 6a-e.

1945 Retiolites tsunyiensis; Mu, p. 206, pl. 1, fig. 5a, b.

1963 Orthograptus truncatus var. abbreviatus Elles \& Wood. - Ross \& Berry, p. 149, pl. 11, fig. 26; pl. 12, fig. 6 .

1970 Orthograptus truncatus abbreviatus Elles \& Wood. Toghill, p. 24, pl. 15, figs 4-6; pl. 16, figs 6a-e.

non 1974 Orthograptus truncatus abbreviatus Elles \& Wood, 1907. - Hutt, p. 33, pl. 8, figs 9, 10; text-fig. 8, fig. 9.

1980 Orthograptus amplexicaulis amplexicaulis (J. Hall, 1847). - Koren' et al. (in Apollonov et al.), pp. 156, 157, pl. 49, figs 5-8; pl. 50, fig. 1; text-fig. 49a, б.

1982 Orthograptus? abbreviatus Elles \& Wood. - Williams, p. 41, pl. 4, figs 7-12.

1983 Orthograptus amplexicaulis abbreviatus Elles \& Wood, 1907. - Koren' \& Sobolevskaya (in Koren' et al.), pp. 149, 150, pl. 44, figs 5-7; text-fig. 56a-3.

?1983 Orthograptus amplexicaulis strigosus Ross \& Berry, 1963. - Koren' \& Sobolevskaya (in Koren' et al.), pp. 150-152, pl. 44, figs 8-13; text-fig 57a-1.

1993 Orthograptus tsunyiensis $\mathrm{Mu}$. - Li (in $\mathrm{Mu}$ et al.), p. 194, pl. 41, figs 5,6 .

1993 Rectograptus abbreviatus (Elles \& Wood). - Li (in Mu et al.), p. 201, pl. 43, fig. 17; pl. 44, figs 10, 12, 13; pl. 45, figs 1-6, 14, 15.

1993 Rectograptus abbreviatus huloensis; Li (in Mu et al.), p. 202, pl. 46, figs 15,16 .

1993 Rectograptus ensiformis; Li (in Mu et al.), p. 199, pl. 44, figs 8, 9; text-fig. 27c.

1993 Rectograptus carnei (T.S. Hall). - Li (in Mu et al.), p. 200, pl. 44, fig. 11.
1993 Rectograptus gracilis sinicus; Li (in $\mathrm{Mu}$ et al.), p. 205, pl. 46, figs 6, 17, 18; text-fig. 28b.

2002 Orthograptus amplexicaulis abbreviatus Elles \& Wood, 1907. - Rickards, pp. 11, 12, figs 8B-F, ?K, L.

2002 Rectograptus abbreviatus (Elles \& Wood). - Mu et al., pp. 710, 711, pl. 195, fig. 1.

2005a Rectograptus abbreviatus (Elles \& Wood, 1907). Chen et al., pp. 241, 242, text-fig. 3T.

Material and stratigraphical range. - Common species ranging from the ornatus Biozone to the pacificus Biozone in the Vinini Creek and Monitor Range sections. More than 50 flattened specimens (41 measured) have been preserved in varied limestones, lime mudstones, mudstones and black shales.

Description. - Aseptate rhabdosome may exceed $26 \mathrm{~mm}$ maximum length and rhabdosome width varies substantially; widens from $0.75-1.1 \mathrm{~mm}$ at asymmetrical first thecal pair to a maximum of $2.0-3.3 \mathrm{~mm}$, attained between $11^{\text {th }}-23^{\text {rd }}$ thecal pair (see Table 6 for details). Most distally the rhabdosome width commonly decreases giving sub-fusiform appearance to the mature specimens. Flattening patterns correspond to tabulate-rectangular cross section of the rhabdosome. Sicula $1.5-1.7 \mathrm{~mm}$ long and $0.2-0.3 \mathrm{~mm}$ wide at the aperture, furnished with tiny virgella and two proximo-ventrally directed antivirgellar spines, although only one antivirgellar spine visible in most cases. Th $1^{1}$ extends down along the sicula before turning upwards and outwards. Distinct mesial spine developed well below th $1^{1}$ aperture. Outward growing th $1^{2}$ crosses sicula at sicular aperture. Following few thecal pairs commonly show rounded geniculum and more distal thecae long, straight with long interthecal septa; apertures simple, slightly to moderately everted. Thecae $0.75-1.1 \mathrm{~mm}$ long at th3, 1.35-1.75 $\mathrm{mm}$ long at th 10 , and inclined at $32^{\circ}-50^{\circ}$ to rhabdosome axis. Distal thecae commonly $>2 \mathrm{~mm}$ long, overlap for half to three-fifths of their length. $2 \mathrm{TRD}_{2}$ : 1.1-1.45 mm, 2TRD $5: 1.3-1.75 \mathrm{~mm}$. Distal thecae number 10-14 in $10 \mathrm{~mm}$ (2TRD: $1.4-1.95 \mathrm{~mm}$ ).

Remarks. - This is a cosmopolitan species that exhibits a considerable variability within bedding plane assemblages in our sections. Thecal overlap varies greatly along with thecal length. Rhabdosomes with lesser thecal inclination and, as a rule, shorter thecae are narrower than those with longer, more inclined and thus, more overlapping thecae. We do not consider this variation to be taxonomically significant. $R$. abbreviatus, despite this variability, is nonetheless smaller and narrower than Rectograptus uniformis (Mu \& Li in Wang et al. 1978). The latter species is up to $4.2 \mathrm{~mm}$ wide according to Chen et al. (2005a) and its thecae are more widely spaced $\left(2 \mathrm{TRD}_{5}\right.$ is $1.85 \mathrm{~mm}$ and $2 \mathrm{TRD}_{\text {dist }}$ reaches $2.23 \mathrm{~mm}$ ). 
Table 6. Rectograptus abbreviatus. Dimensions of illustrated specimens (in mm) and thecal inclination (in ${ }^{\circ}$ ).

\begin{tabular}{|c|c|c|c|c|c|c|c|c|c|c|}
\hline \multirow{2}{*}{ Specimen USNM } & \multirow{2}{*}{ Text-figure } & \multicolumn{4}{|c|}{ W } & \multirow{2}{*}{ Dist. thecal incl. } & \multirow{2}{*}{ Dist. thecal L } & \multicolumn{3}{|c|}{ 2TRD } \\
\hline & & th1 & th3 & th10 & dist. max & & & th2 & th5 & dist. \\
\hline 542743 & $12 \mathrm{R}, 16 \mathrm{~J}$ & 0.85 & 1.25 & 1.75 & 1.95 & $33^{\circ}$ & 1.5 & 1.2 & 1.45 & 1.6 \\
\hline 542731 & $12 \mathrm{I}, 16 \mathrm{~K}$ & 0.9 & 1.3 & 1.7 & 2.1 & $32-35^{\circ}$ & 1.6 & 1.2 & 1.45 & 1.6 \\
\hline $542725 a$ & $16 \mathrm{~L}$ & 0.75 & $?$ & 2.05 & 2.15 & $37^{\circ}$ & 1.7 & 1.25 & 1.7 & 1.7 \\
\hline 542707 & $12 \mathrm{P}, 16 \mathrm{R}$ & 1.05 & 1.95 & 2.6 & 3.3 & $43^{\circ}$ & 1.8 & 1.15 & 1.3 & 1.5 \\
\hline $542745 a$ & $12 \mathrm{Q}, 16 \mathrm{~S}$ & 0.75 & $?$ & 1.75 & 2.25 & $40^{\circ}$ & 1.6 & 1.2 & $?$ & 1.4 \\
\hline $542745 b$ & $16 \mathrm{~T}$ & 0.8 & $?$ & 2.2 & - & $34^{\circ}$ & 1.7 & 1.2 & 1.5 & 1.7 \\
\hline 542676 & $12 \mathrm{G}, 16 \mathrm{U}$ & $?$ & 1.85 & 2.45 & - & $48^{\circ}$ & $>1.7$ & 1.25 & 1.35 & 1.5 \\
\hline 542671 & $12 \mathrm{~A}$ & 0.72 & 1.1 & - & - & $37^{\circ}$ & - & 1.2 & 1.35 & - \\
\hline 542680 & $12 \mathrm{~B}$ & 0.92 & 1.3 & - & - & $44^{\circ}$ & - & 1.2 & 1.7 & - \\
\hline $542725 \mathrm{~b}$ & $12 \mathrm{H}$ & 0.95 & 1.25 & $\sim 1.85$ & - & $40-45^{\circ}$ & - & 1.3 & 1.5 & - \\
\hline
\end{tabular}

\section{Genus Paraorthograptus Mu et al., 1974}

Type species. - Climacograptus innotatus var. pacificus, Ruedemann, p. 429, pl. 73, fig. 20; subsequently designated by Williams (1982).

\section{Paraorthograptus pacificus (Ruedemann, 1947)}

Figures 12C, K, N, S, 16M, N

1947 Climacograptus innotatus var. pacificus; Ruedemann, p. 429, pl. 73, fig. 20.

1963 Climacograptus innotatus var. pacificus Ruedemann. - Ross \& Berry, p. 125, pl. 8, fig. 21.

1974 Climacograptus pacificus Ruedemann. - Riva, p. 1457, fig. 2a-h.

1974 Climacograptus pacificus pilosus; Riva, p. 1459, fig. 2a.

1974 Paraorthograptus typicus; Mu (in Nanjing Institute of Geology and Palaeontology ed.), p. 161, pl. 70, fig. 15.

1979 Pacificograptus pacificus pacificus (Ruedemann). Koren', p. 71, text-fig. 1a-c.

1980 Pacificograptus pacificus pacificus (Ruedemann). Koren' (in Apollonov et al., 1980), pp. 126-128, pl. 34, figs 6-10; text-fig. 32a-i.
1980 Pacificograptus pacificus affinis subsp. n.; Koren' \& Tzai (in Apollonov et al.), pp. 128, 129, pl. 35, figs 1-6; text-fig. 32k-n.

1982 Paraorthograptus brevispinus; $\mathrm{Mu} \& \mathrm{Li}$ (in Fu et al.), pp. 467, pl. 292, fig. 6.

1982 Paraorthograptus pacificus (Ruedemann, 1947). Williams, p. 42, text-fig. 10d-i.

1987 Paraorthograptus pacificus (Ruedemann, 1947). Melchin, p. 200, pl. 2, figs 15-17.

1993 Paraorthograptus pacificus (Ruedemann). - Mu \& Li (in Mu et al.), p. 211, pl. 48, figs 5, 20; pl. 49, figs 1, 2.

1993 Paraorthograptus typicus $\mathrm{Mu}$ - Mu \& Li (in Mu et al.), pp. 208, 209, pl. 48, figs 1-4, 6-9, 11-12; pl. 50, fig. 16; text-fig. 29a.

1993 Paraorthograptus angustus; $\mathrm{Mu} \& \mathrm{Li}$ (in $\mathrm{Mu}$ et al.), p. 210, pl. 48, figs 13-19; pl. 49, fig. 3; pl. 50, fig. 13.

2002 Paraorthograptus pacificus (Ruedemann). - Mu et al., p. 734, pl. 200, fig. 14.

2005a Paraorthograptus pacificus (Ruedemann, 1947); Chen et al., pp. 243, 244, text-fig. 3D, J, M, N, W.

2005a Paraorthograptus brevispinus $\mathrm{Mu} \& \mathrm{Li}$. - Chen et al., p. 244, text-fig. 3F, I, L, Q-S.

Material and stratigraphical range. - Index species that is common in the pacificus Zone in Vinini Creek and Monitor

Figure 14. A, C - Anticostia fastigata (Davies, 1929): A - USNM 542677, level $7.50 \mathrm{~m}$; C - USNM 542811, level $17.80 \mathrm{~m} . \bullet \mathrm{B}, \mathrm{I}-\mathrm{K}, \mathrm{S}, \mathrm{T}-P a-$ rareteograptus sinensis Mu, 1974: B - USNM 542684, level 7.65 m; I - USNM 542771, level MR 105.2 m; J - USNM 542763, level MR 96.13 m; K - USNM 542687, level 7.75 m; S - USNM 542746, level MR $112.8 \mathrm{~m} ; \mathrm{T}$ - USNM 542858, level MR $105.2 \mathrm{~m}$. $\mathrm{D}$ - Anticostia thornsteinssoni Melchin, 1987: USNM 542669, level 1.55 m. • E, F, M - Anticostia uniformis (Mu \& Lin, 1993): E - USNM 542812, level 17.80 m; F - USNM 542716, level $18.30 \mathrm{~m}$; M - USNM 542672, level $16.00 \mathrm{~m}$. $\mathrm{G}$, O, Y - Anticostia lata (Elles \& Wood, 1906): G - USNM 542681, level 14.15 m; O - USNM 542850, level $14.15 \mathrm{~m}$; Y - USNM 542849, level $14.15 \mathrm{~m} . \bullet \mathrm{H}, \mathrm{P}-\mathrm{R}$ - Diplograptus rarithecatus (Ross \& Berry, 1963): H - USNM 542798, level $10.30 \mathrm{~m}$; P - USNM 542773, level MR $105.2 \mathrm{~m}$; Q - USNM 542748, level MR $112.8 \mathrm{~m}$; R - USNM 542857, level MR $105.2 \mathrm{~m}$. $・ \mathrm{~L}$ - Anticostia macgregorae Stewart \& Mitchell, 1997: USNM 542720, scree. • N, U-X - Anticostia tenuissima (Ross \& Berry, 1963): N - USNM 542761, level MR $96.13 \mathrm{~m}$; U - USNM 542757, level MR $96.13 \mathrm{~m}$; V - USNM 542755a, W - 542755b, level MR 96,13 m; X - USNM 542688, level 7.75 m. • USNM $542669,542677,542684,542687,542688,542755 \mathrm{a}, \mathrm{b}, 542757,542761$ and 542763 from the ornatus Biozone and USNM 542672, 542681, 542716, $542720,542746,542748,542771,542773,542798,542811,542812,542849,542850,542857$ and 542858 from the pacificus Biozone. A-H, K-M, O, Y from the Vinini Creek section, I, J, N, P-X from the Martin Ridge section. All figures $\times 6$. Scale bar equals $1 \mathrm{~mm}$. 
Petr Štorch et al. • Uppermost Ordovician graptolites of north-central Nevada

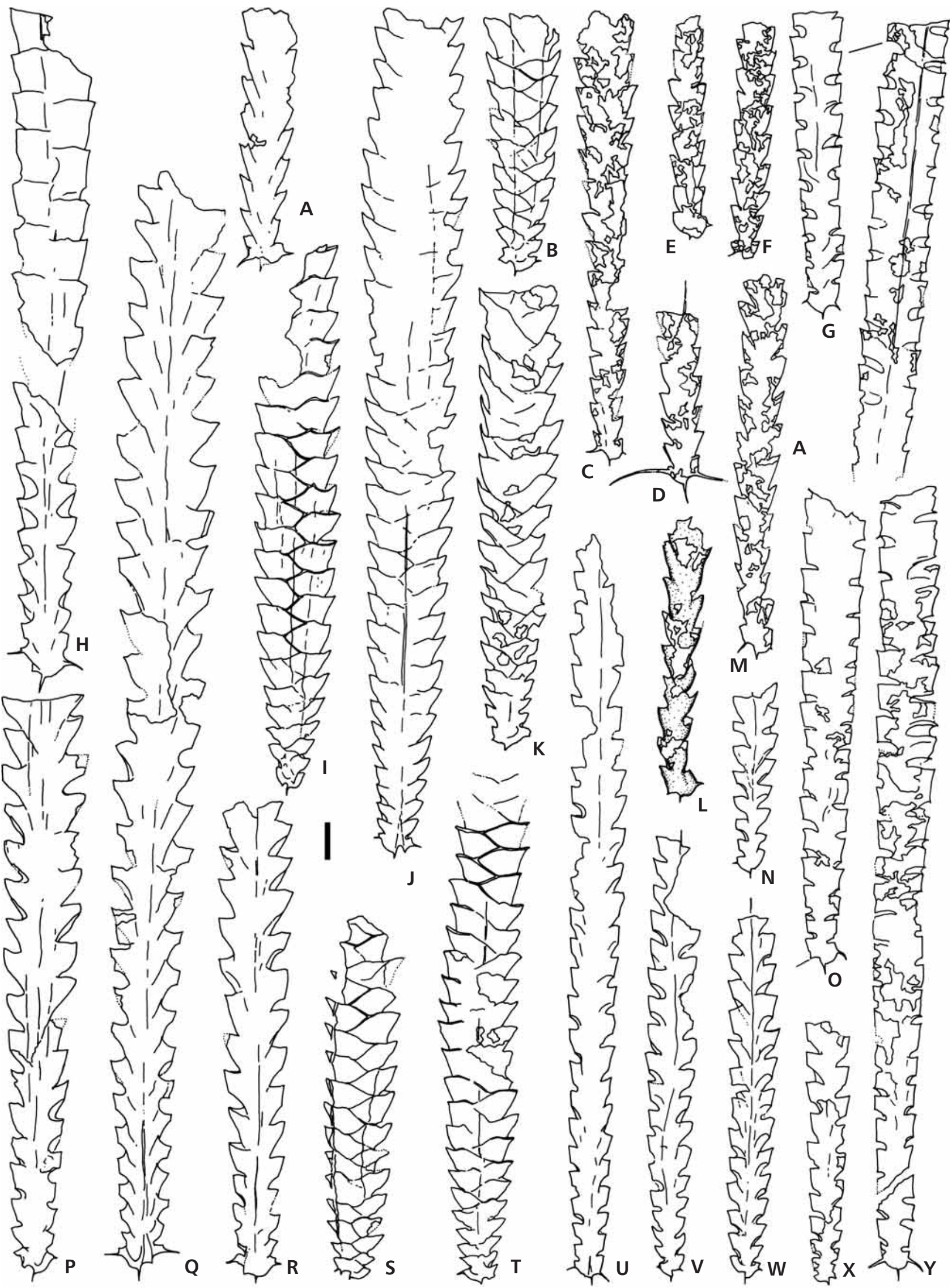


Table 7. Paraorthograptus uniformis. Dimensions of illustrated specimens (in $\mathrm{mm}$ ).

\begin{tabular}{llllllllc}
\hline \multirow{2}{*}{ Specimen USNM } & Text-figure & \multicolumn{3}{c}{ W } & \multicolumn{3}{c}{2 TRD } \\
\cline { 3 - 9 } & & th1 & th3 & th5 & dist. max & th2 & th5 & dist. th \\
\hline 542806 & $12 \mathrm{D}, 16 \mathrm{D}$ & $?$ & $?$ & 1.5 & 1.5 & $?$ & 1.5 & 1.5 \\
542776 & $12 \mathrm{~F}, 16 \mathrm{G}$ & 0.9 & 1.05 & 1.2 & 1.35 & 1.15 & 1.2 & 1.25 \\
542774 & $12 \mathrm{E}, 16 \mathrm{H}$ & 0.9 & 1.1 & 1.25 & 1.25 & 1.05 & 1.2 & 1.2 \\
\hline
\end{tabular}

Range; rare finds continued through extraordinarius to persculptus Zone in the Vinini Creek section. 13 of more than 30 flattened, mostly incomplete specimens, preserved in lime mudstones, mudstones and black shales, have been measured in detail.

Description. - Rhabdosome aseptate, widening from $0.75-0.9 \mathrm{~mm}$ at th1, $0.9-1.2 \mathrm{~mm}$ at th3, to $1.2-1.4 \mathrm{~mm}$ at th5. Maximum width $1.35-2.0 \mathrm{~mm}$ by th10-th12. Longest specimen (which is nonetheless incomplete): $24 \mathrm{~mm}$. Sicula $\sim 1.5 \mathrm{~mm}$ long, aperture $0.2-0.3 \mathrm{~mm}$ wide, bearing virgella and paired antivirgellar spines. Th $1^{1}$ with mesial spine. Thecae strongly geniculate, with almost semicircular, 0.25-0.45 mm wide, apertural excavations. Supragenicular walls short $(0.3-0.5 \mathrm{~mm})$, slightly outwardly inclined. Genicula possess robust, paired, $0.3-1.2 \mathrm{~mm}$ long spines. Spine length variable and strongly influenced by taphonomy. 2TRD $0.9-1.15 \mathrm{~mm}$ at th2; $1.15-1.3 \mathrm{~mm}$ at th5. Distal thecae number $10.5-15$ in $10 \mathrm{~mm}$ (2TRD $1.25-1.9 \mathrm{~mm})$.

Remarks. - The species is highly variable and the form presented is strongly influenced by preservational effects. Thin-walled aseptate rhabdosome seems to be easily flattened and variously broadened in clayey and muddy sediments. Spines are often broken or buried in the sediment and seldom preserved in their full length. Thus, the paired arrangement of thecal and antivirgellar spines is rarely evident. Several species that have been recognized largely upon differences in width of their rhabdosomes and length of genicular spines (Climacograptus pacificus pilosus Riva, Pacificograptus pacificus affinis Koren' \& Tzai, $P a-$ raorthograptus typicus $\mathrm{Mu}$ and Paraorthograptus angustus $\mathrm{Mu} \& \mathrm{Li}$ ) are junior synonyms of Po. pacificus. With regard to considerable preservational variability of thecal spines we also suggest that Paraorthograptus brevispinus $\mathrm{Mu} \& \mathrm{Li}$ should be included in the long synonymy list of Po. pacificus.

Paraorthograptus uniformis Mu \& Li in Mu \& Lin, 1984 Figures 12D-F, 16D, G, H, Table 7

1983 Paraorthograptus uniformis Mu (MS); Wang (in Wang et al.), pl. 6, fig. 5.

1984 Paraorthograptus uniformis; Mu \& Li (in Mu \& Lin), p. 62 , pl. 4, fig. 1 ; pl. 6 , figs 7,8 .

1993 Paraorthograptus uniformis Mu \& Li. - Mu \& Li (in Mu et al.), pp. 211, 212, pl. 49, figs 15-20; pl. 50, figs 1,2 , text-fig. 29b.

2005a Paraorthograptus uniformis Mu \& Li, 1984. - Chen et al., pp. 244, 245, text-fig. 3U, V, X, Y.

Material and stratigraphical range. - 11 flattened, moderately well preserved specimens from a lime-mudstone bed within the pacificus Zone at $105.2 \mathrm{~m}$ in the Monitor Range Section.

Description. - Small rhabdosome up to $\sim 15 \mathrm{~mm}$ long and characterized by rather uniform width. Proximal end blunt, 0.8-1.2 mm wide at th1, furnished with four basal spines: virgella, two antivirgellar spines (of which only one commonly visible) and mesial spine on th $1^{1}$. Maximum width of the rhabdosome $1.2-1.7 \mathrm{~mm}$ by 5 th thecal pair, or little higher. Strongly geniculate thecae with prominent, 0.5-0.7 $\mathrm{mm}$ long spines, apertural excavations $0.25-0.33 \mathrm{~mm}$ wide, slightly everted, and with short $(\sim 0.3 \mathrm{~mm})$, outwardly inclined supragenicular walls. Thecae overlap one-third their length. 2TRD: 0.95-1.15 mm at th2; $1.2-1.45 \mathrm{~mm}$ distally.

Figure 15. A, E, F, H, K-M - Parareteograptus sinensis Mu, 1974: A - USNM 542856, level MR 105.2 m; E - USNM 542714, level 3.30 m; F - USNM 542684, level 7.65 m; H - USNM 542845, level 7.75 m; K - USNM 542763, level MR 96.13 m; L - USNM 542771, level MR 105.2 m; M - USNM 542687, level 7.75 m. • B-D - Parareteograptus turgidus Mu, 1993: B - USNM 542852, level 11.70 m; C - USNM 542695, level 10.80 m; D - USNM 542724, level $11.70 \mathrm{~m} . \bullet \mathrm{G}$ - Parareteograptus parvus Mu, 1982: USNM 542801, level 10.30 m. • I, Diplograptus rigidus (Lee in Wang, 1974): USNM 542706, level 11.70 m. • J, N-P - Diplograptus rarithecatus (Ross \& Berry, 1963): J - USNM 542857, level MR 105.2 m; N - USNM 542773, level MR 105.2 m; O - USNM 542748, level MR 112.8 m; P - USNM 542798, level 10.30 m. • USNM 542684, 542687, 542714, 542763 and 542845 from the ornatus Biozone, USNM 542695, 542706, 542724, 542748, 542771, 542773, 542798, 542801, 542852,542856 and 542857 from the pacificus Biozone. USNM 542684, 542687, 542695, 542706, 542714, 542724, 542798, 542801, 542845 and 542852 from the Vinini Creek section, USNM 542748, 542763, 542771, 542773, 542856 and 542857 from the Martin Ridge section. Figures A, B, F, I-P × 6, figures C-E, G, H × 10. Scale bars equal $1 \mathrm{~mm}$. 
Petr Štorch et al. • Uppermost Ordovician graptolites of north-central Nevada
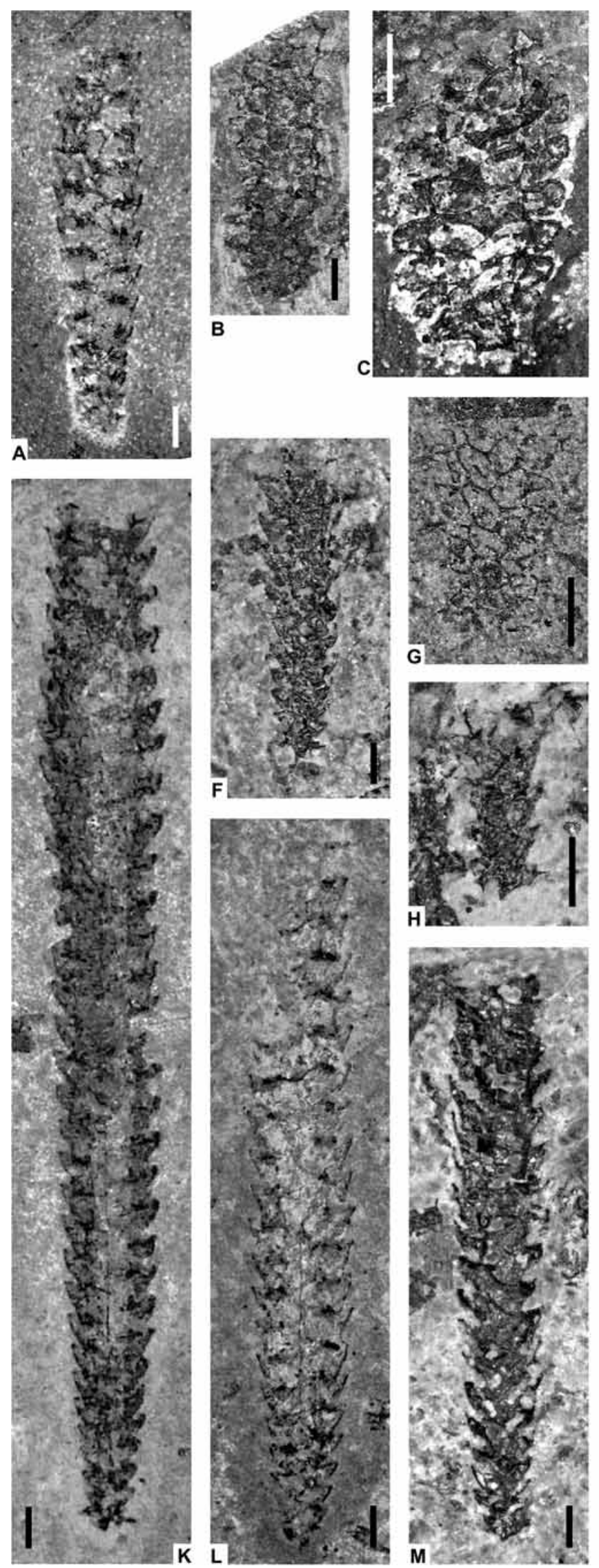
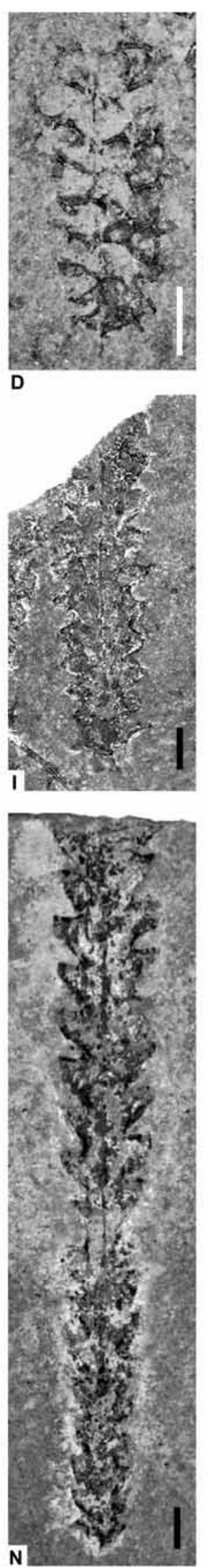
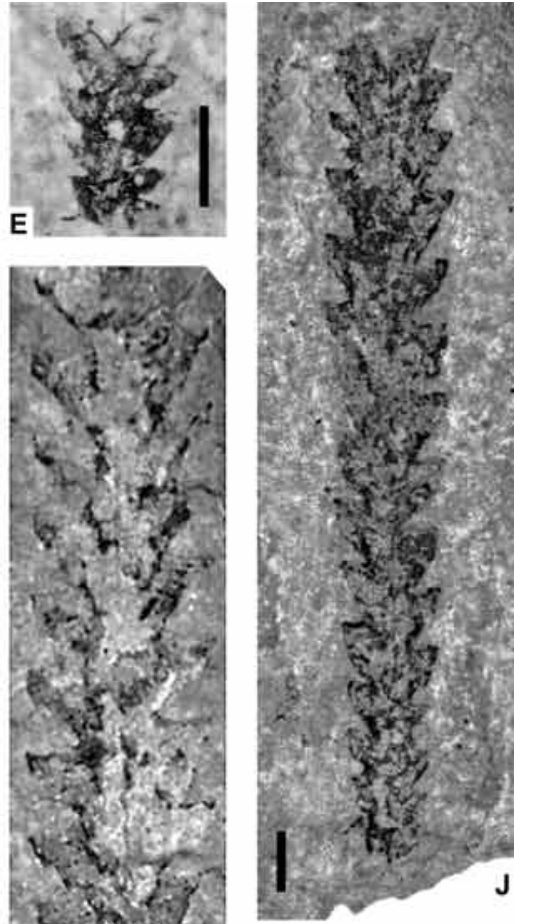

(5)
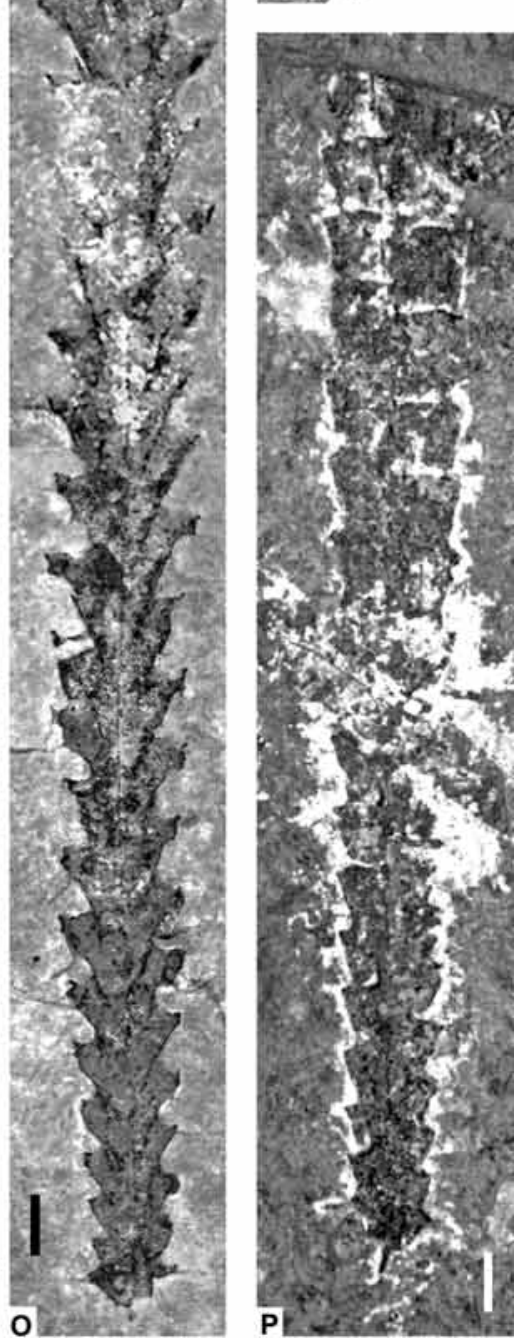
Remarks. - Uniform width and densely packed thecae of present specimens are consistent with $P$. uniformis described by Mu \& Li in Mu \& Lin (1984), Mu et al. (1993) and Chen et al. (2005a) and enable its distinction from Po. pacificus. Genicular spines are less prominent than those in Po. pacificus. In contrast to Chinese sections, our Po. uniformis makes its first appearance well in the pacificus Zone and suggests that the species did not evolve within the Hirnantian mass extinction interval as suggested by Chen et al. (2000, 2005b).

\section{Genus Anticostia Stewart \& Mitchell, 1997, emend. herein}

Type species. - Anticostia macgregorae Stewart \& Mitchell, 1997; pp. 221-225, figs 5A-M, pl. 1; by original designation.

Definition. - Paraphyletic taxon comprising species descending from the common ancestor of An. macgregorae Stewart \& Mitchell, 1997 and An. decipiens (Riva, 1988) and all its descendents (node 3, Fig. 6), excluding Parareteograptus sinensis and species sharing a more recent ancestry with $P r$. sinensis than with An. macgregorae.

Description. - The synapomorphy that unites this small clade (including Parareteograptus) is the Pattern K proximal structure (Stewart \& Mitchell, 1997). Species of Anticostia formed colonies with fully developed thecae (that is, non-retiolite type thecae as in Parareteograptus) of amplexograptid to glyptograptid form with a very short interthecal septum. Most have thecae with prominent apertural lappets but that feature appears to be retained from their amplexograptid-rectograptid ancestors. Colonies possess a strongly upwardly grown first thecal pair and little or no gap between the descending and upward-grown parts of th $1^{1}$ in obverse view. All known Anticostia species are aseptate with the nema either entirely free or only weakly linked to lateral walls by occasional lists.

Included species. - In addition to the species included by Stewart \& Mitchell, the taxon as emended here is expanded to include a number of Amplexograptus-like species with pattern K proximal structure: Amplexograptus prominens Barrass, 1954, Amplexograptus elongatus Barrass, 1954, Climacograptus latus Elles \& Wood, 1908, Glyptograptus uniformis $\mathrm{Mu} \& \mathrm{Lin}$ (in Mu et al. 1993), and Paraclimacograptus decipiens Riva, 1988.

Remarks. - The genus Anticostia was established to encompass a small group of species with variously orthograptid to glyptograptid thecal profile, strong apertural lappets, a Pattern K proximal structure (Stewart \& Mitchell 1997), and retaining a tightly upturned first thecal pair with a mesial spine on th $1^{1}$ similar to that in Rectograptus and Paraorthograptus. Phylogenetic analysis (Mitchell et al. 2007b; see Fig. 6 herein) indicates that the group of Pattern K-bearing, late Katian Amplexograptus-like species (e.g., "Am." prominens, "Am." elongatus, and "C." latus) form a stem lineage to Anticostia as originally defined and are widely removed from the phylogenetic position of Amplexograptus perexcavatus (the type species of Amplexograptus) and its close sister species (e.g., Am. maxwelli and Am. praetypicalis). Thus, as currently employed the genus Amplexograptus is polyphyletic and the pattern K-bearing " $\mathrm{Cli}$ macograptus latus" and relatives cannot be retained in the genus Amplexograptus. In addition, among the species originally included in Anticostia, Glyptograptus tenuissimus, Ross \& Berry 1963, exhibits distinctly geniculate proximal thecae that become increasingly glyptograptid distally (Stewart \& Mitchell 1997, fig. 5N-S; see also Fig. 14U herein). This species links the fully amplexograptid forms of "Am." prominens and relatives to the fully glyptograptid An. macgregorae. Accordingly, we recommend transferring all these species to Anticostia rather than erecting yet another paraphyletic genus (which, in this case would be quite difficult to diagnose uniquely).

The suite of species referred here to Anticostia exhibit a range of thecal forms as mentioned above, and they also display some significant variation in internal structure, especially in the form of the interthecal septum and structures supporting the nema. The primitive condition for advanced diplograptids appears to be most like that seen in Rectograptus. The interthecal septum is relatively long and terminates in a distinct aboral list (Fig. 17C, see also Goldman \& Bergström 1997, pl. 2, figs 4-8). In these graptolites the nema appears to be free within the rhabdosome and upon flattening often exhibits a wandering course. In contrast, in species of Geniculograptus and Paraorthograptus this long interthecal septum is linked to the nema via $\mathrm{V}$-shaped aboral list (Fig. 17G). This arrangement appears to revert to the primitive condition through a series of steps within Anticostia. An. decipiens and An. prominens retain long interthecal septa (Fig. 17E) that are linked to the sicula and nema in early thecae but that become separated from the nema distally (see Barrass 1954, fig. 5; Riva 1988, fig. 2O, $\mathrm{P}$ - note lateral offset of nema from colony axis). In the more derived anticostiids (e.g., An. lata, An. fastigata and An. macgregorae), the nema is entirely free above the apex of the sicula except that intermittently it is linked to either the obverse or reverse lateral wall (varies among specimens but not within) by a strap-like bar (Fig. 17B, H) and again the nema often has a wandering course in flattened specimens (e.g., Riva 1988, fig. $2 \mathrm{~B}-\mathrm{D}, \mathrm{K})$. In these species the interthecal septum became very short and the aboral list strongly thickened, arch-like (Fig. 17B, F), eventually transforming into a 
Petr Štorch et al. • Uppermost Ordovician graptolites of north-central Nevada

Table 8. Anticostia fastigata. Dimensions of illustrated specimens (in mm) and type specimens of Glyptograptus altus Ross \& Berry, 1963.

\begin{tabular}{|c|c|c|c|c|c|c|c|c|c|c|}
\hline \multirow{2}{*}{ Taxon } & \multirow{2}{*}{ Specimen USNM } & \multirow{2}{*}{ Text-figure and/or plate } & \multicolumn{4}{|c|}{$\mathrm{W}$} & \multicolumn{4}{|c|}{ 2TRD } \\
\hline & & & th1 & th5 & th10 & dist. max & th2 & th5 & th10 & dist. Th \\
\hline \multirow[t]{4}{*}{ Anticostia fastigata } & 542677 & $14 \mathrm{~A}, 19 \mathrm{~K}$ & 1.0 & 1.5 & - & - & 1.45 & 1.6 & - & - \\
\hline & 542811 & $14 \mathrm{C}, 19 \mathrm{P}$ & 0.75 & 1.2 & 1.5 & - & 1.45 & 1.6 & 1.9 & - \\
\hline & 542686 & 19B & 0.95 & 1.25 & 1.75 & 2.95 & 1.15 & 1.45 & 1.6 & 2.3 \\
\hline & 542722 & $19 \mathrm{~N}$ & $?$ & 1.2 & $?$ & - & 1.05 & 1.35 & - & - \\
\hline \multirow[t]{2}{*}{ Glyptograptus altus } & 138675a-hol. & (R \& B; pl. 11, fig. 1) & 0.85 & 1.25 & 1.76 & 2.5 & 1.29 & 1.39 & 1.52 & 2.0 \\
\hline & 138677 - par. & (R \& B; pl. 11, fig. 2) & 1.0 & 1.69 & 2.2 & 2.88 & 1.3 & 1.53 & 1.97 & 2.2 \\
\hline
\end{tabular}

post-apertural list (located at the back of the thecal aperture and continuous with the thickened rim of the aperture) in distal thecae (Fig. 17A, H). The sweeping fusellar unconformity that marks the boundary between successive thecae is anchored at the lateral ends of the aboral list and in many of these species is strongly thickened - an initial step toward the zigzag dorsal list of Parareteograptus.

As we discuss more fully below, the retiolite-type graptolite Parareteograptus appears to be derived from an anticostiid ancestor very similar to An. fastigata by accentuation of the zigzag list already begun in derived anticostiids and by addition of ventral lists and further reduction in the fusellar thecal walls. Separation of this taxon from Anticostia renders the latter paraphyletic. In this conception of the genus, Anticostia is sister to Paraorthograptus and is a stem lineage to Parareteograptus.

\section{Anticostia fastigata (Davies, 1929)}

Figures 14A, C, 19B, K, N, P, Table 8

1929 Orthograptus fastigatus; Davies, p. 4, text-figs 3-5.

1963 Glyptograptus altus n. sp.; Ross \& Berry, pp. 139, 140, pl. 11, figs 1, 2.

1970 Diplograptus fastigatus (Davies). - Toghill, p. 21, pl. 14, figs 1-9.

1982 Orthograptus fastigatus Davies. - Williams, pp. 40, 41, pl. 4, figs 1-6.

1987 Orthograptus fastigatus Davies, 1929. - Melchin, pp. 198, 200; pl. 2, figs 1-7, 9.

1993 Orthograptus sextans Li (sp. nov.); Li in Mu et al., pp. 195, 349, pl. 43, figs 12, 13.

2002 Orthograptus fastigatus Davies. - Mu et al., pp. 601, 602 , pl. 170, fig. 3 .

Material and stratigraphical range. - 14 flattened rhabdosomes from ornatus and pacificus biozones of the Vinini Creek section. Present in varied limestones, lime mudstones and mudstones.

Description. - Robust, up to $68 \mathrm{~mm}$ long rhabdosome widens gradually from $0.75-1.0 \mathrm{~mm}$ at th1, through
$0.95-1.15 \mathrm{~mm}$ at th 3 and $1.2-1.5 \mathrm{~mm}$ at th 5 to $1.5-1.8 \mathrm{~mm}$ at th10. Maximum width of $2.95 \mathrm{~mm}$ attained very gradually by end of longest specimen. Proximal astogeny matches that in other derived diplograptids: U-shaped th $1^{1}$ with mesial spine that complements virgella and tiny antivirgellar spines derived from concave sicular aperture. Ascending part of th $1^{1} 0.6 \mathrm{~mm}$ long. Thecae alternating, straight, inclined $20-30^{\circ}$ to rhabdosome axis. Thecal apertures slightly introverted, excavation depth $c a$ one-third rhabdosome width. Thickened apertural margin slightly undulating to cuspate due to the presence of lateral apertural lappets, although these are only visible in some flattened specimens. Proximal thecae rather densely packed; 2TRD $2: 1.05-1.45 \mathrm{~mm}, 2 \mathrm{TRD}_{5}: 1.35-1.6 \mathrm{~mm}$ and $2 \mathrm{TRD}_{10}$ : 1.6-1.9 mm. Late distal thecae number 9 in $10 \mathrm{~mm}$ $\left(2 \mathrm{TRD}_{\text {dist }}: 2.1-2.4 \mathrm{~mm}\right)$.

Remarks. - Ross \& Berry (1963) described the taxon Glyptograptus altus n. sp. from the Vinini Formation west of Marys Creek in northern Eureka county (collections USGS D480a, d, e). Although slightly deformed, this material exhibits a form and dimensions that match those of Anticostia fastigata (Table 7). The holotype and paratype of G. altus (USNM 138675a, 138677, respectively) very clearly exhibit the adpressed thecal form of the group, plus strong aboral lists and, distally, zigzag dorsal lists. Indeed, Anticostia fastigata easily can be mistaken for Parareteograptus sinensis $\mathrm{Mu}$ depending on the mode of preservation. Rhabdosome shape and dimensions are nearly the same. Also the thecae are closely similar - regularly alternating, closely adpressed and weakly cuspate. Apertures appear to be lunate in cross section, somewhat extended into the obverse and reverse sides of the rhabdosome, which slightly resembles cypress tree branchlet. Rhabdosome walls are thicker in An. fastigata and zigzag lists connecting thecal apertures are weakly developed and seen only with a favourable mode of preservation. The proximal end is more blunt in Pr. sinensis, which is also recognizable by a deeply incised sicular aperture and by the presence of longitudinal ventral lists that connect successive thecae.

The proximal part of An. fastigata, up to the level of $\sim 5^{\text {th }}$ thecal pair, closely resembles An. uniformis. Thereafter 
Table 9. Anticostia lata. Dimensions of illustrated specimens (in mm).

\begin{tabular}{llllllllll}
\hline \multirow{2}{*}{ Specimen } & \multirow{2}{*}{ Text-figure } & \multicolumn{4}{c}{ W } & \multicolumn{5}{c}{ 2TRD } \\
\cline { 3 - 9 } & & th1 & th5 & th10 & dist. max & th2 & th5 & th10 & dist. th \\
\hline 542681 & $14 \mathrm{G}, 19 \mathrm{~T}$ & 0.8 & 1.0 & 1.4 & 1.75 & $?$ & 1.65 & 1.7 & 1.95 \\
542850 & $14 \mathrm{O}, 19 \mathrm{O}$ & 0.85 & 1.25 & 1.6 & - & 1.35 & 1.75 & 1.85 & - \\
542849 & $14 \mathrm{Y}$ & 0.8 & $?$ & 1.45 & 1.7 & 1.3 & $?$ & 1.6 & 1.9 \\
542744 & $19 \mathrm{H}$ & 0.78 & 1.0 & 1.45 & - & 1.2 & 1.3 & 1.7 & - \\
542682 & $19 \mathrm{I}$ & 0.85 & 1.2 & 1.55 & - & 1.25 & 1.55 & $?$ & - \\
542727 & $19 \mathrm{~J}$ & 0.9 & 1.25 & 1.6 & - & 1.25 & 1.4 & - & - \\
542668 & $19 \mathrm{M}$ & 0.8 & 1.05 & 1.4 & - & 1.3 & 1.35 & - & - \\
\hline
\end{tabular}

the dorsoventral width of An. fastigata increases steadily to the distal maximum of $2.95 \mathrm{~mm}$ whereas the rhabdosome width of An. uniformis remains almost uniform after th5. Distal thecae are widely spaced in An. fastigata $\left(2 \mathrm{TRD}_{\text {dist }}\right.$ : 2.1-2.4 mm) in contrast to the maximum of $1.8 \mathrm{~mm}$ in An. uniformis.

\section{Anticostia lata (Elles \& Wood, 1906)}

Figures 14G, O, Y, 19H-J, M, O, T, Table 9

1906 Climacograptus latus sp. nov.; Elles \& Wood, p. 204, pl. 27, figs 3a-e, ?f, h; text-figs 135a-d.

1929 Diplograptus modestus var. intensus; Davies, p. 5, text-fig. 6.

1933 Climacograptus latus Elles \& Wood. - Sun, p. 21, pl. 3, fig. 5a-d.

1933 Climacograptus inuiti; Cox, p. 1, pls 1, 2.

1962 Climacograptus suni; $\mathrm{Mu}$, p. 57, pl. 22, figs 11, 12.

1970 Climacograptus latus Elles \& Wood. - Toghill, p. 22, pl. 15, figs 1, 2 .

1973 Amplexograptus stukalinae; Mikhaylova, p. 17, pl. 4, figs 1, 2.

1974 Amplexograptus disjunctus yangtzensis; Mu \& Lin (in Nanjing Institute of Geology and Palaeontology ed.), p. 162, pl. 70, fig. 6 .

1980 Amplexograptus stukalinae Mikhaylova, 1973. Koren' et al. (in Apollonov et al.), pp. 125, 126, pl. 34, figs 1-5; text-fig. 31 .
1982 Climacograptus latus Elles \& Wood. - Williams, p. 39, pl. 3, figs $12-18$.

1983 Climacograptus latus hekadaensis subsp. n.; Koren' \& Sobolevskaya, pp. 116, 117, pl. 30, figs 2-6; pl. 31, figs $1-3$; text-fig. 39a-ж.

1987 Climacograptus latus Elles \& Wood. - Melchin, p. 196, pl. 1, figs 3-8.

1988 Amplexograptus latus (Elles \& Wood). - Riva, pp. 226, 228, 229; text-figs 2a-h, 4.

1993 Amplexograptus regularis; Mu \& Lin (in Mu et al.), pp. 141, 142, pl. 23, figs 1-3.

1993 Amplexograptus gansuensis yichangensis; Mu \& Lin (in $\mathrm{Mu}$ et al.), p. 142 (partim), pl. 23, fig. 6 (non pl. 23, figs 4, 5, 7-9).

1993 Amplexograptus disjunctus yangtzensis; Mu \& Lin (in Mu et al.), pp. 142-144, pl. 22, figs 5-18; text-figs 18a-j, 19.

1993 Amplexograptus inuiti (Cox). - Mu et al., pp. 144, 145, pl. 23, figs 14-21.

1993 Amplexograptus suni (Mu). - Mu et al., pp. 145, 146, pl. 24, figs 1-14 (see for further reference on $A$. suni).

2002 Geniculograptus latus (Elles \& Wood). - Mu et al., pp. 538, 539, pl. 154, figs 21, 22.

2005a Amplexograptus latus (Elles \& Wood, 1906). - Chen et al., p. 243, pl. 2, fig. 3; text-fig. 3K, O.

Material and stratigraphical range. - The species is common in ornatus and pacificus biozones at the Vinini Creek

Figure 16. A, C, Q-Paraplegmatograptus uniformis Mu, 1978: A - USNM 542705, level $11.70 \mathrm{~m}$; C-USNM 542766, level MR $105.2 \mathrm{~m}$; Q - USNM 542769, level $105.2 \mathrm{~m}$. • B, E, F - Phormograptus connectus (Mu, 1984): B - USNM 542742, level MR $95.00 \mathrm{~m}$, E - USNM 542848, level 4.40 m; F - USNM 542709, level $11.70 \mathrm{~m}$ • D, G, H - Paraorthograptus uniformis Mu \& Li, 1984: D - USNM 542806, level 27.85 m; G - USNM 542776, level $105.2 \mathrm{~m}$; H - USNM 542774, level MR $105.2 \mathrm{~m}$. • I, O, P - Yinograptus disjunctus Yin \& Mu, 1945: I - USNM 542702, level 11.70 m; O - USNM 542767, level MR 105.2 m; P - USNM 542662, level $4.40 \mathrm{~m}$. J-L, R-U - Rectograptus abbreviatus (Elles \& Wood, 1907): J - USNM 542743, level MR $95.00 \mathrm{~m}$; K - USNM 542731, level $9.80 \mathrm{~m}$; L - USNM 542725a, level $7.65 \mathrm{~m} ; \mathrm{R}$ - USNM 542707, level $11.70 \mathrm{~m}$; S - USNM 542745a, T - USNM 542745b, level MR 90.20 m; U - USNM 542676, level 17,60 m. • M, N -Paraorthograptus pacificus (Ruedemann, 1947): M - USNM 542697, level $10.80 \mathrm{~m}$; N - USNM 542791, level $10.30 \mathrm{~m}$. - USNM 542662, 542725, 542742, 542743, 542745a, b and 542848 from the ornatus Biozone, USNM 542676, 542697, 542702, 542705, 542707, 542709, 542731, 542766, 542767, 542769, 542774, 542776 and 542791 from the pacificus Biozone and USNM 542806 from the persculptus Biozone. A, D-F, I, K-N, P, R, U from the Vinini Creek section, B, C, G, H, J, O, Q, S, T from the Martin Ridge section. All figures $\times 6$. Scale bar equals $1 \mathrm{~mm}$. 
Petr Štorch et al. • Uppermost Ordovician graptolites of north-central Nevada

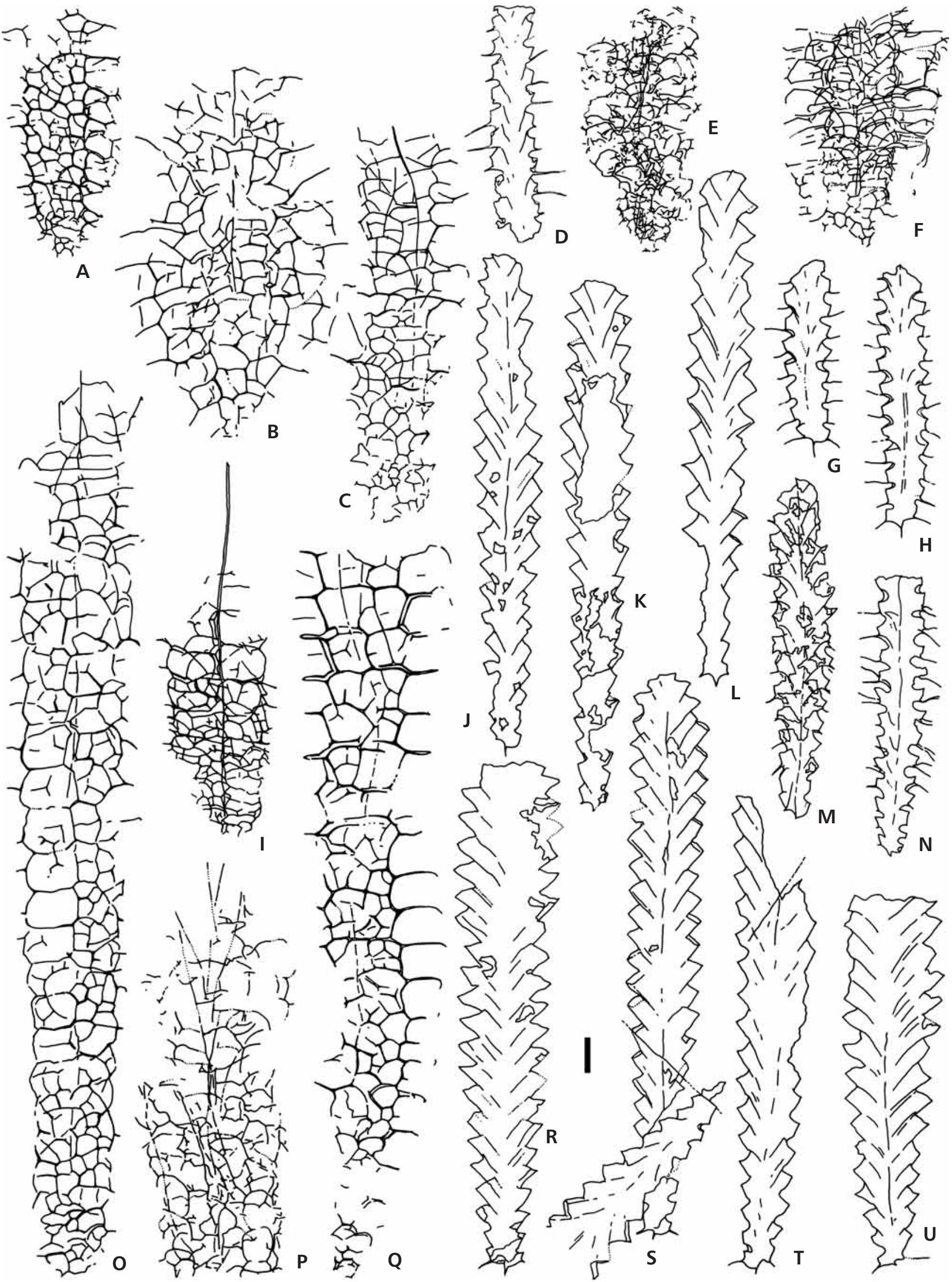


and Martin Ridge sections. Twenty of more than 40 specimens have been measured in detail. The generally flattened specimens came from varied limestone, mudstone and black shale lithologies.

Description. - Rhabdosome long, robust, gradually widening from $0.8-0.95 \mathrm{~mm}$ at th1 to $1.0-1.25 \mathrm{~mm}$ at th5, $1.35-1.6 \mathrm{~mm}$ at th10 and $1.5-1.7 \mathrm{~mm}$ at th20. Maximum width ranging from $1.8 \mathrm{~mm}$ to $2.25 \mathrm{~mm}$ in mature rhabdosomes, about $25 \mathrm{~mm}$ from the proximal end. Sicula poorly exposed but virgella generally prominent and one of two antivirgellar spines commonly projects stiffly from the base of th $1^{2}$. Th $1^{1}$ extends below the sicular aperture before it turns and grows upwards for $0.4-0.6 \mathrm{~mm}$. Th1 ${ }^{1}$ bears a sub-ventrally directed mesial spine. Thecae possess strong geniculum, further enhanced by a prominent flange. Thecal apertures bear lateral lappets and face into rather short (0.15-0.3 mm proximally and $0.25-0.3 \mathrm{~mm}$ distally) and deep excavations that occupy $c a$ one-third rhabdosome width. Relatively short supragenicular walls $(0.4-0.55 \mathrm{~mm}$ proximally, $0.52-0.65 \mathrm{~mm}$ distally) inclined at $1-5^{\circ}$ to rhabdosome. Proximal thecae densely spaced $\left(2 \mathrm{TRD}_{2}: 1.2-1.7 \mathrm{~mm}\right.$, $2 \mathrm{TRD}_{5}: 1.3-1.75 \mathrm{~mm}$ and $2 \mathrm{TRD}_{10}: 1.5-1.9 \mathrm{~mm}$ ), distal thecae number $10-12$ in $10 \mathrm{~mm}\left(2 \mathrm{TRD}_{\text {dist }}: 1.6-2.1 \mathrm{~mm}\right)$.

Remarks. - The species is here transferred to Anticostia Stewart \& Mitchell. Strong thecal geniculation accentuated by a thickened rim is the most prominent feature differentiating An. lata (Elles \& Wood, 1906) from the very similar Anticostia tenuissima (Ross \& Berry, 1963). Williams (1982) and Riva (1988) provided detailed discussions of the extensive synonymy of this widespread species.

\section{Anticostia macgregorae Stewart \& Mitchell, 1997} Figures 14L, 19A
cf. 1983 Glyptograptus lorrainensis (Ruedemann, 1925). - Koren' et al., pp. 141, 142, pl. 51, figs 4-6; text-fig. $52 \mathrm{a}-\mathrm{g}$.
1997 Anticostia macgregorae n. gen., n. sp.; Stewart \& Mitchell, pp. 221-225, pl. 1, text-figs 4, 5A-M.

Material and stratigraphical range. - Single rhabdosome from the ornatus Zone of the Vinini Creek section is preserved in relief in sparry limestone.

Remarks. - Generally slender rhabdosome is characterized by its relatively broad proximal end $(0.95 \mathrm{~mm}$ at first thecal pair), followed by a distinct narrowing at the second thecal pair (width $-0.8 \mathrm{~mm}$ ) as well as rather widely spaced thecae without significant geniculum. Subsequent gradual widening of the rhabdosome attains $1.2 \mathrm{~mm}$ at th8, just before the distal end of the present rhabdosome. Th $1^{1}$ is broadly U-shaped, $0.62 \mathrm{~mm}$ high, furnished with a prominent mesial spine. The thecae are straight, and slightly longer than those of Anticostia uniformis. The $2 \mathrm{TRD}_{5}$ is $1.85 \mathrm{~mm}$ as oppose to $1.3-1.8 \mathrm{~mm}$ in the latter species. Ventral thecal walls are inclined $8-15^{\circ}$ to the rhabdosome. Thecal apertures are slightly introverted with lateral lappets and occupy one-third the rhabdosome width.

\section{Anticostia tenuissima (Ross \& Berry, 1963)}

Figures 14N, U-X, 19E-G, Q, R, Table 10

1963 Glyptograptus tenuissimus; Ross \& Berry, p. 141, pl. 11 , fig. 6.

Figure 17. Comparison of colony structure among species here included within Anticostia, Paraorthograptus and Rectograptus. $\bullet$ A, B, F - Anticostia macgregorae Stewart \& Mitchell, 1997, Sample A297 4.0 m, Vauréal Formation, Anticosti Island, Quebec, Canada (Di. ornatus Zone equivalent; see Stewart \& Mitchell, 1997, for further stratigraphic information): A - oblique view, B - lateral view of distal part of a colony (USNM 542830a) showing very short interthecal septa with strongly thickened aboral lists ("a"). Note well-defined zigzag contact between alternate thecae $\mathrm{N}$ and $\mathrm{N}+1$, which anchored at the aboral list slightly below the aperture of theca N-1. Nema largely free but occasionally attached to lateral wall by broad list ("b"). • F proximal portion of colony (USNM 542830c) with zigzag contact also anchored slightly below thecal aperture, but well above aboral list ("a"). - C - Rectograptus intermedius (Elles \& Wood, 1907): USNM 542831, Viola Springs Formation, exposure along US Highway 77, Fitztown, Oklahoma, USA (C. bicornis Zone; for further stratigraphic information see Finney 1986 and Goldman et al. 2007b) - reverse view showing Pattern G proximal structure (note gap between descending and ascending part of th $1^{1}$ ), succession of alternate theca, increasingly longer interthecal septa with aboral lists ("a"), and free nema. • D, E - Anticostia decipiens (Riva, 1988): sample AP6-5, Vauréal Formation, Anticosti Island, Quebec, Canada (Di. ornatus Zone equivalent; for further stratigraphic information see Riva 1988): D - obverse view, proximal fragment (GSC 134831) showing attachment of interthecal septa to sicula followed by retreat away from location of the free nema (torn away during dissolution). This condition is intermediate between that shown in the more derived Anticostia macgregorae and the likely ancestral condition displayed in Paraorthograptus (14G) and Geniculograptus (see Bulman 1932, pl. 5). E - colony fragment (GSC 134830) showing Pattern K proximal structure; note lack of gap between descending and ascending part of th 1 as well as large upward-grown th $1^{2}$ flange that meets shelf at arrow ("a"), forming a broad base for the th $2^{1}$ protheca. • G - Paraorthograptus pacificus (Ruedemann, 1947) = Po. brevispinus Mu \& Li, 1982 of Melchin (1987), Cape Phillips Formation, Truro Island, Canadian Arctic Islands (Po. pacificus Zone, for additional stratigraphic details see Melchin 1987); reverse view of GSC 104924. Note Pattern G proximal structure, long interthecal septa attached to nema by aboral lists. Thecae lack well defined zigzag alternation. • H - Anticostia lata (Elles \& Wood, 1906), USNM 542832, from type block of Climacograptus inuiti Cox, 1933, Akpatok Island, Arctic Islands, Canada (horizon uncertain but probably Po. pacificus or Di. ornatus zone equivalent); distal portion of colony with thecal structure and nema condition as in An. macgregorae (17A, B), but with prominent genicular flanges. Scale bars $=0.5$ mm. All are chemically isolated specimens imaged with transmitted infrared light ( $880 \mathrm{~nm}$ ) using a digital CCD camera (see Melchin \& Anderson 1998). 
Petr Štorch et al. • Uppermost Ordovician graptolites of north-central Nevada
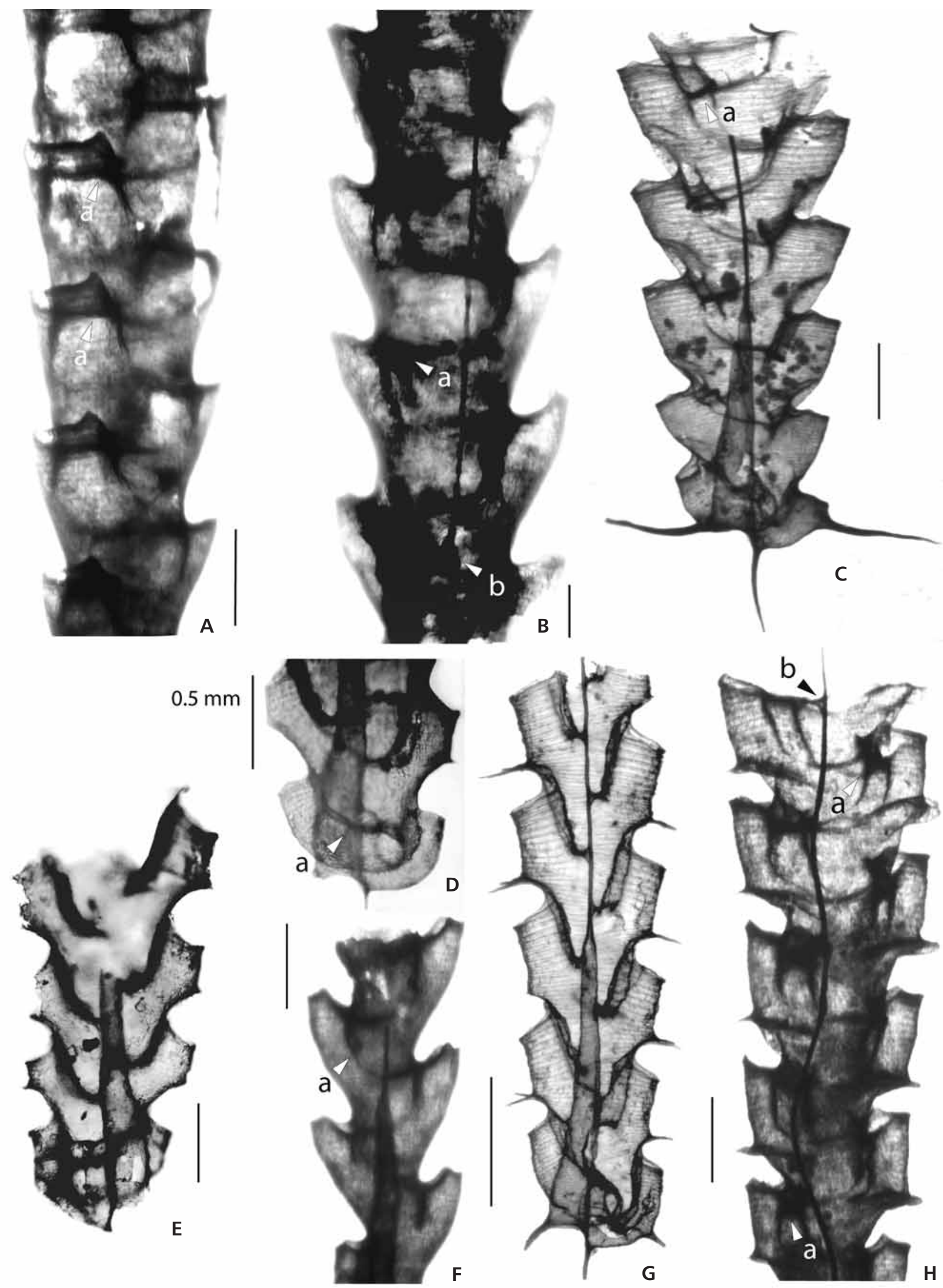
?1969 Glyptograptus lorrainensis Ruedemann. - Riva, figs $6 \mathrm{e}, \mathrm{f}$.

1973 Glyptograptus cf. G. lorrainensis (Ruedemann). Jackson, p. 4, figs 2a, 3a-c, e-g.

1987 Glyptograptus cf. G. lorrainensis (Ruedemann). Melchin, p. 198, pl. 1, figs 16-20.

1997 Anticostia tenuissima (Ross \& Berry); Stewart \& Mitchell, p. 225, figs 5N-S.

Material and stratigraphical range. - The species, confined to the ornatus Zone in both the Vinini Creek and Martin Ridge sections, is particularly common in a decalcified mudstone at $96.1 \mathrm{~m}$ of the latter section. Seventeen of more than 30 specimens at our disposal have been measured in detail. Generally flattened specimens came from limestones, lime-mudstones and mudstones.

Description. - Rhabdosome widens gradually from its rounded, somewhat asymmetric, proximal end; $0.7-0.9 \mathrm{~mm}$ wide at th1, 0.95-1.35 $\mathrm{mm}$ at th5, 1.3-1.55 $\mathrm{mm}$ at th10, and maximum of $1.35-1.8 \mathrm{~mm}$ by about th $15-$ th 19 becoming parallel sided distally in longest specimens $(\sim 30 \mathrm{~mm})$. Sicula fully covered by th $1^{2}$ in reverse view; aperture $0.15-0.25 \mathrm{~mm}$ wide, and with tiny virgella and ventroproximally directed antivirgellar spines. First thecae strongly upturned and rather short $(0.4-0.55 \mathrm{~mm})$; th $1^{1}$ possesses a prominent mesial spine. Subsequent thecae of glyptograptid appearance when flattened and more geniculate when preserved in slight relief in limestone. Supragenicular walls short $(0.35-0.5 \mathrm{~mm}$ in proximal thecae, $0.5-0.6 \mathrm{~mm}$ in distal thecae), inclined at 5-25 to the rhabdosome, depending on preservation. Distal thecae overlap for one-third to half their length. Thecal apertures with weak lappets and horizontal to slightly introverted; excavations occupy $1 / 3$ rhabdosome width. Thecae number about seven in proximal $5 \mathrm{~mm}$ of the rhabdosome $\left(2 \mathrm{TRD}_{2}: 1.0-1.3 \mathrm{~mm}, \quad 2 \mathrm{TRD}_{5}\right.$ : $1.35-1.65 \mathrm{~mm})$; distal thecae number $11-12.5$ in $10 \mathrm{~mm}$ $\left(2 \mathrm{TRD}_{\text {dist }}: 1.6-1.85 \mathrm{~mm}\right)$.

Remarks. - Anticostia tenuissima is readily distinguishable from other species of this genus by its glyptograptid thecae with a bluntly rounded geniculum and deeply incised thecal apertures that occupy one-third the rhabdosome width. The rhabdosome gently widens to $1.35-1.8 \mathrm{~mm}$ through the proximal $10-12 \mathrm{~mm}$ and then becomes parallel-sided. Proximal end is rounded and markedly asymmetrical. The th $1^{1}$ is furnished with mesial spine but lacks u-shape appearance typical of Anticostia uniformis (Mu \& Lin), An. macgregorae Stewart \& Mitchell and, to a lesser degree, An. fastigata (Davies). The rhabdosome widens through the second and third thecal pair and thus lacks gentle bottleneck profile observed in other anticostiids.

\section{Anticostia thorsteinssoni (Melchin, 1987) \\ Figures 14D, 19S}

1987 Orthograptus thorsteinssoni n. sp.; Melchin, p. 200, pl. 2, figs 8, 10, 12 .

Material and stratigraphical range. - One rhabdosome moderately well preserved in sparry limestone, Di. ornatus Zone of the Vinini Creek section.

Description. - Single immature rhabdosome, $5.3 \mathrm{~mm}$ long, bears prominent virgella and two long $(1.8 \mathrm{~mm})$ and robust, laterally directed basal spines - antivirgellar sicular spine on one side and mesial spine of thl ${ }^{1}$ opposite. Rhabdosome $0.95 \mathrm{~mm}$ wide at th 1 and $1.3 \mathrm{~mm}$ wide at th5. Thecae straight, alternating with little overlap; apertures slightly introverted with lateral lappets, occupy one-third of rhabdosome width. Ventral thecal walls incline at $25-30^{\circ}$ to rhabdosome axis. 2TRD $1.3 \mathrm{~mm}$ at th2 and $1.9 \mathrm{~mm}$ at th5.

Remarks. - Both early astogeny and thecae are typically anticostiid. An. thorsteinssoni may be distinguished from the otherwise most similar An. fastigata by its prominent basal spines. Virgella is either small or broken in our specimen.

\section{Anticostia uniformis (Mu \& Lin) in Mu et al., 1993}

Figures 14E, F, M, 19C, D, L, Table 11

1983 Glyptograptus tenuissimus Ross \& Berry, 1963. Koren' et al., p. 148, pl. 44, figs 1-4; text-fig. 55a-d.

1993 Glyptograptus uniformis; Mu \& Lin (in Mu et al.), p. 134, pl. 26, figs 8-10; text-fig. 16a.

1993 Glyptograptus mirus; Mu \& Lin (in Mu et al.), p. 134, pl. 26, figs 11, 12.

2005a Anticostia uniformis (Mu \& Lin). - Chen et al., p. 245 , text-figs $3 \mathrm{H}, \mathrm{P} ; 5 \mathrm{~N}, \mathrm{~W}$.

Material and stratigraphical range. - Rare specimens from the ornatus Zone and the lower pacificus Zone, but fairly common in the upper part of the latter zone at Vinini Creek section. Ten flattened rhabdosomes from brown lime mudstones and mudstones.

Description. - Aseptate, minute, parallel sided rhabdosome characterized by relatively broad proximal end. Broadly $\mathrm{U}$-shaped th $1^{1}$, and pattern $\mathrm{K}$ astogeny barely visible in this material. Maximum observed length of the rhabdosome slightly exceeds $11 \mathrm{~mm}$. Initial width $0.7-1.15 \mathrm{~mm}$ maintained at th2. Maximum width attained at th3 or little higher $(0.85-1.3 \mathrm{~mm}$ at th5, $1.2-1.3 \mathrm{~mm}$ at th10). Sicula largely obscured in reverse view; aperture concave, $\sim 0.2 \mathrm{~mm}$ wide, with tiny virgella and antivirgellar spines. 
Table 10. Anticostia tenuissima. Dimensions of illustrated specimens (in mm).

\begin{tabular}{llccccccccc}
\hline \multirow{2}{*}{ Specimen } & \multirow{2}{*}{ Text-figure } & \multicolumn{4}{c}{ W } & \multicolumn{4}{c}{ 2TRD } \\
\cline { 3 - 9 } & & th1 & th5 & th10 & dist. max & th2 & th5 & th10 & dist. Th \\
\hline 542761 & $14 \mathrm{~N}, 19 \mathrm{Q}$ & 0.75 & 1.3 & - & - & 1.15 & 1.45 & - & - \\
542757 & $14 \mathrm{U}$ & 0.85 & 1.3 & 1.45 & 1.75 & 1.2 & 1.65 & 2.0 & 2.0 \\
$542755 \mathrm{a}$ & $14 \mathrm{~V}, 19 \mathrm{E}$ & 0.7 & 1.1 & 1.35 & 1.35 & 1.05 & 1.35 & 1.6 & 1.5 \\
$542755 \mathrm{~b}$ & $14 \mathrm{~W}, 19 \mathrm{~F}$ & 0.8 & 1.3 & 1.45 & - & 1.2 & 1.5 & 1.75 & - \\
542855 & $19 \mathrm{G}$ & 0.7 & 1.2 & - & - & 1.2 & 1.5 & 1.75 & - \\
542853 & $19 \mathrm{R}$ & 0.7 & 1.2 & 1.45 & 1.75 & 1.05 & 1.6 & 1.6 & 1.85 \\
\hline
\end{tabular}

Table 11. Anticostia uniformis. Dimensions of illustrated specimens (in mm) and thecal inclination (in ${ }^{\circ}$ ).

\begin{tabular}{llcccccccc}
\hline \multirow{2}{*}{ Specimen } & \multirow{2}{*}{ Text-figure } & \multicolumn{4}{c}{ W } & \multicolumn{3}{c}{ 2TRD } \\
\cline { 3 - 9 } & & th1 & th2 & th5 & th10 & th2 & th5 & th10 & Thecal incl. \\
\hline 542812 & $14 \mathrm{E}, 19 \mathrm{C}$ & 1.0 & 0.9 & 1.2 & - & 1.6 & 1.75 & - & $8-17^{\circ}$ \\
542716 & $14 \mathrm{~F}, 19 \mathrm{D}$ & 0.8 & 1.0 & 1.2 & - & 1.5 & 1.7 & - & $8-14^{\circ}$ \\
542672 & 14M, 19L & 1.05 & 1.05 & 1.2 & 1.3 & 1.25 & 1.6 & 1.8 & $13-15^{\circ}$ \\
\hline
\end{tabular}

Ascending part of th $1^{1} 0.35-0.55 \mathrm{~mm}$ long, with small mesial spine. Distance between sicular aperture and that of th $1^{2} 0.5-0.8 \mathrm{~mm}$. Thecae glyptograptid with flowing geniculum, overlap $\sim 1 / 4$ their length and with supragenicular walls inclined at $8-17^{\circ}$. Lappetted, slightly introverted apertures occupy one-quarter to one-third rhabdosome width. The $2 \mathrm{TRD}_{2}: 1.25-1.7 \mathrm{~mm}, 2 \mathrm{TRD}_{5}: 1.3-1.8 \mathrm{~mm}$ and the most distal 2TRD: $1.8 \mathrm{~mm}$.

Remarks. - Anticostia uniformis, along with An. macgregorae Stewart \& Mitchell, are typified by a particularly asymmetrical proximal end with broadly U-shaped th $1^{1}$ and, consequently, a slight narrowing of the rhabdosome at the level of the second thecal pair. Chen et al. (2005a) reported a very long sicula in An. uniformis, with apex attaining the level of apertures of the fourth thecal pair. The sicula is barely visible in our material but An. macgregorae differs from An. uniformis also in having relatively longer, more widely spaced thecae. An. uniformis and An. macgregorae occur in the same stratigraphic level, typically higher than An. tenuissima.

\section{Genus Parareteograptus Mu, 1974, emend. herein}

Type species. - Parareteograptus sinensis Mu, 1974; pp. 163,164 , pl. 70 , fig. 13; by original designation.

Definition. - Parareteograptus sinensis and all species that share a more recent ancestry with $P$. sinensis than with A. macgregorae.

Description. - Derived diplograptids with reticulate rhabdosome in which continuous fusellar walls largely reduced to thickened lists that outline thecae in somewhat stylized manner. Depending on preservation, specimen maturity, and variation among species, some rhabdosomes also covered by thin sheets. Proximal end shape strongly anticostiid in form. Th $1^{1}$ tightly U-shaped with short upright ascending part and prominent subapertural to mesial spine. Th1 ${ }^{2}$ also strongly upright but without spine. Sicula generally entirely covered on reverse side; aperture with two antivirgellar spines and deep lateral notch between stout virgella and dorsal side of sicula. Proximal structure is obscure but given above geometry, most likely Pattern K.

Sets of lists corresponding to each theca form roughly pentagonal to triangular panels along the obverse and reverse sides of rhabdosome. Obverse and reverse panels linked by post-apertural lists and hooplike apertural lists that together outline thecal apertures. Thecal apertures are straight, nearly horizontal and without spines (but in flattened preservation broken or deformed apertural lists often give the appearance of spines). Alternating individual lateral panels form a continuous framework or mesh consisting of arched to nearly straight dorsal zigzag lists (in some cases forming more or less continuous median strand), and four lateral strands along colony margins. Lateral strands consist of outwardly inclined ventral lists and short offsetting pleural lists between the post-apertural list and apertural lists. Zigzag dorsal lists may link directly to ventral strands at junction of pleural and post-apertural list or may appear to have short, more or less horizontal "connecting lists," but this varies astogenetically and among species.

Remarks. - Late Ordovician graptolite faunas contain a substantial number of retiolite-type graptolites and these appear to have a diverse set of origins. A particularly large group of retiolite-type graptolites, which includes 
Table 12. Dimensions of Wufeng Fm. pararetiograptid specimens (in mm). Name of senior synonym in bold.

\begin{tabular}{|c|c|c|c|c|c|c|c|c|c|c|}
\hline \multirow{2}{*}{ Taxon } & \multirow{2}{*}{ Specimen } & \multirow{2}{*}{ Mu et al. 1993} & \multicolumn{4}{|c|}{$\mathrm{W}$} & \multicolumn{4}{|c|}{ 2TRD } \\
\hline & & & th1 & th5 & th10 & dist. max & th2 & th5 & th10 & dist. Th \\
\hline Orthoretiograptus denticulatus & holotype & fig. 39a & 1.0 & 1.65 & 2.6 & 3.1 & 1.35 & 1.35 & 1.65 & 2.1 \\
\hline Orthoretiograptus denticulatus & paratype & fig. $39 b$ & 0.83 & 1.67 & 2.33 & - & 0.93 & 1.07 & 1.50 & - \\
\hline Parareteograptus sinensis & hypotype & pl. 51, fig. 2 & 1.2 & 2.3 & 2.8 & - & 1.3 & 1.8 & 2.0 & - \\
\hline Parareteograptus sinensis & hypotype & pl. 51, fig. 4 & 0.9 & 2.2 & - & - & 1.0 & 1.6 & - & - \\
\hline Parareteograptus sinensis & hypotype & fig. 37b & 1.27 & 2.17 & 2.5 & 2.6 & 1.07 & 1.27 & 1.73 & 1.67 \\
\hline Parareteograptus magnus & hypotype & pl. 52, fig. 6 & 1.25 & 2.1 & 1.87 & 3.0 & 0.95 & 1.3 & 1.8 & 1.9 \\
\hline Parareteograptus magnus & hypotype & fig. 37c & 1.27 & 2.3 & 3.17 & 3.27 & 0.87 & 1.33 & 2.0 & 2.33 \\
\hline Parareteograptus turgidus & holotype & pl. 51, fig. 9 & 1.0 & 2.4 & 2.4 & - & 0.9 & 1.4 & 1.6 & - \\
\hline Parareteograptus turgidus & paratype & pl. 51, fig. 12 & 1.25 & 2.1 & - & - & 0.9 & 1.4 & - & - \\
\hline Parareteograptus turgidus & paratype & fig. $37 \mathrm{e}$ & 1.0 & 2.15 & 1.85 & 1.6 & 1.2 & 1.4 & 1.55 & 1.6 \\
\hline Pseudoreteograptus nanus & holotype & pl. 54, fig. 1 & 1.5 & 2.3 & 2.1 & - & 1.0 & 1.33 & 1.33 & - \\
\hline Parareteograptus parvus & hypotype & pl. 52, fig. 9 & 0.9 & 1.7 & 2.0 & - & 0.9 & 1.2 & 1.7 & - \\
\hline Parareteograptus parvus & hypotype & pl. 53, fig. 12 & 0.9 & 1.3 & 2.1 & 2.1 & 0.9 & 1.1 & 1.2 & 1.2 \\
\hline Parareteograptus parvus & hypotype & fig. 37e & 1.10 & 1.57 & 2.0 & - & 1.0 & 1.27 & 1.73 & - \\
\hline
\end{tabular}

Plegmatograptus and Nymphograptus and their relatives belong to the Lasiograptidae and will be discussed further below. Another widely distributed group of retiolite-type species belong to the genus Parareteograptus $\mathrm{Mu}$.

The strongly anticostiid form of the proximal end of Parareteograptus sinicus $\mathrm{Mu}$ and the other Parareteograptus species combined with the tendency of Anticostia fastigata to develop list-like thickenings attests to the phylogenetic link between these taxa. List-like structures in An. fastigata develop along the zigzag unconformity between its alternating thecae. These thickened unconformities root at aboral lists that are progressively converted to post-apertural lists along the length of the rhabdosome. The apertural margins are also strongly thickened. Thus, most of the main elements of the Parareteograptus structure are present incipiently in derived anticostiids. Indeed, the structure attributed to Orthoretiograptus (Mu 1978, $\mathrm{Mu}$ et al. 1993) is essentially identical to the derived anticostiid architecture but for the absence in Anticostia rhabdosomes of ventral lists and the resulting lateral strands.

The reported distinction between Orthoretiograptus Mu (in Wang et al,. 1978) and Parareteograptus Mu, 1974 lies in the presence of roughly horizontal connecting lists that link (Fig. 18A, arrow 2) the zigzag diagonal lists to the bundle of lists at the corner of the thecal aperture in Parareteograptus and their absence in Orthoretiograptus (Fig. 18A, arrow 1). This distinction is founded on an abstractly geometrical view of these structures. In fact, as thecae were added to the growing end of the colony, the diagonal and connecting lists develop as a continuous dorsal arch (Fig. 18A, arrow 3), and each successive dorsal list (combined diagonal and connecting list) was anchored onto the previous arch, either very close to the apertural list junction (in which case there is no connecting list, producing the Orthoretiograptus configuration) or a little down the dorsal list from this junction (resulting in the Parareteograptus configuration). The continuity between the diagonal and connecting lists is nicely shown by a three-dimensionally preserved specimen of Pr. sinensis (Fig. 18B, C) from the Wufeng Shale (see also Mu et al. 1993, pl. 51, fig. 8). In this uncompressed specimen the connecting list slopes outward parallel to the thecal. The junction between succeeding diagonal lists and the connecting list forms a deep dimple on the colony surface of this specimen producing a configuration that is closely similar to that in Anticostia thecae. Based on homology with Anticostia, this list junction probably corresponds to the base of the interthecal septum and location of the internal post-apertural list is not at the posterior edge of the thecal aperture as shown in the Mu et al. (1993) reproduced here (Fig. 18A). This structural configuration produced a relatively rigid internal strut system and lead the much less constrained connecting list to rotate outward to a more nearly horizontal orientation in flattened specimens, thus exaggerating the distinction between the portions of the dorsal thecal margin. The location of the diagonal list junction typically is located closer to the thecal aperture in more distal thecae but this also varies among corresponding theca in specimens that otherwise do not differ in size or shape. The type species $P r$. sinensis and O.denticulatus are identical in all other aspects of their dimensions and colony form as well as their stratigraphic and biogeographic distribution (see Table 12 and species descriptions below). Thus, we regard $O$. denticulatus as the junior synonym of $\mathrm{Pr}$. sinensis. 

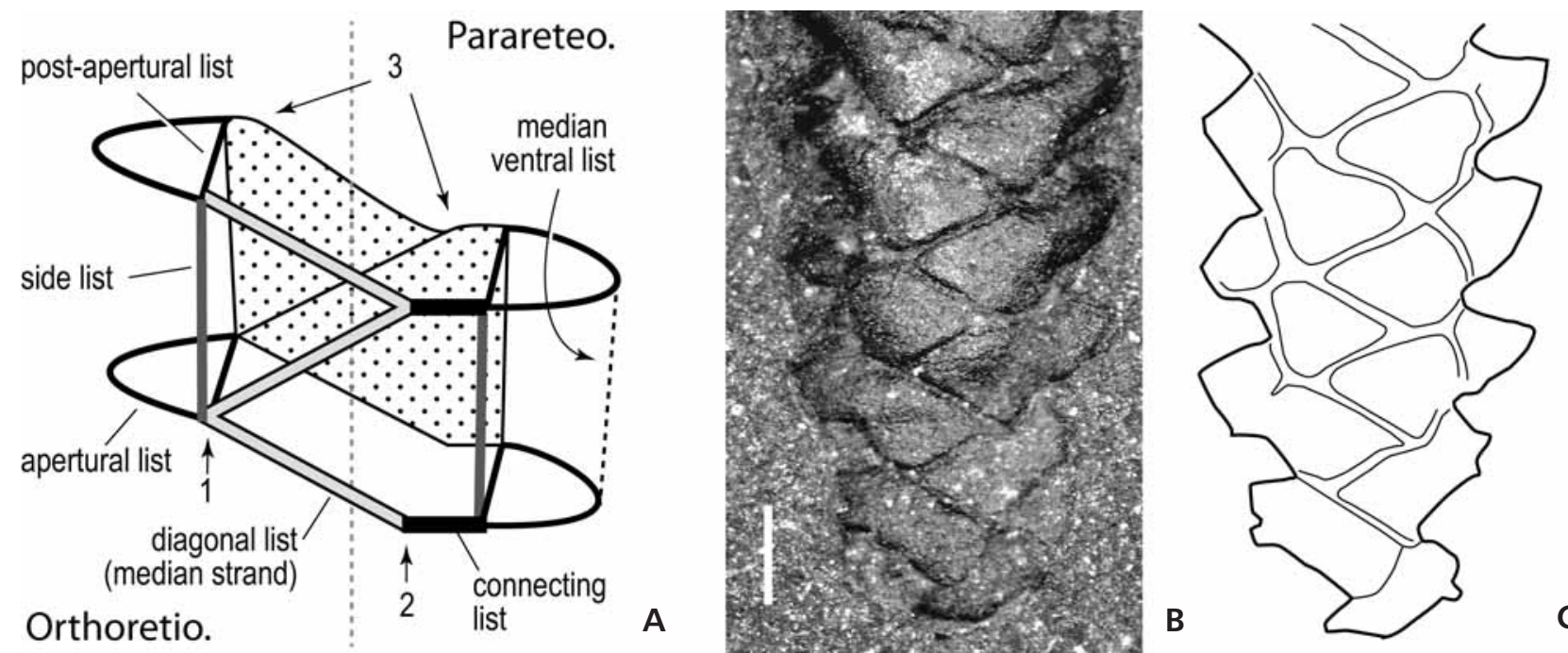

Figure 18. List structure of Parareteograptus. $\bullet$ A - schematic diagram showing the difference in list structure of distal thecae of Orthoretiograptus colonies (left side) and that of Parareteograptus colonies (right side) posited by Mu et al. (1993, text fig. 36c, d) but disputed herein. Arrow 1 points to direct connection between diagonal lists and the combined junction of the apertural list, side list and post-apertural list; arrow 2 points of presence of connecting list between diagonal list and apertural list junction; arrow 3 highlights continuity between diagonal and connecting list as arched dorsal list at leading edge of growing colony. Median ventral list (dashed) said to be present in Pseudoreteograptus. $\bullet$ B, C - Parareteograptus sinensis (NIGP 83257), proximal part of three-dimensionally preserved specimen from the Wufeng Shale (see also Mu et al. 1993, pl. 51, fig. 8); scale bar = 0.5 mm.

Finally Pseudoreteograptus (Mu, 1993), which was erected upon the greater degree of thecal wall reduction and presence of median ventral lists (Fig. 18A), also is regarded here as a junior synonym of Parareteograptus. These differences are entirely taphonomic and astogenetic in origin. Young Parareteograptus colonies generally have no or only a very thin sheet of material over the lists. The median ventral list, said to characterize this genus, appears to have been founded on a confusion with lateral lists of the opposite side rendered unusual in their appearance by oblique compression and incomplete preservation. The colony form and dimensions of Pr. nanus closely match those of Pr. turgidus, and we regard the former species as a junior synonym (based on page priority) of the latter (see Table 12 and species descriptions below).

"Retiograptus" pulcherrimus Keble \& Harris, 1934 appears to have a thecal framework very similar to that of Parareteograptus but has lateral apertural spines and an orthograptid-like proximal structure. It may be derived from a species such as Orthograptus eucharis Hall, 1865, which has strongly thinned colony walls and well developed lists (see Goldman \& Bergström 1997, pl. 3, text-fig. 15A-C). Mu et al. (1974) and Mu et al. (1993) also included Sinoretiograptus mirabilis $\mathrm{Mu}$ within their conception of the Retiograptidae together with Parareteograptus and Retiograptus. Si. mirabilis has a unique structure that is quite difficult to interpret from the available material but may be a highly derived descendant of Cryptograptus (see Vandenberg 2003), although it is very much younger than any other known representative of that clade.

\section{Parareteograptus sinensis Mu, 1974}

Figures 14B, I-K, S, T, 15A, E, F, H, K-M, Table 13

1963b Reteograptus grandis var. uniformis; Mu \& Zhang (in $\mathrm{Mu})$, p. 360, fig. 6 .

1974 Parareteograptus sinensis; Mu (in Nanjing Institute of Geology and Palaeontology ed.), pp. 163, 164, pl. 70, fig. 13.

1977 Retiograptus pulcherrimus Keble \& Harris. - Lenz, pp. 1950-1952, pl. 1, figs 3-7.

1978 Orthoretiograptus denticulatus gen. et sp. nov., Mu (MS). - Wang et al., p. 345, pl. 105, fig. 5.

1978 Parareteograptus regularis sp. nov. Mu (MS). Wang et al., pp. 346, 347, pl. 105, fig. 1.

1982 Orthoretiograptus denticulatus Wang et al., 1977. Williams, pp. 43, 44, pl. 4, figs 13-15; text-fig 12a, b.

1984 Pararetiograptus uniformis; Mu \& Lin, p. 64, pl. 8, fig. 4.

1984 Pararetiograptus sinensis Mu. - Mu \& Lin, p. 64, pl. 8, figs 7, 8 .

1993 Pararetiograptus sinensis $\mathrm{Mu} .-\mathrm{Mu}$ (in $\mathrm{Mu}$ et al.), pp. 227-229, pl. 51, figs 2-8; text-fig. 37a, b (see for further reference on $P$. sinensis).

1993 Pararetiograptus regularis $\mathrm{Mu}$. - Mu (in $\mathrm{Mu}$ et al.), pp. 229, 230, pl. 53, figs 1-8, 10, 11; text-fig. 37d.

1993 Orthoretiograptus denticulatus $\mathrm{Mu}$. - Mu (in $\mathrm{Mu}$ et al.), pp. 233, 234, text-fig. 39a, b (see for further reference on $O$. denticulatus).

Material and stratigraphical range. - Common species of the ornatus Zone and lower pacificus Zone at Vinini Creek 
Table 13. Parareteograptus sinensis. Dimensions of illustrated and other exemplary specimens (in mm).

\begin{tabular}{llllllllll}
\hline \multirow{2}{*}{ Specimen } & \multirow{2}{*}{ Text-figure } & \multicolumn{4}{c}{$\mathrm{W}$} & \multicolumn{5}{c}{ 2TRD } \\
\cline { 3 - 9 } & & th1 & th5 & th10 & dist. max & th2 & th5 & th10 & dist. th \\
\hline 542684 & $14 \mathrm{~B}, 15 \mathrm{~F}$ & 0.9 & 1.45 & 1.9 & - & 0.9 & 1.2 & - & - \\
542771 & $14 \mathrm{I}, 15 \mathrm{~L}$ & 0.9 & 1.7 & 2.3 & - & 0.95 & 1.35 & 1.55 & - \\
542763 & $14 \mathrm{~J}, 15 \mathrm{~K}$ & 0.95 & 1.55 & 2.15 & 2.9 & 0.85 & 1.2 & 1.5 & 1.85 \\
542687 & $14 \mathrm{~K}, 15 \mathrm{M}$ & 0.9 & 1.6 & 1.75 & $>2.3$ & 0.9 & 1.2 & 1.6 & - \\
542746 & $14 \mathrm{~S}$ & 1.05 & 1.7 & 2.0 & - & 0.9 & 1.3 & 1.45 & - \\
542858 & $14 \mathrm{~T}$ & 1.0 & 1.45 & 2.0 & - & 1.0 & 1.25 & 1.7 & - \\
542856 & $15 \mathrm{~A}$ & 0.9 & 1.6 & 2.15 & - & 0.95 & 1.35 & 1.85 & - \\
542714 & $15 \mathrm{E}$ & 0.8 & - & - & - & 0.93 & - & - & - \\
$542845 \mathrm{~b}$ & - & 0.9 & 1.5 & 2.05 & 2.55 & 1.05 & 1.4 & 1.7 & $\sim 2.0$ \\
\hline
\end{tabular}

Table 14. Parareteograptus turgidus. Dimensions of illustrated specimens (in mm).

\begin{tabular}{lllllllll}
\hline \multirow{2}{*}{ Specimen } & \multirow{2}{*}{ Text-figure } & \multicolumn{2}{c}{ W } & \multicolumn{7}{c}{ 2TRD } \\
\cline { 3 - 9 } & & th1 & th3 & th5 & th10 & th2 & th5 & th10 \\
\hline 542724 & $10 \mathrm{M}, 15 \mathrm{D}$ & 1.2 & $?$ & $>2.1$ & - & 1.0 & 1.25 & - \\
542695 & $10 \mathrm{P}, 15 \mathrm{C}$ & 1.3 & 2.2 & 2.4 & - & 0.95 & 1.2 & - \\
542852 & $10 \mathrm{U}, 15 \mathrm{~B}$ & 1.7 & 2.3 & - & 2.65 & 1.0 & 1.25 & 1.25 \\
542703 & $10 \mathrm{~W}$ & 1.2 & $?$ & 2.45 & $?$ & $?$ & $\sim 1.3$ & $?$ \\
\hline
\end{tabular}

and Martin Ridge. Several rhabdosomes, although not firmly assigned, came from the higher part of the pacificus Zone. Of more than 60 flattened rhabdosomes from limestones, mudstones and black shales, 27 were measured in detail.

Description. - Robust rhabdosome attains maximum length of almost $60 \mathrm{~mm}$, and maximum width of $2.95 \mathrm{~mm}$. Proximal end rounded, $0.8-1.0 \mathrm{~mm}$ wide at th $1^{2}, 1.2-1.7 \mathrm{~mm}$ at th5, and $1.7-2.3 \mathrm{~mm}$ at th10. Thereafter maximum width attained more gradually, well after th20. Sicula fully covered in reverse view. Sicular aperture bears horn-like virgella and two antivirgellar spines at corners of nearly straight dorsal margin. Lateral margin is hidden in $0.15-0.3 \mathrm{~mm}$ wide and deep semicircular excavation. Upon compression dorsal side of sicula tends to fold outward so that one antivirgellar spine projects nearly straight down (parallel to the virgella) and the other nearly horizontally, giving the appearance of a basal thecal spine on th $1^{2}$. Ascending part of th $1^{1}$ rounded, short and with conspicuous subapertural spine. Th $1^{2}$ turns outwards and upwards at or slightly below the sicular aperture. Some specimens also possess mesial spine on th $1^{2}$. Subsequent thecae have straight supragenicular walls inclined at $20-30^{\circ}$ (with extremes of $10^{\circ}$ and $40^{\circ}$ ). Regularly alternating, adpressed thecae with broad, slightly introverted apertures with lateral lappets. Fairly straight thecal tubes strengthened by apertural list and much thinner, rarely visible lateral lists. Apertural lists are interconnected by equally strong dorsal lists that form a prominent zigzag median strand on both obverse and reverse lateral walls of the rhabdosome. Slender nema is not incorporated in the thecal framework. Thecal walls continuous, thin in immature specimens and fairly well thickened in mature rhabdosomes. Thecae number 8 in $5 \mathrm{~mm}$ proximally $\left(2 \mathrm{TRD}_{2}: 0.8-1.3 \mathrm{~mm}, 2 \mathrm{TRD}_{5}: 1.2-1.45 \mathrm{~mm}\right)$, reducing to $14-9$ in $10 \mathrm{~mm}$ distally $\left(2 \mathrm{TRD}_{10}: 1.45-1.9 \mathrm{~mm}\right.$, $2 \mathrm{TRD}_{\text {dist }}: 1.75-2.4 \mathrm{~mm}$ ).

Remarks. - Mu \& Zhang (in Mu 1963b) named this taxon Reteograptus magnus var. uniformis, which $\mathrm{Mu} \& \mathrm{Lin}$ (1984) later transferred to Parareteograptus and raised to the species rank, although the name was not accompanied by valid description in $\mathrm{Mu}$ (1963b). Rather, it was mentioned only in connection with a general discussion about the form of the median septum (Mu 1963b, p. 359). Thus, according to Article 13 of the International Code of Zoological nomenclature (ICZN 1999), this name was not made available by that publication. Instead, the name was made available by Mu \& Lin (1984, p. 64) who state: [Pr. uniformis] "differs from Parareteograptus sinensis in the much longer rhabdosome." Thus, Pr. uniformis Mu \& Lin is a junior synonym of Pr. sinensis $\mathrm{Mu}, 1974$.

As noted above, dimensions, thecal shapes, and colony form in Pr. sinensis $\mathrm{Mu}$ are also comparable to those of $O$. denticulatus $\mathrm{Mu}$ and we treat the latter as a junior synonym of the former as well (Table 12). We agree with Chen et al. (2000) that Parareteograptus regularis also appears to be a junior synonym of this species. Finally, some of our 
specimens approach the dimensions of the holotype of Parareteograptus magnus $\mathrm{Mu}$ (Tables 12, 13). It appears to us that this taxon could also fall within this range of variation of Pr. sinensis and that the holotype of Pr. magnus may be only an unusually large individual, although this will require study of a larger population of specimens than is presently available to us.

\section{Parareteograptus turgidus $\mathrm{Mu}, 1993$}

Figures 10M, P, U, W, 15B-D, Table 14

1993 Pararetiograptus turgidus $\mathrm{Mu}$ (sp. nov.); $\mathrm{Mu}$ (in $\mathrm{Mu}$ et al.), pp. 230, 231, pl. 51, figs 9-12; text-fig. 37e.

1993 Pseudoreteograptus nanus $\mathrm{Mu}$ (gen. et sp. nov.); $\mathrm{Mu}$ et al., pp. 232, 362, 363, pl. 54, figs 1-3, text-fig. 38.

Material and stratigraphical range. - Seven flattened specimens - five complete and two fragmentary rhabdosomes - from black shale in the middle part of the pacificus Biozone of Vinini Creek section.

Description. - Almost $10 \mathrm{~mm}$ long rhabdosome exhibits particularly thin walls strengthened by well developed lists of thecal framework. Rhabdosome 1.3-1.7 mm wide across at the apertures of the first thecal pair, widens rapidly to $2.2-2.3 \mathrm{~mm}$ at th3, and $\sim 2.4 \mathrm{~mm}$ attained with th5. Maximum width of $2.65 \mathrm{~mm}$ observed at th10. Th1 ${ }^{1}$ and th $1^{2}$ metathecae relatively short $(0.8-0.85 \mathrm{~mm})$, former with short subapertural spine, grow more outwards than upwards and form rather blunt, dish-like shaped proximal end. Concave sicular aperture $0.35 \mathrm{~mm}$ wide (measured in one specimen) but mostly obscured by th $1^{2}$ crossing canal; minute virgella and short, stout antivirgellar spines, one of which typically appears upon compression to be a mesial spine on th $1^{2}$. Thecae are steeply inclined $\left(>45^{\circ}\right)$ and densely spaced; $2 \mathrm{TRD}_{2}: 0.95-1.0 \mathrm{~mm}, 2 \mathrm{TRD}_{5}: 1.2-1.3 \mathrm{~mm}$ and $2 \mathrm{TRD}_{10}: 1.25 \mathrm{~mm}$. Alternating thecae framed by strong apertural lists, post-apertural lists, and slightly inclined lateral (ventral) lists interconnected by prominent arched dorsal lists arranged in regular zigzag pattern developed equally in both lateral sides of the rhabdosome. Distance between two lateral strands: $1.1-1.35 \mathrm{~mm}$.

Remarks. - In contrast to Chen et al. (2000), we retain Parareteograptus turgidus $\mathrm{Mu}, 1993$ as a species distinct from Pr. sinensis Mu, 1974. Parareteograptus turgidus differs from Parareteograptus sinensis $\mathrm{Mu}$ in that the thecae exhibit much less increase in length distally and the rhabdosome widens much more quickly, achieving its maximum width by about th5. Pr. turgidus is as wide at th 3 as Pr. sinensis is at th10. Thecae are more steeply inclined in Pr. turgidus and lists of thecal framework, lateral lists in particular, are more massive. The distance between two la- teral strands is constant or slightly decreasing distally in Pr. turgidus. The holotype and paratypes of Pseudoreteograptus nanus $\mathrm{Mu}$ (in $\mathrm{Mu}$ et al., 1993) closely match those of Pr. turgidus. Thecae of the first pair are strongly extended outward, and the rhabdosome is $1.5 \mathrm{~mm}$ wide at that point. Widths increase rapidly to $2.3 \mathrm{~mm}$ at th 5 where it is maintained briefly and then declines to 2.1 at the distal end of the colony (th10). Thecal spacing is similarly high; 2TRD $2: 1.0 \mathrm{~mm}, 2 \mathrm{TRD}_{5}: 1.33 \mathrm{~mm}$, which is maintained thereafter and, as in Pr. turgidus, the thecal framework is very robust.

Blunt proximal end of $P$. turgidus with its ventrally growing metathecae of th $1^{1}$ and th $1^{2}$ and shallow sicular apertural excavation strongly resembles that of Parareteograptus parvus $(\mathrm{Mu})$, which is, however, a considerably smaller form. The distance between lateral strands is $1.4 \mathrm{~mm}$ at max width and declines to $2.1 \mathrm{~mm}$ distally. Consequently, we regard $P r$. nanus as a junior synonym of Pr. turgidus.

\section{Parareteograptus parvus (Mu, 1982)}

Figures 10L, 15G

1982 Parareteograptus parvus $\mathrm{Mu}(\mathrm{MS}) ; \mathrm{Mu}$ (in Fu et al.), p. 471, pl. 294, fig. 14.

1993 Pararetiograptus parvus Mu. - Mu et al., p. 231, pl. 52, fig. 9; pl. 53, figs 12 , 13, text-fig. 37 f.

Material and stratigraphical range. - Two minute rhabdosomes from the pacificus Zone of Vinini Creek section. Illustrated specimen originates from black shale at $10.30 \mathrm{~m}$.

Description. - Minute rhabdosome, with $1.25 \mathrm{~mm}$ wide proximal end and flat, dish-like profile of supragenicular ventral walls of th $1^{1}$ and th $1^{2}$. Sicular apertural excavation obscure. Rhabdosome gently widens to $1.4 \mathrm{~mm}$ at th 3 and $1.5 \mathrm{~mm}$ at th5. 2TRD $1.1 \mathrm{~mm}$ at th2 and $\sim 1.2 \mathrm{~mm}$ at th5. Steeply inclined thecae framed by apertural list and slightly inclined lateral lists. Pleural lists are negligible. Apertural lists of sub-alternate thecae interconnected by prominent dorsal lists that compose regular zigzag structure in both lateral sides of the rhabdosome. Thecal wall was either thin or missing.

Remarks. - Present rhabdosomes closely resemble specimens of Parareteograptus parvus described and figured by Mu et al. (1993) by their broad proximal end and nearly parallel sided rhabdosome with thecal walls reduced to prominent lists. Thecal spacing and rhabdosome width are equal or perhaps even a little smaller in the present material. Pr. parvus is distinguished from the other species of Parareteograptus by its comparatively small size, particularly by the slight widening. 
Family Lasiograptidae Lapworth, 1879; emend. Mitchell, 1987

Remarks. - Among the most characteristic features of the Late Ordovician lasiograptids [the Archiretiolitinae of Bulman (1955)] is the extensive development of the lacinia the three-dimensional mesh of extrathecal threads that developed from bifurcated spines located at the midline on the thecal aperture. These bifurcated spines are homologous with those on the pseudogeniculum in thecae of Lasiograptus and Neurograptus (Mitchell 1987, 1988). In addition, many of these graptolites exhibit "septal spines" or scopulae that arise from the nema and pass through the lateral wall of the colony. In some cases these take the form of simple spines (e.g., Orthoretiolites hami, Yinograptus disjunctus) and in other cases they form membrane-bearing bifurcated spines and paddle-like extensions (Hallograptus mucronatus, Neurograptus fibratus), gorgonian-like fan systems (Nymphograptus vellatus), or a complex network that connects with the lacinia from the thecal margins, fully enmeshing the colony (Phormograptus). Finally, the fusellar walls of the thecae are reduced to a framework of lists, in some cases accompanied by a reticulum-like mesh between the lists, and so replaces the fusellar thecal walls of more primitive lasiograptids. In contrast, the retiolite-type features of the Retiolitidae (Neograptina) are based on a radically different structure (see Bates et al. 2005 for a recent review) that evolved entirely independently of the lasiograptids (Mitchell 1987). The main reticulate frame and associated mesh of threads that form the rhabdosome in the Retiolitidae were formed as elaborations of the ancora, which is a unique umbrella-like modification of the virgella (see Bulman 1970, fig. 59) that first appeared among petalolithids. In some primitive members of the group (e.g., Pseudorthograptus obuti, Koren' \& Rickards 1996, text-fig. 15) the ancora grew upward and surrounded the proximal part of the colony in a manner that is superficially similar to the set of threads that form the lacinia in lasiograptids. In fully retiolitid graptolites this structure, the now much expanded ancora sleeve, fully enclosed and became intermeshed with the highly reduced thecal frame. In many of the Retiolitidae the ancora sleeve forms a variously dense, more-or-less twodimensional mesh that is called a reticulum. This mesh gives the appearance of being the lateral walls of the thecae, but is actually extrathecal in origin and, thus, has a quite different relationship to the colony structure than the lasiograptid thecal reticulum.

Genera of the retiolite-type lasiograptids differ from one another in the development of the lacinia, the geometry of the thecal framework and in the presence or absence of reticulum. Too few species are known in sufficient detail to construct a detailed phylogeny for this group. Phormograptus sooneri, Yinograptus disjunctus, and Paraplegmatograptus uniformis form a trichotomy in the available analyses (e.g., Mitchell et al. 2007b; see fig. 1). Thus, we employ character-based definitions here.

Mu (e.g., Mu \& Lin 1984, Mu et al. 1993) included two distinctly different groups of species within the genus Paraplegmatograptus. The first of these, the 'uniformis' group, includes the type species, which has a well-developed lacinia that surrounds the sicular aperture but is confined to the apertural margins (as in Lasiograptus and Neurograptus) in mature parts of the colony (Fig. 16Q; Mu et al. 1993, pl. 53, fig. 9; pl. 55, figs 6, 7). The thecal frame consists of 1) a distinct set of apertural rings (apertural list plus post-apertural lists), 2) a set of lateral lists that form scalloped lateral strands, and 3) a very irregular set of zigzag dorsal lists that are evident only in juvenile thecae because they quickly become obscured by a variously dense reticulum that develops in the place of the normal thecal walls (e.g., Fig. 16Q; Mu et al. 1993, pl. 65, fig. 4). In addition to their origin from median apertural spines, the lacinia is typically connected to the lateral lists at many sites but particularly by a thickened regular set of lacinial threads located more or less mid way between successive apertures. This feature may obscure the location of thecal apertures. The nema appears to be entirely free within the rhabdosome over most of its length. Yinograptus Mu has a very similar structure but in this group the reticulum is much less complex and the nema is linked to the thecal frame (contra Mu et al. 1993, pp. 249 and 367) by long, robust, septal spines that generally project well beyond the thecal framework at every fourth theca.

Figure 19. A - Anticostia macgregorae Stewart \& Mitchell, 1997: USNM 542720, scree. • B, K, N, P - Anticostia fastigata (Davies, 1929): B - USNM 542686, level 7.65 m; K - USNM 542677, level 7.50 m; N - USNM 542722, scree; P - USNM 542811, level 17.80 m. • C, D, L - Anticostia uniformis (Mu \& Lin, 1993): C - USNM 542812, level 17.80 m; D - USNM 542716, level 18.30 m; L - USNM 542672, level 16.00 m. • E-G, Q, R - Anticostia tenuissima (Ross \& Berry, 1963): E - USNM 542755a, level MR 96.13 m; F - USNM 542755b, level MR 96.13 m; G - USNM 542855, level MR 96.13 m; Q - USNM 542761, level MR 96.13 m; R - USNM 542853, level MR 96.13 m. • H-J, M, O, T - Anticostia lata (Elles \& Wood, 1906): H - USNM 542744, level MR 90.20 m; I - USNM 542682, level 7.65 m; J - USNM 542727, level 7.65 m; M - USNM 542668, level 1.55 m; O - USNM 542850, level 14.15 m; T - USNM 542681, level 14.15 m. • S - Anticostia thorsteinssoni Melchin, 1987: USNM 542669, level 1.55 m. • USNM 542668, 542669, 542677, 542682, 542686, 542727, 542744, 542755a, 542755b, 542761, 542853 and 542855 from the ornatus Biozone and USNM 542672, $542681,542716,542720,542722,542811,542812$ and 542850 from the pacificus Biozone. USNM 542668, 542669, 542672, 542677, 542681, 542682, 542686, 542716, 542720, 542722, 542727, 542811, 542812 and 542850 from the Vinini Creek section, USNM 542744, 542755a, 542755b, 542761, 542853 and 542855 from the Martin Ridge section. All figures $\times 6$ (common scale bar equals $1 \mathrm{~mm}$ ), except B $\times 3$ (assigned scale bar equals $1 \mathrm{~mm}$ ). 
Petr Štorch et al. • Uppermost Ordovician graptolites of north-central Nevada
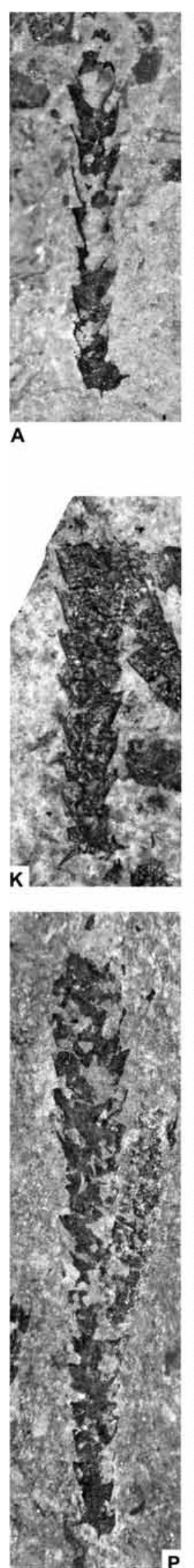

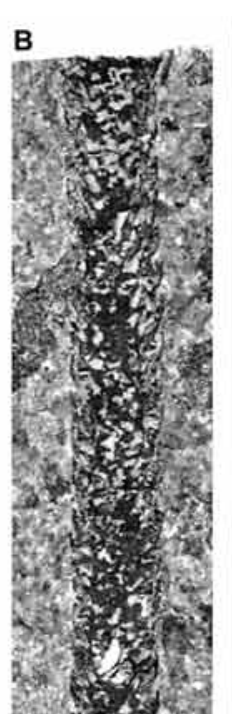

Qnisitis:

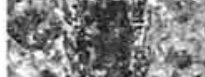

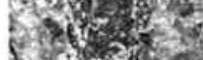

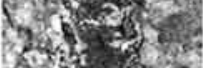
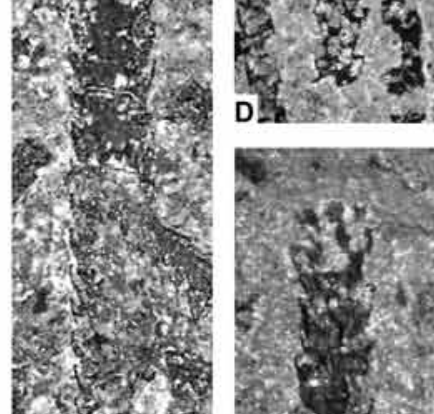

19.
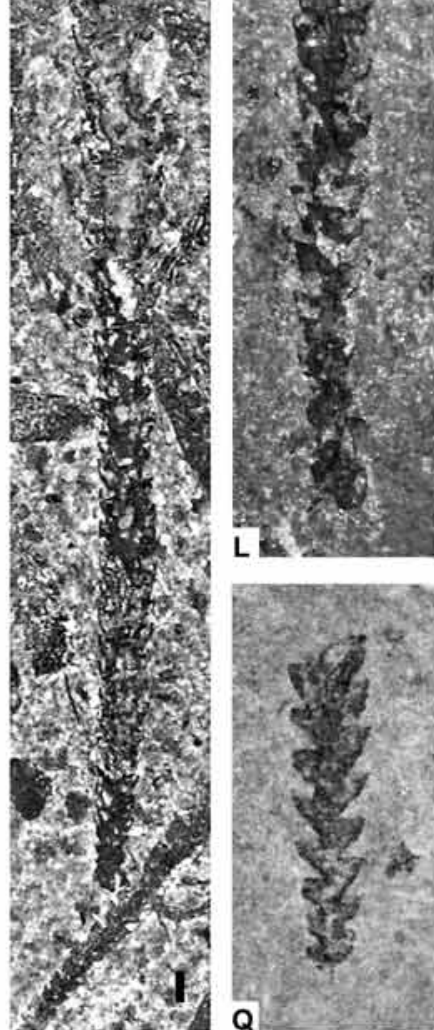
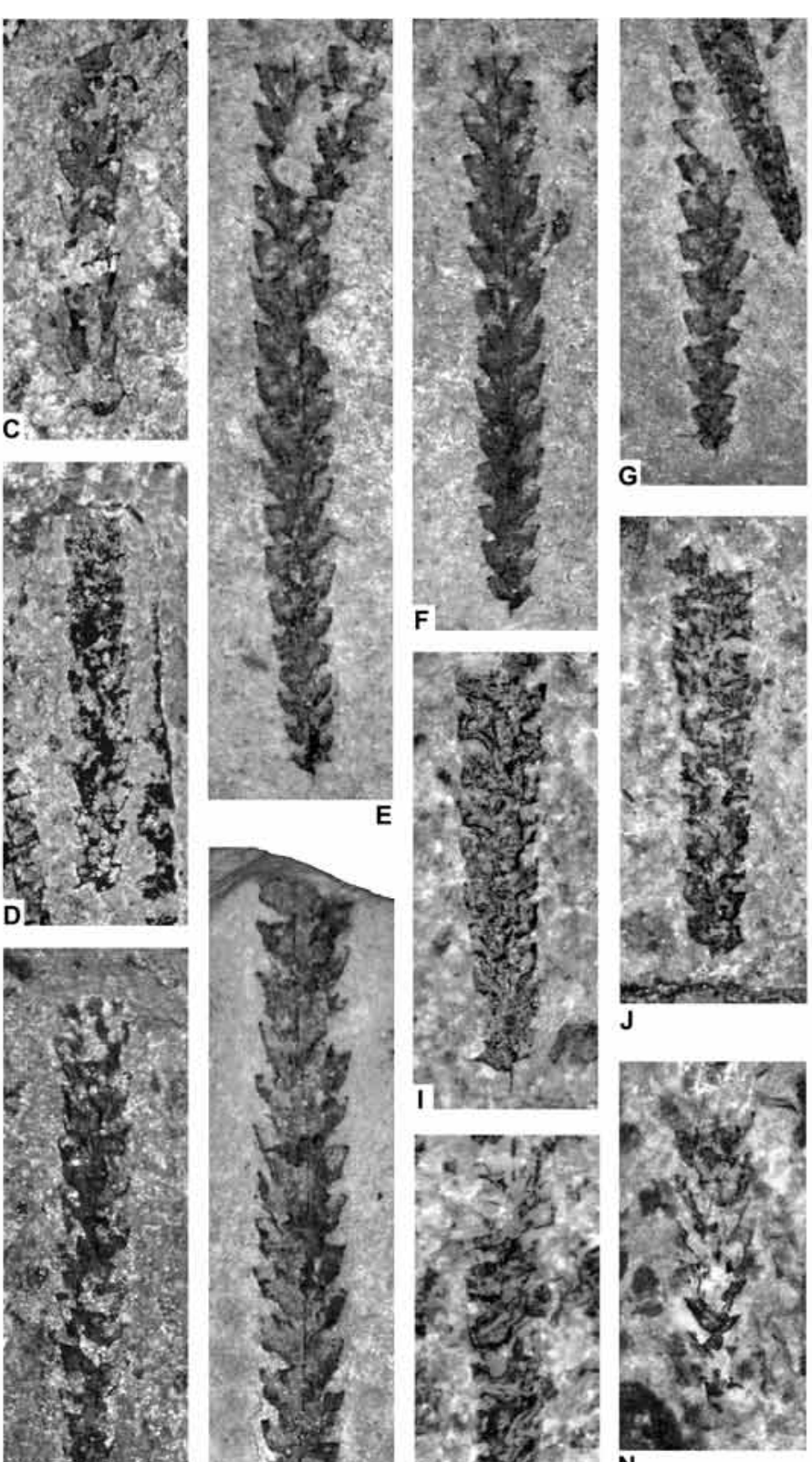

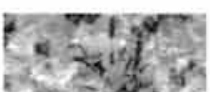

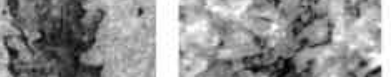

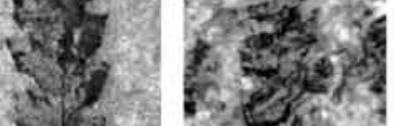

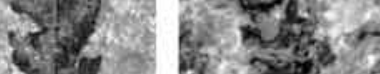

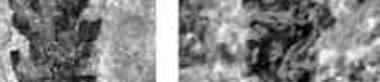

l. as 252

tis $18 \%$
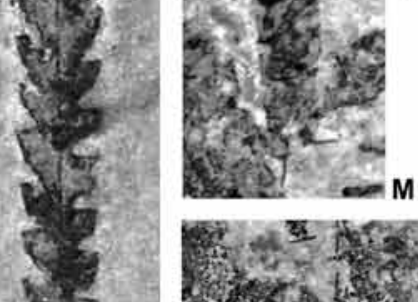

1. 3

50
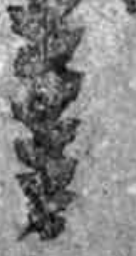

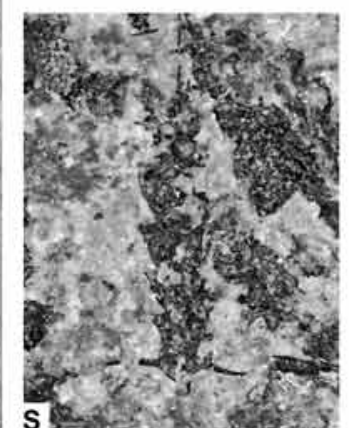

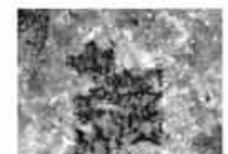
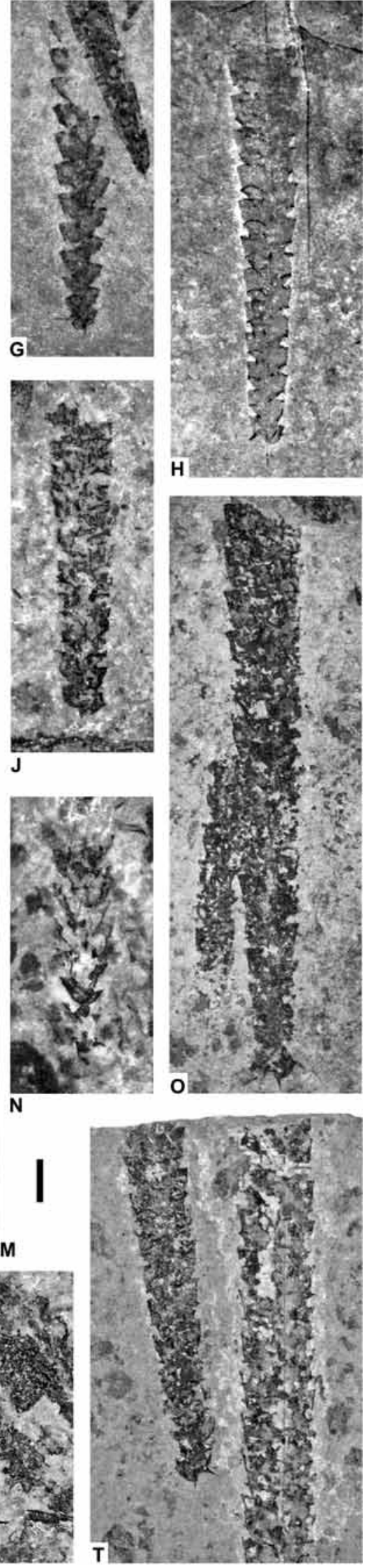
The other set of species, the "connectus" and "sextans" group species, on the other hand, are representatives of Phormograptus Whittington, 1955 (see Bates \& Kirk 1991, who redescribed $P h$. sooneri Whittington from a much larger set of uncompressed, isolated specimens than was available to Whittington). In Phormograptus the lacinia entirely surrounds the rhabdosome - both the apertural and lateral regions as well as around the sicular end of the colony. The lacinia has regular figure- 8 like openings along the thecal margin ( $c f$. Bates \& Kirk 1991, fig. 188, pl. 10; Mu \& Lin 1984, pl. 7, fig. 1 and Mu et al. 1993, pl. 58, figs 1, 2) and forms a deep three-dimensional mesh over the obverse and reverse sides of the colony. Again there are scopular spines that project outward from the nema and as well as additional radial spines that arise from the thecal frame (Bates \& Kirk 1991, fig. 161, pl. 11). The thecal frame, in contrast, is highly reduced. In the first pair, the thecae consist of a median ventral list and an apertural loop but in subsequent thecae, it consists solely of long arched dorsal lists that link to deep and narrow triangular apertures formed by a V-shaped apertural list (which gives rise to a bifurcated median spine and thence to the lacinia) and a short, straight post-apertural list (see Bates \& Kirk 1991, fig. 142, pls 11, 12). Lateral lists are absent throughout. The density of the lateral lacinial mesh and the reduced character of the thecal frame (dorsal lists are generally quite thin) make it extremely difficult to locate the thecae other than by the regularity of the spine bases where the lacinia attach to the thecal apertures and the associated figure 8-like apertures in the lacinia. It was this lack of clear differentiation between the thecal framework and lacinia that lead Ross \& Berry (1963) to propose the genus Arachniograptus for specimens of this group in the late Katian strata of the Phi Kappa Formation, but they misinterpreted the dense lacinial mesh of these specimens as an irregular thecal frame and reticulum. Inspection of the types reveals it to be a junior synonym of Phormograptus preserved in clingfilm mode (see Jones et al. 2002).

Additionally, the deep lacinia commonly leads to preservation of specimens of these species in scalariform view. In this aspect the apertural openings of the lacinia may be more evident and the scopulae and other projecting spines radiate from the nema beyond the globular specimens and, here again, thecae are very difficult to discern (e.g., Fig. 16B; Mu et al. 1993, fig. 47b, pl. 62, figs 3, 5). Specimens in profile and scalariform view may differ substantially in appearance and dimensions. Taphonomic effects induced by splitting through a specimen that was filled with sediment prior to compaction versus those with more complex superimposition of the full form without sediment infill through clingfilm preservation (Jones et al. 2002), also complicate comparison but provide clues about the three-dimensionality of the structure.
Phormograptus differs from Plegmatograptus, which also has a fully enclosing lacinia, by the fact that the latter retains a better defined thecal frame that includes lateral lists and a reticulum (similar in form and complexity to those of Paraplegmatograptus), and often with a covering sheet of material. Thus, Phormograptus and Plegmatograptus differ mainly in the details of the thecal frame whereas Paraplegmatograptus and Plegmatograptus differ mainly in the development of the lacinia and perhaps in the somewhat more fully thickened thecal walls of the latter.

\section{Genus Paraplegmatograptus Mu, 1963b}

Type species. - Paraplegmatograptus uniformis $\mathrm{Mu}$ (in Wang et al., 1978; p. 210, pl. 51, figs 1,2); subsequently designated by Mu \& Lin 1984, p. 66.

Definition. - Derived lasiograptids with obverse and reverse walls reduced to irregular clathrium consisting of lateral lists, indistinct dorsal lists and well defined planar reticulum combined with prominent lacinia that surrounds sicular aperture and is confined to apertural margins of colony.

Species included. - Paraplegmatograptus uniformis $\mathrm{Mu}$ (in Wang et al., 1978), Pp. delicatulus Mu \& Lin, 1984; Pp. dubius $\mathrm{Mu} \&$ Lin, 1984; Pp. hongyanxiensis $\mathrm{Fu}, 1982$; Pp. magnus Wang (in Wang et al. 1978).

Remarks. - The nomenclatural history of this genus is complex. Mu first referred to Paraplegmatograptus in a paper devoted to graptolites from Chilianshan (Mu 1963b), where he gave a brief description and stated that his conception of the genus was based on his studies of the Wufeng Formation faunas. He also mentioned that a representative of the genus, Paraplegmatograptus delicatulus $\mathrm{Mu}$ \& Zhang (in Mu, 1963b), occurs in the Chilianshan region. Although Mu illustrated that species (by a single immature specimen) he did not describe it, thus according to article 13 of the Code of Zoological Nomenclature (ICZN 1999), the name was not made available by that publication. The name Paraplegmatograptus uniformis was first made available by Wang et al. (attributed to $\mathrm{Mu}$ in Stratigraphy Research Group of the Yangtze Gorges, Hubei Bureau of Geology ed. 1978). Although Wang et al. (1978) described this and three other species that they placed within Paraplegmatograptus, they did not describe the genus itself or identify its type species. The genus was first fully described in Mu \& Lin (1984), at which time they proposed a new species, $P p$. dubius Mu \& Lin, redescribed Pp. uniformis, and $P p$. connectus, and gave a proper description for Pp. delicatulus, this time illustrated by Wufeng Formation mate- 
rial. This name, therefore was made available at that time and its authors are Mu \& Lin (1984), not Mu \& Zhang (in $\mathrm{Mu}$ 1963b). Mu \& Lin (1984) also explicitly selected Pp. uniformis as the type species of the genus. Thus, $P p$. uniformis is both the senior name and is validly established as the type of the genus.

\section{Paraplegmatograptus uniformis $\mathrm{Mu}$ \\ in Wang et al., 1978}

Figures 16A, C, Q, 20F, L, M

1978 Paraplegmatograptus uniformis Mu. - Wang et al. (in Stratigraphy Research Group of the Yangtze Gorges, Hubei Bureau of Geology ed.), p. 210, pl. 51, figs 1,2 (non pl. 50, fig. 12).

1978 Paraplegmatograptus gracilis Mu. - Wang et al. (in Stratigraphy Research Group of the Yangtze Gorges, Hubei Bureau of Geology ed.), p. 209, pl. 51, fig. 11.

1982 Plegmatograptus? craticulus sp. nov.; Williams, pp. 44, 45 (partim), text-fig.13a, h-k; non text-fig. 13g (text-fig. 13b-f, 1, uncertain).

1983 Paraplegmatograptus uniformis Mu. - Wang et al., pl. 4 , fig. 3.

1983 Paraplegmatograptus gracilis Mu. - Wang et al., pl. 3, fig. 10, pl. 11, fig. 4.

1984 Paraplegmatograptus uniformis Mu. - Mu \& Lin, pp. 65,66 , pl. 7 , fig. 3 .

1984 Paraplegmatograptus uniformis Mu. - Li, p. 502, pl. 192, fig. 14.

1993 Paraplegmatograptus uniformis $\mathrm{Mu}$ - Mu (in $\mathrm{Mu}$ et al.), pp. 240, 241; pl. 53, fig. 9; pl. 55, figs 5-7; pl. 56, figs 1,2 ; text-fig. 44 a-c.

1993 Paraplegmatograptus gracilis $\mathrm{Mu}$. - Mu (in $\mathrm{Mu}$ et al.), pp. 241, pl. 56, figs 3-8; text-fig. 45a-c.

1993 Paraplegmatograptus formosus $\mathrm{Mu}$ - Mu (in Mu et al.), pp. 241, 242, pl. 57, figs 1-4; pl. 59, fig. 7; pl. 60, fig. 1 ; text-fig. $46 \mathrm{a}-\mathrm{c}$.

Material and stratigraphical range. - Rare finds came from both ornatus Zone and pacificus Zone at Vinini Creek and Martin Ridge. 10 flattened rhabdosomes at our disposal are preserved in lime mudstones, mudstones and black shales.

Description. - Rhabdosome attains maximum length of $>22 \mathrm{~mm}$, possesses sac-like proximal end formed by lacinia that surrounds sicular end of colony and nearly parallel-sided distal part. Sicula not evident in our specimens. The nema free, not incorporated into the thecal framework. Early thecae and also sicular spines became enmeshed in delicate lacinia. Distal thecal framework somewhat irregular, composed of moderately arched dorsal-parietal lists arranged in irregular zigzag pattern and strengthened by reticulum composed of tetragonal to hexagonal meshes. Measured across lateral lists (excluding protruding, roughly horizontal, apertural lists and lacinia) rhabdosome widens from $1.1-1.3 \mathrm{~mm}$ at th $1,1.8-2.2 \mathrm{~mm}$ at th5, $1.8-2.4 \mathrm{~mm}$ at $8^{\text {th }}-9^{\text {th }}$ thecal pair, to max. observed: $2.9 \mathrm{~mm}$. 2TRD $51.8-2.2 \mathrm{~mm}$ and $2.0-2.4 \mathrm{~mm}$ at distal thecae. Sub-alternating thecal apertures consist of rather robust apertural, post-apertural, and pleural lists that can be readily distinguished from slender lacinia that do not enclose the lateral walls of the rhabdosome. Lacinia arose from thecal apertures and lateral spines attached to lateral lists between apertures. Including lacinia, rhabdosomes are 3.4-5.2 mm wide distally.

Remarks. - The colony form of this graptolite varies substantially as a function of colony maturity. This range of variation in form accounts for the several taxa that have been named based on specimens that most likely belong to this species. In addition to the synonyms Pp. gracilis and $P p$. formosus, it appears likely that specimens assigned to Pp. delicatulus Mu \& Lin, 1984 by these authors and Mu et al. (1993) may be young colonies of Pp. uniformis. Small colonies and the distal ends of larger colonies have relatively thin clathria and a delicate reticulum in which lists can generally be discerned. More mature parts of colonies become heavily thickened and the reticulum modified so that discrete panels corresponding to individual thecae are difficult to make out. The lacinia similarly shows extensive development as the colonies age and the regular threads that link the lacinia to the lateral lists between thecal apertures often become so thickened that they are difficult to distinguish from the thecal apertures. Wufeng Formation material examined by the authors suggests that the proximal development of this species appears to be similar to that of specimens referred to as "Phormograptus sooneri type A" by Bates \& Kirk (1991), in which the descending part of th $1^{1}$ is still present but the metatheca is represented by a short single median ventral list and an apertural loop that is connected to the descending protheca (e.g., Bates \& Kirk 1991, figs 114,121$)$. In addition, th $1^{2}$ consists of a ventral median list and triangular apertural list that is attached to the upper part of the sicula. This structure differs from that of the type material of Phormograptus sooneri Whittington $(1955 ;=P h$. sooneri type B of Bates \& Kirk 1991), in which the ventral median list of both th $1^{1}$ and th $1^{2}$ is longer than in the Ph. sooneri type A proximal structure and the apertural loops are not attached to the sicula.

\section{Genus Phormograptus Whittington, 1955}

Type species. - Phormograptus sooneri Whittington, 1955; pp. 847-850, pl. 83, figs 4, 5; text-figs 15-19; by original designation. 
Definition. - Species of the Lasiograptidae with highly reduced thecal framework consisting of lightly thickened dorsal lists, apertural lists and aboral lists. Dorsal lists linked to nema by scopular spines. Ventral lists absent. Lacinia encloses entire rhabdosome forming a complex, and often dense, three-dimensional mesh along obverse and reverse side of the colony and with regular apertural openings along the pleural margin of the colony.

Species included. - Phormograptus sooneri Whittington, 1955; Plegmatograptus? chuchlensis Přibyl, 1949; Arachniograptus laqueus Ross \& Berry, 1963; Paraplegmatograptus connectus $\mathrm{Mu}$ (in Wang et al,. 1978), Phormograptus? sinensis $\mathrm{Mu}$ (in Wang et al., 1978).

Remarks. - See discussion above under Lasiograptidae.

\section{Phormograptus connectus (Mu in Wang et al., 1978)} Figures 16B, E, F, 20B-E, H, K, Table 15

1978 Paraplegmatograptus hubeiensis Mu; Wang et al. (in Stratigraphy Research Group of the Yangtze Gorges, Hubei Bureau of Geology ed.), p. 209, pl. 51, fig. 9.

1978 Paraplegmatograptus connectus $\mathrm{Mu}$; Wang et al. (in Stratigraphy Research Group of the Yangtze Gorges, Hubei Bureau of Geology ed.), p. 209, pl. 51, figs 3, 4.

1982 Plegmatograptus? craticulus sp. nov.; Williams, pp. 44, 45 (partim), text fig. 13g; non text-fig. 13a, h-k (text-fig. 13b-f, 1, uncertain).

1984 Paraplegmatograptus connectus; Mu (in Mu \& Lin), p. 66, pl. 7, figs 1, 2 .

1993 Phormograptus connectus (Wang). - Mu (in $\mathrm{Mu}$ et al.), p. 237, pl. 54, figs 4-6, text-fig. 41.

1993 Paraplegmatograptus connectus $\mathrm{Mu}$ - - Mu (in Mu et al.), pp. 243, 244, pl. 57, figs 5, 6, 8; pl. 58, figs 1-3; pl. 60, fig. 2; pl. 61, figs $1-4$; text-fig. $47 \mathrm{a}-\mathrm{b}$.

1993 Paraplegmatograptus hubeiensis $(\mathrm{Mu}) .-\mathrm{Mu}$ (in $\mathrm{Mu}$ et al.), p. 245, pl. 54, figs 7, 9; pl. 55, figs 1-3; text-fig. 48a-c.

1993 Paraplegmatograptus sextans; Mu, p. 246, text-fig. 49a, b.

1993 Paraplegmatograptus connectus ovalis $\mathrm{Mu}$ - - Mu (in Mu et al.), p. 244, pl. 58, figs 4, 5; pl. 60, figs 3-5; pl. 62 , figs 1-6; text-fig. $47 \mathrm{c}$. 2005a Paraplegmatograptus connectus Mu. - Chen et al., pp. 246, 247, text-fig. 5F, CC.

Material and stratigraphical range. - Twenty-eight flattened rhabdosomes from suitable lime-mudstone, mudstone and black shale lithologies of the ornatus and pacificus zones of the Vinini Creek and Martin Ridge sections. Three specimens are from extraordinarius Zone of the Vinini Creek section. Finds were limited by the delicate structure of rhabdosomes rather then actual rarity of the species. Several fragments from the persculptus Biozone of Vinini Creek section were assigned to this species with reservation.

Description. - Specimens 8-12 mm (max. 19 mm) long, commonly flattened in biscalariform or subscalariform orientation, reflecting sub-circular cross section of the rhabdosome produced by fact that lacinia encapsulated the whole thecal framework. In the scalariform view the rhabdosome outline is roughly ellipsoid; rhabdosome width (measured across lacinia) increases rapidly from $1.0-1.45 \mathrm{~mm}$ at th1 to $4.1-5.1 \mathrm{~mm}$ at th5, and maximum width of 4.75-5.35 $\mathrm{mm}$ at th5-6. Proximal end appears somewhat protracted in scalariform view. Sicula $<1 \mathrm{~mm}$ long and fully developed (though not commonly visible). A prominent virgella extends $1.1-1.5 \mathrm{~mm}$ down the rhabdosome meshwork and paired antivirgellar spines also commonly prominent in scalariform view. Lacinial apertures of rectangular shape furnished with lateral spines that extend beyond dense portion of lacinia. Lacinia forms deep mesh that in mature specimens and portions surrounding lateral surfaces of rhabdosome often become very densely reticulate and obscures thecal framework due to similar thickness of these structures. 2TRD $1.65-2.1 \mathrm{~mm}$ at th5 and 2.0-2.3 $\mathrm{mm}$ in distal thecae of mature rhabdosomes. Central nema connected with the thecal framework by robust crossbars (scopulae) that continue as spines into lacinia and beyond. Laterally flattened (profile view) specimens exhibit less protracted, $1.5-1.6 \mathrm{~mm}$ wide proximal end that widens to a maximum of $3.4-5.1 \mathrm{~mm}$ including lacinia, whereas interior, interthecal, width ranges from 2.0 to $2.7 \mathrm{~mm}$. Recognizable clathrial framework shows steep inclination of the thecae.

Remarks. - Phormograptus connectus offers a particularly wide array of appearances depending on taphonomic

Figure 20. A, I, J - Yinograptus disjunctus Yin \& Mu, 1945: A - USNM 542800, level 10.30 m; I - USNM 542767, level MR 105.2 m; J - USNM 542783, level 3.00 m. • B-E, H, K - Phormograptus connectus (Mu, 1984): B - USNM 542790, level 4.00 m; C - USNM 542663, level 4.40 m; D - USNM 542730, level 4.40 m; E - USNM 542742, level MR $95.00 \mathrm{~m} ; \mathrm{H}$ - USNM 542784, level $4.40 \mathrm{~m}$; K - USNM 542750, scree. • F, L, M-Paraplegmatograptus uniformis Mu, 1978: F- USNM 542766, level MR 105.2 m; L - USNM 542799, level 10.30 m; M - USNM 542769, level MR $105.2 \mathrm{~m} . \cdot \mathrm{G}-$ Phormograptus sp.: USNM 542711, level $8.80 \mathrm{~m}$. USNM 542663, 542730, 542742, 542783, 542784 and 542790 from the ornatus Biozone, USNM 542711, 542750, 542766, 542767, 542769, 542799 and 542800 from the pacificus Biozone. USNM 542663, 542711, 542730, 542799, 542783, 542784, 542790 and 542800 from the Vinini Creek section, USNM 542742, 542750, 542766, 542767 and 542769 from the Martin Ridge section. All figures $\times 6$. Scale bar equals $1 \mathrm{~mm}$. 


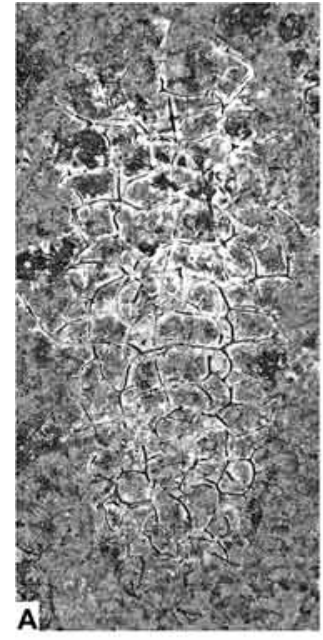

5.

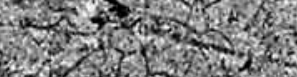

S.

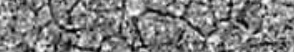

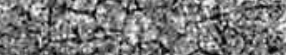

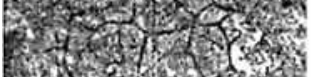

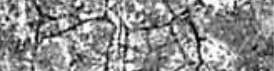

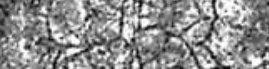
(3)

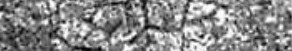
(1)

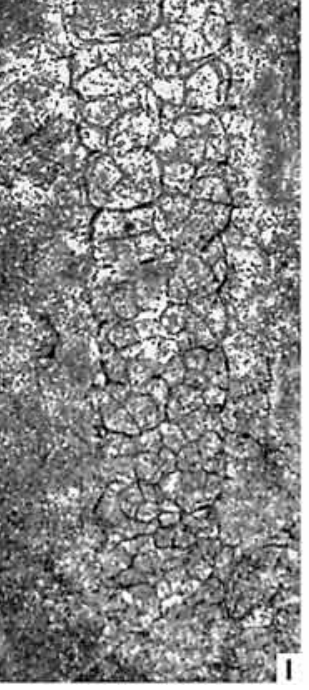

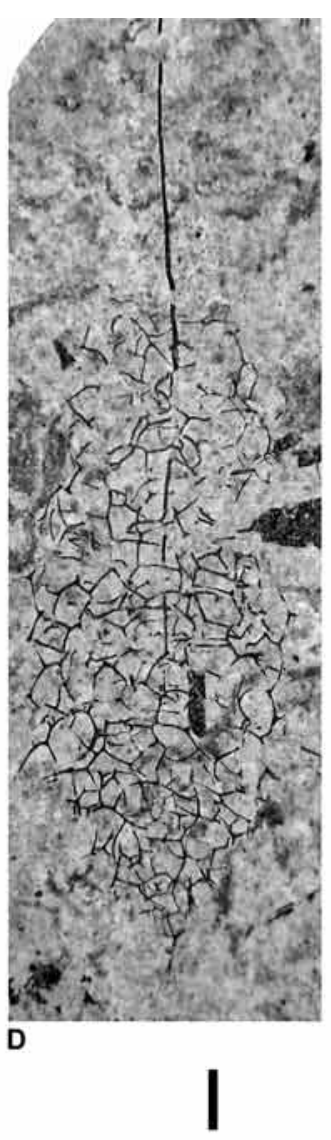
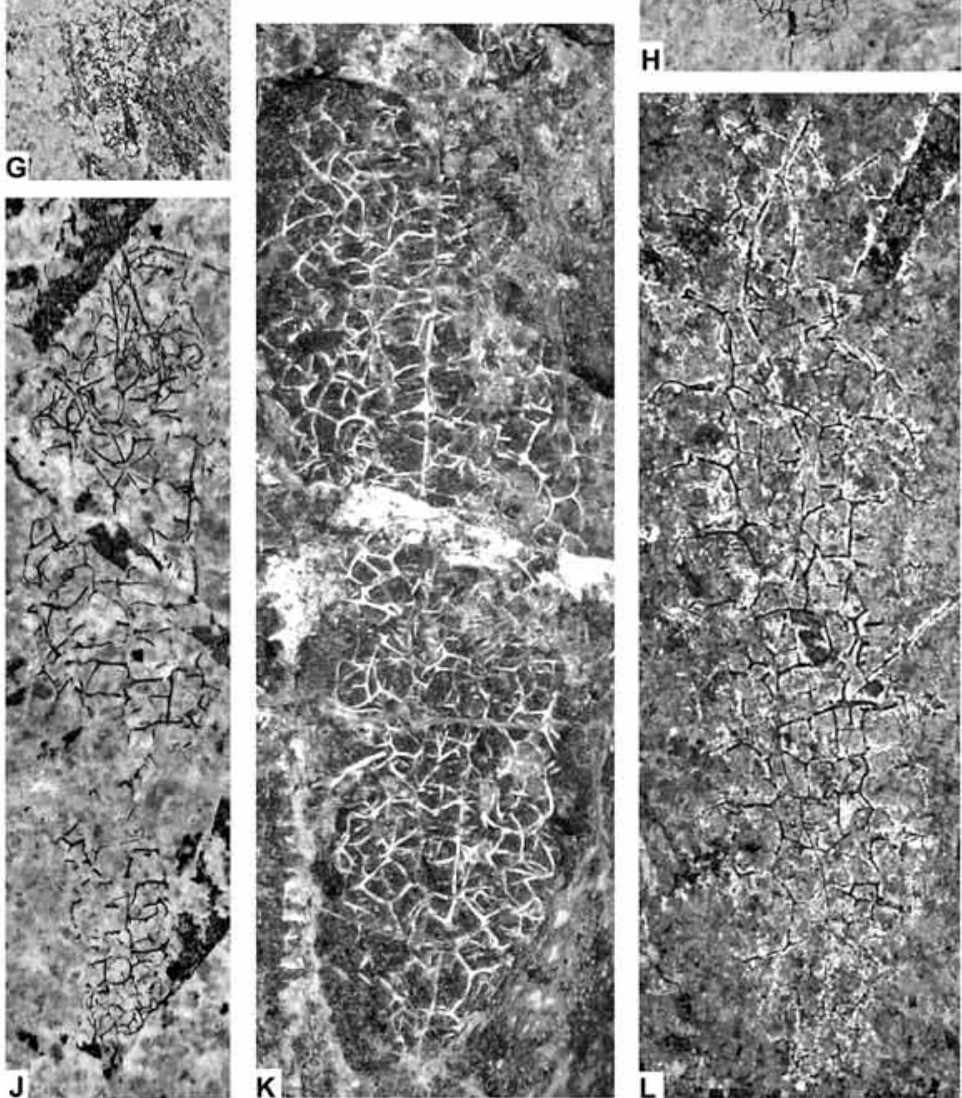
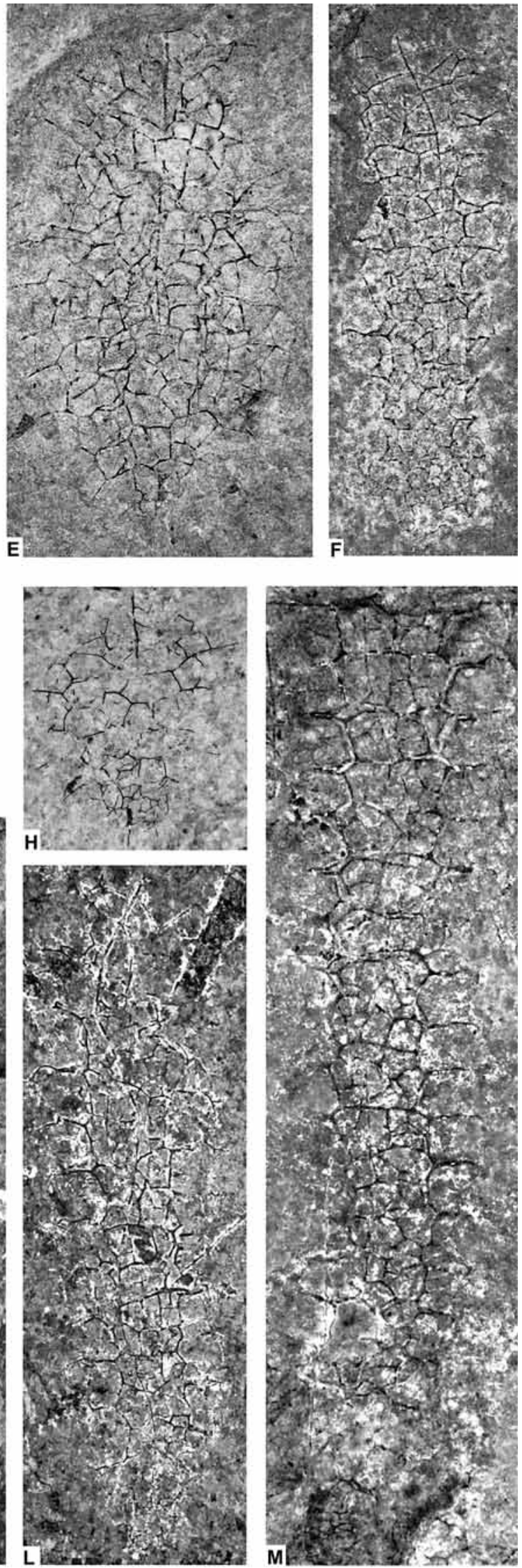
Table 15. Phormograptus connectus. Dimensions of illustrated and exemplary specimens (in mm).

\begin{tabular}{|c|c|c|c|c|c|c|c|c|}
\hline \multirow{2}{*}{ Specimen USNM } & \multirow{2}{*}{ Text-figure } & \multirow{2}{*}{ View } & \multicolumn{4}{|c|}{ W } & \multicolumn{2}{|c|}{ 2TRD } \\
\hline & & & th1 & th5 & $\max$ & max excl. lacinia & th5 & dist. th \\
\hline 542742 & $16 \mathrm{~B}$ & biscalariform & - & 5.1 & 5.35 & $?$ & 1.9 & 2.0 \\
\hline 542848 & $16 \mathrm{E}$ & lateral & 1.6 & 3.8 & - & 2.0 & 1.65 & - \\
\hline 542709 & $16 \mathrm{~F}$ & lateral & - & 4.7 & - & 2.7 & 1.85 & - \\
\hline 542790 & $20 \mathrm{~B}$ & scalariform & 1.3 & $?$ & - & - & 1.7 & - \\
\hline 542730 & $20 \mathrm{D}$ & lateral & - & 4.25 & 4.75 & $?$ & 1.8 & 2.1 \\
\hline 542784 & $20 \mathrm{H}$ & biscalariform & 1.45 & 4.1 & - & $?$ & 1.7 & - \\
\hline 542750 & $20 \mathrm{~K}$ & lateral & - & - & 5.3 & - & 1.9 & 2.3 \\
\hline 542827 & - & scalariform & - & 4.25 & - & $?$ & 1.65 & - \\
\hline
\end{tabular}

effects, state of maturity of the colony, and the orientation of specimens on the slab (profile, biscalariform or fully scalariform). Additionally, the character of the lacinia is quite different along the apertural margins of the colony (where it contains large polygonal apertural openings) than it is over the obverse and reverse sides of the colony (where it forms a densely reticulate mesh). The lightly thickened and highly simplified thecal frame is deeply hidden within this complex pleural lacinia. The complexity of the pleural lacinia in particular increased substantially as the colony matured but also appears to depend on taphonomic features. In cases where the colony was strongly flattened in profile with little internal sediment (clingfilm preservation of Jones et al. 2002) the full complexity of the pleural lacinia is pressed over the colony and little else is visible. The material generally referred to the "sextans" group taxa by Mu et al. (1993), e.g. Phormograptus hubeiensis $\mathrm{Mu}$, "Paraplegmatograptus" sextans $\mathrm{Mu}$ and Phormograptus sinensis Mu, present this aspect. In contrast, "connectus" group taxa typically are specimens preserved in profile view (commonly box flattened - that is, showing one lateral surface of the rhabdosome plus one apertural surface), that have been infilled with sediment and have had much of the exterior pleural mesh peeled off when the slabs were split or were preserved in scalariform and subscalariform views that naturally present a less complex mesh.

Proximal development of this species appears to be similar to that of the type material of Phormograptus sooneri (= Ph. sooneri type B of Bates \& Kirk 1991). The descending part of th $1^{1}$ is normally developed but the metatheca of both th $1^{1}$ and th $1^{2}$ are represented only by a long, single median ventral list and an apertural loop that is otherwise not connected to the thecal framework.

The nomenclatural history of species referred to this taxon is complex. Chen et al. (2000, 2005a) have employed "Paraplegmatograptus" connectus as the senior synonym for the group, in which they included Phormograptus? hubeiensis $\mathrm{Mu}$. Both species names were made available on the same page by Wang et al. (in Stratigraphy Research
Group of the Yangtze Gorges, Hubei Bureau of Geology ed. 1978). Since clingfilm preservation is relatively rare, $P h$. connectus-like specimens are much more common than Ph. hubeiensis-like specimens and so is the much more widely used name. Mu et al. (1993) excluded the material referred to Paraplegmatograptus connectus $\mathrm{Mu}$ in Wang et al. (lc) from their synonymy and referred to that taxon instead as Phormograptus connectus Wang (in Wang et al., 1978) - a distinction that we reject. Thus, we include all this material within one taxon and recommend retaining the name Phormograptus connectus $\mathrm{Mu}$ (in Wang et al., 1978) for this species.

\section{Phormograptus sp.}

Figure 20G

Material and stratigraphical range. - One incomplete flattened specimen from lime mudstone of the lowermost pacificus Zone. Vinini Creek section.

Remarks. - Minute rhabdosome tentatively designated as Phormograptus sp. exhibits dense reticulum, and $0.9 \mathrm{~mm}$ long normally developed metasicula. Prosicula, in turn is missing due to either preservational or biological reasons. $4.8 \mathrm{~mm}$ long rhabdosome widens from $\mathrm{ca} 0.7 \mathrm{~mm}$ measured at the level of the first thecal pair to the maximum of ca $1.7 \mathrm{~mm}$ (including poorly preserved lacinia) attained near the distal end. Internal width confined to thecal framework is just $0.9 \mathrm{~mm}, 2 \mathrm{TRD}_{5}$ is $0.95 \mathrm{~mm}$. The rhabdosome is readily distinguishable from all other currently known phormograptids and related lasiograptid forms by its minute dimensions, dense thecal spacing and relatively large sicula.

\section{Genus Yinograptus Mu in Mu \& Chen, 1962}

Type species. - Gothograptus disjunctus Yin \& Mu, 1945, p. 216, pl. 1, fig. 3a; designated by Mu \& Chen (1962). 
Definition. - Lasiograptids with obverse and reverse walls reduced to regular clathrium consisting of lateral lists and dorsal lists and sparse planar reticulum that is linked to nema by prominent spines (scopulae). Scopulae project outward from lateral walls at regular intervals, generally at every fourth thecal pair. Somewhat delicate lacinia surrounds the sicular region and is confined to apertural margins of colony more distally. Proximal development not well known.

\section{Yinograptus disjunctus (Yin \& Mu, 1945)}

Figures 16I, O, P, 20A, I, J

1945 Gothograptus? disjunctus Yin \& Mu; Yin \& Mu, p. 216, pl. 1, figs 3, 3a.

1962 Yinograptus disjunctus (Yin \& Mu). - Mu \& Chen, p. 112 , pl. 18 , fig. 4 .

1978 Yinograptus brevispinus Mu. - Wang et al., p. 347, pl. 105, fig. 6a, b.

1978 Yinograptus disjunctus (Yin \& Mu). - Wang et al. (in Stratigraphy Research Group of the Yangtze Gorges, Hubei Bureau of Geology ed.), p. 210, pl. 50, fig. 7.

1978 Yinograptus robustus; Mu (in Wang et al., in Stratigraphy Research Group of the Yangtze Gorges, Hubei Bureau of Geology ed.), p. 210, pl. 50, fig. 9.

1984 Yinograptus disjunctus (Yin \& Mu). - Mu \& Lin, p. 67 , pl. 8 , fig. 3 .

1993 Yinograptus disjunctus (Yin \& Mu). - Mu (in Mu et al.), pp. 249-251, pl. 63, fig. 6; pl. 64, figs 1-6; pl. 65, fig. 1; text-fig. 53a-c.

1993 Yinograptus robustus Mu. - Mu (in $\mathrm{Mu}$ et al.), pp. 251,252 , pl. 61 , fig. 5 ; pl. 63 , figs 3,7 ; pl. 65 , figs 3 , 4; text-fig. $54 \mathrm{a}-\mathrm{c}$ (see for further reference on Y. robustus).

1993 Yinograptus gracilispinus $\mathrm{Mu}$ (sp. nov.). - Mu (in Mu et al.), pp. 253, 254, pl. 66, figs 1, 5; text-fig. 56a, b.

1993 Yinograptus brevispinus $\mathrm{Mu}$ - - Mu (in Mu et al.), pp. 254,255 , pl. 65 , figs $6-8$; text-fig. $57 \mathrm{a}-\mathrm{c}$ (see for further reference on $Y$. brevispinus).

Material and stratigraphical range. - Eight more-or-less complete, flattened rhabdosomes from the ornatus and $p a-$ cificus zones of the Vinini Creek and Martin Ridge sections. Specimens are moderately well preserved in limemudstones, mudstones and black shales.

Description. - Proximal end of rhabdosome poorly preserved; neither sicula nor virgella visible in present material. Rhabdosome width $\sim 1 \mathrm{~mm}$ proximally, 1.7-2.4 $\mathrm{mm}$ at th3, $1.9-2.55 \mathrm{~mm}$ at th5 and $3.0-3.5 \mathrm{~mm}$ at th10; maximum: 3.4-3.6 mm in most distal part of mature, $25 \mathrm{~mm}$ long specimens. Rhabdosomal framework with regular subhexagonal panels, somewhat wider than tall, formed by ro- bust clathria of lateral and dorsal lists with sparse reticulum. Irregular reticular meshwork composed of tetragonal to hexagonal meshes well developed proximally but almost disappears distally suggesting that reticular development lagged behind that of the thecal frame. Obverse and reverse pleural panels linked by robust apertural lists and post-apertural lists. Prominent septal spines arise either from dorsal lists or central nema (and thus form cross-bars that link the nema to the thecal frame), usually at each fourth theca, project horizontally in proximal regions but becoming reclined at an angle of about $45^{\circ}$ distally. Specimens commonly flattened in scalariform orientation because of long scopulae and so exhibit regular hexagonal framework of thecal apertures, flanked by outwardly compressed thecal frame and reticulum, and depending on taphonomy, overlain by thin lacinia threads. Delicate lacinia arises from median apertural spines with fine threads linking back to the lateral lists, especially near midpoint between successive apertures. Lacinia confined to apertural (ventral) margins of the colony but merges with reticulum that surrounds sicular end of colony. Thecae number about 5 in $5 \mathrm{~mm}$ proximally $\left(2 \mathrm{TRD}_{5}: 1.9-2.0 \mathrm{~mm}\right)$ and $7.5-8$ in $10 \mathrm{~mm}$ distally $\left(2 \mathrm{TRD}_{\text {dist }}: 2.6-2.7 \mathrm{~mm}\right)$.

Remarks. - As in Phormograptus connectus the thecal frame is linked to the nema but in this case is much more strongly developed, including, as in Paraplegmatograptus uniformis, well developed lateral lists, but unlike the latter, with much more regularly developed thecal frame and more sparse reticulum. Like the latter, $Y$. disjunctus differs also from $P h$. connectus in that in these species the lacinia is confined to the apertural margins of the colony. Several different species of Yinograptus have been described (listed in the synonymy above) but these differ primarily in minor features of their dimensions, extent of secondary elaboration of the reticulum and lacinia, or lengths of the scopulae. Re-examination of Wufeng collections by Chen et al. (2000, 2005a) suggests that these taxa may be part of a continuum of variation in these features rather than separate species. Given the considerable taphonomic and astogenetic variation associated with this and the other retiolite-type lasiograptids, we also prefer to take the conservative approach and treat all these taxa as synonymous.

Superfamily Climacograptoidea Frech, 1897, emend. Mitchell et al. 2007b

Discussion. - Recent cladistic analyses (Mitchell 1987, Cone 2004) and previous evolutionary scenarios (Riva \& Ketner 1989, Vandenberg 1990, Rickards et al. 2001) differ on several critical aspects of the phylogenetic relations among species of this group. Although we have in general 
followed the results of Mitchell et al. (2007b) in preceding taxonomic re-evaluations, Cone's (2004) analysis provides a more detailed study of the species of Climacograptus and so helps to resolve the relationships among taxa examined here. Cone (lc) coded 82 discrete characters and 14 continuous features of colony dimensions rendered into ordered, discrete character states by finite mixture coding (Strait et al. 1996) for fifteen in-group climacograptid species, including members of Diplacanthograptus and Appendispinograptus, as well as three out-group taxa (Archiclimacograptus modestus, Ar. meridionalis, and Pseudoclimacograptus scharenbergi). The analysis was aimed specifically at evaluating the several competing phylogenetic hypotheses and the position of the genera Ensigraptus Riva (in Riva \& Ketner 1989) and Euclimacograptus Riva (in Riva \& Ketner 1989). Cone's (2004) analysis produced good resolution among late Katian climacograptids with strong support for nodes defining three terminal clades: Appendispinograptus and Diplacanthograptus, which together are sister to Styracograptus n. gen. Styracograptus n. gen. is a taxon group of derived and simplified 'climacograptids' that we name herein. Climacograptus bicornis and its close relatives (including C. hastatus) form a stem lineage between this set of clades and an unresolved polychotomy containing the outgroup taxa. The sister-group relations below the basal nodes of these three genera did not receive greater than $50 \%$ bootstrap support, however, and so are not strongly supported by the available data (Cone 2004). Subsequent analysis (Mitchell et al. 2007b) suggests that Ps. scharenbergi may be a sister taxon to the Climacograptus clade (based on the set of synapomorphic features associated with the Pattern D proximal structure shared by $P$ s. scharenbergi, C. bicornis and the other species in this clade below the common ancestor of Appendispinograptus and Diplacanthograptus) with $69 \%$ bootstrap support for the node uniting all these taxa. The analysis reported by Mitchell et al. (2007b) placed Styracograptus tubuliferus and $S$. putillus at the base of the climacograptid clade rather than as sister to $A p$ pendispinograptus + Diplacanthograptus. The uncertainty about these relationships leads us to define the climacograptid taxa based on their morphological apomorphies rather than by lineage or node specifiers.

\section{Genus Climacograptus Hall, 1865, emend. herein}

Type species. - Graptolithus bicornis J. Hall, 1847, p. 268; original designation, from the Late Ordovician (Sandbian) of New York State, USA.

Diagnosis. - Paraphyletic stem group comprising species sharing a pattern D proximal structure, sharply geniculate thecae with straight supragenicular walls, simple deep se- micircular thecal excavations, weakly undulose to straight median septum and subapertural to mesial spines on the first pair of thecae and excluding those Pattern E-bearing species with large basal spines included in Appendispinograptus and Diplacanthograptus, and the species without thecal spines grouped in Styracograptus n. gen., defined below.

Discussion. - The scope of the genus Climacograptus has undergone substantial revision in recent decades. Many homeomorphic species, formerly thought to belong to the genus, occur within Geniculograptus and Anticostia (among the Diplograptidae) and within Normalograptus. In addition, the genus has been subdivided, a trend that we continue here. Riva (in Riva \& Ketner 1989) proposed two new genera for species in this clade: Euclimacograptus and Ensigraptus. Riva stated that the former was intended to encompass "all advanced climacograptids... with a pronounced final upward growth of the first two thecae (in Riva \& Ketner 1989, p. 82)". He noted that, like C. bicornis itself, these species all possess prominent mesial spines on the first two thecae and that they share with the type species the pattern D proximal structure. Thus, the only difference specified is the upward growth of the first two thecae. Nevertheless, Riva (lc, p. 78) excluded Climacograptus cruciformis Vandenberg, 1989 from Euclimacograptus despite the fact that this species clearly has strongly upward directed first and second thecae. Indeed, this proposed redefinition would essentially restrict the name Climacograptus to the type species. We see no advantage to this redefinition and retain C. hastatus and similar forms within Climacograptus. The distinction that Riva (lc) intended with the genus Ensigraptus, however, does have merit and subsequently has been employed by others in their work. Unfortunately the definition of this taxon is seriously flawed. We propose the name Styracograptus for the part of the climacograptid clade that the name Ensigraptus was meant to signify and explain the rationale for this change in the corresponding discussion below.

\section{Climacograptus hastatus T.S. Hall, 1902}

Figures 21A, B, L-N, 22D, F, L, Table 16

1902 Climacograptus hastatus; T.S. Hall, p. 5, pl. 14, figs 1-3.

1963 Climacograptus hastatus T.S. Hall. - Ross \& Berry, p. 121, pl. 6, figs 8, 10 .

1963 Climacograptus hastatus var. angustus n. var.; Ross \& Berry, pp. 122, 123, pl. 9, fig. 22.

1966 Climacograptus hastatus T.S. Hall. - Berry, p. 162, pl. 21, figs 1-4, text-fig. 1.

1977 Climacograptus hastatus T.S. Hall. - Carter \& Churkin, p. 22, pl. 4, fig. 7. 
Table 16. Climacograptus hastatus. Dimensions of illustrated specimens (in mm).

\begin{tabular}{|c|c|c|c|c|c|c|c|c|c|}
\hline \multirow{2}{*}{ Specimen USNM } & \multirow{2}{*}{ Text-figure } & \multicolumn{4}{|c|}{$\mathrm{W}$} & \multicolumn{4}{|c|}{ 2TRD } \\
\hline & & th1 & th5 & th10 & dist. max & th2 & th5 & th10 & dist. th \\
\hline 542726 & $21 \mathrm{~A}$ & 0.7 & 1.3 & 1.95 & 1.95 & 1.35 & 1.9 & 2.05 & 2.0 \\
\hline 542658 & $21 \mathrm{~B}$ & 0.55 & 1.15 & 1.6 & $>1.8$ & $?$ & 1.65 & 2.1 & - \\
\hline 542669 & $21 \mathrm{~L}$ & 0.8 & 1.6 & - & - & 1.45 & 1.5 & - & - \\
\hline 542754 & $21 \mathrm{M}, 22 \mathrm{~L}$ & 0.6 & 1.35 & 2.0 & 2.0 & 1.2 & 1.75 & 2.0 & 2.15 \\
\hline 542666 & $21 \mathrm{~N}, 22 \mathrm{D}$ & 0.7 & 1.3 & 1.7 & - & 1.45 & 1.65 & $?$ & - \\
\hline 542826 & $22 \mathrm{~F}$ & 0.7 & 1.5 & - & - & 1.25 & 1.5 & - & - \\
\hline 542829 & - & $?$ & 1.4 & 1.85 & 2.4 & 1.3 & 1.5 & 1.85 & 2.25 \\
\hline
\end{tabular}

1983 Climacograptus hastatus T.S. Hall, 1902. - Koren’ \& Sobolevskaya (in Koren' et al.), pp. 112, 115, 116; pl. 29, figs 3-8; pl. 30, fig. 1; text-figs 37, 38.

1984 Climacograptus hongtanensis sp. nov.; Li, pp. 172, 173, pl. 7, figs 6, 7; text-fig. 7b.

1984 Climacograptus ef. hastatus T.S. Hall. - Li, p. 172, pl. 10, fig. 15.

1989 Euclimacograptus hastatus (T.S. Hall). - Riva (in Riva \& Ketner), p. 82, figs 8, 9a-c.

1993 Climacograptus hastatus T.S. Hall. - Ge (in Mu et al.), p. 161, pl. 36, figs 1-7.

1993 Climacograptus hastatus finis $\mathrm{Ge}, 1983$. - Ge (in $\mathrm{Mu}$ et al.), p. 162, pl. 31, fig. 9; pl. 37, figs 1-5.

1993 Climacograptus hastatus tentaculatus subsp. n.; Ge (in $\mathrm{Mu}$ et al.), p. 163, pl. 36, figs 8, 9, 11, 12; pl. 37, figs 7-10.

1993 Climacograptus hastatus tumidulus subsp. n.; Ge (in Mu et al.), pp. 163, 164, pl. 38, figs 16, 17.

1993 Climacograptus abnormispinus sp. n.; Ge (in $\mathrm{Mu}$ et al.), pp. 154, 155, pl. 29, figs 14, 15.

1993 Climacograptus acutus sp. n.; Ge (in $\mathrm{Mu}$ et al.), p. 155 , pl. 29, figs $1-7$; pl. 30, fig. 1 .

1993 Climacograptus cf. tridentatus Lapworth. - Ge (in Mu et al.), pp. 167, 168, pl. 35, figs 4, 5 .

1997 Climacograptus hastatus Hall, 1902. - Goldman \& Bergström, text-fig. $13 \mathrm{H}$.

2002 Euclimacograptus hastatus (T.S. Hall). - Mu et al., pp. 667, 668, pl. 185, figs $1,2$.

2005a Climacograptus hastatus T.S. Hall (1902). - Chen et al., pp. 247, 248, pl. 3, fig. 2; text-fig. 5G, O, R.

Material and stratigraphical range. - Common species that ranges from the ornatus Zone to the pacificus Zone in the Vinini Creek and Monitor Range sections becomes fairly uncommon in the upper part of the pacificus Zone. More than 60 flattened rhabdosomes (21 measured in detail) came from varied limestones, lime mudstones, mudstones and black shales.

Description. - The robust rhabdosome rapidly widens from $0.55-0.8 \mathrm{~mm}$ across the first thecal pair, through
$1.15-1.6 \mathrm{~mm}$ at th5 to $1.6-2.0 \mathrm{~mm}$ at th10. Mature, more than $20 \mathrm{~mm}$ long rhabdosomes are 1.75-2.4 mm wide in the distal part. There are three or four basal spines seen in the proximal end of the rhabdosome: thick, up to $\mathrm{ca} 10 \mathrm{~mm}$ long virgella, straight, $0.8-2.9 \mathrm{~mm}$ long, ventrally directed mesial spines on th $1^{1}$ and $1^{2}$, directed about perpendicular to the rhabdosome, and one of two spines growing from lateral walls at the basal end of the rhabdosome. In mature rhabdosomes the sicula further extends downwards, along the virgella, with a $2.0-4.8 \mathrm{~mm}$ long secondary tubular parasicula. Secondary thickening at the basal end of the late mature rhabdosomes may be accompanied by further thickening of both virgella and other basal spines. Mature rhabdosomes also possess a robust, $c a 0.2 \mathrm{~mm}$ wide nema, projected $<20 \mathrm{~mm}$ beyond the thecate part. The thecae are climacograptid, with parallel-sided or slightly inclined supragenicular walls, strong geniculum and roughly semicircular apertural excavations that are somewhat asymmetric in profile. Supragenicular walls $0.4-0.5 \mathrm{~mm}$ long in proximal thecae, $0.5-0.65 \mathrm{~mm}$ in distal thecae. Apertural excavations are $0.2-0.3 \mathrm{~mm}$ wide proximally and $0.3-0.5 \mathrm{~mm}$ wide distally. 2TRD increases from $1.1-1.45 \mathrm{~mm}$ at th2, through $1.4-1.8 \mathrm{~mm}$ at th5 and $1.7-2.1 \mathrm{~mm}$ at th10, to distal $\max .2 .0-2.2 \mathrm{~mm}$.

Remarks. - Many species and subspecies have been erected (Li 1984, Mu et al. 1993) due to both primarybiological and secondary-preservational variation of this species, namely with regard to its parasicula and basal spines that get very robust in fully mature rhabdosomes. Ross \& Berry (1963) and Berry (1966) recognized eight morphological varieties within $C$. hastatus. Specimens from Vinini Creek and Martin Ridge sections are of rather uniform morphology with variation that can be readily accounted for by differences in preservation and astogenetic maturation. Immature rhabdosomes have short spines and virgella and a rather blunt proximal end of the rhabdosome, without secondary thickening, corresponding with the population figured by Riva \& Ketner (1989, fig. 8) from Sonora, Mexico, whereas large rhabdosomes are closely comparable to the type material from Australia. 


\section{Genus Styracograptus gen. nov.}

Type species. - Climacograptus tubuliferus Lapworth, 1876; from the Late Ordovician (Katian) of Scotland, UK.

Derivation of name. - From the Greek styracos $(\sigma \tau \cup \rho \alpha-$ $\kappa о \varsigma)$ : the spike at the butt end of a lance; in reference to the single prominent spine (virgella) that projects from the otherwise unadorned, rod-like colony.

Diagnosis. - Climacograptoidea species that jointly possess a Pattern D proximal structure, a sicula in which the normal prosicula is replaced by a single prominent rod that is continuous with the nema, and that lack spines on the proximal thecae.

Description. - Rhabdosomes generally robust, nearly cylindrical with a prominent virgella (often several $\mathrm{mm}$ in length) and commonly a thickened nema or elongate, vane-like nematularium (as in the type species). As in Pseudoclimacograptus and Climacograptus, the proximal structure somewhat derived: th $1^{2}$ formed a broad arch across reverse side of sicula. Th $2^{1}$ protheca formed a short tubular hood on dorsal side of th $1^{2}$ crossing canal. Subsequent growth of reverse wall of th $2^{1}$ entirely surrounded this tube but a small patch corresponding to a connecting bar at the mouth of the tube may be visible when specimens are preserved in relief (see Mitchell 1987, text-fig. 5; NB, contrary to the identification given there these are specimens of S. tubuliferus Lapworth). Some species aseptate [e.g., Styracograptus tatianae (Keller)] but th $2^{2}$ or some later theca dicalycal in septate species and median septum straight to slightly undulose proximally (e.g., S. putillus) or markedly zigzag, as in Pseudoclimacograptus. Unlike species of Pseudoclimacograptus, however, thecae in species of Styracograptus have open, semicircular apertures, straight supragenicular walls and the interthecal septa do not fold around the zigzag median septum.

Remarks. - In addition to the type species, this small clade appears to include Climacograptus chiai $\mathrm{Mu}, 1949$, C. missilis Keble \& Harris, 1925; C. miserabilis Elles \& Wood, 1906; C. mississippiensis Ruedemann, 1908; C. nevaden- sis Carter, 1972; C. putillus Hall, 1865; C. styloideus Elles \& Wood, 1906; C. spicatus Ge, 1984; C. tatianae Keller, 1956; and C. uncinatus Keble \& Harris, 1934. Species of this group are closely similar to some species of Normalograptus, such as N. ajjeri, N. angustus, N. mohawkensis, and $N$. normalis, among others that are reported from the Late Ordovician. Several features of Styracograptus species permit their ready distinction in well-preserved material. The most direct of these is proximal structure. All species of Normalograptus have a Pattern $\mathrm{H}$ proximal structure in which the first thecal pair form a narrow, rather pointed proximal end (in contrast to the more evenly and broadly rounded proximal end of the climacograptids) and in which th $2^{1}$ and all subsequent thecae exhibit the simple distal thecal ontogeny (in contrast to the more complex ontogeny of th $2^{1}$ in the Pattern D proximal structure). These features require exceptional preservation to be evident, however. Normalograptus species also retain a normal sicula with a complete prosicula and central nema. In climacograptids the prosicula is replaced by secondary structures: either by a stirrup-shaped pair of rods that unite to form the base of the nema (e.g., C. bicornis, C. cruciformis, and Diplacanthograptus and Appendispinograptus species; Mitchell 1987, Cone 2004) or by a single rod that arose from the lateral margin of the apex of the metasicula. These structures, particularly the truncated apex of the metasicula and the lateral stout rod/nema of the Styracograptus and C. hastatus-group species are often visible pressed through the lateral rhabdosome walls in well preserved compressed material. Finally, most climacograptids (including Styracograptus) have prominent thickened lists at the base of the alternate dorsal walls that, among septate species, form the median septum. These lists pass from the lateral rhabdosome walls through the median septum (typically quite delicate) and anchor on the nema. Thus, they form a series of nema crossbars that are regularly spaced along the colony opposite each thecal aperture. Nema crossbars are entirely unknown in specimens of Normalograptus. Again, these structures are commonly visible pressed through flattened climacograptid material (e.g., Mitchell 1987, text-fig. 7K, L; Riva \& Ketner 1989, figs 8a-e, 9j) and in specimens preserved in full relief, the point of insertion of the crossbars on the lateral walls are often visible as distinct dimples. In

Figure 21. A, B, L-N - Climacograptus hastatus T.S. Hall, 1902: A - USNM 542726, level 7.65 m; B - USNM 542658, level 4.40 m; L - USNM 542670, level 7.75 m; M - USNM 542754, level MR 96.13 m; N - USNM 542666, level 6.10 m. • C-F, J, P, Q - Styracograptus mississippiensis Ruedemann, 1908: C - USNM 542657, level 4.40 m; D - USNM 542749, level MR 112.8 m; E - USNM 542729, level 4.40 m; F - USNM 542685a, P - USNM 542685b, level $7.65 \mathrm{~m}$; J - USNM 542704, level $11.70 \mathrm{~m}$. Q - 542740, level MR $95.00 \mathrm{~m}$. • G - Styracograptus cf. tatianae Keller, 1956 : USNM 542777, level MR $105.2 \mathrm{~m}$. H, I, O, R-U - Styracograptus tatianae Keller, 1956: H - USNM 542732, level 9.80 m; I - USNM 542661, level $4.40 \mathrm{~m}$; O - USNM 542820, level 27,85 m; R - USNM 542752, level MR $96.13 \mathrm{~m} ; \mathrm{S}$ - USNM 542736, level $18.80 \mathrm{~m}$; T - USNM 542788 , level 18.80 m; U - USNM 542836, level $18.80 \mathrm{~m}$. $・ \mathrm{~K}$ - Styracograptus sp.: USNM 542785, level $18.00 \mathrm{~m}$. • USNM 542657, 542658, 542661, 542666, 542670, 542685a, b, 542726, 542729, 542740, 542752 and 542754 from the ornatus Biozone, USNM 542704, 542732, 542736, 542749, 542777, 542785, 542788 and 542836 from the pacificus Biozone and USNM 542820 from the persculptus Biozone. A-C, E, F, H-L, N-P, S-U from the Vinini Creek section, D, $\mathrm{G}, \mathrm{M}, \mathrm{Q}, \mathrm{R}$ from the Martin Ridge section. All figures $\times 6$. Scale bar equals $1 \mathrm{~mm}$. 
Petr Štorch et al. • Uppermost Ordovician graptolites of north-central Nevada

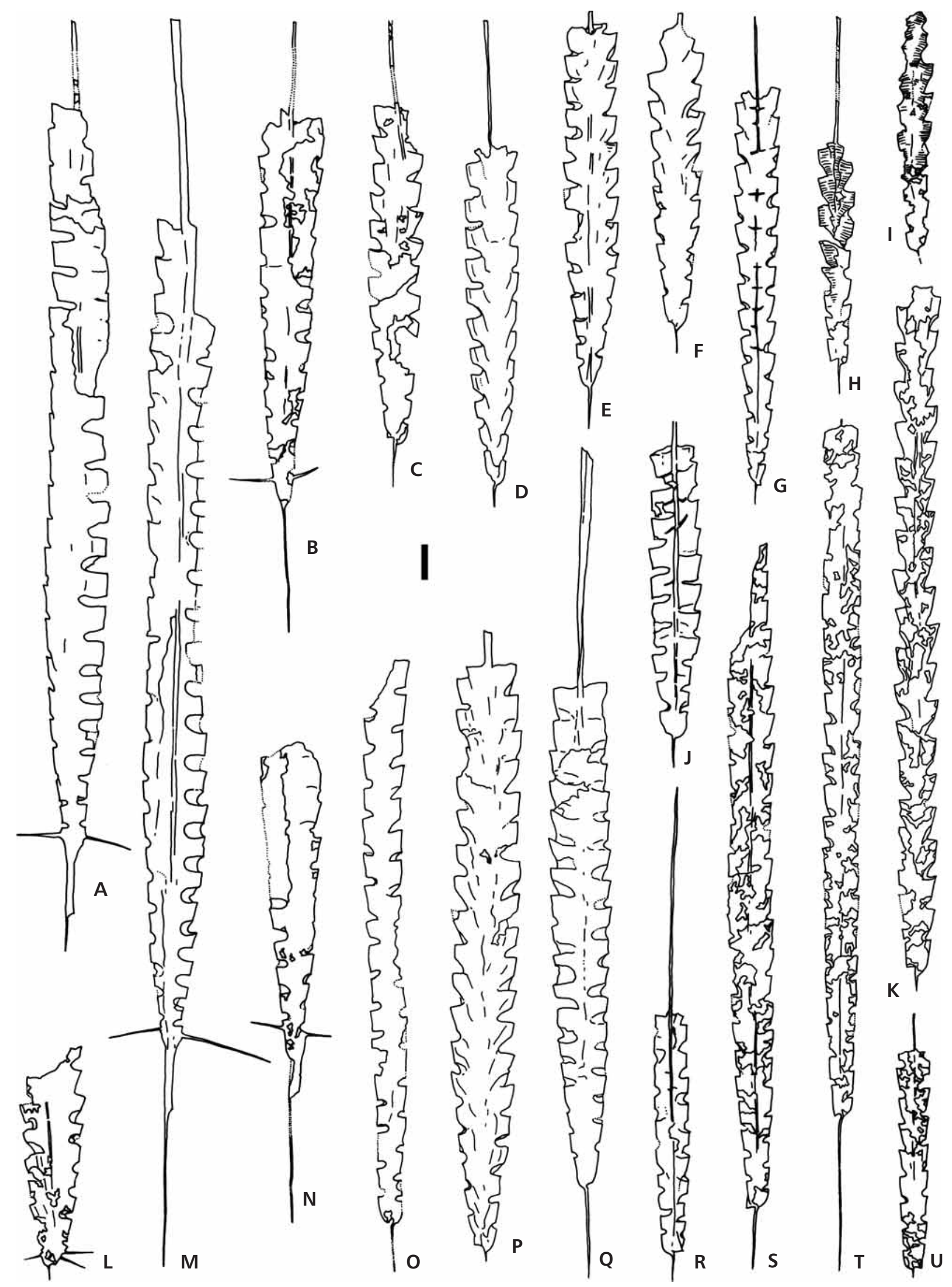


addition, species of Styracograptus commonly show a more robust nema than those of Normalograptus, and the virgella in Styracograptus shows a slight deflection across the sicular aperture before turning straight downward, which is not common in Normalograptus.

In his revision of Climacograptus, Riva (in Riva \& Ketner 1989) transferred $C$. tubuliferus to the genus Normalograptus. Type specimens of this species have a rounded proximal end, parasicula, and prominent nematularium, all of which are very unusual features in Normalograptus but are commonly present in climacograptids. Mitchell (1987) figured isolated specimens that appear to belong to this species (but which he misidentified as C. sp. cf. C. caudatus, see Goldman \& Wright 2003) that exhibit a Pattern D proximal end. In specimens that Riva (in Riva \& Ketner 1989, fig. 11b-d) referred to $C$. tubuliferus, the nema arose from the lateral margin of a truncated sicula and nema crossbars are well developed in the proximal region, although, we regard these particular specimens as members of the younger but closely similar species, Styracograptus mississippiensis (Ruedemann), which we redescribed below. We are confident that $C$. tubuliferus indeed is a member of the climacograptid clade here named Styracograptus rather than a species of Normalograptus.

Riva (in Riva \& Ketner 1989) unambiguously meant the name Ensigraptus to apply to the group of simplified climacograptids that lack proximal spines other than the virgella. In his definition, however, Riva chose Climacograptus caudatus Lapworth as the type species. This turns out to have been an unfortunate choice for it is now apparent that the prominent spine present in this species is actually a strongly downward-grown and hypertrophic th $1^{1}$ mesial spine rather than the virgella (Goldman \& Wright 2003). The virgella, in contrast, was very short and typically was hidden in mature specimens within a parasicula that grew out of the sicular aperture and down the th $1^{1}$ spine. In addition, $C$. caudatus exhibits the more derived Pattern E proximal structure, which it shares with Diplacanthograptus spiniferus and members of Appendispinograptus (Goldman \& Wright 2003). Thus, this species belongs to Diplacanthograptus and, consequently, Ensigraptus must be regarded as a junior synonym of Diplacanthograptus, despite its author's intent. Recent phylogenetic analyses (Cone 2004, Mitchell et al. 2007b) support the suggestion that the group that Riva meant to name Ensigraptus is indeed a distinct clade and that it merits a new name. Thus, we offer Styracograptus.

Stratigraphical range. - The species of Styracograptus first appeared during the Katian Stage, became extinct during the Hirnantian Stage, and thus were confined to the Late Ordovician.

\section{Styracograptus mississippiensis (Ruedemann, 1908)}

Figures 21C-F, J, P, Q, 22A, B, E, H, M, Table 17

cf. 1906 Climacograptus tubuliferus Lapworth; Elles \& Wood, pp. 203, 204, pl. 27, fig. 8a-d; text-fig. 134a, b.

1908 Climacograptus mississippiensis n. sp.; Ruedemann, pp. 413, 414 (partim), pl. 28, fig. 12; text-fig. 366 (non pl. 28, fig. 13; text-fig. 367).

1963 Climacograptus cf. C. mississippiensis (Ruedemann). - Ross \& Berry, p. 126, pl. 8, fig. 20; text-fig. 2.

1971 Climacograptus mississippiensis Ruedemann. Berry \& Marshall, pp. 255, 256, text-fig. 3e-i.

1983 Climacograptus tubuliferus Lapworth. - Koren' \& Sobolevskaya (in Koren' et al.), pp. 139-141 (partim), pl. 40, figs 6, 7, 9; text-fig. 51a-e, к (non pl. 40, figs. 8, 10, 11; text-fig. 51ж-и, н-л).

?1984 Climacograptus cf. angustus (Perner). - Li, p. 168, pl. 5, fig. 8; text-fig. 6 a.

1989 Normalograptus tubuliferus (Lapworth, 1876). Riva \& Ketner, pp. 87-89, text-fig. 11a-e (non text-fig. 10a-i).

1997 Climacograptus tubuliferus Lapworth, 1876. - Goldman \& Bergström, pp. 991, 993; text-figs 12A-H, ?13A-D, I-K; pl. 2, figs 1-3.

Material and stratigraphical range. - The species is abundant in both the ornatus Zone and the pacificus Zone in the Vinini Creek and Monitor Range sections. More than 100 flattened and several low-relief rhabdosomes have been preserved in varied limestones, lime mudstones, mudstones and black shales. Detailed biometric data came from 42 specimens.

Description. - Rhabdosome of moderate size with maximum length of $23.5 \mathrm{~mm}$. Width at the first thecal pair $0.55-0.95 \mathrm{~mm}$, increasing through $1.15-1.85 \mathrm{~mm}$ at th5 to a maximum of 1.5-2.0 $\mathrm{mm}$ attained by th6-th10 or later (Table 17). Truncated conical sicula $\sim 1.0 \mathrm{~mm}$ long (up to $1.7 \mathrm{~mm}$ including the secondary rod that replaces the prosicula) and $0.2-0.3 \mathrm{~mm}$ wide at the aperture. The sicula is furnished with $0.4-2.0 \mathrm{~mm}$ long virgella $(3.85 \mathrm{~mm}$ in extreme) which is commonly seen to be initially deflexed across aperture margin before it turns straight down. Mature rhabdosomes with strong, 0.4-0.6 mm wide nema, which extends far beyond distal thecae. Rather strong nema crossbars are commonly pressed through lateral walls of aseptate rhabdosome. Thecae climacograptid, with prominent geniculum and parallel-sided or slightly inclined supragenicular walls. $2 \mathrm{TRD}_{2} 1.4-1.8 \mathrm{~mm}$ increasing to $1.6-2.0 \mathrm{~mm}$ at th10. Distal thecae number $c a 10$ in $10 \mathrm{~mm}$ $\left(2 \mathrm{TRD}_{\text {dist }} 1.85-2.1 \mathrm{~mm}\right)$.

Remarks. - Ruedemann (1908) described the new species Diplograptus crassitestus and Climacograptus mississip- 
Petr Štorch et al. • Uppermost Ordovician graptolites of north-central Nevada

Table 17. Styracograptus mississippiensis. Dimensions of type material (Ruedemann 1908) and illustrated specimens (in mm).

\begin{tabular}{|c|c|c|c|c|c|c|c|c|c|}
\hline \multirow{2}{*}{\multicolumn{2}{|c|}{ Specimen USNM Text-figure }} & \multicolumn{4}{|c|}{$\mathrm{W}$} & \multicolumn{4}{|c|}{ 2TRD } \\
\hline & & \multirow{2}{*}{$\begin{array}{c}\text { th1 } \\
0.75\end{array}$} & \multirow{2}{*}{$\frac{\text { th5 }}{1.5}$} & \multirow{2}{*}{$\begin{array}{l}\text { th } 10 \\
1.5\end{array}$} & \multirow{2}{*}{$\begin{array}{c}\text { dist. max } \\
-\end{array}$} & \multirow{2}{*}{$\frac{\text { th2 }}{1.5}$} & \multirow{2}{*}{$\begin{array}{c}\text { th5 } \\
1.65\end{array}$} & \multirow{2}{*}{$\frac{\text { th10 }}{1.7}$} & \multirow{2}{*}{$\begin{array}{l}\text { dist. th } \\
-\end{array}$} \\
\hline 542657 & $21 \mathrm{C}$ & & & & & & & & \\
\hline 542749 & $21 \mathrm{D}, 22 \mathrm{~B}$ & 0.55 & 1.3 & 1.6 & - & 1.5 & 1.7 & 1.9 & - \\
\hline 542729 & $21 \mathrm{E}, 22 \mathrm{E}$ & 0.7 & 1.5 & 1.55 & - & 1.4 & 1.6 & 1.6 & - \\
\hline $542685 a$ & $21 \mathrm{~F}$ & 0.7 & 1.45 & 1.6 & - & 1.5 & 1.7 & - & - \\
\hline $542685 b$ & $21 \mathrm{P}, 22 \mathrm{M}$ & 0.75 & 1.5 & 1.75 & 1.75 & 1.45 & 1.7 & 1.85 & 2.0 \\
\hline 542740 & $21 \mathrm{Q}, 22 \mathrm{H}$ & 0.75 & 1.55 & 1.6 & 1.6 & 1.45 & 1.5 & 1.85 & 1.85 \\
\hline 542660 & $22 \mathrm{~A}$ & 0.8 & 1.6 & - & - & 1.5 & 1.5 & - & - \\
\hline 54268 & holotype Rued. & 0.9 & 1.54 & 1.62 & 1.62 & 1.43 & 1.7 & 1.8 & - \\
\hline 240638 & paratype Rued. & 0.78 & 1.45 & 1.6 & 1.8 & 1.32 & 1.82 & 2.0 & 2.0 \\
\hline dtto & paratype Rued. & 0.73 & 1.4 & 1.8 & - & 1.37 & 1.77 & - & - \\
\hline 242263 & paratype Rued. & 0.8 & 1.15 & 1.2 & - & 1.5 & 1.7 & - & - \\
\hline
\end{tabular}

piensis on the basis of a sample from the Di. complanatus Zone within the Sylvan Shale near Davis Oklahoma, USA. Unfortunately, the type series of both of these taxa includes representatives of several species. The holotype of D. crassitestus (USNM 54266) is the distal part of a somewhat poor specimen of a species of Diplograptus sensu stricto (see discussion of Diplograptus above) as is the paratype USNM 235605 (see Goldman \& Bergström 1997, text-fig. 12I, J, respectively). Ruedemann (1908, 1947) only illustrated the holotype at $\times 1$ but gave a more useful illustration of a paratype, USNM 240638 (Ruedemann 1908, fig. 299; reprinted in 1947, pl. 71, fig. 4; Goldman \& Bergström 1997, text-fig. 12H). This specimen belongs to Styracograptus mississippiensis (Ruedemann) and, consequently, has mislead subsequent authors (e.g. Berry 1970). This specimen has a strongly climacograptid proximal end, deep semicircular apertures and the wandering nema characteristic of flattened aseptate rhabdosomes. Crossbars are also evident on the nema up to near the distal end of the specimen where the nema splits to form a flat nematularium bounded by the nema strands. A second specimen of S. mississippiensis with 10 well preserved proximal thecae is also present on the slab with USNM 240638, and exhibits a pattern D proximal structure with the typical truncated apex of the sicula visible pressed through the lateral wall of the colony as well as a distal nematularium with lateral thickenings. The holotype of S. mississippiensis (USNM 54268) is a well-preserved semi-relief specimen with a complete proximal end, but the distal part is now obscured by glue that was employed to stick down the loose specimen. The holotype appears to be aseptate throughout and has strongly developed indentations along the midline at the insertion points of the nema crossbars. The paratype of S. mississippiensis (USNM 242263, Ruedemann 1908, fig. 367; Goldman \& Bergström 1997, text-fig. 12G) is much narrower. It reaches a maximum width of only $1.2 \mathrm{~mm}$ at about the $6^{\text {th }}$ thecal pair and becomes septate at $7^{\text {th }}$ pair. As Goldman \& Bergström (1997, p. 993) noted, it appears to belong to $S$. putillus (Hall).

The present rhabdosomes are considerably shorter and also narrower than the $2.5 \mathrm{~mm}$ wide rhabdosomes of Styracograptus tubuliferus (Lapworth), described by Elles \& Wood (1906) and refigured recently by Riva \& Ketner (1989, fig. 10). The maximum width of the Nevadan specimens, however, is attained by $6^{\text {th }}$ to $10^{\text {th }}$ thecal pair, while British specimens attain their maximum width after some $30 \mathrm{~mm}$. The characteristic tubular nematularium is present in our specimens but no parasicula was recorded, even in the most mature ones. S. mississippiensis differs from S. putillus (Hall; = C. ulrichi Ruedemann, 1908, and possibly also C. chiai Mu, 1949) in that the former is somewhat wider (1.6-1.8 $\mathrm{mm} v \mathrm{~s}$ $1.2-1.5 \mathrm{~mm})$, has more nearly vertical supragenicular walls compared to the more outwardly inclined thecae of the latter, and is aseptate ( $S$. putillus has a complete median septum that arises variably between the $3^{\text {rd }}$ and $10^{\text {th }}$ pair) and in the presence of the nematularium. Compared to $C$. hastatus T.S. Hall, the present species lacks any basal spines except for virgella, which is considerably shorter than that of $C$. hastatus. It also differs from C. hastatus by lesser 2TRD of the initial thecae and lesser distal width of the rhabdosome.

Styracograptus tatianae (Keller, 1956)

Figures 21H, I, O, R-U, 22C, G, I, J, N, Table 18

1956 Climacograptus tatianae n. sp.; Keller (in Obut et al.), pp. 89, 90, figs 25, 26.

1980 Climacograptus tatianae Keller, 1956. - Koren' (in Apollonov et al.), pp. 139, 140, pl. 39, figs 6, 8, 9; text-fig. 40a-c.

1984 Climacograptus tatianae Keller. - Li, p. 170, pl. 6, figs 5,6 . 
Table 18. Styracograptus tatianae. Dimensions of illustrated specimens (in mm).

\begin{tabular}{|c|c|c|c|c|c|c|c|c|c|}
\hline \multirow{2}{*}{\multicolumn{2}{|c|}{ Specimen USNM Text-figure }} & \multicolumn{4}{|c|}{ W } & \multicolumn{4}{|c|}{ 2TRD } \\
\hline & & th1 & th5 & th10 & dist. max & th2 & th5 & th10 & dist. th \\
\hline 542820 & 210 & 0.6 & 0.8 & 0.95 & $>1.05$ & 1.35 & 1.7 & 1.85 & 1.85 \\
\hline 542732 & $21 \mathrm{H}, 22 \mathrm{C}$ & 0.65 & 0.95 & - & - & $?$ & 1.75 & - & - \\
\hline 542752 & $21 \mathrm{R}, 22 \mathrm{~N}$ & 0.65 & 1.05 & - & - & 1.25 & 1.45 & - & - \\
\hline 542736 & $21 \mathrm{~S}, 22 \mathrm{I}$ & 0.65 & 0.9 & 1.3 & 1.3 & 1.35 & 1.6 & 1.6 & 1.6 \\
\hline 542836 & $21 \mathrm{U}, 22 \mathrm{G}$ & 0.7 & 0.85 & - & - & 1.45 & 1.6 & - & - \\
\hline 542788 & $21 \mathrm{~T}, 22 \mathrm{~J}$ & 0.6 & 0.9 & 1.05 & 1.1 & 1.65 & 1.7 & 1.75 & 1.9 \\
\hline
\end{tabular}

1984 Climacograptus cf. miserabilis Elles \& Wood. - Li, p. 169 , pl. 6, fig. 4 .

1993 Climacograptus tatianae Keller. - Ge (in Mu et al.), p. 180 , pl. 31, fig. 12; pl. 32, figs $18,19$.

2005a Climacograptus tatianae Keller, 1956. - Chen et al., pp. 248, 249, text-fig. 5A, L, M, S, V, Y, BB.

Material and stratigraphical range. - More than 50 flattened specimens of this species (18 measured in detail) came from black shales and brown calcareous mudstones of the pacificus Zone of the Vinini Creek section and one measurable specimen also from Martin Ridge section. Rare occurrence extends down to the topmost ornatus Zone and up to the lower extraordinarius Zone. The species reappears as a Lazarus taxon in the persculptus Zone.

Description. - Aseptate, slender rhabdosome up to $22 \mathrm{~mm}$ long. Sicula ca $1.2 \mathrm{~mm}$ long, $0.15-0.25 \mathrm{~mm}$ wide at aperture and furnished with prominent virgella slightly deflected across sicula aperture, then straight and up to $10 \mathrm{~mm}$ long in some rhabdosomes. The first theca grows down to just below the sicular aperture before turning upwards. Th1 $1^{1}$ and th $1^{2}$ grew upward for $0.45-0.6 \mathrm{~mm}$ and $0.55-0.75 \mathrm{~mm}$, respectively (Table 18 ). Th $1^{1}$ ventral wall convex and th $1^{2}$ straight, producing blunt, somewhat asymmetrical proximal end. Rhabdosome widens gradually from $0.4-0.7 \mathrm{~mm}$ at first thecal pair, through $0.7-1.0 \mathrm{~mm}$ at th5, to $0.8-1.2 \mathrm{~mm}$ at th10. Maximum width 0.95-1.4 mm at distal end of mature rhabdosomes. Distinctive crossbars and prominent nema pressed through in several specimens. Climacograptid thecae with sharp to moderately rounded genicula, $0.55-0.65 \mathrm{~mm}$ long, slightly inclined supragenicular walls and $c a 0.25-0.3 \mathrm{~mm}$ wide, sub-semicircular apertural excavations. Some immature, thin-walled rhabdosomes exhibit fuselli. 2TRD: $1.25-1.6 \mathrm{~mm}$ at th2, $1.5-1.7 \mathrm{~mm}$ at th5, slowly increases through $1.6-1.75 \mathrm{~mm}$ at th10 to $1.6-1.9 \mathrm{~mm}$ in the most distal part of the rhabdosome.

Remarks. - Styracograptus tatianae is readily distinguishable by its aseptate, gently widening rhabdosome with well-developed cross-bars and blunt, asymmetrical proximal end with slightly U-shaped th $1^{1}$, and long virgella, commonly somewhat deflected over sicular aperture. The sicula is not exposed below th $1^{2}$, which is also consistent with typical climacograptid early astogeny of Pattern D. Our rhabdosomes are closely comparable with those described and figured by Keller (1965, text-fig. 25). Specimen USNM 542777 (Fig. 21G), which considerably widens from $0.55 \mathrm{~mm}$ at first thecal pair to $1.35 \mathrm{~mm}$ at th10, was designated Styracograptus cf. tatianae since its other parameters match those measured in typical $S$. tatianae.

Styracograptus? sp.

Figures 21K, 22K

Material and stratigraphical range. - Single flattened rhabdosome preserved in brown calcareous mudstone from the pacificus Zone, at $18.00 \mathrm{~m}$ of the Vinini Creek section.

Description. Rhabdosome $20.5 \mathrm{~mm}$ long, $1.2 \mathrm{~mm}$ wide, parallel-sided beginning with $\mathrm{ca} 10$ thecal pairs. Proximal end asymmetrical, $0.8 \mathrm{~mm}$ wide at first thecal pair. Th $1^{1}$ grew down the sicular aperture before it turned upwards for $1.05 \mathrm{~mm}$. Virgella short. Thecae glyptograptid with

Figure 22. A, B, E, H, M - Styracograptus mississippiensis Ruedemann, 1908: A - USNM 542660, level 4.40 m; B - USNM 542749, level MR 112.8 m; E - USNM 542729, level 4.40 m; H - USNM 542740, level MR 95.00 m; M - USNM 542685b, level 7.65 m. • C, G, I, J, N - Styracograptus tatianae Keller, 1956: C - USNM 542732, level 9.80 m; G - USNM 542836, level 18.80 m; I - USNM 542736, level 18.80 m; J - USNM 542788, level 18.80 m; N - USNM 542752, level MR 96.13 m. • D, F, L - Climacograptus hastatus T.S. Hall, 1902: D - USNM 542666, level 6.10 m; F - USNM 542826, level 9.20 m; L - USNM 542754, level MR 96.13 m. • K - Styracograptus sp.: USNM 542785, level 18.00 m. • USNM 542660, 542666, 542685b, 542729, 542740, 542752 and 542754 from the ornatus Biozone, USNM 542732, 542736, 542749, 542785, 542788, 542826 and 542836 from the pacificus Biozone. USNM 542660, 542666, 542685b, 542729, 542732, 542736, 542785, 542788, 542826 and 542836 from the Vinini Creek section, USNM 542740, 542749, 542752 and 542754 from the Martin Ridge section. All figures $\times 6$, except A, F × 10. Scale bars equal 1 mm. 
Petr Štorch et al. • Uppermost Ordovician graptolites of north-central Nevada
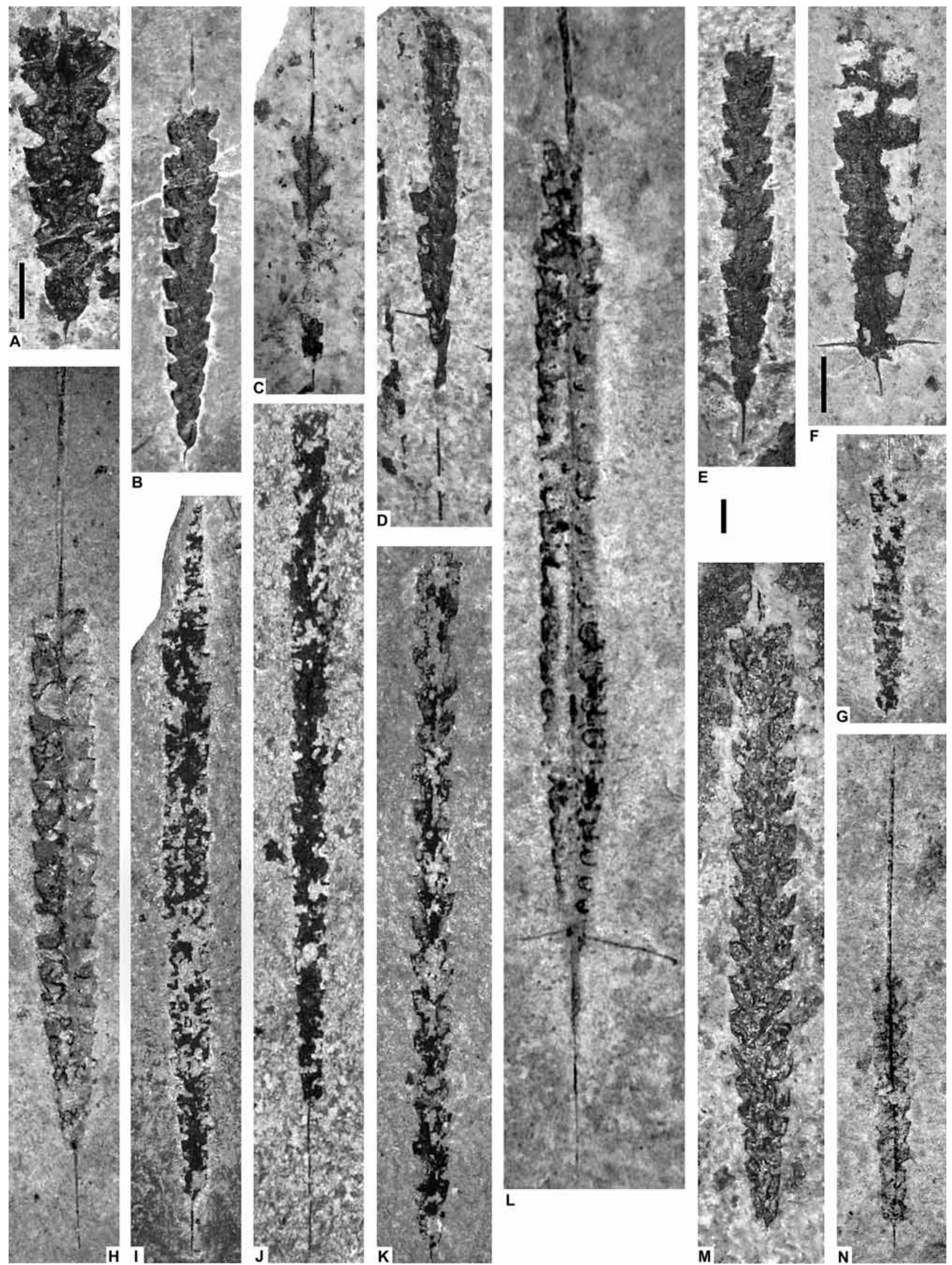
flowing geniculum. $2 \mathrm{TRD}_{2}: 1.85$, th5: 1.95 and $2.05-2.2$ distally. No trace of median septum observed.

Remarks. - Present form is distinguished from associated and superficially similar S. tatianae by its slightly wider, almost parallel-sided rhabdosome, short virgella, asymmetrical proximal end with downward growing prothecal part of thl ${ }^{1}$, and more widely spaced glyptograptid thecae with flowing geniculum. Median septum is missing in both taxa. Proposed generic assignment of present form is provisional since the early astogeny is also compatible with the normalograptid pattern $\mathrm{H}$ proximal structure in the downward growing part of th $1^{1}$ and, evidently, the lack of basal spines in addition to the virgella. The lack of a median septum, however, strongly suggests that this form is not a normalograptid.

\section{Genus Appendispinograptus Li Zhi-ming \& Li Da-qing, 1985, emend. Chen et al., 2005a}

Type species. - Climacograptus venustus Hsu, 1959, p. 346, pl. 1, figs 1-6, 13; by original designation.

\section{Appendispinograptus longispinus (T.S. Hall, 1902)}

Figures 23B, F, H, K, M, Q, R, T, 24M-O, Table 19

1902 Climacograptus bicornis var. longispina; T.S. Hall, p. 54 , pl. 12, figs 8,9 .

1963 Climacograptus bicornis var. longispina T.S. Hall. Ross \& Berry, p. 118, pl. 8, fig. 13.

1963 Climacograptus hvalross n. sp. - Ross \& Berry, pp. 124, 125, pl. 8, figs 19, 26, 27.

1966 Climacograptus bicornis subspecies longispina T.S. Hall. - Berry, pp. 437-439, pl. 49, figs 3, 4.

1974 Climacograptus longispinus longispinus T.S. Hall, 1902. - Riva, pp. 111-114, pl. 7, figs 1-6; text-figs 2a-g, 3, 4a-f.

1974 Climacograptus bicornis longispinus T.S. Hall. Obut \& Sobolevskaya, p. 98, pl. 41, fig. 2.
1974 Climacograptus crassispinus; Obut \& Sobolevskaya, p. 101, pl. 41, figs 5-7.

1974 Climacograptus lamellicornis; Sobolevskaya (in Obut ed.), p. 65, pl. 3, figs 3, 4 .

1983 Climacograptus longispinus longispinus T.S. Hall 1902. - Koren' \& Sobolevskaya (in Koren' et al.), pp. 117-123 (partim), pl. 31, figs 4-7; pl. 32, figs $1-7$; pl. 33, figs $1-3$ (non $4-5$ ), text-fig. 40, 41 (non 42).

1993 Climacograptus longispinus T.S. Hall. - Ge (in Mu et al.), pp. 174, 175 (partim), pl. 35; figs 17, ?18; (non pl. 34, fig. 2).

Material and stratigraphical range. - The species, confined to the ornatus Zone, is equally common in the Vinini Creek and Martin Ridge sections. Of more than 40 flattened rhabdosomes from limestones, lime-mudstones and mudstones, 11 were measured in detail.

Description. - Large aseptate rhabdosome $>50 \mathrm{~mm}$ long. Proximal part with large basal spines $10-16 \mathrm{~mm}$ long, $0.35 \mathrm{~mm}$ wide in mature rhabdosomes, forming broad, downward directed U-shaped arch. Primary structures observed in immature specimens indicate that spines on th $1^{1}$ and $1^{2}$ are basal. During astogeny up to three secondary (parathecal) tubes grew down from aperture of early thecae along upper side of basal spines and, in gerontic specimens, entirely obscured proximal two-three thecal pairs. Rhabdosome axially twisted in proximal $10 \mathrm{~mm}$, producing distally scalariform orientation in most specimens. Immature rhabdosomes without parathecae $0.65-0.8 \mathrm{~mm}$ wide at th1, th5: $1.0-1.3 \mathrm{~mm}$, th10: $1.6-2.0 \mathrm{~mm}$ (scalariform aspect) and thereafter very gradually widening to $2.0-2.7 \mathrm{~mm}$. Thecae climacograptid with sharp geniculum; supragenicular walls almost parallel-sided, $0.55-0.65 \mathrm{~mm}$ long in proximal thecae and $0.8-0.9 \mathrm{~mm}$ long in distal thecae. $2 \mathrm{TRD}_{2}$ : $1.2-1.5 \mathrm{~mm}$, th5: $1.6-1.85 \mathrm{~mm}$, th10: $2.0-2.15 \mathrm{~mm}$ and 2.3-2.65 $\mathrm{mm}$ at distal maximum (i.e., $c a 8$ in $10 \mathrm{~mm}$ ).

Remarks. - Present rhabdosomes correspond well with Riva's (1974) detailed description of the species. His study

Table 19. Appendispinograptus longispinus. Dimensions of illustrated specimens (in mm).

\begin{tabular}{|c|c|c|c|c|c|c|c|c|c|c|}
\hline \multirow{2}{*}{\multicolumn{2}{|c|}{ Specimen USNM Text-figure }} & \multirow{2}{*}{$\mathrm{L}$ basal spines } & \multicolumn{4}{|c|}{ W } & \multicolumn{4}{|c|}{ 2TRD } \\
\hline & & & $\min W /$ th & th5 & th 10 & dist. max & th2 & th5 & th10 & dist. th \\
\hline 542756 & $23 \mathrm{~B}, 24 \mathrm{M}$ & $>15.7$ & $0.95 / 3$ & 1.15 & 2.0 & 2.55 & $?$ & 1.75 & 2.1 & 2.65 \\
\hline 542679 & $23 \mathrm{~F}$ & $>13.0$ & $0.95 / 3$ & 1.3 & 2.0 & 2.55 & $?$ & $?$ & 2.15 & $?$ \\
\hline 542674 & $23 \mathrm{H}$ & $>10.0$ & $0.7 / 2$ & 1.2 & 1.6 & $?$ & 1.3 & 1.75 & $?$ & $?$ \\
\hline $542753 b$ & $23 \mathrm{M}$ & 3.85 & $0.7 / 1$ & 1.15 & 1.35 & 1.85 & 1.2 & 1.7 & 1.85 & - \\
\hline 542741 & $23 \mathrm{Q}$ & 4.8 & $0.7 / 1$ & 1.05 & 1.6 & 2.0 & $?$ & 1.85 & 2.1 & 2.3 \\
\hline 542854 & $23 \mathrm{~T}, 24 \mathrm{~N}$ & 6.0 & $0.8 / 1$ & 1.3 & 1.6 & 1.85 & 1.2 & 1.6 & 1.9 & - \\
\hline 530548 & $24 \mathrm{O}$ & 10.0 & $1.05 / \sim 4$ & 1.2 & 1.9 & 2.7 & $?$ & 1.6 & 2.0 & $?$ \\
\hline
\end{tabular}


of astogenetic development, based upon large collections from the Toquima Range of Nevada, shows a distinctive growth plan along with considerable variation in secondary tubular extensions of the early thecae that grew along the dorsal side of the basal spines and so appear to enlarge the whole base of the rhabdosome (see also Mitchell et al. 2007c). The basal structures observed in specimens of A. longispinus hsuei (Sobolevskaya, 1969) figured by Koren' \& Sobolevskaya (in Koren' et al., 1983, pl. 33, figs 4, 5; text-fig. 42 a, b, v) and A. venustus (Hsu, 1959), however, do not represent extreme varieties of the secondary structures of $A$. longispinus and may be regarded as species-diagnostic features. In contrast to A. supernus and A. leptothecalis, the rhabdosome of A. longispinus is strongly twisted along its axis so that the distal thecae face perpendicular to the growth plane of the basal spines. A few mature, axially twisted rhabdosomes among our collections exhibit small tubes (parasiculae) at lower side of basal spines - a feature typical of Appendispinograptus longispinus hvalross (Ross \& Berry, 1963) according to Riva (1974), but otherwise do not differ in any significant degree. Thus, the timing and extent of development of parathecae (extensions of the thecal tubes, which consequently typically lie on the dorsal side of the spines) and parasiculae (tubes that arose from the aperture of the sicula and so typically were attached to the ventral side of the spines) appears to vary among specimens of A. longispinus.

Koren' et al. (1983) suggested that A. longispinus hvalross represents just an early stage in the astogenetic development of $A$. longispinus. Intraspecific variation in proximal morphology and rhabdosome twisting of A. longispinus is evident - some of our specimens of A. longispinus exhibit slightly delayed and/or suppressed growth of secondary tubes. Considering the new material from densely sampled reference sections at Vinini Creek and Martin Ridge we agree with Koren' et al. (1983) and regard A. longispinus hvalross (Ross \& Berry) as a junior synonym of A. longispinus longispinus (T.S. Hall).

Some mature rhabdosomes assigned to A. longispinus hvalross by Riva (1974, figs 6p, 7f, h), however, do not exhibit rhabdosome twisting typical of $A$. longispinus and rather resemble mature specimens of Appendispinograptus supernus (Elles \& Wood) figured by Williams (1982, text-fig. $8 \mathrm{~m}$; pl. 3, figs $4,7,8$ ). Their other characters, such as a more slender rhabdosome, also are shared with A. supernus (Elles \& Wood).

Appendispinograptus supernus (Elles \& Wood, 1906) Figures 23A, C-E, ?G, I, J, O, S, 24A-F, H-J, Table 20

1906 Climacograptus supernus sp. nov.; Elles \& Wood, pp. 196-197, pl. 26, fig, 11a-d; text-fig. 127a-c (non d).

1963 Climacograptus bellulus; Mu \& Zhang, text-fig. 10f.
1970 Climacograptus supernus Elles \& Wood. - Toghill, p. 22, pl. 11, figs 5, 6, 8-10.

1970 Climacograptus hvalross Ross \& Berry. - Toghill, p. 22, pl. 2, figs $1-4,7$.

1974 Climacograptus longispinus supernus Elles \& Wood, 1906. - Riva, pp. 120, 123, 125; text-fig. 8a-q.

1974 Climacograptus longispinus hvalross Ross \& Berry, 1963. - Riva, pp. 114, 117-119 (partim), text-fig. 6g, $\mathrm{p}$ (non $\mathrm{h}-\mathrm{O}$ and ?a-f); text-fig 7f, h (non a-e, ?g, i, j).

1978 Climacograptus hubeiensis Ge (MS).- Ye, p. 458, pl. 172, fig. 14.

1980 Climacograptus longispinus supernus Elles \& Wood, 1906. - Koren', Mikhaylova \& Tzai (in Apollonov et al.), pp. 135-137, pl. 38, figs 1-6, text-fig 38а-ж.

1983 Climacograptus longispinus supernus Elles \& Wood, 1906. - Koren' \& Sobolevskaya (in Koren' et al.), pp. 126-128 (partim), pl. 35, figs 1-11; text-fig. 44 (non pl. 36, figs 1-5; text-fig. 45).

1983 Climacograptus leptothecalis Mu \& Ge. - Wang (in Wang et al.), pl. 2, fig. 4.

1984 Climacograptus supernus Elles \& Wood. - Mu \& Lin, p. 57, pl. 4, figs 4,6.

1984 Climacograptus tenuicornis Li (sp. nov.); Li, p. 176, pl. 9, figs 4,5,7.

1984 Climacograptus bellulus Mu \& Zhang. - Li, p. 173, pl. 6, fig. 7; pl. 7, fig. 10; pl. 9, figs 9, 15.

1984 Climacograptus bellulus wannanensis Li (subsp. n.); Li, p. 173, pl. 7, figs 11-15; text-fig. 6c.

1984 Climacograptus supernus fortispinus Li (subsp. nov.); Li, p. 175, pl. 8, figs 9, 16; text-fig 8a.

1987 Climacograptus supernus Elles \& Wood, 1906. Melchin, pp. 196, 198; pl. 1, figs 9-13.

1989 Appendispinograptus supernus (Elles \& Wood, 1906). - Riva \& Ketner, p. 85, text-fig. 9g-j.

1993 Climacograptus supernus Elles \& Wood. - Ge (in Mu et al.), pp. 178, 179, pl. 34, fig. 10; pl. 36, fig. 17; pl. 38, figs 1-12.

1993 Climacograptus supernus longus $\mathrm{Ge}, 1983$ - - Ge (in Mu et al.), pp. 179, 180, pl. 32, fig. 12; pl. 40, figs $1-4,13$.

1993 Climacograptus bellulus Mu \& Zhang. - Ge (in Mu et al.), pp. 156, 157, pl. 31, fig. 5; pl. 36, figs 14, 15.

1993 Climacograptus hubeiensis Ge. - Ge (in $\mathrm{Mu}$ et al.), p. 173, pl. 32, figs 4-9, 11.

1993 Climacograptus minor Ge. - Ge (in Mu et al.), pp. 175, 176, pl. 38, figs 14, 15.

1993 Climacograptus notabilis sp. nov.; Ge (in Mu et al.), p. 177, pl. 40, fig. 11.

2002 Appendispinograptus hvalross (Ross \& Berry). - Mu et al., pp. 670, 671, pl. 185, fig. 8.

2002 Appendispinograptus supernus (Elles \& Wood). Mu et al., p. 673, pl. 186, figs 2, 3.

2005a Appendispinograptus supernus (Elles \& Wood, 1906). -Chen et al., pp. 249, 250, text-fig. 5E, X, FF. 
Table 20. Appendispinograptus supernus. Dimensions of illustrated specimens (in mm).

\begin{tabular}{|c|c|c|c|c|c|c|c|c|c|c|}
\hline \multirow{2}{*}{\multicolumn{2}{|c|}{ Specimen USNM Text-figure }} & \multirow{2}{*}{ L basal spines } & \multicolumn{4}{|c|}{$\mathrm{W}$} & \multicolumn{4}{|c|}{ 2TRD } \\
\hline & & & $\min \mathrm{W} / \mathrm{th} 2$ & th5 & th10 & dist. max & th2 & th5 & th10 & dist. th \\
\hline 542802 & $23 \mathrm{D}, 24 \mathrm{~A}$ & 2.4 & 0.55 & 0.85 & $?$ & - & 1.25 & 1.4 & - & - \\
\hline 542699 & $23 \mathrm{E}, 24 \mathrm{C}$ & 1.5 & 0.7 & 0.95 & 1.5 & 1.55 & 1.3 & 1.65 & 1.35 & 1.45 \\
\hline 542803 & $23 \mathrm{I}, 24 \mathrm{H}$ & 1.3 & 0.6 & 0.85 & 1.35 & 1.45 & 1.45 & 1.45 & 1.5 & 1.7 \\
\hline 542775 & $23 \mathrm{~J}$ & 1.1 & 0.63 & 1.0 & 1.5 & - & 1.45 & 1.55 & 1.65 & - \\
\hline 542861 & $23 \mathrm{~S}, 24 \mathrm{I}$ & 1.6 & 0.52 & 0.8 & 0.95 & - & 1.45 & 1.6 & - & - \\
\hline 542792 & $24 \mathrm{~B}$ & 2.55 & 0.62 & 0.9 & 1.35 & - & 1.25 & 1.3 & - & - \\
\hline 542675 & $24 \mathrm{~F}$ & 1.25 & 0.5 & 0.8 & - & - & 1.1 & - & - & - \\
\hline 542747 & $24 \mathrm{~J}$ & 1.2 & 0.58 & 0.95 & 1.25 & 1.5 & 1.15 & 1.35 & 1.5 & - \\
\hline
\end{tabular}

Material and stratigraphical range. - Common species of the pacificus Zone at Vinini Creek and Martin Ridge sections, rare in the extraordinarius Zone at Vinini Creek. More than 50 flattened specimens preserved in both pale- and dark-coloured lime-mudstones, brown mudstones and black shales (26 specimens measured in detail).

Description. - Present rhabdosomes attain $>27 \mathrm{~mm}$ in length. Slightly asymmetric proximal end nearly rectangular, 0.55-0.7 mm wide at the level of the first thecal apertures. Th $1^{1}$ and th $1^{2}$ bear prominent genicular spines (at least 3 $\mathrm{mm}$ long in mature rhabdosomes) that form open U-shaped arch. Slender, 0.1-0.6 mm long virgella markedly deflexed over concave sicular aperture. In some mature specimens, short parasiculae developed along the lower side of spines. The rhabdosome exhibits no or only slight axial torsion. It narrows slightly at the second thecal pair $(0.5-0.65 \mathrm{~mm})$ before it gradually widens, th5: $0.7-1.0 \mathrm{~mm}$, th10: $1.0-1.5 \mathrm{~mm}$, maximum: $1.1-1.6 \mathrm{~mm}$, attained by $14^{\text {th }}$ to $19^{\text {th }}$ theca. The thecae climacograptid, with semicircular excavation, sharp geniculum and nearly parallel-sided supragenicular wall that, in some specimens, is slightly outwardly inclined $\left(1-4^{\circ}\right)$. Thecal apertures $c a 0.15 \mathrm{~mm}$ wide proximally and $0.2 \mathrm{~mm}$ wide distally. Supragenicular thecal walls $0.5-0.65 \mathrm{~mm}$ long throughout the rhabdosome. $2 \mathrm{TRD}_{2}$ : 1.1-1.45 mm; th10: $1.45-1.8 \mathrm{~mm}$. Distal thecae number 11-13.5 in $10 \mathrm{~mm}$ (2TRD $1.45-1.8 \mathrm{~mm}$ ). Strongly thickened septal cross-bars evident in some specimens and thin nema often projected distally well beyond the rhabdosome.
Remarks. - Immature rhabdosomes with small spines and without any parasicular tubes (basal membranes) have been described as new species and subspecies by Li (1984). Their principal dimensions and parameters such as rhabdosome width, thecal form and spacing are well within the range measured in cosmopolitan A. supernus. Distinct variability in basal spines and associated parasiculae, recorded by Williams (1982) in A. supernus, has been observed, though to a lesser degree in our material. This suggests that some rhabdosomes assigned to A. longispinus hvalross by Riva (1974) actually belong to the present species. Our collections include some specimens that, although otherwise similar to typical A. supernus specimens, resemble Appendispinograptus hubeiensis Ge (in Ye, 1978) in that they exhibit strongly thickened thecal margins and deeper, introverted apertures (e.g., Fig. 24D, E). The type material of $A$. hubeiensis (recently examined by CEM) likewise falls entirely within the range of colony form and dimensions of $A$. supernus. Among the specimens included in A. hubeiensis by $\mathrm{Ge}$ and later by $\mathrm{Mu}$ et al. (1993) some also possess apertural features more typical of $A$. supernus. Thus, in contrast to Chen et al. (2000), we conclude that $A$. hubeiensis is a junior synonym of $A$. supernus. On the other hand, A. hanyuanensis Ge, 1993 (in Mu et al.), which Chen et al. (2000) placed in synonymy with A. hubeiensis, appears to be a distinct species that differs from $A$. supernus in being somewhat broader beyond the proximal end (width at th5 $1.1-1.4 \mathrm{~mm}$ and $1.5-1.7 \mathrm{~mm}$ at th10) and with larger thecae $\left(2 \mathrm{TRD}_{5}: 1.6-2.0 \mathrm{~mm}\right.$, th10:

Figure 23. A, C-E, ?G, I, J, O, S - Appendispinograptus supernus (Elles \& Wood, 1906): A - USNM 542807, level 17.90 m; C - USNM 542698, level $10.80 \mathrm{~m}$; D - USNM 542802, level $10.30 \mathrm{~m}$; E - USNM 542699, level $11.70 \mathrm{~m}$; ?G - USNM 542837, level 11.70 m; I - USNM 542803, level MR 105.20 m; J - USNM 542775, level MR 105.20 m; O - 542792, level 10.30 m; S - USNM 542861, level 10.30 m. • B, F, H, K, M, Q, R, T - Appendispinograptus longispinus (T.S. Hall, 1902): B - USNM 542756, level MR 96.13 m; F - USNM 542679, level 7.50 m; H - USNM 542674, level 9.20 m; K - USNM 542753a, M - USNM 542753b, level MR 96.13 m; Q - USNM 542741, level MR 95.00 m; R - USNM 542786, level 9.20 m; T - USNM 542854, level MR 96.13 m. • L, ?P - Appendispinograptus leptothecalis (Mu \& Ge, 1982): L - USNM 542787, level 18.00 m; ?P - USNM 542809, level $17.80 \mathrm{~m} . \bullet \mathrm{N}$ - Appendispinograptus sp.: USNM 542665, level $18.00 \mathrm{~m}$. USNM 542679, 542741, 542753a, b, 542756 and 542854 from the ornatus Biozone, USNM 542665, 542674, 542698, 542699, 542775, 542786, 542787, 542792, 542802, 542803, 542807, 542809, 542837 and 542861 from the pacificus Biozone. A, C-H, L, N-R from the Vinini Creek section, B, F, I-K, M, Q, T from the Martin Ridge section. All figures $\times 6$ (common scale bar equals $1 \mathrm{~mm}$ ), except $\mathrm{B}, \mathrm{F} \times 3$ (two respective scale bars equal $1 \mathrm{~mm}$ ). 
Petr Štorch et al. • Uppermost Ordovician graptolites of north-central Nevada

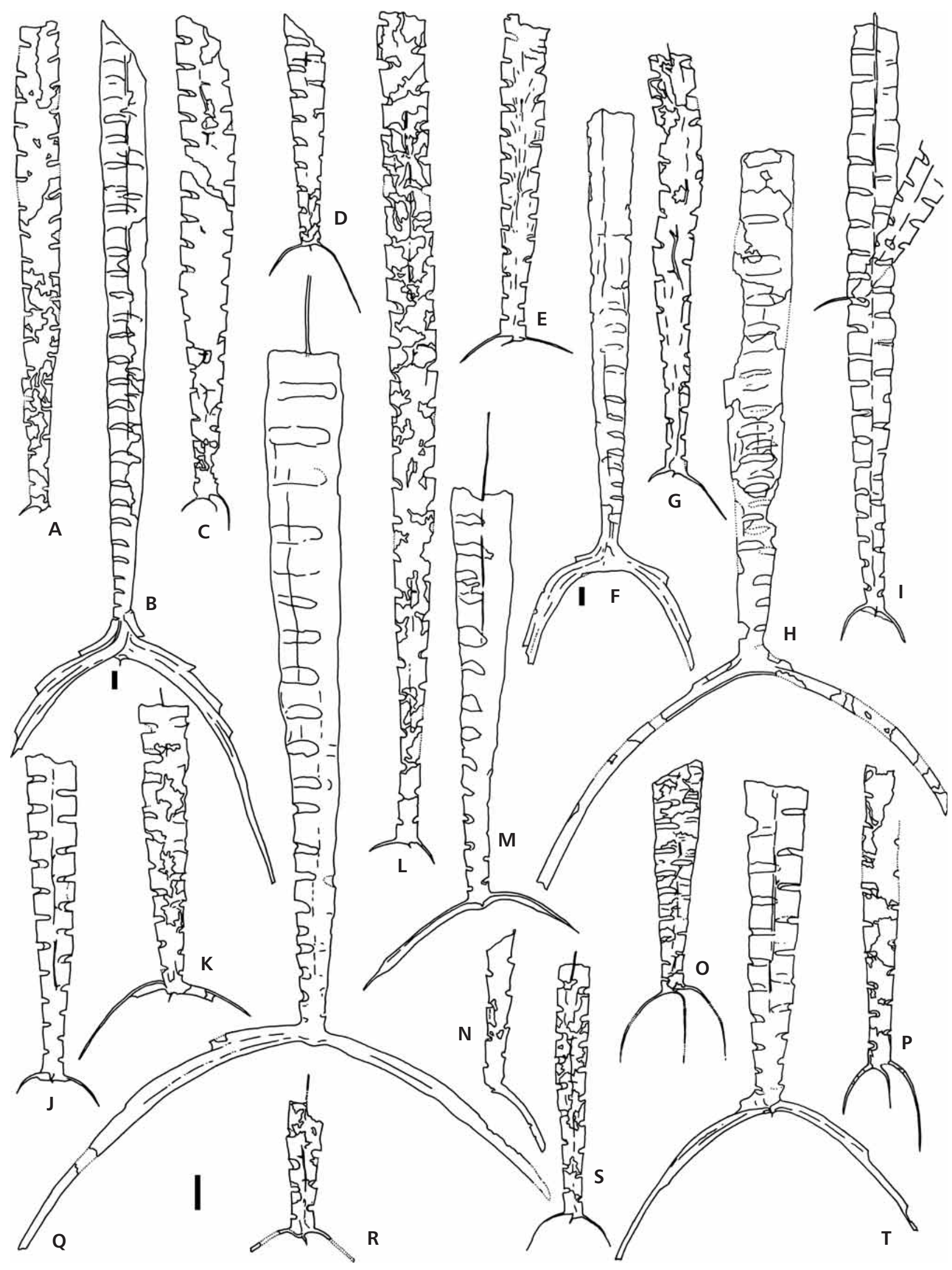


1.9-2.2 mm). In addition A. hanyuanensis has robust nema, crossbars in the proximal end, up to about th10, where colonies become septate. Finally, the nema in that species is relatively stout and tapers abruptly to a sharp point $\mathrm{ca} 1 \mathrm{~mm}$ from the distal end of the colony.

\section{Appendispinograptus leptothecalis (Mu \& Ge, 1982)} Figures 23L, ?P, 24?G, L

1982 Climacograptus leptothecalis; $\mathrm{Mu} \& \mathrm{Ge}$ (in $\mathrm{Fu}$ ), p. 456 , pl. 289 , fig. 7 .

non 1983 Climacograptus leptothecalis Mu \& Ge. - Wang (in Wang et al.), pl. 2, fig. 4.

1983 Climacograptus leptothecalis angustus Wang. Wang (in Wang et al.), pl. 3, fig. 2.

1984 Climacograptus leptothecalis $\mathrm{Mu} \&$ Ge. - Li, p. 176, pl. 9, figs 11-14; text-fig. 8d.

1984 Climacograptus leptothecalis Mu \& Ge.-Ge, p. 251, pl. 3, fig. 12 .

1993 Climacograptus leptothecalis $\mathrm{Mu} \& \mathrm{Ge} .-\mathrm{Ge}$ (in $\mathrm{Mu}$ et al.), pp. 185, 186, pl. 39, figs 1-3, 5-19.

2005a Appendispinograptus leptothecalis (Mu \& Ge, 1982); Chen et al., pp. 250, 251, text-figs 5J, Z, EE, 7A, F.

Material and stratigraphical range. - 12 flattened specimens of this species ( 8 measured in detail) are from brown calcareous mudstones of the upper pacificus Zone of the Vinini Creek section. Rare and doubtful finds came from topmost ornatus Zone and the extraordinarius Zone.

Description. - The mature rhabdosome at least $30 \mathrm{~mm}$ long; $0.5-0.7 \mathrm{~mm}$ wide at th1, slightly narrower at th 2 and, after this bottleneck, widens gradually; th5: 0.65-0.9 mm, th10: 0.8-1.3 mm, maximum: $1.4-1.7 \mathrm{~mm}$. Basal spines that rise from th $1^{1}$ and $1^{2}$ genicula grow perpendicular to the rhabdosome before they turn down in form of an arch. Spines are robust but only 1.0-2.6 mm long, even in mature specimens. The sicula is fully covered except for concave aperture with short $(0.1-0.35 \mathrm{~mm})$, deflected virgella. No secondary membrane has been observed. Parallel-sided upward growing parts of the initial thecae are $0.5-0.55 \mathrm{~mm}$ and $0.5-0.65 \mathrm{~mm}$ high, respectively. The following thecae are of climacograptid type, with narrow apertural excavations $(0.2-0.25 \mathrm{~mm})$, sharp genicula and relatively long $(0.65-0.9 \mathrm{~mm})$ supragenicular walls, inclined at an angle of $1-7^{\circ}$ to the rhabdosome. Apertural excavations become $0.25-0.35 \mathrm{~mm}$ wide and supragenicular walls $0.7-0.85 \mathrm{~mm}$ long in distal thecae. $2 \mathrm{TRD}_{2}: 1.55-1.85 \mathrm{~mm}$, increases rapidly to th5: $1.9-2.2 \mathrm{~mm} ; 2.0-2.2 \mathrm{~mm}$ distally (9-10 thecae in $10 \mathrm{~mm}$ ).

Remarks. - Rhabdosomes herein assigned to A. leptothecalis are marked by narrow proximal end without parathecae or parasiculae, gradual but significant distal-ward increase in width, and rather long, widely spaced thecae with slightly outwardly inclined supragenicular wall and slightly asymmetrical, semicircular apertural excavation. Basal spines tend to be smaller that those in A. supernus. Both species share straight rhabdosome without the strong axial twisting typical of $A$. longispinus.

\section{Appendispinograptus sp.}

Figures 23N, 24K

Material and stratigraphical range. - Two incomplete, flattened rhabdosomes preserved in brown calcareous mudstone from the upper pacificus Zone of the Vinini Creek section.

Remarks. - Incomplete specimens exhibit narrow proximal end (0.6-0.65 $\mathrm{mm}$ at th1, $0.9 \mathrm{~mm}$ at th5), large and secondarily thickened basal spine(s), and $0.75-0.85 \mathrm{~mm}$ long supragenicular thecal walls that incline at $3-6^{\circ}$ to the rhabdosome axis. A combination of morphological parameters of the rhabdosome does not match any other appendispinograptid and limited material made its definitive taxonomic assignment impossible. Long and outwardly inclined supragenicular walls, combined with narrow proximal rhabdosome, are similar to A. leptothecalis whereas robust basal spines resemble $A$. longispinus. Present rhabdosomes are broken but appear not to exhibit the strong axial twisting typical of A. longispinus. Mature rhabdosomes of A. supernus may be furnished with rather long basal spines but can be easily discriminated by their shorter and less inclined thecae.

Figure 24. A-F, H-J - Appendispinograptus supernus (Elles \& Wood, 1906): A - USNM 542802, level 10.30 m; B - USNM 542792 , level 10.30 m; C-USNM 542699, level $11.70 \mathrm{~m}$; D - USNM 542698, level $10.80 \mathrm{~m}$; E - USNM 542807, level $17.90 \mathrm{~m}$; F - USNM 542675, level $18.00 \mathrm{~m}$; H - USNM 542803, level MR $105.0 \mathrm{~m}$; I - USNM 542861, level $10.30 \mathrm{~m}$; J - USNM 542747, level MR $112.8 \mathrm{~m}$. ? G, L - Appendispinograptus leptothecalis (Mu \& Ge, 1982): ?G - USNM 542809, level $17.80 \mathrm{~m}$; L - USNM 542787, level $18.00 \mathrm{~m}$. $\bullet$ K - Appendispinograptus sp., USNM 542665, level $18.00 \mathrm{~m}$. - M-O - Appendispinograptus longispinus (T.S. Hall, 1902): M - USNM 542756, level MR 96.13 m; N - USNM 542854, level MR 96.13 m; O - USNM 530548, level $7.65 \mathrm{~m}$. - USNM 530548, 542756 and 542854 from the ornatus Biozone, USNM 542665, 542675, 542698, 542699, 542747,542787 , 542792, 542802, 542803, 542807, 542809 and 542861 from the pacificus Biozone. USNM 530548, 542665, 542675, 542698, 542699, 542787, 542792, 542802, 542807, 542809 and 542861 from the Vinini Creek section, USNM 542747, 542756, 542803 and 542854 from the Martin Ridge section. Figures $\mathrm{H}, \mathrm{M}, \mathrm{O} \times 3$, figures $\mathrm{A}-\mathrm{E}, \mathrm{G}, \mathrm{I}-\mathrm{K}, \mathrm{N} \times 6$, figure $\mathrm{F} \times 10$. Scale bars equal $1 \mathrm{~mm}$. 
Petr Štorch et al. • Uppermost Ordovician graptolites of north-central Nevada
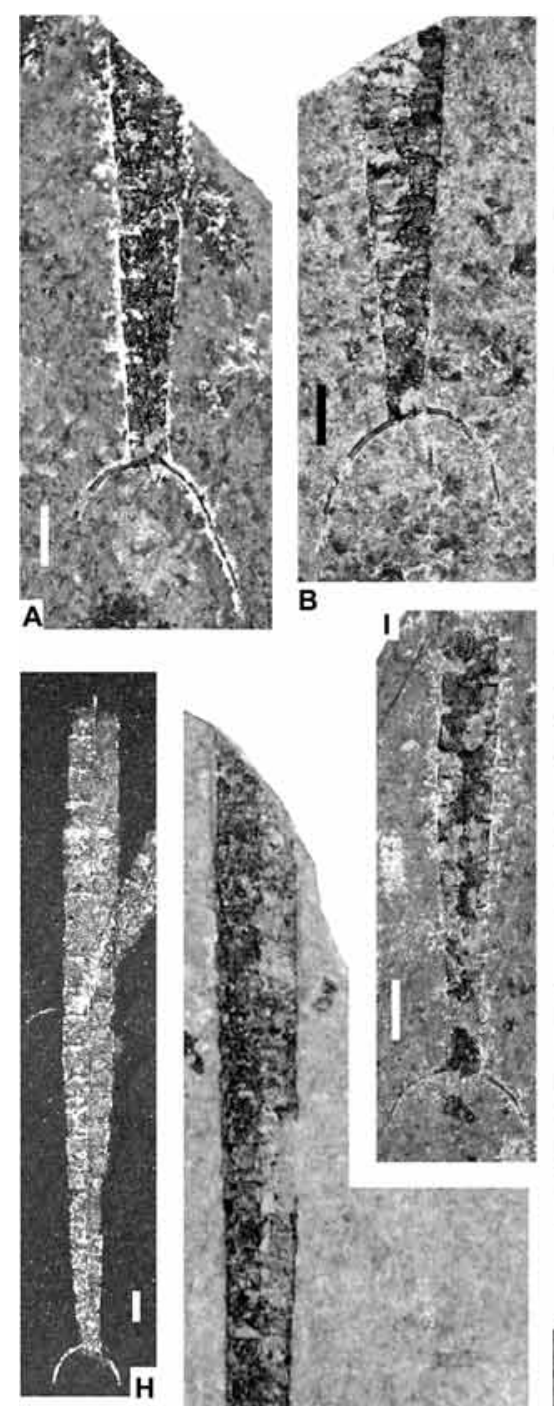

M

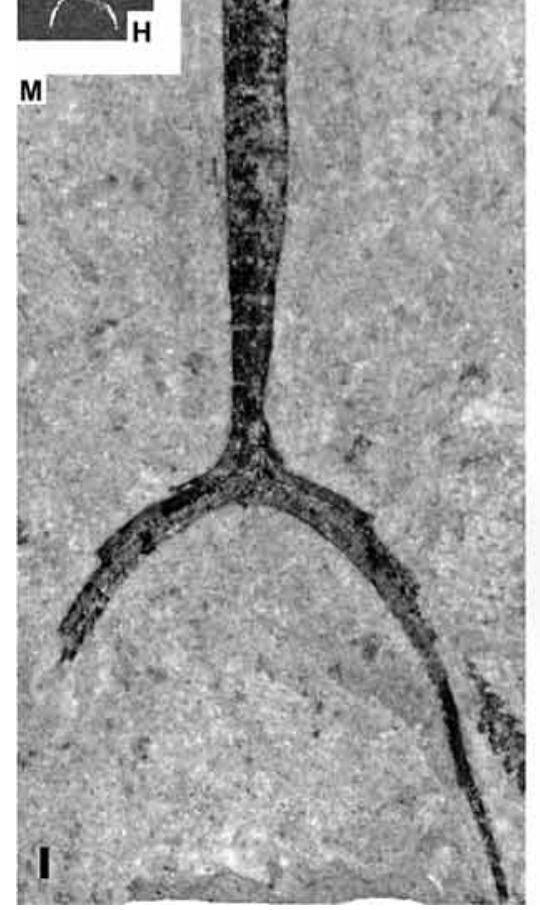

$$
\text { , }
$$
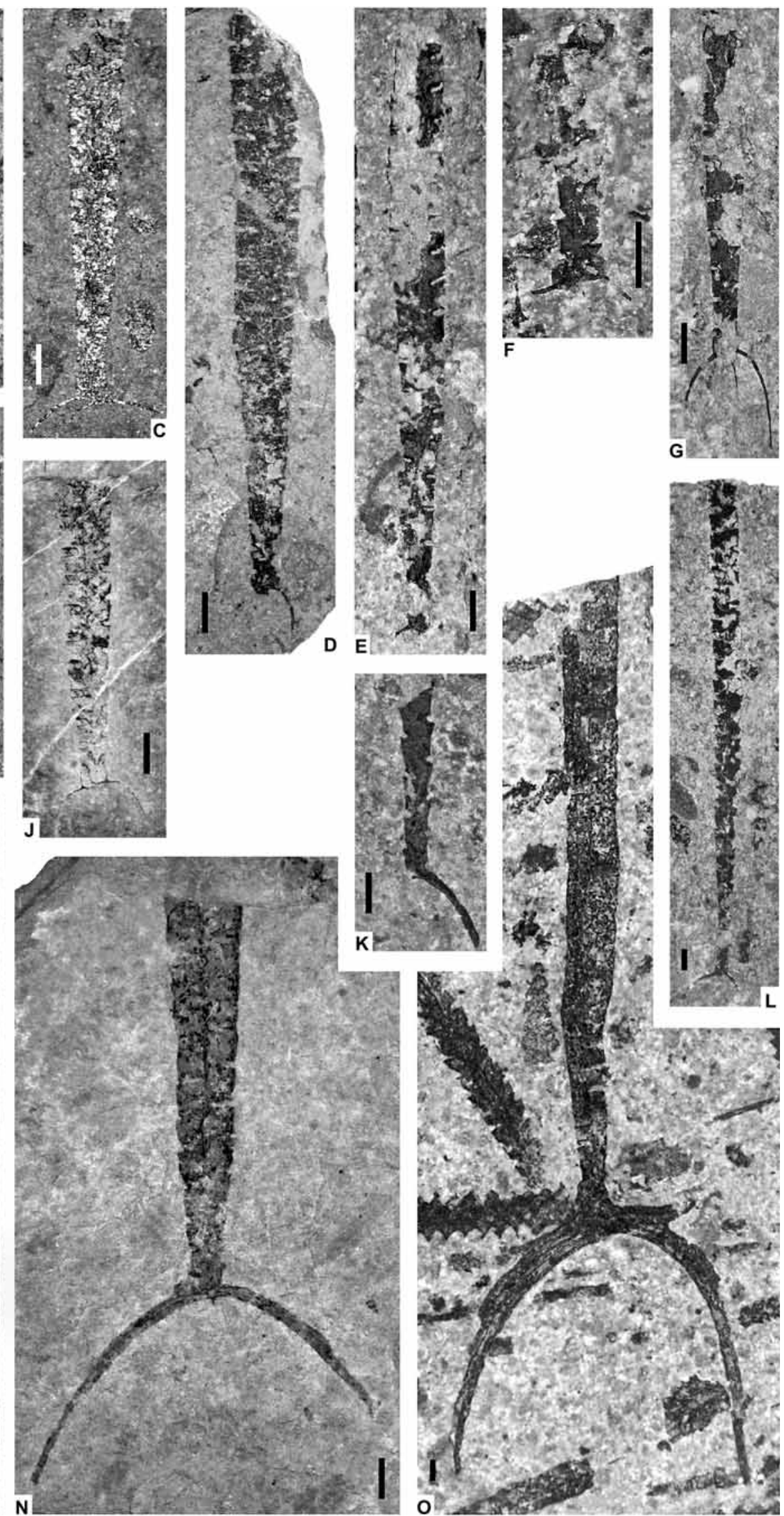
Infraorder Neograptina new

Diagnosis. - The Neograptina is the total clade comprising all species sharing a more recent common ancestor with Monograptus priodon than with Diplograptus pristis (i.e., the species on the branches arising from the right side of node 1 in Fig. 6 and all their descendents).

Remarks. - The Neograptina is the sister taxon to the Diplograptina. The earliest known member of this clade is the early Darriwilian species Undulograptus formosus. Basal members of the clade also include species of the genera Oelandograptus Mitchell, 1987 and Proclimacograptus Maletz, 1997. All of these graptolites possess a relatively narrow proximal end that lacks spines other than the virgella and exhibit a pattern $\mathrm{C}$ proximal structure with a highly reduced manubrium, strongly upwardly grown thecae and dicalycal th2 ${ }^{2}$ (see Mitchell 1987, 1990; Maletz 1997). Further simplification of this proximal structure led to the Pattern $\mathrm{H}$ astogeny that characterizes Normalograptus (see Mitchell 1987, Melchin \& Mitchell 1991, and Melchin 1998, for a description of these proximal structures). Currently the oldest known species of this genus is Normalograptus antiquus (Ge, 1990), which occurs in the mid Darriwilian Pterograptus elegans Zone in North China (Ge et al. 1990) and Baltoscandia (Maletz 1997).

During the Middle and Late Ordovician this clade is represented by a very conservative and species-poor lineage of Normalograptus species. This situation changed dramatically during the Hirnantian (Mitchell 1990, Melchin \& Mitchell 1991), when both morphological and taxonomic diversity began to expand dramatically in the group. All Silurian graptolites, including the Retiolitidae and Monograptidae are among the descendents of this conservative group, and thus lie within the Neograptina. Melchin (1998) proposed basic phylogenetic relationships among the major groups Silurian "diplograptids", but his analysis was based only on the distribution of characters of early astogeny and the operational taxonomic units were coarse groups of species united by their astogenetic patterns. Some further advances in our understanding of the phylogeny of these taxa have been presented in abstract form (Melchin et al. 2003, 2005), and a comprehensive phylogenetic analysis of these various groups and their ancestry within the Normalograptidae is currently under study. Present evidence suggests that both Normalograptus itself and the Normalograptidae, as currently defined, are paraphyletic (probably multiply so) and will require further subdivision (Melchin 1998).

Family Normalograptidae Štorch \& Serpagli, 1993 (paraphyletic stem taxon)

Remarks. - We use this paraphyletic taxon in a somewhat expanded sense compared to Štorch \& Serpagli (1993) to encompass all the basal species of the Neograptina including those included in Normalograptus. Mitchell et al. (2007b) referred to this stem group as the Normalograptoidea, however we prefer to restrict paraphyletic taxa to family rank and below. We do not intend it to include all post-Hirnantian neograptines, particularly those species customarily referred to as monograptids and retiolitids (see Melchin 1998). Study of the phylogenetic relations among these higher Neograptina is beyond the scope of this study, however, and so we are unable to precisely define the full scope of this stem group at this time.

\section{Genus Normalograptus Legrand, 1987, emend. Melchin \& Mitchell, 1991}

Type species. - Climacograptus normalis Lapworth, 1877 , p. 138 , pl. 6 , fig. 31 ; by original designation.

\section{Normalograptus ajjeri (Legrand, 1977)}

Figures 25B-D, P, V, W, 26L, M, Table 21

1977 Climacograptus (Climacograptus) normalis ajjeri nov. subsp.; Legrand, p. 171, text-figs 9A-D, 10A, B.

1983 Climacograptus normalis Lapworth, 1877. - Koren' et al., p. 133, pl. 37, figs 1, 6-11; pl. 38, figs 1-5; text-fig. 48a-n.

Table 21. Normalograptus ajjeri. Dimensions of illustrated specimens (in mm).

\begin{tabular}{|c|c|c|c|c|c|c|c|c|c|}
\hline \multirow{2}{*}{\multicolumn{2}{|c|}{ Specimen USNM Text-figure }} & \multicolumn{4}{|c|}{ W } & \multicolumn{4}{|c|}{ 2TRD } \\
\hline & & th1 & th5 & th10 & dist. max & th2 & th5 & th10 & dist. th \\
\hline 542782 & $25 \mathrm{~B}$ & 0.95 & 1.2 & 1.25 & 1.3 & 1.7 & 1.85 & 1.85 & 1.9 \\
\hline 542831 & $25 \mathrm{C}$ & 0.7 & 1.15 & 1.25 & 1.35 & 1.5 & 1.65 & 1.65 & 1.75 \\
\hline 542694 & $25 \mathrm{D}$ & 0.9 & 1.2 & 1.4 & - & 1.85 & 2.0 & 2.1 & - \\
\hline 542815 & $25 \mathrm{P}, 26 \mathrm{M}$ & 0.85 & 1.2 & 1.45 & 1.45 & 1.8 & 2.0 & 2.05 & 2.1 \\
\hline 542717 & $25 \mathrm{~V}$ & 0.9 & 1.2 & 1.45 & - & 1.5 & 1.8 & - & - \\
\hline 542816 & $25 \mathrm{~W}, 26 \mathrm{~L}$ & $?$ & 1.25 & 1.45 & 1.45 & $?$ & 1.85 & 1.95 & 2.05 \\
\hline
\end{tabular}


1984 Climacograptus normalis Lapworth. - Chen, p. 40; pl. 2, figs 15,16 ; pl. 3, fig. 1; text-fig. 3 i.

1984 Climacograptus pseudonormalis; Li, p. 346, pl. 14, figs $10,13-17$.

1990 Climacograptus normalis Lapworth. - Fang et al., p. 69 , pl. 12, fig. 4; pl. 13, figs 11, 12.

1993 Normalograptus normalis (Lapworth). - Štorch \& Serpagli, p. 23, pl. 1, figs 3, 8; pl. 2, fig. 5; text-fig. $7 \mathrm{~L}, \mathrm{~N}$.

1995 Climacograptus pseudonormalis; Li, p. 241, pl. 3, fig. 20; pl. 8, figs 1-6, 8; pl. 26, fig. 11.

1999 Normalograptus normalis (Lapworth). - Li, p. 95, pl. 1, fig. 18.

2000 Normalograptus normalis (Lapworth, 1877). Koren' \& Melchin, p. 1101, fig. 7.14.

2001 Normalograptus (Normalograptus) normalis ajjeri (Legrand, 1977). - Legrand, p. 140, text-fig. 3a (?3b, non pl. 12, fig. 10).

2002 N. (Normalograptus) normalis ajjeri (Legrand). Legrand, pl. 12, figs 1-3; text-fig. 5a-c.

2003 Normalograptus normalis (Lapworth). - Loydell et al., fig. 3a.

2005a Normalograptus normalis (Lapworth, 1877). - Chen et al., p. 264, text-fig. 9J.

2007 Normalograptus ajjeri (Legrand, 1977). - Loydell, pp. 29, 30, text-figs 12G, 15A-F, H-I, O (and references therein).

Material and stratigraphical range. - 18 flattened specimens from lime mudstones of the extraordinarius and persculptus biozones at Vinini Creek section.

Description. - Medium-sized, 10-20 mm long, septate rhabdosome slightly tapering proximally, then parallelsided. Sicular aperture $0.2-0.3 \mathrm{~mm}$ wide, partly exposed on ventral side below th $1^{2}$. Virgella generally short (max length $2.2 \mathrm{~mm}$ ). Th $1^{1}$ grew downward $0.15-0.3 \mathrm{~mm}$ below sicular aperture before it turned upwards; ascending part $0.8-1.15 \mathrm{~mm}$ long. Rhabdosome width at th $1: 0.7-1.1 \mathrm{~mm}$, th3: $1.0-1.3 \mathrm{~mm}$, attaining maximum $1.25-1.6 \mathrm{~mm}$ at $7^{\text {th }}-12^{\text {th }}$ thecal pair. Median septum straight or, in some specimens, weakly undulose. Thecae climacograptid with sharp geniculum; supragenicular walls straight or slightly convex, approx. parallel to rhabdosome axis (may be slightly outwardly or inwardly inclined some $1-4^{\circ}$ ). Prominent apertural excavations occupy one-third to onequarter the rhabdosome width. $2 \mathrm{TRD}_{2}: 1.5-1.85 \mathrm{~mm}$, th5: $1.8-2.0 \mathrm{~mm}$, and $1.75-2.1 \mathrm{~mm}$ in distal parts of present, not fully mature specimens (see Table 21).

Remarks. - Present rhabdosomes match the traditionally accepted conception of $N$. normalis (Lapworth) in rhabdosome width, thecal form and spacing. However, Loydell (2007) re-examined the type material of $N$. normalis and found them to be some 1.8-2.0 mm wide without significant tectonic effects - significantly broader than the specimens generally assigned to $N$. normalis by previous authors, and suggested that these narrower specimens should be reassigned to the otherwise closely similar species Normalograptus ajjeri (Legrand). Thecae of present specimens vary slightly in profile depending on lithology. In laminated lime mudstones, which most clearly preserve the thecal form, a slightly developed hood may be observed at sharp and thickened geniculum.

\section{Normalograptus angustus (Perner, 1895)} Figures 25G, Q, 26H

1895 Diplograptus (Glyptograptus) euglyphus var. angustus mihi; Perner, p. 27, pl. 8, fig. 14a, b.

1906 Climacograptus scalaris var. miserabilis, Elles \& Wood, p. 186 (partim), pl. 26, fig. 3a, b, d, e (non c, f, h); text-fig. 120a, b, ?c.

1989 Scalarigraptus angustus (Perner, 1895). - Štorch, pp. 178-181, pl. 2, figs 3-5,8; text-fig. 2E-J.

2005a Normalograptus angustus (Perner, 1895). - Chen et al., pp. 252-255, text-figs 5D, I, K, Q, DD (see for further references on $N$. angustus and N. miserabilis).

2007 Normalograptus angustus (Perner, 1895). - Loydell, pp. 30, 32, 33, pl. 1, fig. 3, text-figs $15 \mathrm{~L}, \mathrm{M}$.

Material and stratigraphical range. - Eight flattened specimens from lime mudstones of the extraordinarius and persculptus biozones at Vinini Creek Section.

Remarks. - Present collection comprises immature, fully septate rhabdosomes attaining a maximum length of $12.8 \mathrm{~mm}$. Proximal end is $0.75-0.9 \mathrm{~mm}$ wide across the first thecal pair. The width of $1.0-1.15 \mathrm{~mm}$, measured at $5^{\text {th }}$ theca, does not represent maximum values attained by mature specimens. The $2 \mathrm{TRD}$ is $1.35-1.5 \mathrm{~mm}$ at th 2 and $1.6-2.0 \mathrm{~mm}$ at th5. The rather wide thecal spacing, slightly outwardly inclined supragenicular walls and strong genicula without genicular rims refer this form to $N$. angustus (Perner). Although this species typically possesses even more widely spaced thecae, the present specimens are relatively short and have probably not reached their maximum, distal thecal spacing. Immature rhabdosomes of $N$. ajjeri can be discriminated from $N$. angustus by their greater rhabdosomal width and stronger thecal geniculation. $N$. mirnyensis is readily distinguishable by its more dense thecal spacing, sharp thecal genicula, and sometimes concave or slightly inward-sloping supragenicular walls. In addition, $N$. angustus colonies often have a slightly undulating median septum. 
Table 22. Normalograptus elegantulus. Dimensions of illustrated specimens (in mm).

\begin{tabular}{|c|c|c|c|c|c|c|c|c|c|}
\hline \multirow{2}{*}{\multicolumn{2}{|c|}{ Specimen USNM Text-figure }} & \multicolumn{4}{|c|}{ W } & \multicolumn{4}{|c|}{ 2TRD } \\
\hline & & th1 & th5 & th10 & dist. max & th2 & th5 & th10 & dist. th \\
\hline $542690 \mathrm{a}$ & $26 \mathrm{~A}, 27 \mathrm{~J}$ & 1.05 & 1.5 & 1.85 & - & 1.7 & 2.05 & $?$ & 2.25 \\
\hline $542690 \mathrm{c}$ & $26 \mathrm{~J}, 27 \mathrm{~L}$ & 1.15 & 1.6 & - & - & 1.9 & 2.0 & - & - \\
\hline $542715 a$ & $27 \mathrm{M}$ & 1.2 & 1.6 & $?$ & 1.7 & 1.8 & 2.15 & 2.15 & - \\
\hline $542690 d$ & $25 \mathrm{~K}, 26 \mathrm{~A}$ & 1.0 & 1.55 & - & - & 1.95 & 2.3 & - & - \\
\hline $542689 \mathrm{a}$ & $25 \mathrm{R}, 26 \mathrm{~B}$ & 1.15 & 1.4 & - & - & 1.7 & 1.85 & - & - \\
\hline 542814 & $25 \mathrm{X}, 26 \mathrm{I}$ & 1.15 & 1.65 & - & $>1.65$ & 2.0 & 2.2 & - & - \\
\hline $542689 b$ & $25 \mathrm{Y}$ & 1.05 & 1.45 & - & $>1.55$ & 1.7 & 2.0 & - & - \\
\hline $542715 b$ & $25 Z$ & 1.1 & 1.45 & 1.5 & $?$ & 1.85 & 1.9 & 2.15 & 2.25 \\
\hline 542833 & 26D & 1.0 & 1.5 & 1.7 & 1.7 & 1.6 & 1.8 & 2.0 & 2.0 \\
\hline
\end{tabular}

Normalograptus elegantulus $(\mathrm{Mu} \& \mathrm{Ni}, 1983)$

Figures 25K, R, X-Z, 26A, B, D, I, J, 27J-M, Table 22

1983 Glyptograptus elegantulus sp. nov.; Mu \& Ni, pp. 161, 162, pl. 7, fig. 4; pl. 8, figs 1, 2, 10-13; text-fig. 3b, d.

1984 Glyptograptus temalaensis Jones. - Li, pp. 322, 323, pl. 2, figs 8, ?9-11.

1984 Diplograptus temalaensis (Jones). - Ni, p. 324, pl. 2, figs 4,5 ; ?text-fig. $1 \mathrm{~b}$.

Material and stratigraphical range. - More than 30 flattened rhabdosomes (16 measured in detail) preserved in lime mudstones of the persculptus Biozone in the highest part of the Vinini Creek section.

Description. - Rhabdosome septate, up to $18.7 \mathrm{~mm}$ long, widening rapidly to $c a$ th5 (th1: $0.9-1.15 \mathrm{~mm}$, th3: $1.2-1.5 \mathrm{~mm}$, th5: $1.4-1.65 \mathrm{~mm}$ ), then slowly attains width of $1.5-1.85 \mathrm{~mm}$ at th10. Maximum width of nearly $2.0 \mathrm{~mm}$ has been recorded in one mature specimen. Some rhabdosomes become uniserial distally. Sicula ca $2.0 \mathrm{~mm}$ long; aperture $0.2-0.35 \mathrm{~mm}$ wide. Proximal end markedly asymmetric; downward-grown part of th $1^{1} 0.2-0.4 \mathrm{~mm}$ below the sicular aperture; upward grown th $1^{1}$ is $0.9-1.1 \mathrm{~mm}$ long, that of th $1^{2} 0.9-1.2 \mathrm{~mm}$. Thecae glyptograptid with distinct, fairly sharp geniculum in the proximal thecae, becoming more flowing distally; supragenicular walls short, inclined at $5-20^{\circ}$ to the rhabdosome axis; apertural excavations tall and asymmetric, with horizontal apertures that occupy one-quarter to one-third the rhabdosome width. Distal thecae overlap one-third their length. $2 \mathrm{TRD}_{2}$ : 1.0-2.0 mm, 2TRD 5 : 1.9-2.3 mm, 2TRD dist attains 2.1-2.45 mm (8.5-9 in $10 \mathrm{~mm})$.

Remarks. - Present material matches well the specimens of $N$. temalaensis illustrated by Li (1984). The type specimens of $N$. temalaensis from Malaya, measured and figured by Jones (1973), show a more parallel-sided rhabdosome that reaches its maximum width by the $5^{\text {th }}-6^{\text {th }}$ thecal pair, with less inclined thecae throughout. They are also described as showing lateral torsion of the thecal apertures, but this may be an artefact of preservation. N. elegantulus bears typical glyptograptid thecae combined with normalograptid pattern $\mathrm{H}$ early astogeny (marked by th $1^{1}$ turning up well below the sicular aperture and as it grew around the primary th $1^{2}$ foramen present in the descending part of th $1^{1}$ ). Its proximal end is more asymmetrical in comparison with the otherwise similar N. lungmaensis (Sun, 1933). Mature rhabdosomes of $N$. lungmaensis exhibit gradual widening to a maximum of 2.1-2.4 $\mathrm{mm}$ and their distal thecae are more closely spaced than those of $N$. elegantulus.

Figure 25. A, H, M, N, S-U - Normalograptus extraordinarius (Sobolevskaya, 1974): A - USNM 542781a, N - USNM 542781b, level 27.25 m; H - USNM 542712, level 27.50 m. M - USNM 542821, level 27.85 m; S - USNM 542779, level 25.05 m; T - USNM 542738, level 24.50 m; U - USNM 542728, level 25.05 m. • O - Normalograptus sp.: USNM 542693, level 28.15 m. • E, F, I, J - Normalograptus mirnyensis (Obut \& Sobolevskaya, 1967): E - USNM 542805, level 28.60 m; F - USNM 542739, level 24.50 m; I - USNM 542691a, J - USNM 542691b, level 27.45 m. • G, Q - Normalograptus angustus (Perner, 1895): G - USNM 542842, level 27.70 m; Q - USNM 542813, level 27.70 m. • K, R, X-Z - Normalograptus elegantulus (Mu \& Ni, 1983): K - 542690d, level 27.45 m; R - USNM 542689a, Y - USNM 542689b, level 27.70 m; X - USNM 542814, level 27.85 m; Z - USNM 542715b, level 28.15 m. • L, AA - Normalograptus persculptus (Elles \& Wood, 1907): L - USNM 542780b, level 27.25 m; AA - USNM 542713, level 27.50 m. - B-D, P, V, W - Normalograptus ajjeri (Legrand, 1977): B - USNM 542782, level 27.25 m; C - USNM 542694a, D - USNM 542694b, scree; P - USNM 542815, level 26.00 m; V - USNM 542717, level 20.50 m; W - USNM 542816, level 27.70 m. • USNM 542717, 542728, 542738, 542739 and 542779 from the extraordinarius Biozone, USNM 542689a, b, 542690d, 542691a, b, 542693, 542712, 542713, 542715b, 542780b, 542781a, b, $542782,542813,542814,542815,542816,542821$ and 542842 from the persculptus Biozone of the Vinini Creek section. All figures $\times 6$. Scale bar equals $1 \mathrm{~mm}$. 
Petr Štorch et al. • Uppermost Ordovician graptolites of north-central Nevada

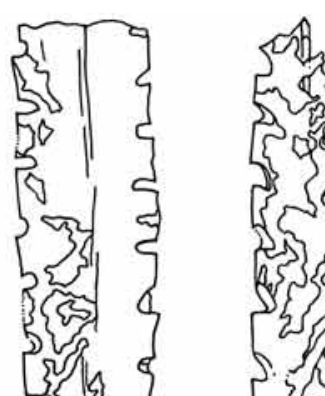

की ?

3

हुपा

[1

$501\}$

ए। $\}$

\{\}$_{A}$

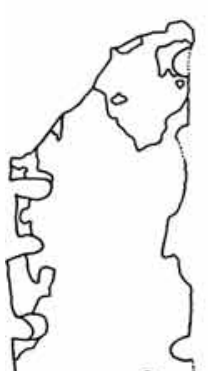

\& 5$]$

(2) $\Omega$

एक 25

$5\left\{\begin{array}{l}5 \\ \text { \{ }\end{array}\right.$

उर है

एक है

है?

एद है

है है

है

s.

by

5 5.

s

$\begin{cases}3 \\ 5\end{cases}$

519

किजो

$513: 5$

5

$\{\xi c$

3.

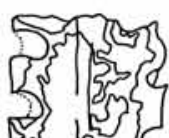

[स 15

56

की 1 है

5 sर

उतु

350

उदि है।

oु है है

है है

?

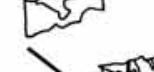

(2)

$\{505$

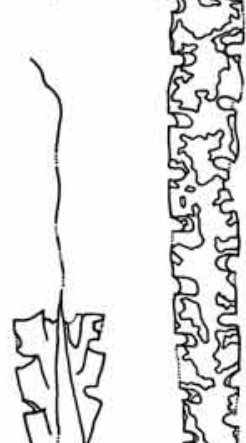

(1)

की

है के $\left\{\begin{array}{l}5 \\ \text { है }\end{array}\right.$

है।

5 है

$25^{\circ} \mathrm{u}$

Dद

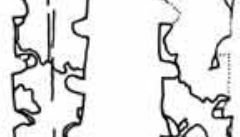

5
(1)

(3) 0 कीज

$\operatorname{los}_{\text {से }}$

क्या?

\{द 3$\}$

\{द 5 ,
$G$

?

रो

री:

ता?

तif $51 / 3$

तil? 51,5

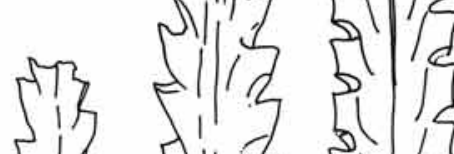

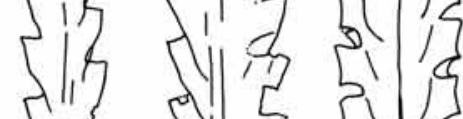

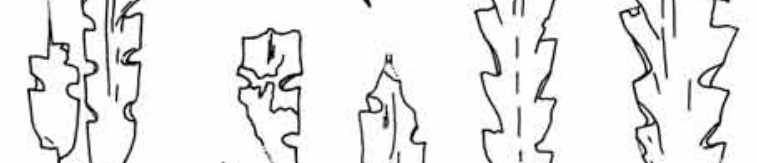

\{.

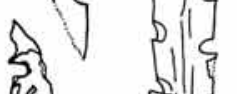

3

3ii

क्षा

西

S1\}

$\{3$

31,1

30

5ी?

这楼

है? है?

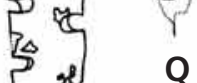

sus

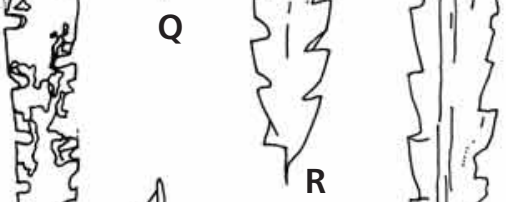

है

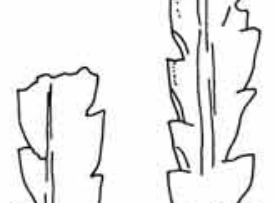

sing

$5\} \quad 512$

1)

sill'

$51 \%$

सा 11 ?

\{iv?

तil

(1): 12

रा11

तUity

Iin

$\sqrt[i n]{x}$ 
N. elegantulus also appears to be related to Normalograptus laciniosus (Churkin \& Carter, 1970), which can be differentiated by its shorter sicula $(1.2 \mathrm{~mm})$, which reaches only the first thecal aperture, and by the fact that the rhabdosome has a narrower proximal end from which it widens more rapidly and has more closely spaced thecae throughout. The type material $N$. laciniosus is narrower distally as well.

$N$. persculptus and $N$. ojsuensis are distinguishable from $N$. elegantulus by their more overlapping and more geniculate thecae and generally wider rhabdosome. Flattened specimens of $N$. elegantulus found on the same slabs with $N$. persculptus appears to have thinner walls. As in the type collections of $N$. elegantulus, rhabdosomes of this species collected from Vinini Creek section exhibit a tendency to develop a uniserial portion distally.

\section{Normalograptus extraordinarius (Sobolevskaya, 1974)}

Figures 25A, H, M, N, S-U, 27I, N-R, 28A, B, F, J, K, Table 23

1974 Fenhsiangograptus extraordinarius; Sobolevskaya, p. 69 , pl. 3, figs 6,7 .

1975 Diplograptus orientalis; Mu et al. (in Nanjing Institute of Geology and Palaeontology ed.), p. 213, pl. 98, fig. 11.

1978 Diplograptus orientalis Mu et al. - Wang \& Zhao (in Wang et al.), p. 641, pl. 207, fig. 6.

1979 Climacograptus? extraordinarius (Sobolevskaya). Koren' \& Sobolevskaya, pl. 23, figs 3-7.

1980 Glyptograptus persculptus (Salter) forma A. Koren' (in Apollonov et al.), p. 147, pl. 42, figs 4-6; pl. 43, fig. 1; pl. 44; figs 1-6; text-fig. 44a-k.

1982 Climacograptus? extraordinarius (Sobolevskaya). Williams, p. 40, text-fig. 9a-d.

1982 Diplograptus orientalis scariosus; Fu, p. 459, pl. 291, fig. 1 .

1983 Climacograptus? extraordinarius (Sobolevskaya, 1974). - Koren' \& Sobolevskaya (in Koren' et al.), pp. 108, 110; pl. 27, figs $6-11$; pl. 28, figs $1-4$; text-figs $35,36 \mathrm{a}-\mathrm{d}$.

1983 Glyptograptus? ojsuensis Koren' \& Mikhaylova, 1980. - Koren' \& Sobolevskaya (in Koren' et al.), pp. 142, 144 (partim); text-fig. 53k (non pl. 41, figs $7-12$; pl. 52, figs $1-3$; text-fig. 53a-i, 1).
1983 Climacograptus? extraordinarius (Sobolevskaya). Wang (in Wang et al.), p. 140, pl. 7, fig. 4; text-fig. 5a, b.

1989 Glyptograptus cf. ojsuensis Koren’ \& Sobolevskaya, 1980. - Štorch, pp. 181, 182 (partim), pl. 2, fig. 1 (non 2, 6, 7), text-fig. 2B (non A, C, D).

1993 Diplograptus orientalis $\mathrm{Mu}$ et al. - Mu (in Mu et al.), p. 132, pl. 21, figs $12-15$; pl. 22, figs 1-4; text-fig. $15 \mathrm{c}$ (see for further reference on $D$. orientalis).

1999 Normalograptus extraordinarius (Sobolevskaya, 1974). - Brussa et al., p. 220, fig. 2L?, O, P.

2002 Normalograptus extraordinarius (Sobolevskaya). Mu et al., pp. 697, 698, pl. 190, figs 19, 20.

2002 Normalograptus orientalis (Mu et al.). - Mu et al., p. 701, pl. 191, fig. 10.

2005a Normalograptus extraordinarius (Sobolevskaya, 1974). - Chen et al., pp. 256-259, pl. 1, figs 1,2; pl. 2, fig. 12; text-figs $6 \mathrm{C}, 7 \mathrm{H}, \mathrm{I}, 8 \mathrm{~W}$ (see for further reference on $N$. extraordinarius).

Material and stratigraphical range. - Common species of the extraordinarius and persculptus biozones at the Vinini Creek section (more than 60 specimens available, 35 measured). More-or-less flattened specimens came from lime mudstones and mudstones.

Description. - Rhabdosome large, >40 mm long, fully septate; widens fairly rapidly, th1: $0.9-1.2 \mathrm{~mm}$, th3: 1.2-1.6 mm, th5: $1.4-2.0 \mathrm{~mm}$, th10: $1.7-2.7 \mathrm{~mm}$. Maximum width, attained by th10-th18, varies from 2.1 to $3.0 \mathrm{~mm}$. Some specimens exhibit two phases of widening separated by almost parallel-sided interval in the mesial part of the rhabdosome (see Fig. 27I, O, R). Proximal end rounded, wide; furnished with tiny virgella. Sicular aperture $0.25-0.32 \mathrm{~mm}$ wide; sicular length $2.0-2.3 \mathrm{~mm}$ when complete. Descending portion of th $1^{1}$ extends $0.1-0.3 \mathrm{~mm}$ below sicular aperture; ascending portion $0.75-1.1 \mathrm{~mm}$ long. Ascending part of th $1^{2}$, which crosses the sicula slightly above its aperture, equally long. Climacograptid thecae overlap $c a$ half their length proximally, possibly as much as two-thirds distally. Thecae exhibit long infragenicular wall and strong geniculum; some specimens with prominent genicular thickening. Supragenicular wall $0.55-0.8 \mathrm{~mm}$ long, straight or slightly concave, parallel to

Figure 26. A, B, D, I, J - Normalograptus elegantulus (Mu \& Ni, 1983): A - USNM 542690a, J - 542690c, level 27.45 m; B - USNM 542689a, b, level 27.70 m; D - USNM 542833, level 27.85 m; I - USNM 542 814, level 27.85 m. • C, F, K - Normalograptus mirnyensis (Obut \& Sobolevskaya, 1967): C - USNM 542 739, level $24.50 \mathrm{~m}$; F - USNM 542692, level $28.15 \mathrm{~m}$; K - USNM 542691b, level $27.45 \mathrm{~m}$. E , G - Normalograptus sp.: E - USNM 542693, level 28.15 m; G - USNM 542723, scree. • H - Normalograptus angustus (Perner, 1895): USNM 542842, level $27.70 \mathrm{~m} . \bullet$ L, M - Normalograptus ajjeri (Legrand, 1977): L - USNM 542816, level $27.70 \mathrm{~m}$; M - USNM 542815, level $26.00 \mathrm{~m}$. • USNM 542723 and 542739 from the extraordinarius Biozone, USNM 542689a, b, 542690a, 542690c, 542691b, 542692, 542693, 542814, 542815, 542816, 542833 and 542842 from the persculptus Biozone of the Vinini Creek section. All figures $\times 6$. Scale bar equals $1 \mathrm{~mm}$. 
Petr Štorch et al. • Uppermost Ordovician graptolites of north-central Nevada
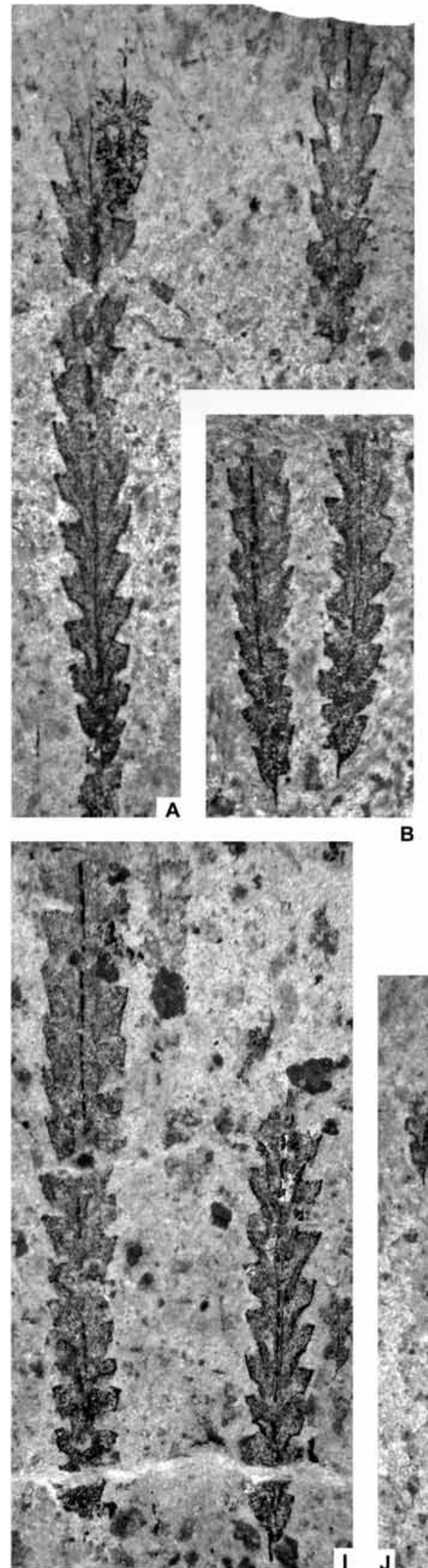
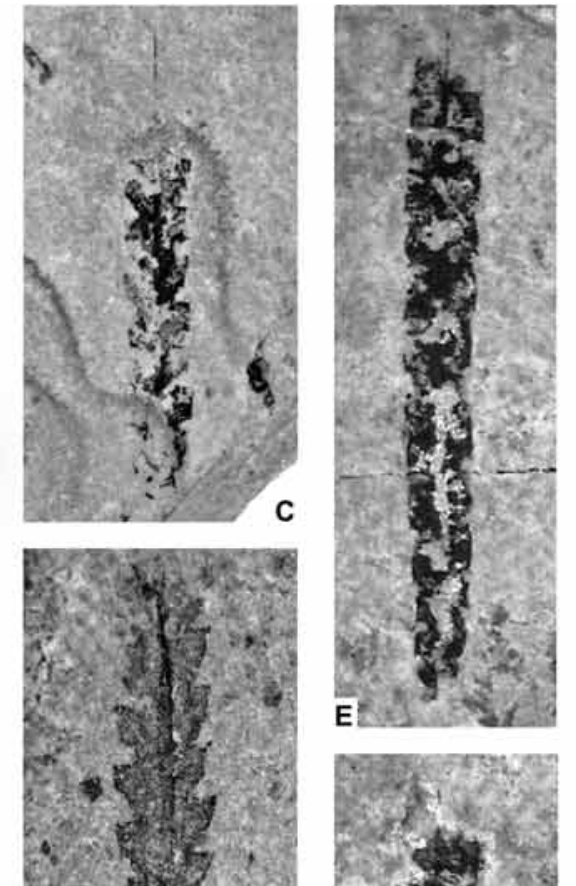

H.

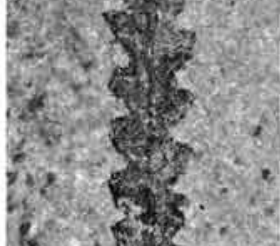

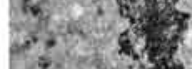
2. it

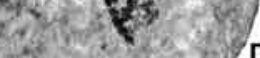

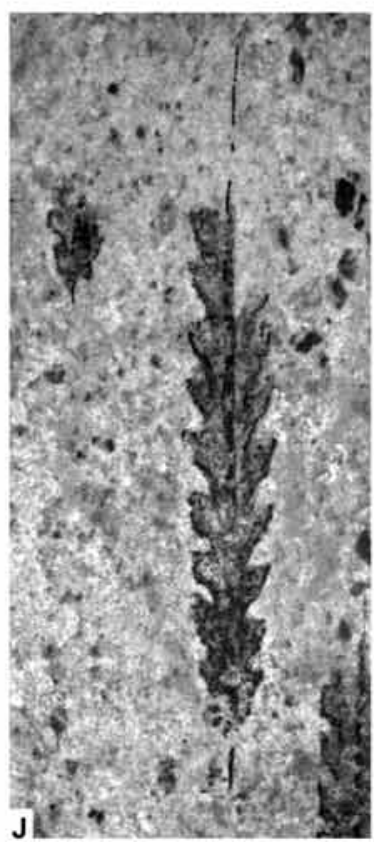

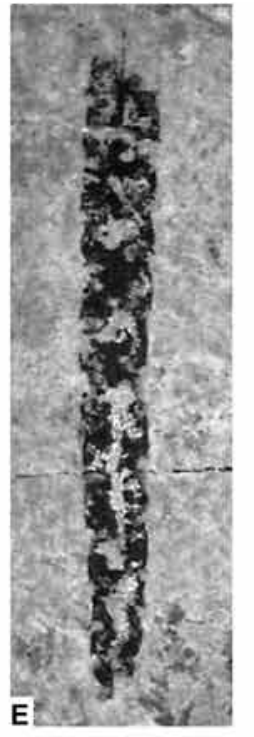
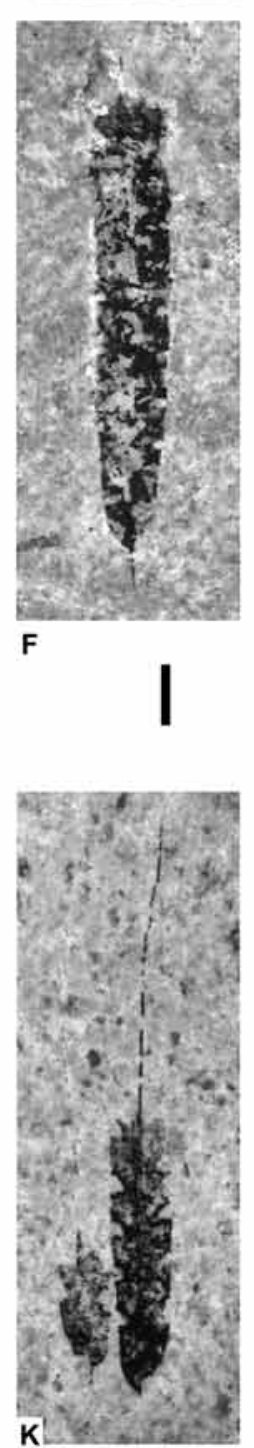
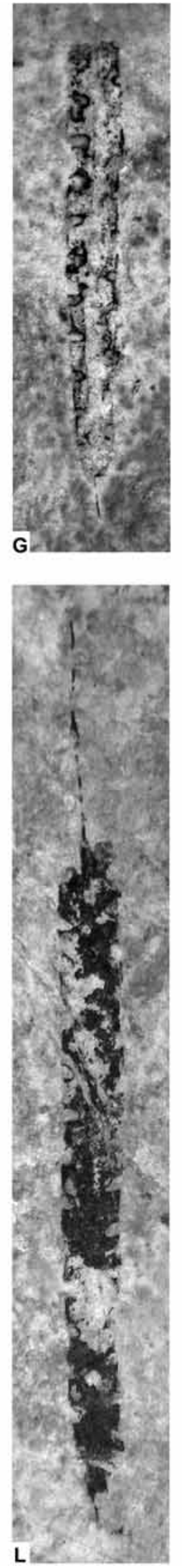
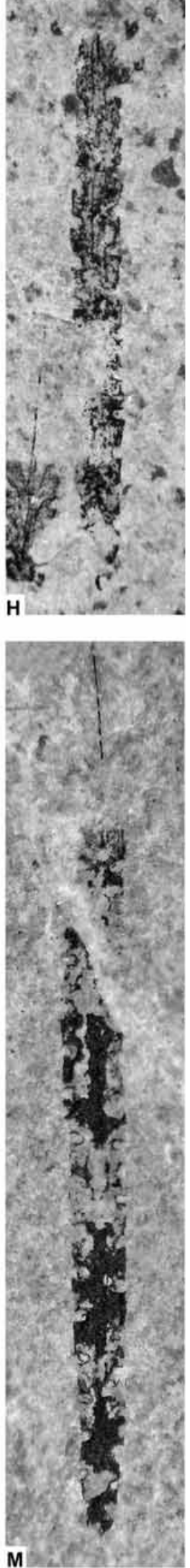
Table 23. Normalograptus extraordinarius. Dimensions of illustrated specimens (in mm).

\begin{tabular}{llllllllll}
\hline \multirow{2}{*}{ Specimen USNM Text-figure } & \multicolumn{3}{c}{ W } & \multicolumn{3}{c}{ 2TRD } \\
\cline { 3 - 9 } & & th1 & th5 & th10 & dist. max & th2 & th5 & th10 & dist. th \\
\hline $542830 \mathrm{a}$ & $27 \mathrm{I}, 28 \mathrm{~F}$ & 1.1 & 1.7 & 2.55 & - & 1.5 & 1.6 & - & - \\
542832 & $27 \mathrm{~N}$ & 0.9 & 1.8 & 2.3 & 2.8 & 1.7 & 1.85 & 1.75 & 1.85 \\
$542830 \mathrm{~b}$ & $27 \mathrm{O}$ & 1.2 & 1.7 & 2.0 & 2.8 & 1.5 & 1.7 & 1.85 & 2.0 \\
$542830 \mathrm{c}$ & $27 \mathrm{P}, 28 \mathrm{~J}$ & 0.95 & 1.7 & 2.05 & 2.8 & 1.5 & 1.75 & 1.9 & 2.05 \\
542721 & $27 \mathrm{Q}$ & 1.0 & 1.4 & 2.1 & 2.4 & 1.4 & 1.6 & 1.7 & - \\
542737 & $27 \mathrm{R}$ & 0.95 & 1.7 & 2.5 & 2.55 & 1.75 & $?$ & 2.3 & 2.0 \\
$364-1$ & $25 \mathrm{~A}$ & 1.0 & 1.65 & 2.2 & 2.4 & 1.5 & 1.65 & 1.95 & - \\
542712 & $25 \mathrm{H}$ & 0.95 & 1.45 & - & - & 1.5 & 1.55 & - \\
542821 & $25 \mathrm{M}, 28 \mathrm{~K}$ & 1.2 & 1.65 & 1.95 & 2.1 & 1.25 & 1.7 & 1.95 & 2.0 \\
542779 & $25 \mathrm{~S}$ & 0.9 & 1.75 & 2.4 & 2.85 & 1.75 & 2.15 & 2.2 & 2.4 \\
542738 & $25 \mathrm{~T}$ & 0.95 & 1.5 & 2.0 & 2.55 & 1.5 & 1.85 & 2.0 & 2.15 \\
542817 & $28 \mathrm{~B}$ & 1.2 & 1.9 & 2.15 & - & 1.55 & 1.7 & 1.8 & - \\
542821 & $28 \mathrm{~K}$ & 1.0 & 1.65 & 1.95 & 2.0 & 1.6 & 1.7 & 1.8 & 1.95 \\
\hline
\end{tabular}

rhabdosome axis or slightly outwardly inclined $\left(0-5^{\circ}\right)$. Thecal apertures face into relatively narrow, $0.25-0.32 \mathrm{~mm}$ wide, apertural excavations. 2TRD : 1.35-1.85 mm th5: 1.5-2.1 mm, th10: 1.6-2.2 mm. Distal thecae number $9-10$ in $10 \mathrm{~mm}\left(2 \mathrm{TRD}_{\text {dist }} 1.8-2.4 \mathrm{~mm}\right)$.

Remark. - Papers describing N. extraordinarius from different parts of the world illustrate significant morphological variability between and within populations. Also specimens from higher Hirnantian strata of the Vinini Creek section (levels 27.25-28.15, Figs 25H, M, 28B, K) differ from specimens collected from levels 24.50 and 25.05 (Figs 25S, T, U, 27I, N-R) near the base of the zone in this section. The former are typified by less widening, distally narrower rhabdosomes, whereas the latter are bottleshaped with less widening mesial part. Other parameters remain consistent throughout the stratigraphic range of the species.

\section{Normalograptus mirnyensis (Obut \& Sobolevskaya, 1967)}

Figures 25E, F, I, J, 26C, F, K, Table 24

1967 Hedrograptus mirnyensis n. sp.; Obut \& Sobolevskaya (in Obut et al.), p. 47, pl. 1, figs 4-9.

1980 Climacograptus mirnyensis (Obut \& Sobolevskaya, 1967). - Koren' \& Mikhaylova (in Apollonov et al.), p. 137, pl. 39, fig. 1; text-fig. 39.

1983 Climacograptus mirnyensis (Obut \& Sobolevskaya, 1967). - Koren' \& Sobolevskaya (in Koren' et al.), pp. 132, 133, pl. 37, figs 2-5; text-fig. 47K-H.

1984 Climacograptus mirnyensis (Obut \& Sobolevskaya). - Chen, p. 38, pl. 2, figs 12-14, text-fig. 3f-h.
1984 Climacograptus mirnyensis (Obut \& Sobolevskaya). - Li, p. 347, pl. 14, figs 8, 11.

1984 Climacograptus minutus Carruthers; Li, p. 348, pl. 15, fig. 12.

1990 Climacograptus mirnyensis (Obut \& Sobolevskaya). - Fang et al., p. 67, pl. 12, figs 2, 3, 10.

1990 Climacograptus minimus Carruthers. - Fang et al., p. 68 , pl. 13, figs 8-10.

?2000 Normalograptus mirnyensis (Obut \& Sobolevskaya). - Koren’ \& Melchin, pp. 1099-1101.

2005a Normalograptus mirnyensis (Obut \& Sobolevskaya, 1967). - Chen et al., pp. 262-264, text-fig. 8B, F, G, I, $\mathrm{L}-\mathrm{N}$.

2007 Normalograptus mirnyensis (Obut \& Sobolevskaya, 1967). - Loydell, pp. 37, 38, text-fig. 18A-E.

Material and stratigraphical range. - 12 small, flattened rhabdosomes preserved in lime mudstones of the extraordinarius and persculptus biozones at Vinini Creek section.

Description. - Rhabdosomes septate, those at hand attained maximum length $8.4 \mathrm{~mm}$. Sicula $1.2-1.5 \mathrm{~mm}$ long, aperture $0.25 \mathrm{~mm}$ wide with $1.0-1.5 \mathrm{~mm}$-long virgella. Dorsal margin of sicula little exposed below th $1^{2}$. Th $1^{1}$ grew downward $0.12-0.2 \mathrm{~mm}$ below the sicular aperture, ascending length $0.65-0.85 \mathrm{~mm}$. Th $1^{2}$ grew upwards for its entire $0.7-1.0 \mathrm{~mm}$ length. Rhabdosome width at th1 0.7-1.1 mm, th5: $1.05-1.15 \mathrm{~mm}$, maximum distal width observed: $1.2 \mathrm{~mm}$. Thecae strongly geniculate, densely spaced, with $2 \mathrm{TRD}_{2}: 1.2-1.6 \mathrm{~mm}, 2 \mathrm{TRD}_{5}: 1.45-1.55 \mathrm{~mm}$. Supragenicular walls straight, parallel-sided, more than twice as long as narrowly semicircular apertural excavations. 
Table 24. Normalograptus mirnyensis. Dimensions of illustrated specimens (in $\mathrm{mm}$ ).

\begin{tabular}{lllllll}
\hline \multirow{2}{*}{$\begin{array}{l}\text { Specimen } \\
\text { USNM }\end{array}$} & \multirow{2}{*}{ Text-figure } & \multicolumn{3}{c}{ W } & \multicolumn{3}{c}{ 2TRD } \\
\cline { 3 - 7 } & & th1 & th3 & th5 & th2 & th5 \\
\hline 542805 & $25 \mathrm{E}$ & 1.1 & 1.15 & 1.15 & 1.6 & - \\
542739 & $25 \mathrm{~F}, 26 \mathrm{C}$ & 0.9 & 1.0 & 1.05 & 1.35 & 1.55 \\
$542691 \mathrm{~b}$ & $25 \mathrm{~J}, 26 \mathrm{~K}$ & 0.85 & 1.0 & 0.95 & 1.5 & - \\
542692 & $26 \mathrm{~F}$ & 0.9 & 1.05 & 1.2 & 1.2 & 1.45 \\
\hline
\end{tabular}

Remarks. - Present material comprises small immature specimens matching $N$. mirnyensis in their dense thecal spacing ( $c a 6.5$ thecae in $5 \mathrm{~mm}$ ), strong thecal geniculation without thickened rims (or flanges) and parallel-sided supragenicular walls. Nema and virgella are well developed from an early astogenetic stage. Our rhabdosomes differ slightly, however, from others referred to this species (particularly from Chinese specimens described by Chen et al. 2005a) in their wider, rather blunt proximal end. Topotypical N. mirnyensis studied by Obut \& Sobolevskaya (1967) and Koren' et al. (1983) possesses even more densely spaced thecae, $12-14$ in $10 \mathrm{~mm}$ and $6.5-7.5 \mathrm{~mm}$ in proximal $5 \mathrm{~mm}$. $N$. angustus differs from $N$. mirnyensis in having more widely spaced thecae. This is the case also for $N$. $a j$ jeri, which is further differentiated by markedly wider rhabdosome.

\section{Normalograptus ojsuensis (Koren' \& Mikhaylova, 1980)}

Figures 27A-D, 28G-I, Table 25

1980 Glyptograptus ojsuensis sp. nov.; Koren’ \& Mikhaylova (in Apollonov et al.), pp. 143, 145; pl. 41, figs 1-8, pl. 42, figs 1, 2; text-fig. 43.

1983 Glyptograptus? ojsuensis Koren' \& Mikhaylova, 1980). - Koren' \& Sobolevskaya (in Koren' et al.), pp. 142, 144; pl. 41, figs 7-12; pl. 52, figs $1-3$; text-fig. 53а-и, л (non $\mathrm{\kappa}=$ extraordinarius).

1983 Diplograptus bohemicus (Marek). - Wang et al., pl. 7, figs 1-3, 11.

1984 Diplograptus ojsuensis (Koren' \& Mikhaylova). Ni, p. 323, pl. 1, figs 13, 14, pl. 2, figs 17, 18.

1989 Glyptograptus cf. ojsuensis Koren' \& Mikhaylova, 1980. - Štorch, pp. 181, 182 (partim), pl. 2, figs 2, 6, 7; text-fig. 2A, C, D (non pl. 2, fig. 1; text-fig. 2B).

1993 Glyptograptus (?Glyptograptus) ojsuensis Koren' \& Mikhaylova. - Legrand, p. 437, pl. 1, figs a-e; text-fig. 2a-g.

1993 Diplograptus bohemicus (Marek). - Lin (in Mu et al.), p. 129, pl. 21, figs 1-5 (see for further reference on Chinese D. bohemicus).

1993 Diplograptus vicatus; Lin (in Mu et al.), p. 130, pl. 21, figs 8-11.
2002 Diplograptus ojsuensis (Koren' \& Mikhaylova). Mu et al., p. 512, pl. 148, figs 9, 10.

2002 Normalograptus bohemicus (Marek). - Mu et al., p. 695 , pl. 143, fig. 16; pl. 159, fig. 6 .

2005a Normalograptus ojsuensis (Koren' \& Mikhaylova, 1980). - Chen et al., pp. 264, 265, pl. 1, figs 4, 7; pl. 2 , fig. 8; text-figs 9D, K, N, Q; 10I.

Material and stratigraphical range. - Common species of the extraordinarius and lower persculptus biozones at Vinini Creek section (more than 50 specimens available, 21 measured). More or less flattened specimens came from lime mudstones and mudstones.

Description. - Maximum length $>73 \mathrm{~mm}$ but more commonly 20-40 mm. Median septum is complete. Colony width at th1: $0.9-1.15 \mathrm{~mm}$, th3: $1.1-1.4 \mathrm{~mm}$, th5: 1.15-1.7 $\mathrm{mm}$, th10: 1.5-2.2 mm; maximum width $1.7-2.3 \mathrm{~mm}$ attained at $12^{\text {th }}-14^{\text {th }}$ theca or more distally. Sicular apex obscured, aperture $0.22-0.35 \mathrm{~mm}$ wide, with small, prominent virgella. Th $1^{1}$ extends $0.2-0.25 \mathrm{~mm}$ below the sicular aperture then turns abruptly upwards; ascending part $0.8-0.95 \mathrm{~mm}$ long. Thecae strongly geniculate; supragenicular walls straight, inclined about $5^{\circ}$ in the proximal part of the rhabdosome. Distal thecae exhibit less strong geniculation and more inclined supragenicular walls. Infragenicular walls relatively short; thecae overlap $<$ half their length. Large, asymmetrical apertural excavations at least one-quarter the rhabdosome width; apertures perpendicular to colony axis but, depending on mode of flattening, may appear slightly introverted (or slightly everted in opposite thecal series). Ratio of apertural excavation height to supragenicular wall length varies between $1: 1$ and $1: 2 ; 2 \mathrm{TRD}_{2}$ : is $1.4-1.85 \mathrm{~mm}$, th $5: 1.6-2.0 \mathrm{~mm}$, $1.7-2.3 \mathrm{~mm}$ distally.

Remarks. - In the Vinini Section N. ojsuensis is particularly common in lime mudstones of the lower part of the extraordinarius Biozone. It may be readily distinguished from N. extraordinarius by its markedly narrower rhabdosome, more protracted proximal end and considerably less geniculate and less overlapping thecae with relatively broad apertural excavations and longer, slightly inclined supragenicular walls. Present material of $N$. ojsuensis matches well the original descriptions of the species by Koren' \& Mikhaylova (in Apollonov et al. 1980) and Koren' et al. (1983). In accordance with both their and our own observations the species differs from closely similar $N$. persculptus in having a narrower proximal end (0.9-1.15 $\mathrm{mm}$ as oppose to $1.1-1.4 \mathrm{~mm}$ in the Vinini material). The same maximum distal width of the rhabdosome $(1.65-2.3 \mathrm{~mm})$ is attained well above th10 in N. ojsuensis whereas by th6-th9 in N. persculptus. N. ojsuensis may be further differentiated from $N$. persculptus by its more strongly geniculate 
Table 25. Normalograptus ojsuensis. Dimensions of illustrated and exemplary specimens (in mm).

\begin{tabular}{|c|c|c|c|c|c|c|c|c|c|}
\hline \multirow{2}{*}{\multicolumn{2}{|c|}{ Specimen USNM Text-figure }} & \multirow{2}{*}{$\frac{\mathrm{W}}{\mathrm{th} 1}$} & \multicolumn{7}{|c|}{ 2TRD } \\
\hline & & & th5 & th10 & dist. max & th2 & th5 & th10 & dist. th \\
\hline 542841 & $27 \mathrm{~A}$ & 0.9 & 1.3 & 1.55 & $>1.6$ & 1.55 & 1.75 & 1.95 & - \\
\hline 542804 & $27 \mathrm{~B}, 28 \mathrm{H}$ & 0.95 & 1.6 & 1.9 & 2.3 & 1.4 & 1.6 & 1.75 & 1.85 \\
\hline 542839 & $27 \mathrm{C}$ & 1.15 & 1.6 & 2.15 & 2.3 & 1.55 & 1.9 & 1.9 & 2.15 \\
\hline 542840 & $27 \mathrm{D}, 28 \mathrm{I}$ & 0.9 & 1.55 & 1.7 & 1.9 & 1.6 & 1.75 & 2.0 & 2.1 \\
\hline 542828 & - & 1.05 & 1.3 & 1.6 & 1.65 & 1.6 & 1.75 & 1.9 & $?$ \\
\hline 542844 & $28 \mathrm{G}$ & 0.9 & $?$ & 1.55 & 1.95 & 1.75 & $?$ & 2.1 & 2.2 \\
\hline
\end{tabular}

proximal thecae, relatively taller apertural excavations combined with slightly shorter infragenicular walls and, thus, slightly lesser thecal overlap and higher ratio of excavation height to supragenicular wall length $(>1.0)$.

\section{Normalograptus persculptus (Elles \& Wood, 1907)} Figures 25L,AA, 27E-H, 28C-E, Table 26

1865 Diplograptus persculptus (Salter); Salter, p. 25 (see Strachan 1971).

1907 Diplograptus (Glyptograptus) persculptus Salter. Elles \& Wood, p. 257, pl. 31, fig. 7a-c; text-fig. 176a, b.

1929 Glyptograptus aff. persculptus Salter. - Davies, p. 11 (partim); text-figs $11,13,16-18$ (non 12, $14, ? 19)$.

1955 Glyptograptus bohemicus n. sp.; Marek, pp. 7, 8, pl. 1, figs 1-4.

1975 Glyptograptus persculptus (Salter). - Bjerreskov, p. 30, text-fig. 11a-c.

1980 Glyptograptus persculptus (Salter), forma B. - Koren' \& Mikhaylova (in Apollonov et al.), p. 150, pl. 45, figs 1-6; pl. 46, figs 1-6 (?7, 8); text-fig. 45a-ж.

1983 Glyptograptus persculptus (Salter). - Wang et al., p. 139 (partim), pl. 8, figs 3, 5; pl. 9, figs 10, 11 (non pl. 8, figs 4, 6; pl. 9, fig. 5).

1983 Glyptograptus? persculptus (Salter, 1865). - Koren' \& Sobolevskaya (in Koren' et al.), pp. 144-148, pl. 42, figs 4-10; pl. 43; text-fig. 54a-p.

1984 Glyptograptus? persculptus (Salter). - Vandenberg et al., p. 10, figs 8,9 .
1984 Glyptograptus persculptus (Salter). - Chen \& Lin, pp. 193-195, pl. 1, figs 1-6; pl. 2, figs 3-9; text-fig. 1a-e.

1990 Glyptograptus persculptus-sinuatus transient; Fang et al., p. 60, pl. 8, figs 2, 3, 6 .

1994 Normalograptus? persculptus (Elles \& Wood, 1907). - Zalasiewicz \& Tunnicliff, p. 704, fig. 5a-c.

1996 Normalograptus persculptus (Elles \& Wood, 1907). - Štorch \& Loydell, pp. 872-875, text-figs 3A-G, $4 \mathrm{~A}-\mathrm{F}, 5 \mathrm{~A}-\mathrm{F}$ (see for further reference on $N$. persculptus).

2002 Normalograptus persculptus (Salter). - Mu et al., pp. 701, 702, pl. 162, figs 15, 16.

2005a Normalograptus persculptus (Elles \& Wood, 1907). - Chen et al., pp. 266, 268, text-figs 5B, 9A, F, L (see for further reference on $N$. persculptus).

Material and stratigraphical range. - More than 50 flattened rhabdosomes (26 measured in detail) preserved in various lime mudstones of the persculptus Biozone at the Vinini Creek section.

Description. - Up to $24 \mathrm{~mm}$ long, septate; width th1: 1.1-1.4 mm, th3: $1.35-1.8 \mathrm{~mm}$, th5: $1.7-2.2 \mathrm{~mm}$, maximum 1.7-2.3 mm by th6-th9. Sicula about $2 \mathrm{~mm}$ long; aperture $0.25-0.35 \mathrm{~mm}$ wide, with spike like, ca $1.0 \mathrm{~mm}$ long virgella. Downward-grown part of th $1^{1}$ turns up $0.2-0.35 \mathrm{~mm}$ below sicular aperture; ascending part $0.9-1.2 \mathrm{~mm}$ long. Proximal end asymmetrical as th $1^{2}$ crossed the sicula above its aperture and grew upwards for its entire length $(0.9-1.2 \mathrm{~mm})$. Thecae strongly sigmoidally curved, with prominent geniculum, horizontal or slightly everted aperture, 0.4-0.6 mm high apertural excavation

Figure 27. A-D - Normalograptus ojsuensis (Koren' \& Mikhaylova, 1980): A - USNM 542841, level 20.50 m; B - USNM 542804, level 20.00 m; C - USNM 542839, level 20.00 m; D - USNM 542840, level 20.00 m. • E-H - Normalograptus persculptus (Elles \& Wood, 1907): E - USNM 542835, scree; F - USNM 542719, scree; G - USNM 542780a, level 27.25 m; H - USNM 542778, level 27.25 m. • I, N-R - Normalograptus extraordinarius (Sobolevskaya, 1974): I - USNM 542830a, O - USNM 542830b, P - USNM 542830c, level 24.50 m; N - USNM 542832, level 24.50 m; Q - USNM 542721, scree; R - USNM 542737, level 25.05 m. • J-M - Normalograptus elegantulus (Mu \& Ni, 1983): J - USNM 542690a, K - USNM 542690b, L - USNM 542690c, level 27.45 m; M - USNM 542715a, level 28.15 m. • USNM 542721, 542737, 542804, 542830a-c, 542832, 542839, 542840 and 542841 from the extraordinarius Biozone, USNM 542690a-c, 542715a, 542719, 542778, 542780a and 542835 from the persculptus Biozone of the Vinini Creek section. All figures $\times 6$. Scale bar equals $1 \mathrm{~mm}$. 


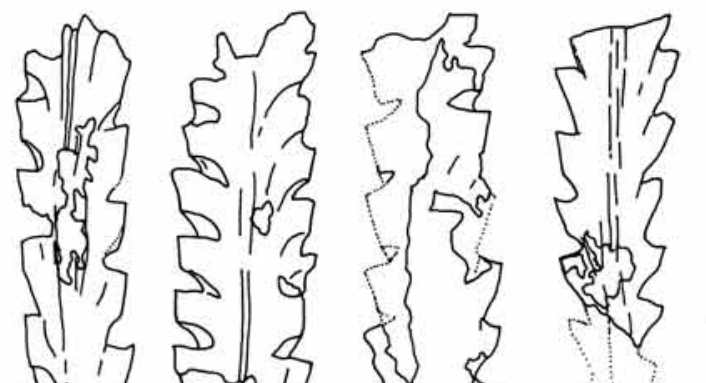

此触

激

政

游, $\{\|\}$

造, 50

एक

sits 5,5

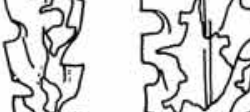

约

(1)

राi? 5ा? 5ी

$\left\{\sqrt{2}>r_{5}\right.$

(1)

512

$3 /$

3

5

एव.

s.

Si:

1.

5.

तु,

ज断

$\left\{\sum_{c}^{5}\right.$

1 A कित्द

s.

sis

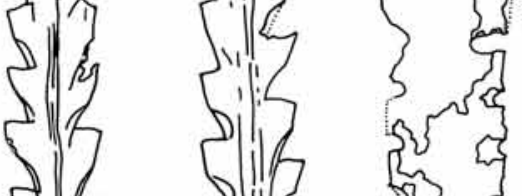

s

ग.

$\sqrt{K}$
Siln $\left\{\begin{array}{l}1 \\ 11 \\ 1\end{array}\right.$

$-11$

3

S! $11 / 3$

$311 \%$

S)|

की

\{ $5 \%$

D) $\{1\}$

3

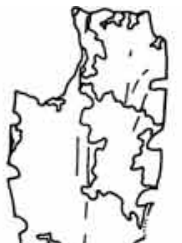

5,15

(3)

and

री 35$\}$

$\left\{\begin{array}{c}3 \\ 2\end{array}\right.$

DI\}



3

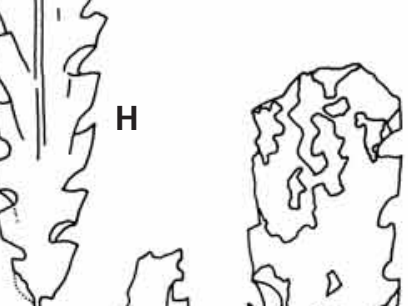

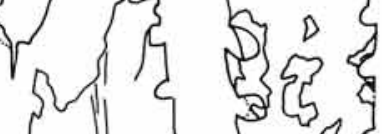

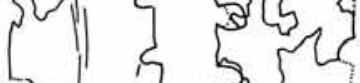

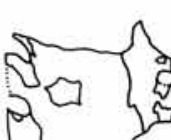

5 जिए 5,1

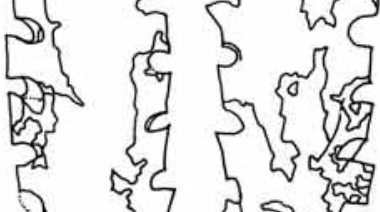

it 3$\}$ ?

D 3

तथ है।

D 59

कि

$\Leftrightarrow$ ?

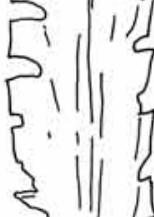

\{\}

एव

35

3

की

复 \{

ह 3

5 酉

एiv 0
हरे जी

० a

[3. 55

तs

सेत्र
$4 / 5$

$\left\{\begin{array}{l}3 \\ 3\end{array}\right.$

क्र

58

ति

\{\}

\{\}
पु जि

Dर\{?

$\{0\}$

-

की $ए$

3 है

(3) 
Table 26. Normalograptus persculptus. Dimensions of illustrated specimens (in mm).

\begin{tabular}{llllllllll}
\hline \multirow{2}{*}{ Specimen USNM Text-figure } & \multicolumn{4}{c}{ W } & \multicolumn{5}{c}{ 2TRD } \\
\cline { 3 - 9 } & 27E & th1 & th5 & th10 & dist. max & th2 & th5 & th10 & dist. th \\
\hline 542835 & $27 \mathrm{~F}$ & 1.4 & 2.2 & 2.2 & - & 1.35 & 2.05 & 2.0 & - \\
542719 & $27 \mathrm{G}$ & 1.2 & 2.0 & 2.25 & 2.05 & 1.7 & 2.0 & 2.15 & 2.15 \\
$542780 \mathrm{a}$ & $27 \mathrm{H}, 28 \mathrm{D}$ & 1.2 & 1.7 & 1.95 & 2.0 & 1.75 & 1.75 & 1.95 & 1.75 \\
542778 & $25 \mathrm{~L}, 28 \mathrm{E}$ & 1.3 & 1.9 & 2.0 & 2.0 & 1.85 & 2.05 & 2.25 & 2.25 \\
$542780 \mathrm{~b}$ & $25 \mathrm{AA}$ & 1.15 & 1.8 & 1.75 & - & 1.6 & 1.75 & 1.95 & - \\
542713 & $28 \mathrm{C}$ & 1.2 & 1.9 & $?$ & - & 2.0 & 2.1 & 2.5 & - \\
542818 & & 1.3 & 1.9 & 2.2 & 2.2 & 1.55 & 2.0 & 1.95 & $?$ \\
\hline
\end{tabular}

and $0.5-0.7 \mathrm{~mm}$ long, outward inclined, straight or slightly convex supragenicular wall. Thecae overlap for about half their length. $2 \mathrm{TRD}_{2}: 1.5-2.0 \mathrm{~mm}$, th5: $1.7-2.2 \mathrm{~mm}$, th10: $1.9-2.5 \mathrm{~mm}$ (distal thecae number $8-10$ in $10 \mathrm{~mm}$ ).

Remarks. - The present material agrees well with flattened specimens of Normalograptus persculptus from Wales (Elles \& Wood 1907), Bohemia (Štorch \& Loydell 1996), Kazakhstan (Koren' \& Mikhaylova in Apollonov et al. 1980) and NE Siberia (Koren' et al. 1983), among others. It can be differentiated from N. ojsuensis (Koren' \& Mikhaylova) by its wider proximal end and more overlapping, rather sigmoidal and less strongly geniculate thecae, although mode of geniculation varies upon preservation (mode of flattening and orientation of the rhabdosome to the bedding plane). The rhabdosome widens within the proximal 6-9 thecae whereas $N$. ojsuensis widens over at least the first 10-15 thecae. Flattened specimens seldom display the true insertion point of the median septum and thus cannot be related to the progressive delay of the median septum insertion in stratigraphically higher populations observed by Davies (1929) and Blackett et al. (2008). Both the lectotype and majority of topotypical specimens of $N$. persculptus from Wales (see Blackett et al. 2008 for further discussion) are partial- to full-relief pyrite internal moulds (steinkerns) showing internal details of the rhabdosome and insertion and undulation of the median septum. Blackett et al., in accordance with our own observations, noted that insertion and undulation of the median septum is largely obscured in flattened specimens. It can be barely seen when pressed through. Thecal geniculation itself must be treated with particular caution in taxonomic differentiation of normalograptid and neodiplograptid taxa, since its natural variation is much accentuated by mode of preservation. Normalograptus extraordinarius (Sobolevskaya) is readily distinguishable by its small, roughly semicircular apertural excavations, densely spaced thecae, generally parallel-sided ventral supragenicular walls and sharp geniculum with a thickened rim.

Normalograptus sp.

Figures 25O, 26E, G

Material and stratigraphical range. - Flattened rhabdosomes uncommon in limestones of the persculptus Biozone at Vinini Creek section (8 specimens available).

Remarks. - Some slender normalograptid rhabdosomes from the Vinini Creek section differ from $N$. ajjeri by their narrower rhabdosome widening from $0.8-0.9 \mathrm{~mm}$ to $1.0-1.2 \mathrm{~mm}$ and by weakly convex, slightly inward sloping supragenicular thecal walls. Their sharp genicula are furnished with a rim, and the narrow apertural excavation occupies at least one-quarter the rhabdosome width. Rhabdosomes assigned to $N$. angustus are distinguished by slightly more widely spaced thecae and rounded, rather than sharp, genicula. Specimens assigned to $N$. mirnyensis bear closely spaced thecae, again without genicular rims. Convex, slightly inward inclined supragenicular walls and wavy median septum of our specimens resemble Metaclimacograptus? pictus (Koren' \& Mikhaylova, 1980) which is, however, easily distinguished by its closely packed thecae, numbering $14.5-16$ in $10 \mathrm{~mm}$ as opposed to 11.5 in $10 \mathrm{~mm}$ in present rhabdosomes.

Figure 28. A, B, F, J, K - Normalograptus extraordinarius (Sobolevskaya, 1974): A - USNM 542781b, level 27.25 m; B - USNM 542817, level 27.70 m; F - USNM 542830a; J - USNM 542830c, level $24.50 \mathrm{~m}$; K - USNM 542821, level $27.85 \mathrm{~m}$. C C-E - Normalograptus persculptus (Elles \& Wood, 1907); C - USNM 542818, level 27.70 m; D - USNM 542778, level 27.25 m; E - USNM 542780b, level 27.25 m. • G-I - Normalograptus ojsuensis (Koren' \& Mikhaylova, 1980): G - USNM 542844, level 20.50 m; H - USNM 542804, level 20.00 m; I - USNM 542840 , level 20.00 m. - USNM 542804, 542830a, 542830c, 542840 and 542844 from the extraordinarius Biozone, USNM 542778, 542780b, 542781b, 542817, 542818 and 542821 from the persculptus Biozone of the Vinini Creek section. All figures $\times 6$, except $\mathrm{G} \times 3$ and $\mathrm{A} \times 10$. Common scale bar and assigned scale bars equal $1 \mathrm{~mm}$. 
Petr Štorch et al. • Uppermost Ordovician graptolites of north-central Nevada
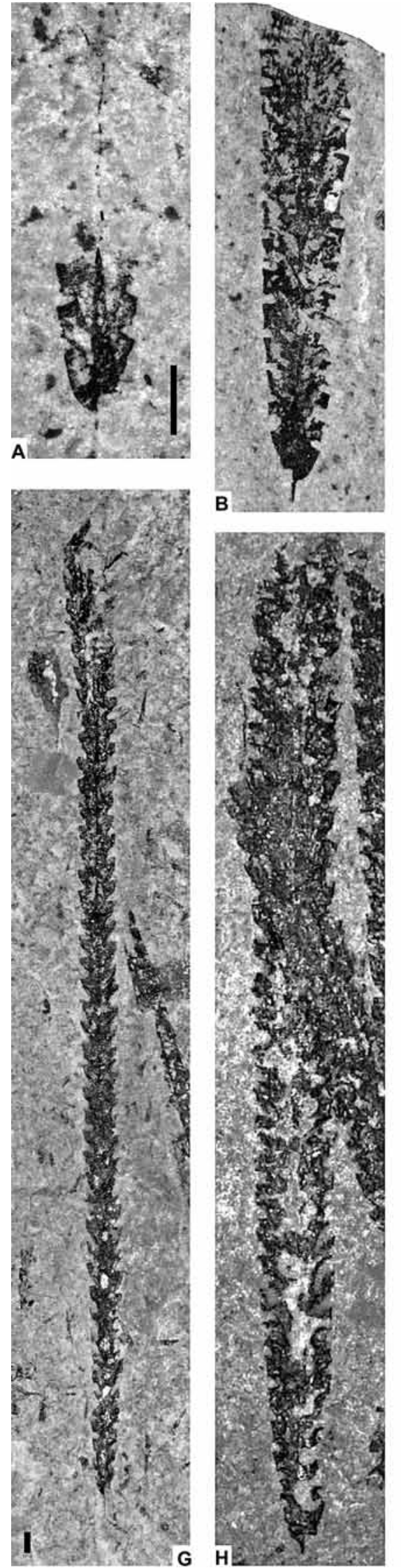

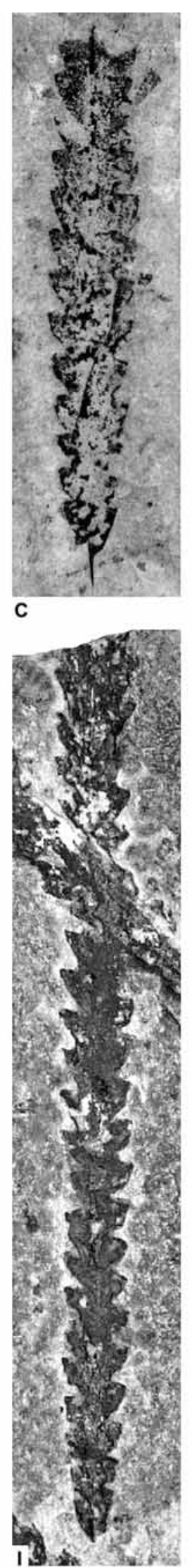

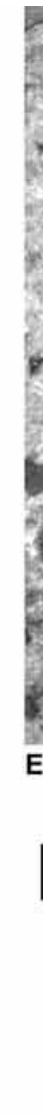
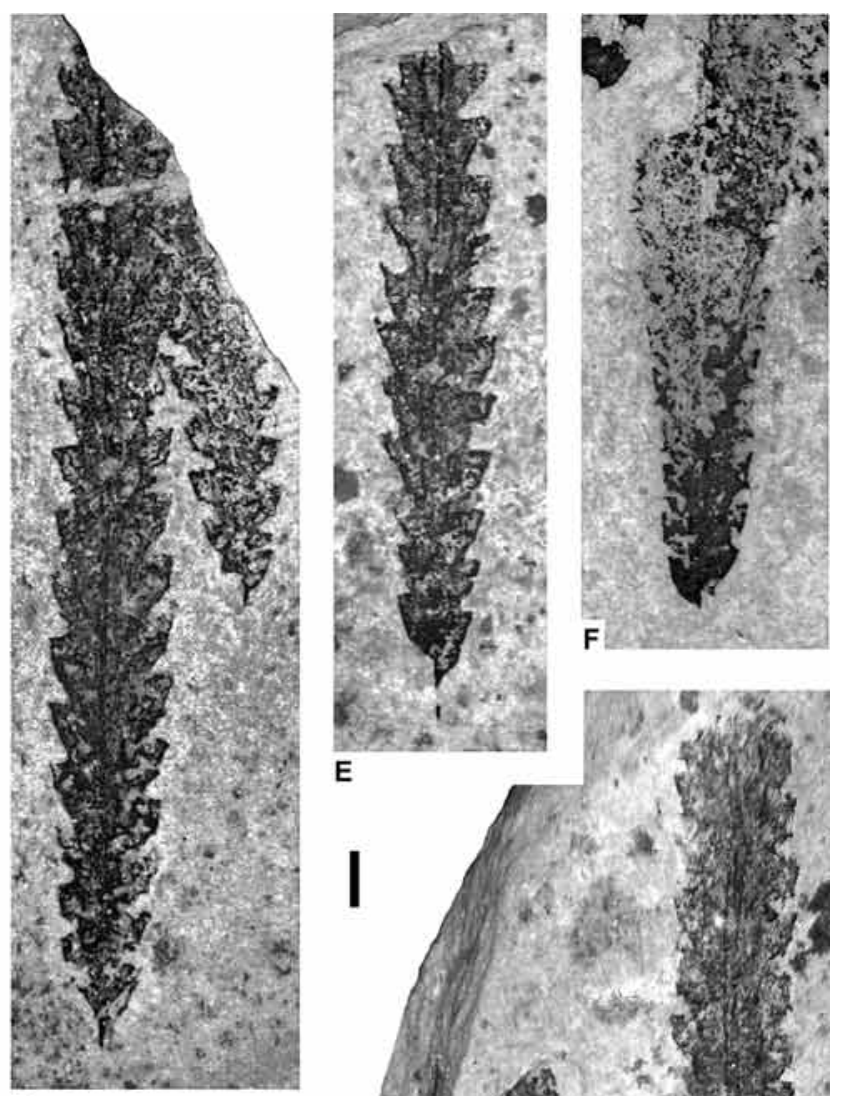

$$
\text { D }
$$

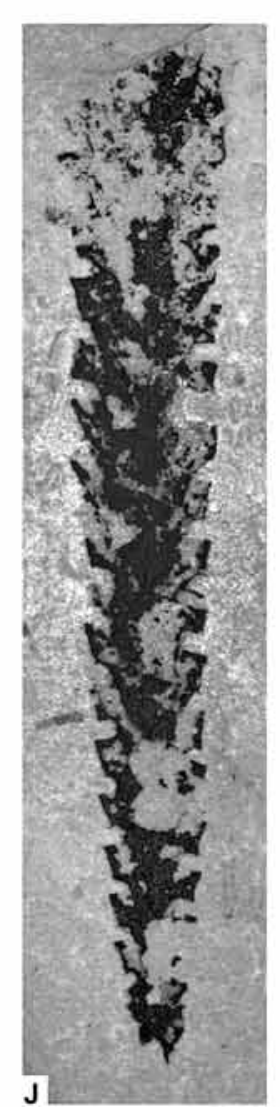




\section{Acknowledgements}

PŠ acknowledges Fulbright Visiting Scholar Program for research grant that permitted him to spend eight months in 2006-2007 at California State University Long Beach and conduct this study. His subsequent work was funded by Grant Agency of AS CR through grant IAA301110908. The present work was further supported by NSF grant EAR 0418790 to CEM, SCF, and MJM, and an NSERC (Canada) Discovery Grant to MJM. Jason Loxton, Dalhousie University, shared preliminary comparative data from his work on coeval faunas from the Blackstone River section, Yukon, and provided valuable insights into systematic issues surrounding many of the present taxa. Our thanks are due to Štěpán Manda for technical preparation of figures $1,3,4$, and 5 . This paper benefited from constructive reviews of Alfred C. Lenz and Chen Xu.

\section{References}

Alroy, J., Aberhan, M., BotTjer, D.J., Foote, M., Fürsich, F.T., Harries, P., Hendy, A.W., Holland, S.M., Ivany, L.C., Kiessling, W., Kosnik, M.A., Marshall, C.R., McGowan, A., Miller, A.I., Olszewski, T.D., Patzkowsky, M.E., Peters, S.E., Villier, L., Wagner, P.J., Bonuso, N., Borkow, P. S., Brenneis, B., Clapham, M.E., Fall, L.M., Ferguson, C.A., Hanson, V.L., Krug, A.Z., Layou, K.M., LeCKey, E.H., Nürnberg, S., Powers, C.M., Sessa, J.A., Simpson, C., Tomasovych, A. \& Visaggi, C.C. 2008. Phanerozoic Trends in the Global Diversity of Marine Invertebrates. Science 321, 97-100. DOI 10.1126/science.1156963

Apollonov, M.K., Bandaletov, S.M. \& Nikitin, J.F. 1980. The Ordovician-Silurian Boundary in Kazakhstan. 232 pp. Nauka, Kazakhstan SSR, Alma Ata. [in Russian]

Apollonov, M.K., Koren', T.N., Nikitin, I.F., PaletZ, L.M. \& TZAI, D.T. 1988. Nature of the Ordovician-Silurian boundary in south Kazakhstan, USSR, 145-154. In Cocks, L.R.M. \& RicKARDS, R.B. (eds) Bulletin of the British Museum (Natural History), Geology Series 43.

Bambach, R.K., KnOll, A.H. \& Wang, S.C. 2004. Origination, extinction, and mass depletions of marine diversity. Paleobiology 30, 522-542.

DOI 10.1666/0094-8373(2004)030<0522:OEAMDO>2.0.CO;2

BARRASS, R. 1954. Graptolites from Anticosti Island. Quarterly Journal of the Geological Society, London 110, 55-75. DOI 10.1144/GSL.JGS.1954.110.01-04.05

BATES, D.E.B. \& KIRK, N.H. 1991. The ultrastructure, mode of construction and functioning of Ordovician retiolitid graptolites from the Viola Springs Limestone, Oklahoma. Modern Geology 15, 131-286.

Bates, D.E.B., KozŁowska, A. \& Lenz, A.C. 2005. Silurian retiolitid graptolites: morphology and evolution. Acta Palaeontologica Polonica 50, 705-720.

Berry, W.B.N. 1966. Climacograptus hastatus T.S. Hall - its lectotype and some local populations. Journal of Paleontology 40, 162-176.

BerRy, W.B.N. \& FinNey, S.C. 1999. New insights into Late Ordovician graptolite extinctions, 191-193. In KRAFT, P. \&
FAtKA, O. (eds) Quo vadis Ordovician? Acta Universitatis Carolinae, Geologica 43(1/2).

Berry, W.B.N. \& Marshall, F.C. 1971. Late Ordovician graptolites from the Maquoketa Formation in Eastern Missouri. Journal of Paleontology 42, 253-257.

BerRy, W.B.N., Wilde, P. \& QuinBy-Hunt, M.S. 1990. Late Ordovician graptolite mass mortality and subsequent Early Silurian re-radiation, 115-123. In KAUfFMAN, E.G. \& WALLISER, O.H. (eds) Extinction Events in Earth History. Lecture Notes in Earth Sciences 8.

BJERRESKov, M. 1975. Llandoverian and Wenlockian graptolites from Bornholm. Fossils and Strata 8, 1-94.

Blackett, E., Page, A., Zalasiewicz, J., Williams, M., RicKARDS, B. \& DAVIS, J. 2008. A refined graptolite biostratigraphy for the Late Ordovician-early Silurian of central Wales. Lethaia 42, 83-96.

DOI 10.1111/j.1502-3931.2008.00108.x

Brenchley, P.J., Carden, G.A., Hints, L., Kaljo, D., Marshall, J.D., Martma, T., Meidla, T. \& NölvaK, J. 2003. High-resolution stable isotope stratigraphy of Upper Ordovician sequences: constraints on timing of bioevents and environmental changes associated with mass extinction and glaciation. Geological Society of America Bulletin 115, 89-104.

DOI 10.1130/0016-7606(2003)115<0089:HRSISO>2.0.CO;2

Brenchley, P.J., Marshall, J.D., Carden, G.A.F., Robertson, D.B.R., Long, D.G.F., Meidla, T., Hints, L. \& Anderson, T.F. 1994. Bathymetric and isotopic evidence for a short-lived Late Ordovician glaciation in a greenhouse period. Geology 22, 295-298.

DOI 10.1130/0091-7613(1994)022<0295:BAIEFA>2.3.CO;2

Brussa, E.D., Mitchell, C.E. \& Astini, R.A. 1999. Ashgillian (Hirnantian?) graptolites from the western boundary of the Argentine Precordillera, 199-202. In KRAFT, P. \& FATKA, O. (eds) Quo vadis Ordovician? Acta Universitatis Carolinae, Geologica 43(1/2).

Bulman, O.M.B. 1932. On the graptolites prepared by Holm Pts. 2-5. Arkiv för Zoologi 24A(9), 1-27.

Bulman, O.M.B. 1955. Graptolithina with sections on Enteropneusta and Pterobranchia. In Moore, R.C. (ed.) Treatise on Invertebrate Paleontology V. i-xvii, 101 pp. Geological Society of America, Boulder \& University of Kansas Press, Lawrence.

Bulman, O.M.B. 1970. Graptolithina with sections on Enteropneusta and Pterobranchia. In Teichert, C. (ed.) Treatise on Invertebrate Paleontology V. Second edition. xxxii, 163 pp. Geological Society of America, Boulder \& University of Kansas Press, Lawrence.

CARruthers, W. 1858. Dumfriesshire Graptolites, with a description of three new species. Proceedings of the Royal Physical Society of Edinburgh 1, 466-470.

CARruthers, W. 1867. Graptolites: their structure and systematic position. Intellectual Observer 11(4), 10(5), 64, 65.

CARTER, C. 1972. Ordovician (Upper Caradocian) graptolites from Idaho and Nevada. Journal of Paleontology 46, 43-49.

CARTer, C. \& Churkin, M. 1977. Ordovician and Silurian graptolite succession in the Trail Creek area, Central Idaho - a graptolite zone reference section. United States Geological Survey Professional Paper 1020, 1-37. 
CHEN Xu 1984. Silurian graptolites from southern Shaanxi and northern Sichuan with special reference to classification of Monograptidae. Palaeontologica Sinica, New Series B 20, 1-102. [in Chinese with English summary]

Chen Xu, Fan Jun-Xuan, Melchin, M.J. \& Mitchell, C.E. 2004. Patterns and processes of latest Ordovician graptolite extinction and survival in South China, 9-54, 1037-1038. In RoNG JIA-YU \& FANG, Z.J. (eds) Mass Extinction and Recovery - Evidences from the Palaeozoic and Triassic of South China. University of Science and Technology of China press, Hefei. [in Chinese with English abstract]

Chen Xu, Fan Jun-Xuan, Melchin, M.J. \& Mitchell, C.E. 2005a. Hirnantian (latest Ordovician) graptolites from the Upper Yangtze Region, China. Palaeontology 48, 235-280.

Chen Xu, Melchin, M.J., Sheets, H.D., Mitchell, C.E. \& Fan JUN-XUAN 2005b. Patterns and processes of latest Ordovician graptolite extinction and recovery based on data from South China. Journal of Paleontology 79, 842-861.

Chen Xu \& Lenz, A.C. 1984. Correlation of Ashgill graptolite faunas of Central China and Arctic Canada, with a description of Diceratograptus cf. mirus $\mathrm{Mu}$ from Canada, 247-258. In Nanjing Institute of Geology and Palaeontology, AcadeMIA SinICA (ed.) Stratigraphy and palaeontology of systemic boundaries in China, Ordovician-Silurian boundary (1). 516 pp. Anhui Science and Technology Publishing House, Hefei.

CHEN Xu \& Lin YAO-KUn 1984. On the material of Glyptograptus persculptus (Salter) from the Yangzi Gorges, China, 191-200. In Nanjing Institute of Geology and Palaeontology (ed.) Stratigraphy and Palaeontology of systemic boundaries in China, Ordovician-Silurian Boundary I. 516 pp. Anhui Science and Technology Publishing House, Anhui.

Chen Xu, Rong Jia-yu, Mitchell, C.E., Harper, D.A.T., Fan Jun-Xuan, Zhan Ren-bin, Zhang Yuan-dong, Li Rong-Yu \& WANG Yi 2000. Late Ordovician to earliest Silurian graptolite and brachiopod biozonation from the Yangtze region, South China, with a global correlation. Geological Magazine 137, 623-650.

Churkin, M. JR. \& CARTER, C. 1970. Early Silurian graptolites from southeastern Alaska and their correlation with graptolite sequences in North America and the Arctic. United States Geological Survey Professional Paper 653, 1-51.

Cox, I. 1933. On Climacograptus inuiti sp. nov. and its development. Geological Magazine 70, 1-19. DOI 10.1017/S0016756800091202

Cone, M.R. 2004. A cladistic and biostratigraphic analysis of Upper Ordovician climacograptid graptolites (Family Diplograptidae). 107 pp. Unpublished MS thesis, University at Buffalo, SUNY.

Davies, J.R., Fletcher, C.J.N., Waters, R.A., Wilson, D., Woodhall, D.G. \& Zalasiewicz, J.A. 1997. Geology of the county around Llanilar and Rhayader. Memoir of the British Geological Survey, Sheets 178 and 179 (England and Wales).

DAVIES, K.A. 1929. Notes on the graptolite faunas of the Upper Ordovician and Lower Silurian. Geological Magazine 66, 1-27. DOI 10.1017/S0016756800099763

Dunham, J.B. 1977. Depositional environments and paleogeography of the Upper Ordovician, Lower Silurian carbonate platform of central Nevada, 157-164. In STEWART, J.H.,
Stevens, C.H. \& Fritsche, A.E. (eds) Paleozoic Paleogeography of the Western United States I. 502 pp. Pacific Section SEPM, Book No 7.

DWORIAN, P.R. 1990. The biostratigraphy and biogeography of Upper Ordovician graptolites from North America. 168 pp. Unpublished MS thesis, California State University, Long Beach.

Elles, G.L. \& Wood, E.M.R. 1904. A monograph of British graptolites. Part 4. Monograph of the Palaeontographical Society 58(277), liii-lxii, 135-180.

Elles, G.L. \& Wood, E.M.R. 1906. A monograph of British graptolites. Part 5. Monograph of the Palaeontographical Society 60(288), lxxiii-xcvi, 181-216.

Elles, G.L. \& Wood, E.M.R. 1907. A monograph of British graptolites. Part 6. Monograph of the Palaeontographical Society 61(297), xcvii-cxx, 217-272.

Elles, G.L. \& Wood, E.M.R. 1908. A monograph of British graptolites. Part 7. Monograph of the Palaeontographical Society 62(305), cxxi-cxlviii, 273-358.

Fan Jun-Xuan, Peng Ping-an \& Melchin, M.J. 2009. Carbon isotopes and event stratigraphy near the Ordovician-Silurian boundary, Yichang, South China. Palaeogeography, Palaeoclimatology, Palaeoecology 276, 160-169. DOI 10.1016/j.palaeo.2009.03.007

FANG Yi-TING, LiANG SHI-JING, Zhang DA-LIANG \& YU JiN-LONG 1990. Stratigraphy and graptolite fauna of Lishuwo Formation from Wuning, Jiangxi. 155 pp. Nanjing University Publishing House, Nanjing. [in Chinese with English Summary]

FInNEY, S.C. 1985. Nemagraptid graptolites from the Middle Ordovician Athens Shale, Alabama. Journal of Paleontology 59, $1110-1137$.

FINNEY, S.C. 1986. Graptolite biofacies and correlation of eustatic, subsidence, and tectonic events in the Middle to Upper Ordovician of North America. Palaios 1, 435-461. DOI $10.2307 / 3514628$

FinNEY, S.C. \& BERRY, W.B.N. 1997. New perspectives on graptolite distributions and their use as indicators of platform margin dynamics. Geology 25, 919-922.

DOI 10.1130/0091-7613(1997)025<0919:NPOGDA>2.3.CO;2

FinNEY, S.C. \& BerRY, W.B.N. 1999. Late Ordovician graptolite extinction: the record from continental margin sections in central Nevada, USA, 195-198. In Kraft, P. \& FAtKA, O. (eds) Quo vadis Ordovician? Acta Universitatis Carolinae, Geologica $43(1 / 2)$.

Finney, S.C. \& BerRy, W.B.N. 2003. Ordovician to Devonian Graptolite Distributions Along the Cordilleran Margin of Laurentia, 27-32. In Ortega, G. \& AceñolazA, G.F. (eds) Proceedings of the $7^{\text {th }}$ International Graptolite Conference \& Field Meeting of the International Subcommission on Silurian Stratigraphy. Instituto Superior de correlacion Geologica INSUGEO, Serie Correlacion Geologica 18.

FInNEy, S.C., BERry, W.B.N. \& COOPER, J.D. 2007. The influence of denitrifying seawater on graptolite extinction and diversification during the Hirnantian (Latest Ordovician) mass extinction event. Lethaia 40, 281-291.

DOI 10.1111/j.1502-3931.2007.00027.x

FinNey, S.C., Berry, W.B.N., CoOper, J.D., RipPerdan, R.L., Sweet, W.C., Jacobsen, S.R., Soufiane, A., Achab, A. \& No- 
ble, P.J. 1999. Late Ordovician mass extinction: a new perspective from stratigraphic sections in central Nevada. Geology 27, 215-218.

DOI 10.1130/0091-7613(1999)027<0215:LOMEAN>2.3.CO;2

FinNey, S.C., BERRY, W.B.N. \& SwEET, W.C. 1995. An Important Ordovician/Silurian Boundary Interval section in Vinini Formation, Roberts Mountains, Nevada, 163-164. In CoOPER, J.D., Droser, M.L. \& FinNeY, S.C. (eds) Ordovician Odyssey: Short Papers for the Seventh International Symposium on the Ordovician System. Book No 77. 498 pp. Pacific Section SEPM, Society of Sedimentary Geologists, Fullerton.

Finney, S.C., CoOper, J.D. \& Berry, W.B.N. 1997. Late Ordovician mass extinction: sedimentologic, cyclostratigraphic, biostratigraphic and chemostratigraphic records from platform and basin successions, central Nevada, 79-103. In LiNK, P.K. \& Kowalis, B.J. (eds) Proterozoic to recent stratigraphy, tectonics and volcanology, Utah, Nevada, southern Idaho and central Mexico. BYU Geology Studies 42(1).

Finney, S.C., Noble, P.J. \& Cluer, J.K. 2000. Lower Paleozoic Stratigraphy and Structure of Central Nevada: Comparisons and Contrasts Between the Lower and Upper Plates of the Roberts Mountains Thrust. Geological Society of America Field Guide Series 2, 279-300.

FinNey, S.C. \& Perry, B.D. 1991. Depositional setting and paleogeography of Ordovician Vinini Formation, central Nevada, 747-766. In CoOPER, J.D. \& Stevens, C.H. (eds) Paleozoic Paleogeography of the Western United States, II. Book No 67. Pacific Section SEPM, Society of Sedimentary Geologists.

Finney, S.C., Perry, B.D., Emsbo, P. \& Madrid, R.J. 1993. Stratigraphy of the Roberts Mountains Allochthon, Roberts Mountains and Shoshone Range, Nevada, 197-230. In Lahren, M.M., Trexler, J.H., Jr. \& Spinosa, C. (eds) Crustal Evolution of the Great Basin and Sierra Nevada: Cordilleran/Rocky Mountain Section. Geological Society of America Guidebook, Department of Geological Sciences, University of Nevada, Reno.

Fortey, R.A. \& COOPER, R.A. 1986. A phylogenetic classification of the graptoloids. Palaeontology 29, 631-654.

FReCH, F. 1897. Lethaea Geognostica. Lethaea Paleozoica 1, 11, Graptolithen. Schweizerbart, Stuttgart.

Fu Han-yin 1982. Graptolithina, 410-479. In Geological BuREAU OF HUNAN (ed.) The palaeontological atlas of Hunan. Geological Memoirs of the Ministry of Geology and Mineral Resources, People's Republic of China 2(1). 997 pp. Geological Publishing House, Beijing. [in Chinese]

Fu Li-Pu, Zhang Zi-Fu \& Geng Lian-Gyu 2006. Silurian high-resolution graptolite biostratigraphy and biotic recovery in Ziyang, China. 151 pp. Geological Publishing House, Beijing.

Ge MeI-Yu 1984. Upper Ordovician graptolites from Kunshan, Jiangsu. Bulletin of Nanjing Institute of Geology and Palaeontology, Academia Sinica 12, 237-263.

Ge MeI-Yu, Zhen Zhao-Zhang \& Li Yu-Zhen 1990. Research of Ordovician and Silurian graptolites and graptolite-bearing strata from Ningxia and the neighbouring districts. 190 pp. Nanjing University Press, Nanjing. [in Chinese]

Goldman, D. \& BergströM, S.M. 1997. Biostratigraphy, biofacies, and taxonomy of Upper Ordovician graptolites from the North American Midcontinent. Palaeontology 40, 965-1010.

Goldman, D., Mitchell, C.E., Maletz, J., Riva, J.F.V., Leslie, S.A. \& Motz, G.J. 2007a. Ordovician Graptolites and Conodonts of the Phi Kappa Formation in the Trail Creek Region of Central Idaho: A revised, Integrated Biostratigraphy, 155-162. In Jun Li, Fan Jun-Xuan \& Percival, I. (eds) Proceedings of the $10^{\text {th }}$ International Symposium on the Ordovician System, Nanjing China. June 2007. Acta Palaeontologica Sinica 46 (Supplement).

Goldman, D., Leslie, S.A., Nõlvak, J., Young, S., Bergström, S.M. \& HuFF, W.D. 2007b. The Global Stratotype Section and Point (GSSP) for the base of the Katian Stage of the Upper Ordovician Series at Black Knob Ridge, Southeastern Oklahoma, USA. Episodes 30, 258-270.

Goldman, D. \& Wright, S.J. 2003. A revision of "Climacograptus" caudatus (Lapworth) based on isolated three-dimensional material from Viola Springs Formation of Central Oklahoma, USA, 33-37. In ORTEGA, G. \& AceÑolazA, G.F. (eds) Proceedings of the $7^{\text {th }}$ International Graptolite Conference \& Field Meeting of the International Subcommission on Silurian Stratigraphy. Instituto Superior de correlacion Geologica INSUGEO, Serie Correlacion Geologica 18.

GURLEY, R.R. 1896. North American graptolites; new species and vertical range. Journal of Geology 4, 63-102.

DOI $10.1086 / 607425$

HaLl, J. 1847. Descriptions of the organic remains of the lower division of the New York System. Paleontology of New York $1,265-274$.

HaLl, J. 1865. Figures and descriptions of Canadian organic remains. Decade II, Graptolites of the Quebec Group. 151 pp. Dawson Brothers, Geological Survey of Canada, Montreal.

HaLl, T.S. 1902. The Graptolites of New South Wales. Records of the Geological Survey of New South Wales 7, 49-59.

Hisinger, W. 1837. Lethaea Suecica seu Petrifacta Sueciae, Supplementum 1. 124 pp. Holmiae, Stockholm.

Hopkinson, J. 1871. On Dicellograptus, a new species of Graptolites. Geological Magazine 8, 20-26. DOI 10.1017/S001675680016087X

Hsü, S.C. 1959. A new graptolite fauna from the Lower Ordovician shale of Tsaidam, Chinghai Province. Acta Palaeontologica Sinica 7, 161-192. [in Chinese with English summary]

HutT, J.E. 1974. The Llandovery graptolites of the English Lake District. Part 1. Monograph of the Palaeontographical Society 128(540), 1-56.

InTERnational Commission on ZoOlogical Nomenclature (ed.) 1999. International Code of Zoological Nomenclature, $4^{\text {th }}$ Edition. 127 pp. International Trust of Zoological Nomenclature and Natural History Museum, London.

JACKSON, D.E. 1973. Amplexograptus and Glyptograptus isolated from Ordovician limestones in Manitoba. Geological Survey of Canada, Bulletin 222, 1-8.

JAEGER, H. 1977. Das Silur/Lochkov-Profil im Frankenberger Zwischengebirge (Sachsen). Freiberger Forschungshefte R. C 326, 45-59.

JaEger, H., HavlíčeK, V. \& Schönlaub, H.P. 1977. Biostratigraphie der Ordovizium/Silur Grenze in den Südalpen - 
Ein Beitrag zur Diskussion um die Hirnantia-Fauna. Verhandlungen der Geologischen Bundesanstalt 1975, 271-289.

Jones, C.R. 1973. The Siluro-Devonian graptolite fauna of the Malaya Peninsula. Institute of Geological Sciences, Overseas Geology and Mineral Resources 44(4), 1-28.

Jones, H., Zalasiewicz, J. \& Rickards, R.B. 2002. Clingfilm preservation of spiraliform graptolites: Evidence of organically sealed Silurian seafloors. Geology 30, 343-346. DOI 10.1130/0091-7613(2002)030<0343:CPOSGE >2.0.CO;2

Keble, R.A. \& Harris, W.J. 1925. Graptolites from Mt. Easton. Records of the Geological Survey of Victoria, Part 4(4), 79-481.

Keble, R.A. \& Harris, W.J. 1934. Graptolites of Victoria; new species and additional records. Memoirs of the National Museum, Melbourne 8, 166-183.

KelLER, B.M. 1956. Ordovician graptolites of the Chi-Illi Mountains, Kazakhstan. Trudy Geologicheskogo Instituta, Akademiya Nauk SSSR 1, 50-102. [in Russian]

Koren', T.N. 1979. Pacificograptus, a new late Ordovician diplograptid genus. Paleontological Journal 1979, 65-70.

Koren', T.N. 1991. Evolutionary crisis of the Ashgill graptolites, 157-164. In BARNES, C.R. \& Williams, S.H. (eds) Advances in Ordovician geology. Geological Survey of Canada, Paper 90-9. $335 \mathrm{pp}$.

Koren', T.N. \& Melchin, M.J. 2000. Lowermost Silurian graptolites from the Kurama Range, eastern Uzbekistan. Journal of Paleontology 74, 1093-1113. DOI 10.1666/0022-3360(2000)074<1093:LSGFTK>2.0.CO;2

Koren', T.N., Oradovskaya, M.M., Pylma, L.J., Sobolevskaya, R.F. \& Chugaeva, M.N. 1983. The Ordovician and Silurian Boundary in the Northeast of USSR. 205 pp. Nauka Publishers, Leningrad. [in Russian with English abstract]

Koren', T.N. \& Rickards, R.B. 1996. Taxonomy and evolution of Llandovery biserial graptoloids from the southern Urals, western Kazakhstan. Special Papers in Palaeontology 54, $1-103$.

Koren', T.N. \& SobolevSKayA, R.F. 1979. Atlas of palaeontological plates. Supplement to guidebook for the field excursion to the Omulev Mountains. 15 pp, 32 pls. Pacific Science Association, $14^{\text {th }}$ Pacific Science Congress. [in Russian]

Koren', T.N. \& SobolevsKayA, R.F. 2008. The regional stratotype section and point for the base of the Hirnantian Stage (the uppermost Ordovician) at Mirny Creek, Omulev Mountains, Northeast Russia. Estonian Journal of Earth Sciences 57(1), 1-10. DOI 10.3176/earth.2008.1.01

LaPorte, D.F., Holmden, C., Patterson, W.P., Loxton, J.D., Melchin, M.J. \& Mitchell, C.E. 2009. Local and global perspectives on carbon and nitrogen cycling during the Hirnantian glaciation. Palaeogeography, Palaeoclimatology, Palaeoecology 276, 182-195.

DOI 10.1016/j.palaeo.2009.03.009

LAPWORTH, C. 1873. Notes on the British graptolites and their allies. 1. On an improved classification of the Rhabdophora. Geological Magazine 1(10), 500-504, 555-560.

DOI 10.1017/S0016756800469256

Lapworth, C. 1877. On the graptolites of County Down. Proceedings of the Belfast Naturalists' Field Club, 1876-1877, $125-148$.
LAPWORTH, C. 1878. The Moffat Series. Quarterly Journal of the Geological Society of London 34, 240-346.

DOI 10.1144/GSL.JGS.1878.034.01-04.23

LAPWORTH, C. 1879. On the geological distribution of the Rhabdopleura. Annals and Magazine of Natural History, Series 5(3), 245-257, 449-455; (4), 333-341, 423-431.

LAPWORTH, C. 1880. The Silurian sequence of Rhayader. Quarterly Journal of the Geological Society of London 56, 67-137. DOI 10.1144/GSL.JGS.1900.056.01-04.09

Legrand, P. 1977. Contribution à l'étude des graptolites du Llandoverien inférieur de l'Oued In Djerane (Tassili N'ajjer oriental, Sahara algérien). Bulletin de la Société d'Histoire Naturelle de l'Afrique du Nord 67, 141-196.

Legrand, P. 1987. Modo de desarrollo del suborden Diplograptina (Graptolithina) en el Ordovício superior y en el Silúrico. Implicaciones taxonómicas. Revista Española de Paleontologia 2, 59-64.

LEGRAND, P. 1993. Graptolites d'àge ashgillien dans la region de Chirfa (Djado, République du Niger). Bulletin du Centres Recherches Exploration-Production Elf Aquitaine 17, 435-442.

Legrand, P. 2001. La faune graptolitique de la région d'In Azaoua (Tassili Oua-n-Ahaggar, confines algéro-nigériens). Annales de la Société Géologique du Nord 8, 137-158.

LENZ, A.C. 1977. Some Pacific faunal province graptolites from the Ordovician of northern Yukon, Canada. Canadian Journal of Earth Sciences 14, 1946-1952.

Lenz, A.C. \& McCracken, A.D. 1988. Ordovician-Silurian boundary, northern Yukon, Canada. In Cocks, L.R.M. \& RiCKARDS, R.B. (eds) Bulletin of the British Museum (Natural History), Geology Series 43, 265-271.

LI JI-JIN 1984. Graptolites from the Xinling Formation (Upper Ordovician) of South Anhui. Memoirs of Nanjing Institute of Geology and Palaeontology, Academia Sinica 20, 145-194.

LI JI-JIN 1995. Lower Silurian graptolites from the Yangtze Gorge district. Palaeontologica Cathayana 6, 215-344.

LI JI-JIN 1999. Lower Silurian graptolites from southern Anhui. Bulletin of the Nanjing Institute of Geology and Palaeontology, Academia Sinica 14, 70-157. [in Chinese with English summary]

Li Ji-JIN \& CHENG HAN-jun 1988. Graptolites from Nancheng Formation at Liangshan, Hanzhong of Shaanxi. Acta Palaeontologica Sinica 27(2), 164-178.

Li ZHI-MING \& Li DA-QING 1985. Appendispinograptus, a new subgenus of Climacograptus. Earth Science Journal of Wuhan College of Geology 10, 35-42. [in Chinese with English abstract]

LOYDELL, D.K. 2007. Graptolites from the Upper Ordovician and Lower Silurian of Jordan. Special Papers in Palaeontology 78, $1-66$.

Loydell, D.K., MänniK, P. \& Nestor, V. 2003. Integrated biostratigraphy of the lower Silurian of the Aizpute-41 core, Latvia. Geological Magazine 140, 205-229. DOI 10.1017/S0016756802007264

MaLeTZ, J. 1997. Graptolites from the Nicholsonograptus fasciculatus and Pterograptus elegans Zones (Abereiddian, Ordovician) of the Oslo Region, Norway. Greifswalder geowissenschaftliche Beiträge 4, 5-100. 
Maletz, J., Carlucci, J. \& Mitchell, C.E. 2009. Graptoloid cladistics, taxonomy and phylogeny. Bulletin of Geosciences 84,7-19. DOI 10.3140/bull.geosci.1108

MAREK, L. 1955. Glyptograptus bohemicus n. sp. z vrstev kosovských (dל2). Sborník Ústředního ústavu geologického, Oddíl paleontologický 24, 382-384.

McCoy, F. 1850. On Some New Genera and Species of Silurian Radiata in the collection of the University of Cambridge. Annals and Magazine of Natural History 6, 270-290.

Melchin, M.J. 1987. Upper Ordovician graptolites from the Cape Phillips Formation, Canadian Arctic Islands. Bulletin of the Geological Society of Denmark 35, 191-202.

MeLChin, M.J. 1998. Morphology and phylogeny of some early Silurian 'diplograptid' genera from Cornwallis Island, Arctic Canada. Palaeontology 41, 263-315.

Melchin, M.J. \& Anderson, A.J. 1998. Infrared video microscopy for the study of graptolites and other organic-walled fossils. Journal of Paleontology 72, 397-400.

Melchin, M.J. \& Holmden, C. 2006. Carbon isotope chemostratigraphy in Arctic Canada: Sea-level forcing of carbonate platform weathering and implications for Hirnantian global correlation. Palaeogeography, Palaeoclimatology, Palaeoecology 234, 186-200. DOI 10.1016/j.palaeo.2005.10.009

Melchin, M.J., McCracken, A.D. \& OlifF, F.J. 1991. The Ordovician-Silurian Boundary on Cornwallis and Truro islands, Arctic Canada: preliminary data. Canadian Journal of Earth Sciences 28, 1854-1862. DOI 10.1139/e91-165

Melchin, M.J. \& Mitchell, C.E. 1991. Late Ordovician extinction in the Graptoloidea, 143-156. In BARNES, C.R. \& WILLIAMs, S.H. (eds) Advances in Ordovician geology. Geological Survey of Canada, Paper 90-9, 335 pp.

Melchin, M.J., NaczK-Cameron, A. \& Koren', T.N. 2003. New Insights into the phylogeny of Rhuddanian (Lower Silurian) graptolites, 27-32. In Ortega, G. \& Aceñolaza, G.F. (eds) Proceedings of the $7^{\text {th }}$ International Graptolite Conference \& Field Meeting of the International Subcommission on Silurian Stratigraphy. Instituto Superior de correlacion Geologica INSUGEO, Serie Correlacion Geologica 18.

Melchin, M.J., Naczk-Cameron, A. \& Koren', T.N. 2005. Phylogenetic Analysis of some Rhuddanian (Lower Llandovery, Silurian) Graptolites. North American Paleontology Convention, Halifax, Nova Scotia, June 19-25, 2005, Program and Abstracts, 84-85.

Merriam, C.W. 1963. Paleozoic rocks of Antelope Valley, Eureka and Nye Counties, Nevada. United States Geological Survey Professional Paper 423, 1-67.

Merriam, C.W. \& Anderson, C.A. 1942. Reconnaissance survey of the Roberts Mountains, Nevada. Geological Society of America Bulletin 53, 1675-1728.

Mikнaylova, N.F. 1973. Graptolity verchnego ordovika i nizhnego silura Kazakhstana, 14-19. In Novoe v paleontologii Sibiri i Srednej Azii. 143 pp. Nauka, Novosibirsk.

Mitchell, C.E. 1987. Evolution and phylogenetic classification of the Diplograptacea. Palaeontology 30, 353-405.

Mitchell, C.E. 1988. The Morphology and Ultrastructure of Brevigraptus quadrithecatus n. gen, n. sp. (Diplograptacea), and its Convergence upon Dicaulograptus hystrix (Bulman). Journal of Paleontology 62, 448-463.
Mitchell, C.E., Belscher, K., Melchin, M.J., Loxton, J., Sheets, H.D., Štorch, P., Finney, S.C., Holmden, C., LAPORTE, D. \& PATterson, W.P. 2008. Ecological Reorganization of Graptolite Communities during the Hirnantian Mass Extinction. GSA Abstracts with Programs 40(6), 435.

Mitchell, C.E., Chen Xu \& Finney, S.C. 2007c. The structure and possible function of "basal membranes" in the spinose climacograptid graptolite Appendispinograptus $\mathrm{Li}$ and $\mathrm{Li}$, 1985. Journal of Paleontology 81, 1122-1127.

Mitchell, C.E., Goldman, D., Klosterman, S.L., Maletz, J., SheEts, H.D. \& Melchin, M.J. 2007b. Phylogeny of the Ordovician Diplograptoidea, 332-339. In JUN LI, FAN JUN-XUAN \& Percival, I. (eds) Proceedings of the $10^{\text {th }}$ International Symposium on the Ordovician System, Nanjing China, June 2007. Acta Palaeontologica Sinica 46 (Supplement).

Mitchell, C.E., Maletz, J. \& Goldman, D. 2009. What is Diplograptus? Bulletin of Geosciences 84(1), 27-34. DOI 10.3140/bull.geosci.1109

Mitchell, C.E., Sheets, H.D., Belscher, K., Finney, S.C., Holmden, C., LaPorte, D.F., Melchin, M.J. \& Patterson, W.P. 2007a. Species abundance changes during mass extinction and the inverse Signor-Lipps effect: Apparently abrupt graptolite mass extinction as an artifact of sampling, 340-346. In Jun Li, Fan Jun-Xuan \& Percival, I. (eds) Proceedings of the $10^{\text {th }}$ International Symposium on the Ordovician System, Nanjing China. June 2007. Acta Palaeontologica Sinica 46 (Supplement).

Mu EN-ZHI 1945. Graptolite faunas from the Wufeng Shale. Bulletin of the Geological Society of China 25, 201-209.

Mu En-ZHI 1949. Two Growth patterns of Climacograptus. Geological Reviews 14(4-6), 185-188. [in Chinese]

Mu EN-ZHI 1950. On the occurrence of Pleurograptus in China. Novitates of the Palaeontological Society of China 7, 1-4.

Mu EN-ZHi 1963a. On the complication of graptolite rhabdosome. Acta Palaeontologica Sinica 11, 346-377.

Mu EN-ZHI 1963b. Research in graptolite faunas of Chilianshan. Scientia Sinica 12(3), 347-371.

Mu En-Zhi, Li Ji-Jin, Ge Mei-Yu, Chen Xu, Lin Yao-Kun \& Ni YU-NAN 1993. Upper Ordovician graptolites of Central China Region. Palaeontologia Sinica, New Series B, 189(29), 1-393. [in Chinese with English summary]

Mu En-Zhi, Li Ji-Jin, Ge Mei-Yu, Lin Yao-kun \& Ni Yu-Nan 2002. Graptolites of China. 1205 pp. Science Press, Beijing. [in Chinese]

Mu EN-ZHI \& LiN YAO-KUn 1984. Graptolites from the Ordovician-Silurian boundary sections of Yichang area, S. Hubei, 45-73. In Nanjing Institute of Geology and Palaeontology, Academia Sinica (ed.) Stratigraphy and palaeontology of systemic boundaries in China, Ordovician-Silurian boundary 1. 516 pp. Anhui Science and Technology Publishing House, Hefei.

Mu EN-ZHI \& Ni Yu-NAN 1983. Uppermost Ordovician and lowermost Silurian graptolites from Xainza area of Xizang (Tibet) with a discussion on the Ordovician - Silurian boundary. Paleontologia Cathayana 1, 155-179.

Mu En-Zhi, Zhu Zhao-Ling, Lin Yao-Kun \& Wu Hong-Ji 1983. Ordovician-Silurian boundary of Yichang, Hubei, 94-106. In Papers for the Symposium on the Cambrian-Ordovician and 
Ordovician-Silurian boundaries Nanjing, China. 179 pp. Nanjing Institute of Geology and Palaeontology, Academia Sinica.

Nanjing Institute of Geology and Palaeontology (ed.) 1974. A handbook of stratigraphy and palaeontology of south-west China. 454 pp. Science Press, Beijing. [in Chinese]

Ni YU-NAn 1984. Upper Ordovician graptolites from Baoshan, western Yunnan. Acta Palaeontologica Sinica 22, 320-327. [in Chinese with English summary]

Nicholson, H.A. 1867. On some fossils from the Lower Silurian rocks of the South of Scotland. Geological Magazine 1(4), 107-113. DOI 10.1017/S0016756800205293

OBut, A.M. \& SoBolevsKayA, R.F. 1974. Graptolites, 85-159. In Palaeozoic reference sections of the North-East USSR. Nauka, Magadan.

Obut, A.M., Sobolevskaya, R.F. \& Nikolaev, A.A. 1967. Graptolites and stratigraphy of the lower Silurian along the margins of the Kolyma massif. 164 pp. Akademiya Nauk SSR, Sibirskoje Otdelenie, Institut Geologii i Geofiziki, Ministerstvo Geologii SSSR, Nauchno-Issledovatel'sky Institut Geologii Arktiky. [in Russian]

Perner, J. 1895. Études sur les Graptolites de Bohême. III ième Partie. Monographie des Graptolites de l'Étage D. 31 pp. Raimond Gerhard, Prague.

PřiBYL, A. 1949. Révision of the Diplograptidae and Glossograptidae of the Ordovician of Bohemia. Bulletin Internationale de l'Académie Tchèque des Sciences 50, 1-51.

RickARDS, R.B. 2002. The graptolitic age of the type Ashgill Series (Ordovician), Cumbria, UK. Proceedings of the Yorkshire Geological Society 54(1), 1-16. DOI 10.1144/pygs.54.1.1

Rickards, R.B., SHERwin, L. \& Williamson, P. 2001. Gisbornian (Caradoc) graptolites from New South Wales, Australia: systematics, biostratigraphy and evolution. Geological Journal 36, 59-86. DOI 10.1002/gj.876

RiPPERDAN, R.L., COOPER, J.D. \& FinNEY, S.C. 1998. High resolution $\delta^{13} \mathrm{C}$ and lithostratigraphic profiles from Copenhagen Canyon, Nevada: Clues to the behavior of ocean carbon during the Late Ordovician global crisis. Mineralogical Magazine 62a, 1279-1280. DOI 10.1180/minmag.1998.62A.3.03

RivA, J. 1969. Middle and Upper Ordovician graptolite faunas of the St. Lawrence Lowlands and of Anticosti Island, 513-556. In Kay, M. (ed.) North Atlantic Geology and Continental Drift. American Association of Petroleum Geologists, Memoir 12.

RIVA, J. 1974. Late Ordovician spinose climacograptids from the Pacific and Atlantic faunal provinces, 107-126. In RicKARDS, R.B., JACKSON, D.E \& Hughes, C.P. (eds) Graptolite studies in honour of O. M. B. Bulman. Special Papers in Palaeontology $13,1-260$.

Riva, J. 1988. Graptolites at and below the Ordovician-Silurian boundary on Anticosti Island, Canada, 221-237. In Cocks, L.R.M. \& RickARDS, R.B. (eds) Bulletin of the British Museum (Natural History), Geology Series 43.

Riva, J. \& Ketner, K.B. 1989. Ordovician graptolites from the northern Sierra de Cobachi, Sonora, Mexico. Transactions of the Royal Society of Edinburgh: Earth Sciences 80, 71-90.

Ross, R.B. \& BERRY, W.B.N. 1963. Ordovician graptolites of the Basin Ranges in California, Nevada, Utah and Idaho. United States Geological Survey Bulletin 1134, 1-177.
Ruedemann, R. 1908. Graptolites of New York, Part 2. Graptolites of higher beds. Memoirs of the New York State Museum of Natural History, Albany 11, 457-583.

Ruedemann, R. 1925. The Utica and Lorraine formations of New York, Part 2. Systematic paleontology. New York State Museum Bulletin 262, 1-175.

Ruedemann, R. 1947. Graptolites of North America. Geological Society of America, Memoir 19, 1-652.

Salter, J.W. 1865. In Huxley, T.H. \& Etheridge, R.A. (eds) A catalogue of the collection of fossils in the Museum of Practical Geology. 381 pp. London.

Sheehan, P.M. 2001. The Late Ordovician mass extinction. Annual Reviews of Earth and Planetary Sciences 29, 331-364. DOI 10.1146/annurev.earth.29.1.331

Skevington, D. \& PARIS, F. 1975. Les graptolithes de la formation de Saint-Germain-sur-Ille (Ordovicien supérieur du Massif Armoricain). Bulletin de la Société Géologique de France 12, 260-266.

Sobolevskaya, R.F. 1969. New Late Ordovician graptolites of the Omulev Mountains. Palaeontologicheski Zhurnal 1, 115-118. [in Russian]

SobolevsKaya, R.F. 1974. New Ashgill graptolites in the middle flow basin of the Kolyma River, 63-71. In Oвut, A.M. (ed.) Graptolites of the USSR. 160 pp. Nauka, Siberian Branch, Novosibirsk. [in Russian]

Stewart, S. \& Mitchell, C.E. 1997. Anticostia, a distinctive new Late Ordovician "glyptograptid" (Diplograptacea, Graptoloidea) based on three-dimensionally preserved specimens from Anticosti Island, Quebec. Canadian Journal of Earth Sciences 34, 215-228. DOI 10.1139/e17-018

ŠTORCH, P. 1989. Late Ordovician graptolites from the upper part of the Králův Dvůr Formation of the Prague Basin (Barrandian, Bohemia). Věstník Českého geologického ústavu 64, 173-186.

Štorch, P. \& Leone, F. 2003. Occurrence of the late Ordovician (Hirnantian) graptolite Normalograptus ojsuensis (Koren' and Mikhaylova, 1980) in south-western Sardinia, Italy. Bolletino della Società Paleontologica Italiana 42, 31-38.

ŠTorch, P. \& Loydell, D.K. 1996. The Hirnantian graptolites Normalograptus persculptus and "Glyptograptus" bohemicus: stratigraphical consequences of their synonymy. Palaeontology 39, 869-881.

S̆Torch, P. \& Serpagli, E. 1993. Lower Silurian Graptolites from Southwestern Sardinia. Bollettino della Società Paleontologica Italiana 32, 3-57.

Strait, D.S., Moniz, M.A. \& Strait, P.T. 1996. Finite mixture coding: a new approach to coding continuous characters. Systematic Biology 45(1), 67-78.

DOI 10.1093/sysbio/45.1.67

Stratigraphy Research group of the Yangtze Gorges, Hubei Bureau of Geology (ed.) 1978. Sinian to Permian stratigraphy and paleontology of eastern Yangtze Gorges. 381 pp. Geological Publishing House, Beijing. [in Chinese]

Sun Yun-ZHu 1933. Ordovician and Silurian graptolites from China. Palaeontographica Sinica B14, 1-52.

Toghill, P. 1970. Highest Ordovician (Hartfell Shales) graptolite faunas from the Moffat area, south Scotland. Bulletin of the British Museum (Natural History), Geology 19(1), 1-26. 
VAndenberG, A.H.M. 1990. The ancestry of Climacograptus spiniferus Ruedemann. Alcheringa 14, 39-51. DOI 10.1080/03115519008619005

VANDENBERG, A.H.M. 2003. Discussion of "Gisbornian (Caradoc) graptolites from New South Wales, Australia: systematics, biostratigraphy and evolution" by B. Rickards, L. Sherwin and P. Williamson. Geological Journal 38, 175-179. DOI $10.1002 /$ gj.939

VANDENBERG, A.H.M., RickARDS, R.B. \& Holloway, D.J. 1984. The Ordovician-Silurian boundary at Darrawit Guim, central Victoria. Alcheringa 8, 1-22. DOI 10.1080/03115518408619607

WANG GANG \& Zhao YU-Ting 1978. Graptolithina, 595-660. In Palaeontological Atlas of Southwest China, Guizhou Volume, Part 1. Geological Publishing House, Beijing. [in Chinese]

WANG Jue-de et al. 1974. Graptolites, 731-761. In YunAn BuReau of Geology (ed.) Fossil Atlas of Yunan, Part 1. Peoples Publishing House of Yunan, Kunming. China. [in Chinese]

Wang XiaO-Feng, Jin Yu-Qin \& Wu Zhao-tong 1978. Graptolites of central South China, 266-371. In HuBEI InstituTE OF Geological Sciences (ed.) Handbook of Palaeontological Atlas of central South China, Part 1: Early Palaeozoic. 470 pp. Geological Publishing House, Beijing. [in Chinese]

Wang XiaO-Feng, Zeng Qing-Luan, Zhou Tian-Mei, Ni Shi-ZHaO, Xu Guang-hong, Sun Quan-Ying, Li Zhi-Hong, Xiang Li-wen \& LAI CAI-GEN 1983. Latest Ordovician and earliest Silurian faunas from the eastern Yangtze Gorges, China with comments on Ordovician-Silurian boundary. Bulletin of Yichang
Institute of Geology and Mineral Resources, Chinese Academy of Geological Sciences 6, 129-196.

Whittington, H.B. 1955. Additional new Ordovician graptolites and a chitinozoan from Oklahoma. Journal of Paleontology 29, 837-851.

Williams, S.H. 1982. The late Ordovician graptolite fauna of the Anceps Bands at Dob's Linn, southern Scotland. Geologica et Palaeontologica 16, 29-56.

Williams, S.H. 1983. The Ordovician-Silurian Boundary graptolite fauna of Dob's Linn, southern Scotland. Palaeontology 26, 605-630.

Williams, S.H. 1987. Upper Ordovician graptolites from the $D$. complanatus Zone of the Moffat and Girvan districts and their significance for correlation. Scottish Journal of Geology 23(1), 65-92. DOI 10.1144/sjg23010065

Williams, S.H. 1988. Dob's Linn - the Ordovician-Silurian Boundary Stratotype, 17-30. In Cocks, L.R.M. \& RicKARDS, R.B. (eds) Bulletin of the British Museum (Natural History), Geology Series 43.

Ye ShaO-HUA 1978. Graptolithina, 431-486. In Palaeontological Atlas of Southwest China, Sichuan Volume, Part 1, From Sinian to Devonian. Geological Publishing House, Beijing. [in Chinese]

Zalasiewicz, J.A., Taylor, L., Rushton, W.A., Loydell, D.K., RickARDS, R.B. \& Williams, M. 2009. Graptolites in British Stratigraphy. Geological Magazine 146, 785-850. DOI 10.1017/S0016756809990434

Zalasiewicz, J.A. \& TunNicLifF, S. 1994. Uppermost Ordovician to Lower Silurian graptolite biostratigraphy of the Wye Valley, central Wales. Palaeontology 37, 695-720. 